\title{
IN PRAISE OF PRAMBANAN
}


'the real is always ahead of what we can imagine'

Paul Auster 


\author{
KONINKLIJK INSTITUUT \\ VOOR TAAL-, LAND- EN VOLKENKUNDE
}

Translation Series 26

\title{
IN PRAISE OF PRAMBANAN
}

\author{
DUTCHESSAYS ON \\ THE LORO JONGGRANG TEMPLE COMPLEX
}

Edited by

ROY E. JORDAAN

1996

KITLV Press

Leiden 
Published by:

KITLV Press

Koninklijk Instituut voor Taal-, Land- en Volkenkunde

(Royal Institute of Linguistics and Anthropology)

P.O. Box 9515

2300 RA Leiden

The Netherlands

Cover: Hans Borkent

ISBN 9067181056

(c) 1996 Koninklijk Instituut voor Taal-, Land- en Volkenkunde

No part of this publication may be reproduced or transmitted in any form or by any means, electronic or mechanical, including photocopy, recording, or any information storage and retrieval system, without permission from the copyright owner.

Printed in the Netherlands 


\section{Contents}

List of figures and photographs vii

Preface $\quad$ ix

A note on spelling and editorial details xiii

Abbreviations $\quad x v$

Partone

Roy E. Jordaan

Candi Prambanan; An updated introduction

1. Preliminary description 3

2. Name and legend 9

3. Discovery, excavation, and restoration 13

4. The location from a culture-historical perspective 19

5. Dating the temple complex: retracing its history 23

6. About the founders, art styles, and archaeological theories 25

7. The mythical Mount Meru and the churning of the ocean 45

8. Design, meaning, and sectarian sensibilities 61

9. The statues 78

10. The reliefs 88

11. General conclusions 113

Part two

\section{J.W. Uzerman}

The Prambanan temple pits

J.Ph. Vogel

The first Prambanan Rãma relief

N.J. Krom

The Prambanan statues

F.D.K. Bosch

The god Brahma surrounded by maharsi 
B. de Haan

Candi $\mathrm{A}$ and candi $\mathrm{B}$

W.F. Stutterheim

The arrangement of the Rāma reliefs of Candi Loro Jonggrang and the course of the sun

V.R. van Romondt

The reconstruction of the Siva temple at Prambanan

A.J. Bernet Kempers

Prambanan 1954

Glossary

Bibliography

Index 


\section{List of figures and photographs}

Figure 1

Figure 2

Figure 3

Figure 4

Figure 5

Figure 6

Figure 7

Figure 8

Figure 9

Figure 10

Figure 11

Figure 12

Photo 1

Photo 2

Photo 3

Photo 4

Photo 5

Photo 6

Photo $7 \mathrm{a}$ en b

Photo 8

Photo 9

Photo 10

Photo 11

Photo 12

Plan of the Loro Jonggrang temple complex

Iconographic plan of the Siva temple

Map of major temple sites on the Prambanan plain

The ruins of the Siva temple at Prambanan in the beginning of the nineteenth century

Recent drainage measures in the central temple area

OD drawing showing the geometrical centre of the temple complex

Circle diagram with the names of the lokapäla and their as yet unidentified attendants

Excavation drawings of the Siva temple by Izerman gold-foil plates found in the Śiva temple pit found in the Śiva temple pit

$$
\text { the Vișnu temple pit }
$$

Reconstruction drawing of the Śiva temple

$$
\text { central temple area }
$$

Maharși relief on the Brahmā temple 
Photo 13 The Siva temple after the rough clearing by Groneman in c. 1890

Photo 14

Javanese labourers exploring a pile of stones

Photo 15

Sorting the stones according to size and shape

Partial reconstruction of a Kāla head

Mock-up or trial reconstruction of a horizontal section of the wall of the Siva temple

Photo 18

In progress: trial reconstruction of the upper part of the Siva temple

Photo 19

The actual work of reconstruction using cranes and hoistingwinches

Photo 20

Reinforcement of a threshold

Photo 21

The scaffold used for the reconstruction of the Śiva temple 


\section{Preface}

In the years since 1988 that I have been exploring the Prambanan temple complex, I have often felt the need for an up-to-date English-language reader in which the most important results of earlier Dutch research regarding the temple complex would be presented. There were three reasons for this.

First, there were the misunderstandings and omissions that could sometimes be noted in various publications mentioning the Hindu and Buddhist temples in Central Java which were in part due to unfamiliarity with the early Dutch source material. To many non-Dutch archaeologists and art historians, Krom's (1923a) classic introduction to Hindu-Javanese art remains an almost literally closed book owing to an insufficient grasp of Dutch. As Jan Fontein (1989:10-1) has said in another context, Krom seems to have condemned his considerable achievement to obscurity by publishing in his native language, Dutch. This is of course true as well of many other Dutch publications in which Prambanan occupies a central place. One could name, for example, the reports of the Oudheidkundige Dienst (OD), the Netherlands East Indies Archaeological Service, concerning the restoration of the Śiva temple of this complex, for which the impulse was given by the Verslag van de Commissie van Advies inzake de Restauratie der Hindoe-Javaansche Monumenten (Report of the Advisory Committee on the Restoration of Hindu-Javanese Monuments) of 1926, up to and including its notice of the completion of the restoration of the Śiva temple in 1954 (Bernet Kempers 1955). Hence, even though the validity of the label 'vähana temples' was rightly called into question already in the Oudheidkundig Verslag of 1927, this label is still occasionally used by non-Dutch writers today (see, for instance, Mitchell 1977:163; Dumarçay 1986c:45; Anom 1993). Anyone acquainted with the educational facilities available to most Indonesian archaeologists and the limited opportunities for learning and practising foreign languages such as Dutch and French, will understand their frustration with this situation. These problems provided one of the reasons why senior Indonesian and Dutch archaeologists started work on a new, revised English-Indonesian edition of Krom's classic survey, a project that is still in progress. Although it is different in format, the present book on Prambanan may fit in well with this project. 
The second reason, closely related to the first one, is the possible stimulus to public interest in the temple complex that an English reader might provide. In this connection, it should be noted that by offering a reader consisting exclusively of Dutch essays I do not want to create the impression that the Dutch had a monopoly on the analysis of the monument. Not wanting to detract from the research done by other nationals, I would point out that it remains true that the Dutch were among the first Europeans to become acquainted with the monument at close quarters, and that much Dutch work had a strong influence, both in a positive and a negative sense, on our present knowledge of Prambanan. By facilitating access to earlier Dutch work, I hope to place the interested reader in a better position not only to follow the sometimes confusing course of the research that led to the things we think we know, but also, and more importantly, to understand why particular topics are not as yet well researched.

The third reason is that I hoped that with the aid of such a book I would be better able to situate my own research on Prambanan within the intellectual tradition of the discussions on ancient Central Javanese culture and society. After immersing myself in Central Javanese archaeology, I have become much more clearly aware of how much I in fact owe to the past, in this particular case to the work done by my more illustrious predecessors, even those whose views I cannot always accept and with whom I must therefore differ. In this connection, I cannot deny being rather upset by the unequal attention given to the different Javanese antiquities, due to which the Prambanan temple complex has - completely unjustly - been forced into the position of a rival to Borobudur. It would be far closer to the historical truth to regard Prambanan and Borobudur as twin pinnacles of early Central Javanese culture, a culture in which Buddhists and Hindus generally lived peacefully together and helped each other in building their respective sanctuaries.

In support of this latter contention I have included a general introduction to the Prambanan temple complex in which I have tried to take account of the latest research developments in the field of ancient Central Javanese history. Here some overlap with previous publications was unavoidable, although these earlier findings are now presented with the additions and modifications that were made necessary by the results of later research. If some passages of my text will give some readers an occasional sense of 'déjà $l u$ ', I hope they will understand that I have only reiterated those facts that are relevant to the present arguments and that are indispensable if one is to interpret them coherently.

The principal objective of this new introduction, however, is to give a systematic presentation of the material relative to Prambanan that I have collected over the past years. Much of this information was in the form of stray remarks and 
footnotes - many of them unused and forgotten - scattered over numerous prewar Dutch publications. Rather than representing a mass of now obsolete and long-discarded information, some of these data appeared to possess an astonishing degree of relevance for the discussion of basic issues that still remain to be resolved today - especially the issues of the dating of the monument and its religious background. For this reason I decided to include this long introduction as a separate part of the book. Hopefully, other researchers will find much in it that they will be able to use profitably. For the information of scholars and students, several as yet unsolved problems are pointed out and new and promising lines of inquiry are indicated.

Part II, the reader proper, presents in English translation the selected articles of or excerpts from publications by scholars who not only had a first-hand knowledge of ancient Indonesian Hindu-Buddhist art and religion, but also played a prominent role in the excavation, description, and reconstruction of the Prambanan temple complex. Three of them, namely N.J. Krom, F.D.K. Bosch, and W.F. Stutterheim, served successively as directors of the Oudheidkundige Dienst. A.J. Bernet Kempers became the first director of this Service soon after the Indonesian declaration of independence and, though he eventually returned to The Netherlands to take up another position, continued to devote the rest of his long life to the dissemination of his wide-ranging knowledge of Indonesian archaeology. J.Ph. Vogel, a renowned Indologist, wrote several enlightening studies on ancient Indian-Indonesian art-historical relations. The engineer J.W; IJzerman, a former chairman of an amateur archaeological society in Yogyakarta, played a leading part in the discovery, excavation, and description of several Hindu-Buddhist sanctuaries in Central Java, among which the discovery of the so-called 'hidden base' of Borobudur and the excavation of the temples of Prambanan are best remembered. Finally, the architects B. de Haan and V.R. van Romondt were both responsible for the meticulous planning and supervision of the actual work of reconstructing several important parts of the temple complex. The intimate knowledge of Prambanan of all these authors is reflected in the selected articles, which in my opinion are still worth reading today and are therefore made accessible to non-Dutch readers through English translations.

Now that the reader is ready, 1 am honoured to be able to thank those who have contributed especially to its materialization. I want to start with Chris van Fraassen and Madelon Djajadiningrat-Nieuwenhuis who tried to obtain funding for the project via the Dutch Indonesian Studies Program. Sadly, due to circumstances beyond their control, this program was stopped and its administrative office closed down, and the grant was not forthcoming. In the meantime, however, work on the translations had already been started. As I was reluctant to 
give up a project on which so much work had already been done, I submitted a new grant application to the Koninklijke Nederlandse Akademie van Wetenschappen (KNAW, Royal Dutch Academy of Sciences), which luckily was more successful. With a subsidy from the translation fund of this Academy, the translation of three articles could be completed. Thanks to the generosity of the translators - Rosemary Robson-McKillop and Ria van Yperen - the costs of the translation of the other articles and the updated introduction could be kept down so that they could be met from these limited funds as well. Without their help the book could not have been published. Thanks are due also to Hans Borkent for drawing the maps and illustrations, and to Marjan Groen for giving the final touches to the manuscript.

It would be almost impossible to mention all those who have helped me in this endeavour in one way or another. However, I would like to especially mention Brian E. Colless, Jaap Erkelens, Jeff van Exel, Bert van den Hoek, Annelies and Willem Hoogmoed, Willem van der Molen, Anke Niehof, Ellen Raven, Han Resink, Hans Teerlink, Hans Teeuw, Han Vermeulen, and, last but not least, Robert Wessing for their help and advice at various stages of the research and writing. Needless to say, I alone am responsible for the views expressed in my text as well as any errors that may remain in the book.

I would like to dedicate the reader to Professor Lokesh Chandra of the International Academy of Indian Culture, in New Delhi. Although I have never met Professor Chandra in person, I have corresponded with him about many aspects of the religious and political history of ancient Java since 1988. The generosity and interest shown by him were invaluable to me in my research on Prambanan and the society that made the creation of this monument possible. I wish to thank him deeply. 


\section{A note on spelling and editorial details}

Sanskrit words in this volume are transliterated according to the system used in M. Monier-Williams' A Sanskrit-English Dictionary. His spelling has been slightly adapted to the system of spelling used in recent scholarly publications, however. For consistency's sake, and in order to avoid confusion, I have standardized the spelling of Sanskrit words and names also in the translations of the works of Dutch scholars which are included in the reader at the end of this book, though not that of the Sanskrit words and names occurring in the titles of their books and articles.

The spelling of Indonesian geographical names and of the names of Indonesian Hindu-Buddhist temples is in accordance with the current Indonesian spelling system (Ejaan yang Disempurnakan), which was introduced in 1972. Thus, I have written Yogyakarta instead of Djogdjakarta, Borobudur instead of Båråbuḍur, and Candi Loro Jonggrang instead of Tjaṇdi Lårå (or Rårå) Djongrang, for example. In quotations, words between round brackets are additions of the scholar quoted, and those between square brackets are my own additions.

Authors whose names are preceded by particles such as Van, De, Le, and Von - for example, Van Blom, Le Bonheur, De Casparis, and Von Saher - are listed in the bibliography under their main name, that is, Blom, Bonheur, Casparis, and Saher respectively. I have retained the spelling of $U$ in names like IJzerman. rather than alphabetizing it as $\mathrm{Ij}$ or $\mathrm{Y}$, the latter being a separate letter altogether. Following Dutch conventions, I have rendered Oudheidkundige Dienst as 'Archaeological Service' instead of 'Archaeological Survey', as is done in India, for instance.

In order to avoid complicated editorial changes in the original format of the selected articles, it was decided in consultation with the Editorial Department of the KITLV to retain their somewhat cumbersome, old-fashioned presentation of footnotes. References that were given in an abbreviated form in the original articles are given in their complete form in the separate bibliography of Part II. Titles for which the bibliographical information was very incomplete or impossible to verify have been omitted from this bibliography. 
-978-90- $04-26042-9$ 


\section{Abbreviations}

\begin{tabular}{|c|c|}
\hline Bhk & Bhaț̣ikāvya \\
\hline HSR & Hikayat Sěri Rama \\
\hline OD & $\begin{array}{l}\text { Oudheidkundige Dienst in Nederlandsch-Indië (Archae- } \\
\text { ological Service of the Netherlands East Indies) }\end{array}$ \\
\hline OD Photographs & Photographs made by the former OD \\
\hline OJR & Old Javanese Rāmãyaṇa (Ramayana Kakawin) \\
\hline OV & Oudheidkundig Verslag (Archaeological Report of the OD) \\
\hline ROC & $\begin{array}{l}\text { Rapporten van de Commissie in Nederlandsch-Indië voor } \\
\text { Oudheidkundig Onderzoek op Java en Madoera } \\
\text { (Reports of the Netherlands East Indies Committee for } \\
\text { Archaeological Research in Java and Madura - the } \\
\text { forerunner of the OD) }\end{array}$ \\
\hline ROD & $\begin{array}{l}\text { Rapporten van de Oudheidkundige Dienst (Reports of the } \\
\text { Archaeological Service of the Netherlands East Indies) }\end{array}$ \\
\hline Skt. & Sanskrit \\
\hline Verslag Congres & Verslag Congres Oostersch Genootschap \\
\hline Verslag 1926 & $\begin{array}{l}\text { Verslag van de commissie van advies inzake de restauratic } \\
\text { der Hindoe-Javaansche monumenten, nopens de recon- } \\
\text { structie van den Çiwatempel te Prambanan (Report of } \\
\text { the Advisory Committee on the Restoration of Hindu- } \\
\text { Javanese Monuments, Concerning the Śiva Temple at } \\
\text { Prambanan) }\end{array}$ \\
\hline & Vālmīki's Rāmāyaña \\
\hline
\end{tabular}


-978-90- $04-26042-9$

Downloaded from Brill.com๑4/26/2023 02: ०3:20PM via free access 


\section{PART ONE}




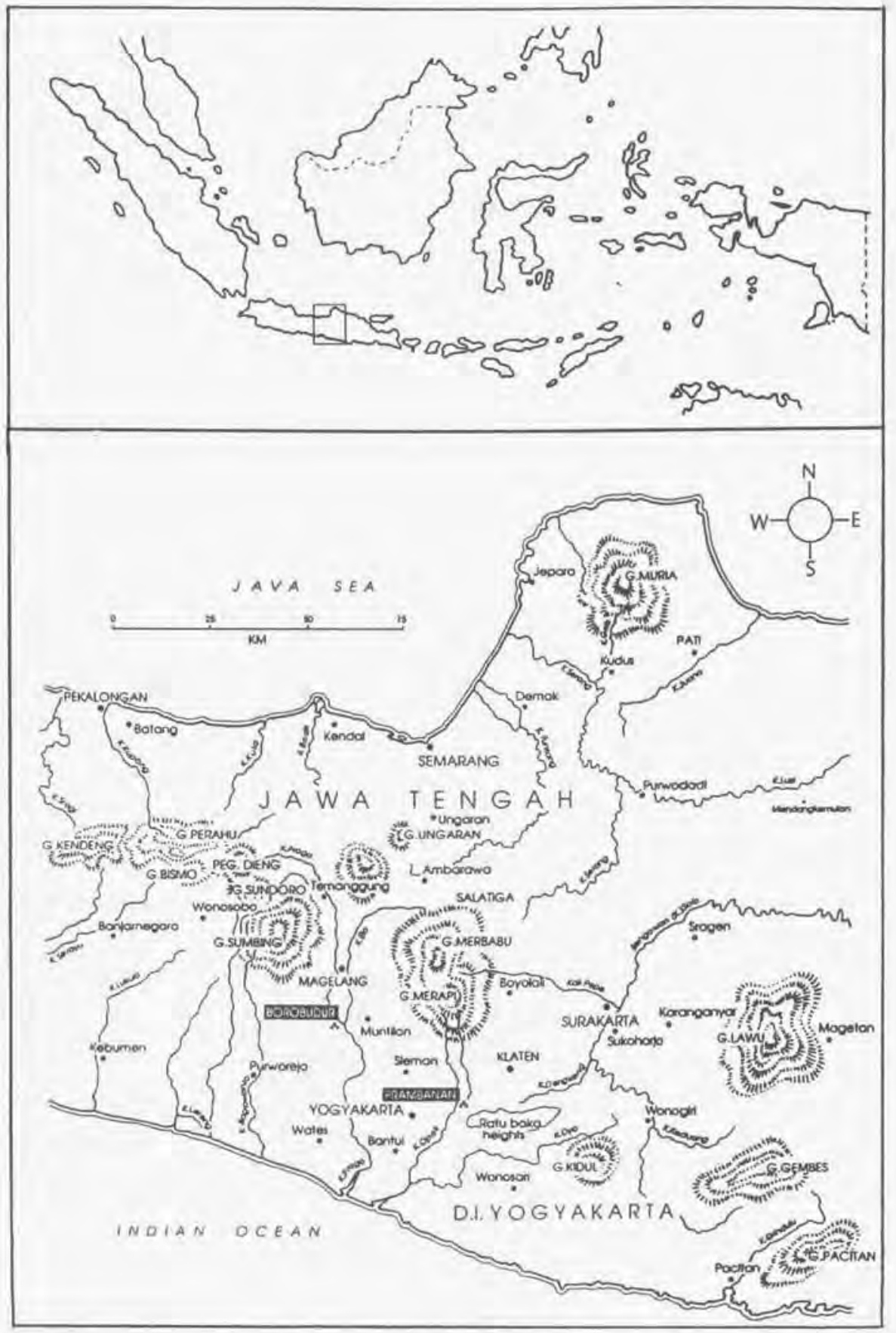

Maps of Indonesia and Central Java 


\section{ROY E. JORDAAN \\ Candi Prambanan An updated introduction}

\section{Preliminary description}

'Candi Prambanan' is the commonly used name for the largest Hindu temple complex in Indonesia. Together with the famous Borobudur, this complex forms the pinnacle of Javanese Hindu-Buddhist art. Both monuments testify to Central Java's glorious past in its so-called 'classical period', the time between approximately $\mathrm{AD} 775$ and $\mathrm{AD} 900$.

Although often compared to and mentioned in one breath with Borobudur, Prambanan is quite different, both in design and in execution. If the power and beauty of Borobudur lie especially in a large and rather massive structure, with balustrades and galleries that flow along toward the climax of the central stūpa, at Prambanan it is rather the diffuseness of the construction - its division into a large number of small temples and eight larger ones, crowned by the Śiva temple - as well as the harmonious relationship between its various parts, that comes to our notice. However, with all their external differences, there are important similarities between Borobudur and Prambanan. Most important of these are the strictly systematized architecture and ornamentation, coming forth, as Stutterheim maintained, from a similar mentality. He described this as follows:

'The powerful superstructure of Mahāyâna, the essence of which is the indivisibility and reality of the totality, rests on a broad substructure of change and illusory variations in shape. Within this world, the simultaneous materializations of the higher Buddha principles are as points of tranquillity. This is Borobudur. The Śaiva, puranic metaphysics, expressed in the subordination of the different incarnations of the High God to his supreme form [and] oriented towards mood and meaning [are] raised on a base that is analogous to that of Borobudur. [This philosophy] is a subjective expression of the reflection of phenomenal worldly experience, taught as unreal but experienced as reality. That is Prambanan.' (Stutterheim 1923:330.)

For those who have not seen the temple complex or are acquainted with it from other descriptions, I will provide a brief sketch, which will be placed in perspective and given more depth in the course of the more detailed treatments by the experts whose work is published in this volume, Visualization may further be aided by the appended plan. 

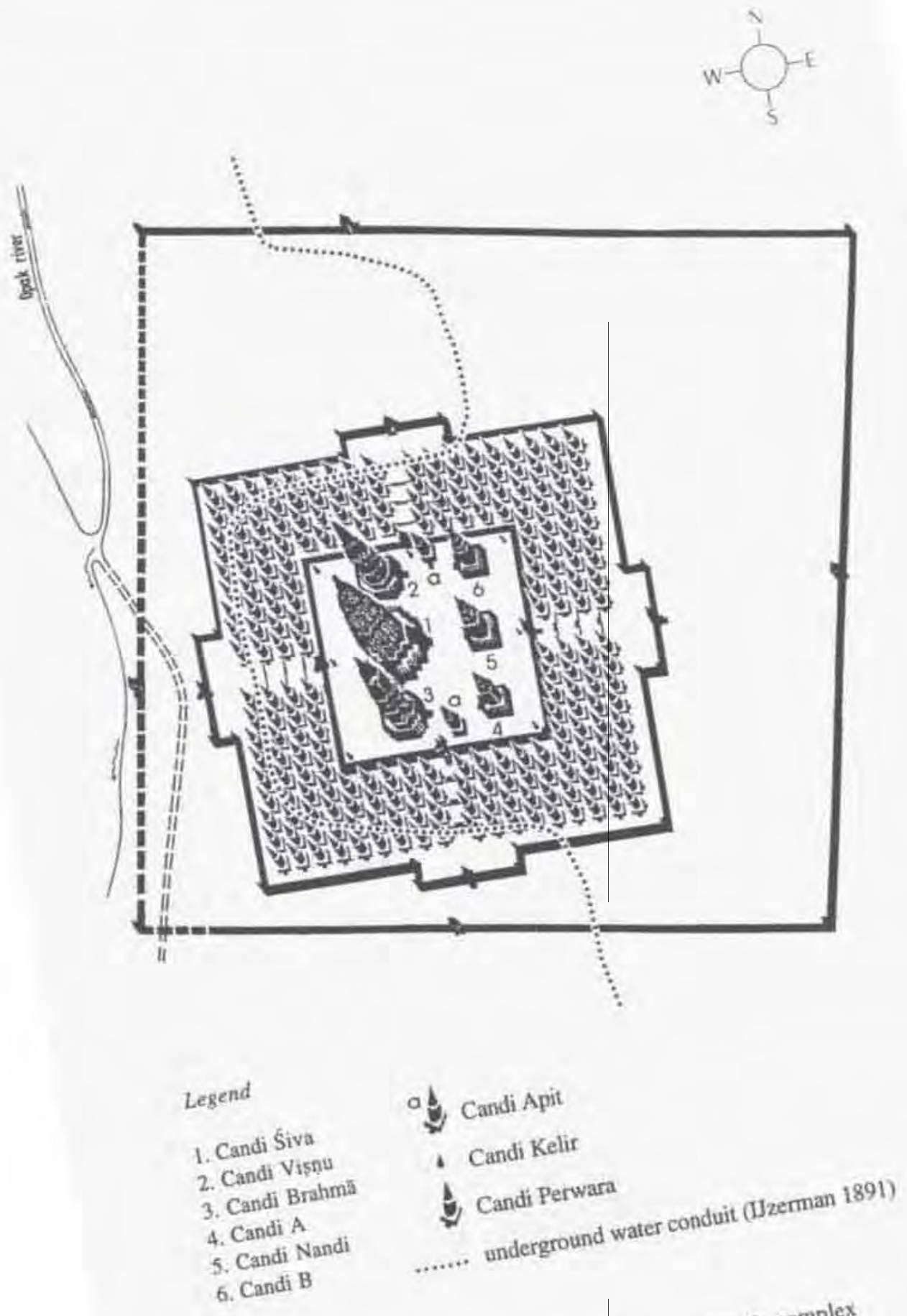

Figure 1. Plan of the Loro Jonggrang temple complex 
Prambanan is a temple complex that originally, or rather, according to its original design, comprised more than 250 larger and smaller temples. These were distributed over three areas separated by enclosing walls. The central area has the form of a raised terrace, surrounded by a massive, square wall. This wall is still more or less complete, although lacking the decorative superstructure that it may once have had. Of three of the four gateways above the stairs, only incomplete remnants remain. This wall, and the next one, which has all but disappeared, were precisely oriented to the points of the compass. In the 19th century, some remnants of a third wall used to be visible. This wall bounded the complex as a whole and separated it from the surrounding area. It did not run parallel to the first two, but was placed rather at an angle to them. The gateways, however, were placed in a straight line with those in the first and the second wall.

In addition to eight small 'turrets' (candi kelir) located along the inside of the surrounding wall, the central temple area is reserved for the large temples, arranged in a special way. To the west, facing East, stands a line of temples dedicated to the Trimūrti, the divine trio, consisting of Brahmā in the south, Śiva in the centre, and Viṣnu in the north. That the Siva temple is the main one, can be deduced from its central location, its larger dimensions $(34 \times 34 \times 47 \mathrm{~m})$, its more complicated basic form, and its more refined execution.

In the projecting part of each of the four sides of the Siva temple there is a stairway that each leads to a separate chamber or cella. The eastern stairway leads to the main chamber, in which the statue of Śiva Mahādeva stands. Its antechamber, a space that in terms of its position corresponds to the other three chambers, contains statues of Mahākāla and Nandiśvara, positioned as gatekeepers. Unlike in the other chambers, the walls in this main temple chamber are richly decorated with reliefs, consisting of among others things recalcitrant spirals and octagonal rosettes. Another noticeable difference is the absence in the inner cella of stone blocks partially projecting from the wall, which were used to place oil lamps on. This means that this deep interior temple chamber was usually wrapped in a dusky gloom.

In the southern chamber of the Siva temple stands the statue of Agastya which once used to be generally referred to as Batara Guru or Śiva Guru. In the western chamber stands the statue of Ganeśa, Siva's elephant-headed son. In the northern chamber we find the famous statue of Durgā as Mahișāsuramardinī, showing the demon she has just extracted from the slain buffalo in which he had hidden. The local people call her Loro Jonggrang.

The temple chambers mutually communicate by means of stairlandings that are connected to an ambulatory passageway running around the temple. The outer side of this passageway is bordered by a balustrade or parapet decorated 


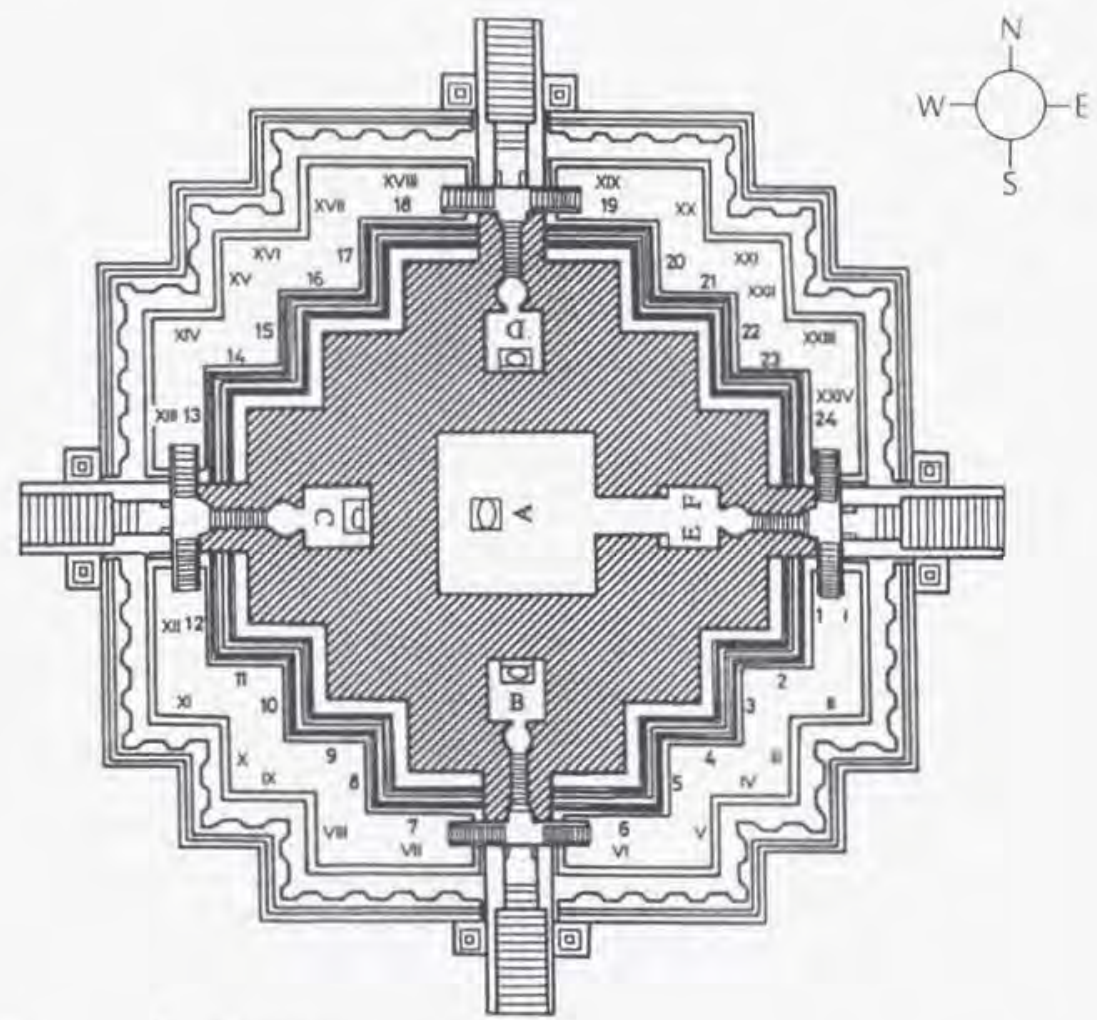

$\begin{array}{ll}\text { A } & \text { Śiva Mahādeva } \\ \text { B } & \text { Agastya } \\ \text { C } & \text { Gañeśa } \\ \text { D } & \text { Durgã } \\ \text { E-F } & \text { Nađísvara-Mahākāla } \\ \text { 1-24 } & \text { lokapāla with attendants } \\ \text { I-XXIV } & \text { Rãmãyaṇa reliefs }\end{array}$

Figure 2. Iconographic plan of the Śiva temple 
with reliefs on both sides, those on the outside showing dance scenes and musicians and those on the inside important scenes from the Rāmāyana. On the other side of this gallery, that is to say, on the temple body itself, there are reliefs of the guardians of the compass points (lokapäla) and other divinities along with their attendants.

The Brahmā and Viṣnu temples are in many respects similar to the Śiva temple, although of much smaller dimensions $(20 \times 20 \times 33 \mathrm{~m})$ and simpler in design. Thus each of them has only one temple chamber which can only be reached via a stairway in the projecting part of the eastern side of the temple. The names of these temples derive from the statues of Brahmā and Vișu that used to stand in their chambers. Both temples have an ambulatory passageway bounded by a balustrade encircling it, just like the Śiva temple. The inner side of the balustrade of the Brahman temple is decorated with reliefs which partially continue the Räma story that was begun on the Siva temple. On the other side of the ambulatory, that is, on the body of the temple, one finds reliefs of bearded priest-like figures with their attendants. Similarly, the Vișnu temple has reliefs on the temple body, depicting divinities flanked by women, and on the inside of the balustrade depicting episodes from the life of Krșna.

Across from these temples, and facing them, are three smaller buildings, also in one line. The central one of these contains a large statue of Siva's mount, the bull Nandi (Skt. Nandin), as well as two smaller statues of Sūrya and Candra, which stand against the back wall. In the past these three temples were collectively designated as candi vahana (Skt. vāhana), 'animal vehicle' temples, because it was thought that the southern and northern ones also contained an animal which served as mount each for Brahmā and Viṣnu. Acting on this assumption, Th. van Erp had a fine statue of a Garuda which had been found in a nearby village placed in the minor temple facing the Vișnu temple (Van Erp 1911). The assumption, however, turned out to be incorrect. The temples are now referred to, rather unimaginatively, as Candi B, Candi Nandi, and Candi A. Candi B and Candi A most probably originally contained a statue of Śiva Mahãyogin and a linga, a phallic object closely associated with the god Śiva, respectively (see De Haan, this volume).

In between, but well to the side of these two rows of temples, are two small shrines facing the centre; one of them is located near the southern entrance, and the other near the northern one. They are known as candi apit, apit meaning 'wedge(d) in' or 'hem(med) in' in Javanese and Indonesian (Pigeaud 1938:322; Teeuw 1990:36).

Around the central temple area, between the first wall and the lost second one, there probably stood a total of 224 small shrines, neatly arranged into four 


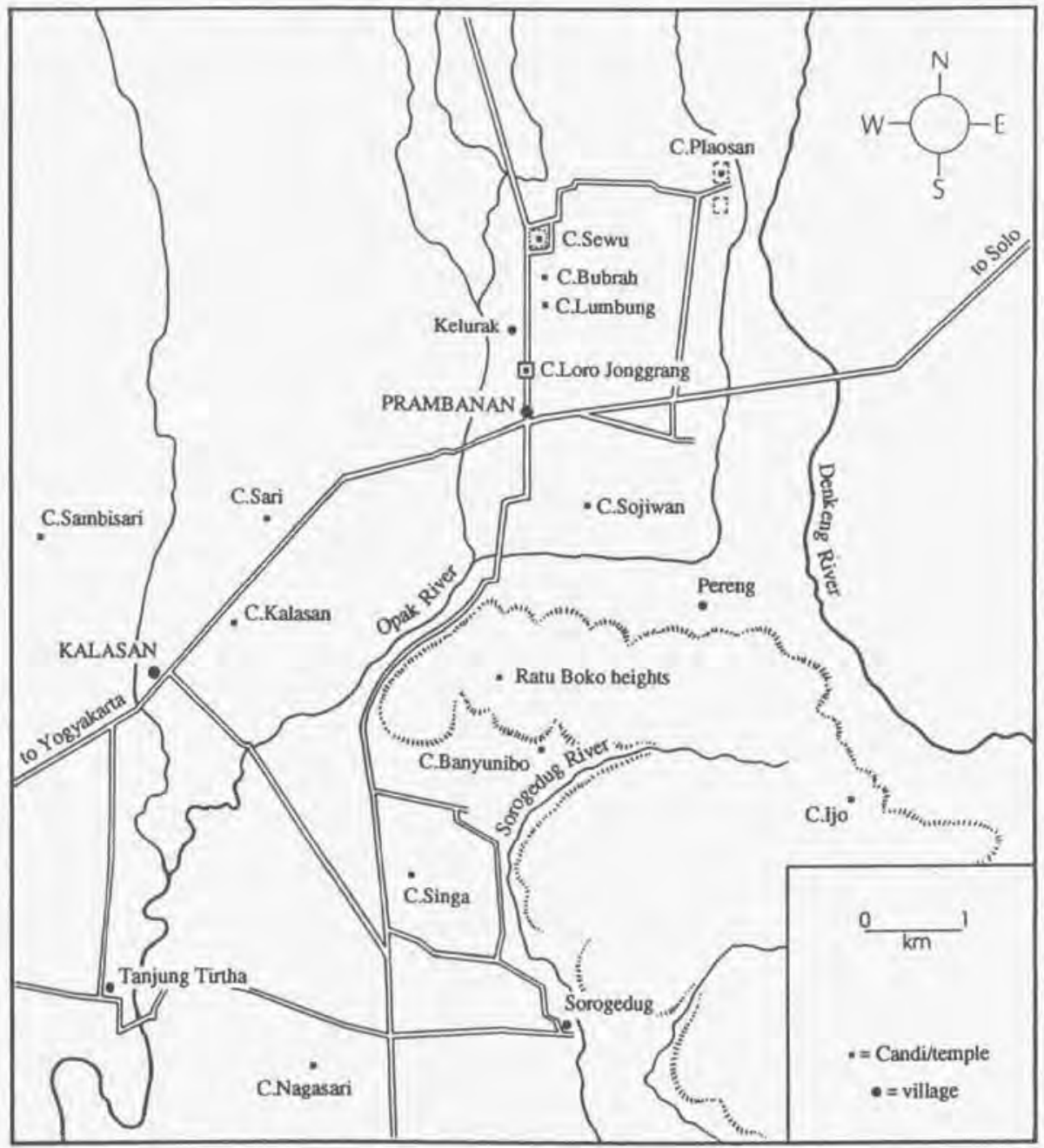

Figure 3. Map of major temple sites on the Prambanan plain 
descending tiers. From their remains it is apparent that these small subsidiary temples were all the same in size $(6 \times 6 \times 14 \mathrm{~m})$ and, although not identical, were similar both in construction and decoration. In the third area, between the lost second and third walls, no foundations have been found. It is assumed that here accommodation for priests, temple servants, and pilgrims, constructed from transitory materials, was provided.

\section{Name and legend}

In modern Indonesian, candi (or tjandi in the older spelling) means 'ancient Hindu or Buddhist temple or shrine', although, according to J. Miksic (1990:17), the word is used by the Javanese for all kinds of pre-Islamic ruins. Candi Prambanan is the most common name for the largest Hindu temple structure in Indonesia, located about 15 kilometres east of the city of Yogyakarta, in South Central Java.

The name is actually rather confusing, because Prambanan is also the name of an area, the Prambanan plain, where other antiquities are located as well. Hence the expression 'antiquities of Prambanan', which Krom subdivided into western temples (for instance, Kalasan and Sari) and eastern temples (for instance, Loro Jonggrang, Sewu, Plaosan, Sojiwan). Formerly, Prambanan was further also the name of a village to which the temple complex formally belonged.

The origin of the name Prambanan is still a mystery. If we are to believe J. Groneman (1887), there would be little use in looking for a mythological or historical meaning for it, considering the alleged fact that none of the Central Javanese temples, including Borobudur and Prambanan, has a name that refers to a god, a saint, or the form of worship to which it is dedicated. Groneman himself suggested that the name Prambanan might have been derived from the word ramban,

'to collect herbs (for domestic or medicinal purposes), [pa-ramban-an] still being the place, usually in the forest, where such herbs are sought. This explanation of the name of the ruin, which must at one time have been discovered in such a wilderness, is also given in Roorda's dictionary; [an explanation] so simple and natural, that one does not need to look for another one.' (Groneman 1887:1427.)

Groneman's rather discouraging remarks notwithstanding, it is not unlikely that the name derives from an old expression associated with the temple, and that the name of the village somehow refers to this. This possibility has given rise to a number of, in my view, rather useless etymologies. H. Helfritz (1979:111), for instance, maintained that according to an unspecified 9th-century text, the name Prambanan was derived from the village name Parawan, the inhabitants of which village had the duty to maintain the temple, in return for which the ruler 


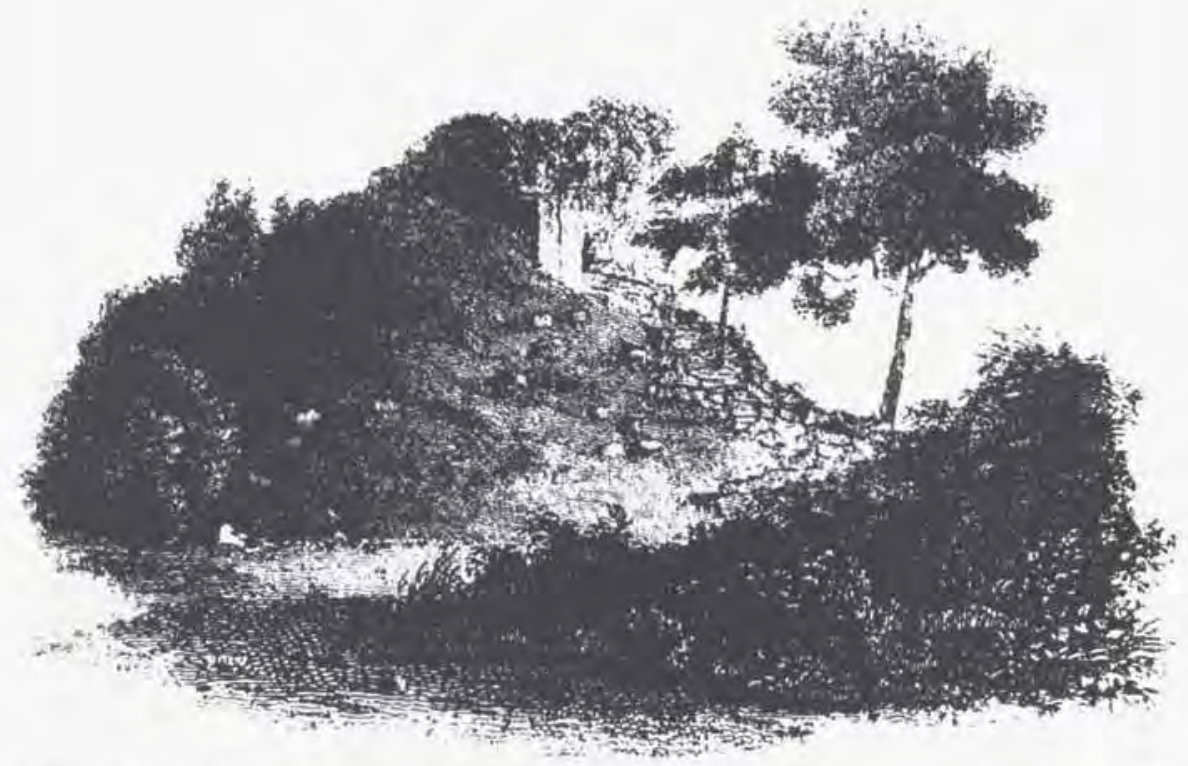

Figure 4. The ruins of the Siva temple at Prambanan in the beginning of the nineteenth century (Raffles 1817, II:11) 
exempted the village from taxation. Linguistically this explanation is unlikely, as the Javanese word parawan only means 'maiden' or 'girl'.

Equally unlikely is the explanation given by the Java scholar C.F. Winter (1839:139) who derived Prambanan, via Parambanan and Poerambanan, from (H)empoe rombo, meaning 'Rombo the smith', a smith in olden times being the most important inhabitant of a village. Winter did not discuss the perhaps fortuitous connection between such a smith and the temple, nor the fact that, if his etymology is correct, other villages named Prambanan might have existed as well. In J.F.G. Brumund (1853:52) the word hempoe is interpreted as the Javanese Vulcan' and connected with Mount Merapi; here, too, the connection with the temple complex is not discussed.

Another possibility, also mentioned by Helfritz, is the derivation of the name from the word brahmana, which was subsequently changed into brambanan and then into Prambanan. This explanation was indeed preferred by most early 19th-century English and Dutch scholars. For instance, C. Mackenzie (1814) simply wrote of 'Brambana' temples, while J. Crawfurd (1856:67) considered Prambanan to be a 'euphonic corruption of Brambanâan, which would signify "a place of Brahmins"' . This explanation is as vague as it is dubious. Although there surely were Brahmans who visited the Śaiva shrine, the translation 'place of Brahmans' gives the impression that Prambanan was a Brahman temple, in the narrow sense of the word. This is in no way certain.' Aside from demonstrable Buddhist influences (about which more will be said below), it has not been determined to date which Śaiva sect was responsible for the management of the temple complex. Keeping in mind the demonic. Tantric character of some of the archaeological finds (such as a human skeleton in the central square, which seems to be indicative of a human sacrifice), this could have been a sect like the long-lost Kāpālikas, the teachings and practices of which must have been abhorrent to orthodox Brahmans. Thus, Prambanan as a place of Brahmans is not certain. ${ }^{2}$

In Thomas Raffles' well-known History of Java (1817), on the other hand, we find a copy of an etching by $\mathbf{J}$. Mitan of a ruin of which we now know that it represented the Śaiva temple at Prambanan. The caption reads the principal

1 Personally, I would favour a derivation from the word 'parambrahma(n)', meaning 'World Spirit', 'the Absolute' (see Kern 1888:172; Zoetmulder 1982:1285), and denoting a universal place of worship, accessible to Śaivas and Buddhists alike, which comprised Candi Loro Jonggrang and Candi Sewu (see section 10).

2 Unless the Śaiva sect was that of the Păsupatas, who are known to have been occasionally referred to as 'Śiva-Brahmana' and to have worn the brahmanical cord (Bhattacharya 1961:4-5), For more information about the Păsupata and other Śaiva sects see also section 8. 
temple at Jongrangan'. In this name Jongrangan we can recognize the other, locally more popular, name for the temple complex: Loro Jonggrang, which means 'Slender Maiden', referring to the statue of Durgā that is located in the northern chamber of the central temple.

Loro Jonggrang is the leading character of a Javanese legend that runs more or less as follows.

'[A] Javanese princess called Lara Jonggrang, the only daughter of Baka, king of Mendang Kemulan, [...] was famous for her beauty and had been sought in marriage by many princes. When a prince named Bandung Bandawasa asked for her hand, king Baka said that if the young man could defeat him in battle he could have her. In the fight that broke out between the two men the king was slain. Lara Jonggrang had no intention of marrying the murderer of her father, but she was afraid to reject the young prince outright. So she told him that unless he could make a thousand temples in a single night, he could not hope to marry her.

This seemingly impossible task was nearly accomplished by Bandung because his father helped him with an army of spirits. The princess did not know what to do. At length, one of her maidens gave her wise counsel: to pound on the rice block. She did so, and the sleeping cocks of the neighbourhood, hearing the sound of incessant pounding, began to crow. Deceived into believing it was nearly dawn, the army of spirits departed, since they feared the sunlight.

The thousand temples were never finished but the prince, discovering the stratagem used against him, was enraged. He cursed the princess, causing her to become stone. But by the grace of the God Śiva she became an idol: indeed, one image in the northern niche of the big temple honouring Śiva at Prambanan has been described as that of the beautiful princess.' (Pitono Hardjowardono 1967:11-2; see also Winter 1839:459-73; Soewito Santoso 1963.)

Durgā's statue used to exercise a great attraction on the local people, as was evident from offerings of incense, rice, flowers or money (IJzerman 1891:49), as well as occasionally live goats found near it (Krom 1923a:444). Because of the help that was sought from her, she has been called the 'Notre Dame de Bon Secours' of Prambanan (Scheltema 1912:90). Her attraction is also evidenced by the shining breasts and waist of the statue, caused by the loving touch of the numerous worshippers. Some early foreign visitors, who were hardly able to enter the chamber because of all the rubble there, were reminded of a metal breast plate or a metal statue by the sheen on the stone (Oudheidkundig Verslag 1920:105-6).

Although Krom (1923a:443), for clarity's sake, preferred the local name Candi Loro Jonggrang, his example was not widely followed, and the name Candi Prambanan is still preferred, especially among foreigners. Here, depending on the context, I will use the two names interchangeably. 


\section{Discovery, excavation, and restoration}

It is not easy to determine who discovered Loro Jonggrang. An obvious candidate for this honour would be Raffles, Lieutenant-Governor of Java during the British Interregnum (1811-1816). Raffles took a serious interest in Central Javanese temple ruins, which he had explored and described by his assistants, C. Mackenzie and G. Baker. As was noted above, the first sketch of the ruin of Loro Jonggrang is found in Raffles' book later recognized as a Śaiva sanctuary by Raffles' compatriot, Crawfurd.

Those with a more formal penchant will mention C.A. Lons in this connection. Lons was an employee of the Dutch East Indies Company who in 1733 , while staying at the court of the Javanese sultan as a member of an embassy made a sightseeing tour of a number of temple ruins and reported on these to his superiors. Although it is possible to recognize some statues of Durgã and Ganeśa from his descriptions, the question is whether Loro Jonggrang was recognized as a separate temple at that time. As is rightly observed by Bernet Kempers (1978:100), mention was made in those days of 'Brahminic sanctuaries', without further specification. Furthermore, the compactly grouped temples were so overgrown with vegetation that, as Lons pointed out, 'they looked more like mountains than like chapels [temples]', and that for this reason he was not able to inspect the other large temples (Lons as cited in Leemans 1855:11). The remainder of his descriptions is indeed so vague that it is impossible to tell whether it still concerns Loro Jonggrang or has shifted to the neighbouring Sewu temple. This indeterminacy makes it impossible to say whether the giant statues of doorkeepers (dvärapäla), which Lons reported having seen were those from Candi Sewu or were the ones from Loro Jonggrang which have long since disappeared (Bosboom 1903). That Candi Prambanan must have had a number of dvärapāla is evident from the mention of 'fierce doorkeepers' in the Loro Jonggrang inscription edited and translated by J.G. de Casparis (1956:322).

H.C. Cornelius, who in about 1805 had begun charting a number of antiquities on the Prambanan plain, did not describe Loro Jonggrang separately, either, in contrast with the nearby Sewu and Kalasan temples, of which he left a ground-plan and a reconstruction plan (Bernet Kempers 1978:40-1, 101). The 'Views of Brambana' that Cornelius made later were commissioned by Mackenzie (Bastin 1953:275).

It is perhaps best to leave the question of the discovery for what it is. We should not forget that for the local populace there is nothing or little to be discovered about a ruin that, as far as they are concerned, has been there since time immemorial and about which countless stories and legends are told. As a 
matter of fact, if we must speak of 'discovery' at all, the honour should perhaps be given to the East Javanese court poet Mpu Tanakun, who travelled from Tumapel (Singosari) to the interior of Central Java in the 15th century. He has left a short description of his travels, which begins with the wonderful words 'A great temple complex from ancient time rose near a mountain stream, and the path there was lonely'. In the remainder of his poetic description of this temple complex there are so many correspondences with Loro Jonggrang, that an identification as such cannot be ruled out (Jordaan 1991b).

Whoever had the honour of being the (re)discoverer, it is indisputable that Dutch scholarly interest in the archaeology of Central Java was strongly stimulated by Raffles' and Crawfurd's pioneering work. This scholarly interest in the main relied on the supposition of Raffles and his assistants that Loro Jonggrang was a Buddhist sanctuary, like most of the temples in the Prambanan area.

It is not surprising that the understanding of these pioneers remained restricted as long as the Loro Jonggrang ruin was overgrown with vegetation. The clearing of the grounds and the start in 1885 of the excavation of the site of the temple complex were the work of the engineer J.W. IJzerman, then chairman of the local amateur archaeological association. His efforts seemed to confirm that Loro Jonggrang was a Śaiva temple and not a Buddhist shrine. Although Uzerman's excavations represented an important breakthrough in the study of the temple complex, his method was not as careful as it was later alleged to have been. Judged by current scholarly standards, it was actually quite rough, and one would have to say that his results were achieved at the cost of much important and irretrievable information. Take, for instance, the human skeleton in the central temple area, about which IJzerman wondered if it pointed to a deliberate burial, an accident, a crime, or perhaps even a human sacrifice. Regrettably he neither noted the exact positioning of the skeleton, nor had it forensically examined to determine the sex and the probable age of the victim or the probable cause of death, natural or otherwise.

While Uzerman's negligence is regrettable, the work of his successor, Groneman, was a disaster. His excavations were hardly more than a rough clearing of the area, although one preferred to use the euphemistic term 'deblayering' (from the French déblayer, 'to clear or sweep away') for this in those days. In the process,

'some pieces of heads and ornamental pieces that were found were sorted out and placed in neat rows. All other stone blocks, decorated as well as plain, were dragged away and thrown in a heap in the gorge to the west of the temple area. As no notes were kept of the location of the various pieces that were found, a wealth of data on the original structure and the ornamentation of the main and auxiliary temples was lost'. (Verslag 1926:22; see also Van Erp 1909:168.) 
For the sake of clarity it should be explained that 'the gorge to the west' was the steep bank of the Opak river. According to Groneman (1893:4) there was 'ample opportunity for the disposal of the rubble in the area sloping down to the Opak'. How much was lost in the river in this way, including significant fragments of reliefs and broken parts of statues, cannot even be guessed at. It is not surprising to learn that several early scholars considered the loss of information so enormous that even a reconstruction on paper in their yiew was now an impossibility. This led J. Brandes to pronounce his now famous characterization of Groneman's efforts as 'a large-scale archaeological slaughter'. As a member of the board of the archaeological society. Groneman was also involved in the decision by the government of the Netherlands East Indies to comply with the urgent request by the king of Siam, Chulalongkorn II, to be allowed to take home some reliefs and statues from well-known Hindu-Buddhist sanctuaries as souvenirs of His Majesty's visit to Java in 1896. Assuming that several examples existed of the chosen archaeological items, and that they therefore would hardly be missed, the king was allowed to remove no less than eight ox-carts of statues and reliefs to Siam. Among these were a number of unique Buddha statues from Borobudur and several reliefs from Prambanan. Especially thanks to the diplomatic efforts of P.V. van Stein Callenfels and G. Coedès, two Rāma reliefs from the Brahmā temple and a Kṛșna relief belonging to the Vișn temple were later returned to be eventually replaced in their proper positions in the planned reconstruction of the temple complex. ${ }^{3}$ The Buddha statues, however, were never returned, as they had quickly become objects of worship for the Thai people. (For more information about this affair, see Van Erp 1917, 1923, and 1927.) However, it would be an injustice to hold Groneman solely responsible for the damage. There were, in Van Erp's words, other 'mutilating hands', namely of Javanese villagers who dragged away stones to be used as thresholds or foundations for their houses and those for all manner of other purposes. Westerners, like the administrators of large plantations, also used stones for waterways, culverts, dams, and foundations. According to Van Erp,

the Dutch East Indies Railway Company had a share in this as well. When at the beginning of this century the company tore down its old stations and train stops and replaced them with fine new buildings, we noted to our dismay that within the plastered walls of the old Prambanan stop not only ornamented stones but also some large stone slabs with exquisite carvings had been used. They had been dragged away

3 According to Jan Fontein (personal communication) the objects were not just returned, but exchanged for a sculptured fragment that had been recently excavated in situ and that had turned out to be a part of the Ganesa from Singosari in the Bangkok Museum. It seems that F.D.K. Bosch was instrumental in the exchange. 
from the nearly inexhaustible "Fundgrube" of the Loro Jonggrang complex, located a few hundred metres away.' (Van Erp 1943c:190; see also Krom 1923a, I:446.)

Luckily the situation was not as fatal as had been suspected. Later architects and their Javanese assistants, thanks to their sharp eyes and their infinite patience, were able to create a more authentic order in the mass of rock left behind by Groneman. They were so successful in this, indeed, that an experimental partial reconstruction could be attempted, both on paper and in practice. In doing so they went beyond the stage of purely 'consolidating repairs', measures to prevent further deterioration, to which the Oudheidkundige Dienst had restricted itself up to then. Under the direction of F.D.K. Bosch, who had just taken up the post of director of the Oudheidkundige Dienst, the architect P.J. Perquin in 1918 started on repairs to the lower part of the Śiva temple. According to Bernet Kempers (1978:102), the leaning corners were pulled down and straightened or reinforced, while the water supply(?) was improved as well. This was followed by the reconstruction of the eight small corner 'turrets' (Dutch: hoektorentjes) located on either side of the four stairs of the main temple, two of which were reconstructed from the original fragments. The other six turrets were reconstructed out of new materials, on the model of the first two. Next came the reconstruction of the balustrade around the ambulatory. with dance scenes on its outer face.

This physical reconstruction was not easy, nor free from errors. In this early phase, the executing architect might consider it more important to rebuild certain parts than to recover the system underlying the original construction, as for example in the case of the reliefs with dancing scenes. These and other matters became apparent in 1920, giving rise to the so-called 'Restauratiekwestie' (restoration issue) which dragged on for some years, and of which Bernet Kempers (1978:107-12) has written a brief summary.

An official committee was formed to advise the authorities on the restoration of Hindu-Javanese monuments and to look into the desirability and feasibility of reconstructing the Śiva temple at Prambanan. In spite of several disagreements and the departure of a few of its members, the committee produced a substantial report (Verslag 1926). This showed the majority of its members to be in favour of reconstruction rather than consolidation or preservation of the temple ruins in the state in which they had been found. This did not mean that the earlier mistakes were ignored, however. In order to prevent a repetition of these, the advisory committee clarified the procedures to be followed in the reconstruction. Thanks to these guidelines, the way was now clear for a complete reconstruction of the Śiva temple at Prambanan (see also Bernet Kempers, this volume). 
As Bernet Kempers (1978) writes, the reconstruction work often met with all kinds of delays. To begin with, the newly appointed young architect, De Haan, had to spend months checking the work done by his predecessor, who had been transferred, and correcting this where possible. After that he occupied himself with the reconstruction of the Brahmä temple and the two so-called 'court' temples (candi apit). The work was not made any easier by various budget cuts and the worldwide recession of the 1930's. Tragically, De Haan died in 1930, just before the completion of the reconstruction of the 'court' temples, between 1932 and 1933.

Van Romondt, De Haan's successor, had to contend with the same budgetary restrictions, and it was not until 1937 that the final reconstruction of the Siva temple was started, with money from a special fund. This project had been scheduled to take seven years.

The completion of the work was delayed by the Second World War, followed by the Indonesian struggle for independence. ${ }^{4}$ Thus the reconstruction of the main temple, which had been in progress since 1918, was only completed in 1953, under a new national flag. The inauguration ceremonies were conducted by Soekarno, Indonesia's first president.

Owing to all kinds of circumstances, the reconstruction of the rest of the temple complex also experienced numerous delays, though due to the absence of written documentation, the course of events is difficult to retrace. Kempers (1978:171) reports that after the war, two of the 224 subsidiary temples located between the first and the second enclosing walls were rebuilt. Mock-ups or trial reconstructions of the Brahmā and Śiva temples seem to have been largely ready in 1944. In 1978 Bernet Kempers expressed the belief that, 'owing to other activities of the Service, reconstruction will probably not receive priority'.

Meanwhile both the Brahmā and the Vișnu temples have now been reconstructed. The Viṣnu temple, the last of the Trimūrti temples, was inaugurated by President Soeharto in 1991, as we are informed by the plaque near the new Garuda statue that was installed next to the main entrance for the occasion. The reconstruction of the remaining temples, namely the so-called Nandi temple, Candi $\mathrm{A}$, and Candi B in the central temple area was recently completed.

I do not know whether in the reconstruction of these temples the guidelines

4 According to the Oudheidkundig Verslag of 1941-1947, the report only to appear in 1949, the Japanese had continued the work of reconstruction until the supply of cement and other building materials was disrupted by their own war effort.

5 In a recent Indonesian publication (Anom 1993:2), it was reported that reconstruction of the Brahma temple was started in 1978 and finished in 1987, while the work on the Viṣnu temple took about nine year to be completed (1982-1991). The reconstruction of the misnamed vāhana temples was begun in 1991 and completed in 994. 
laid down by the colonial advisory committee were followed completely, but this seems doubtful. During a recent stay in Indonesia I was often amazed by the presence at the temple of labourers chiselling stone, something I found difficult to reconcile with the demands of an authentic reconstruction. It is difficult to tell whether this is a new development or whether this is a practice that is still in accordance with the guidelines laid down by the colonial advisory committee. Indeed, the Verslag (1926:18) states 'that the committee would be pleased to see experiments carried out to determine to what degree the present tukangs [craftsmen] are able to reconstruct the profiles, the ornaments and the sculptures, albeit in a descriptive form'. With reference to Photo 1 , which shows a relief of Śiva just below the huge Kāla monster's head, it is impossible to tell if the figure of the celestial being that is suspended on a cloud above Siva's right shoulder is an example of such a partial, descriptive mode of chiselling or if it is to be considered as proof that the relief was never finished. ${ }^{6}$

One incontrovertible indication that the reconstruction of the femple complex is not being carried out in accordance with the old rules was the deliberate destruction of a small part of the first inner wall, in connection with the improvement of the drainage of the central temple area. For this purpose shallow channels were dug which ended at the recently made hole in the wall. Later (in 1993) these were replaced with concrete drainage channels and several large collecting tanks. However understandable these drainage measures may be, they are open to severe criticism. Not because these measures are contrary to rules laid down in colonial times, which were not followed either in the case of the vaults of the Śiva temple, which were deliberately made from poured concrete, but because they seem not well thought out and disregard the original design and probable intentions of the Hindu-Javanese architects. A rediscovery of the idea underlying the original construction had been the guiding principle of the recommendations of the advisory committee. In a number of recent publications I have tried to demonstrate that the poor drainage of the central temple area is not due to a possible error in the construction by the original builders, but seems rather to form part of their original plan, involving the construction of an artificial tank or pond. As this is not the place to discuss this hypothesis in detail, I will return to this matter in the discussion of the mythological background of the design and the purpose of the builders (see section 7).

6 To indicate the use of a new stone, the former Oudheidkundige Dienst would have attached a small lead seal to the stone, which I was not able to detect on the stone in question. For the past few years, the Indonesian Archaeological Service has been inserting epoxy resin into small, specially drilled holes in any new stone as a substitute for these lead seals (Soenarto 1991:29). 


\section{The location from a culture-historical perspective}

As was pointed out above, the Loro Jonggrang temple complex is located in the village of Prambanan (now Bokoharjo), east of the city of Yogyakarta, on the main road between Yogyakarta and Surakarta. Coming from Yogyakarta, the temple complex lies on the opposite side of the Opak river, whose source is on Mount Merapi and which eventually flows into the Indian Ocean. This simple fact immediately gives rise to a number of questions about the Javanese who built the temple and used it for their daily worship.

Was their settlement also located on the eastern side of the river? This seems probable, considering the fact that the Opak, especially during the rainy season, must have been a formidable and dangerous obstacle to be crossed (IJzerman 1891:38; Krom 1923a, I:254). Furthermore, the fact that the main entrance of the temple is located on the eastern side, apart from having religious and symbolic significance, could indicate the location of a settlement in this direction. Considering the grand dimensions of the temple complex, it is furthermore not ruled out that it was an important settlement, perhaps even the centre of the Javanese state, where the kraton, the ruler's court, was also located. However, it is not clear where the palace was, although one may make some conjectures.

\section{Temple and kraton}

Before discussing these conjectures, we must note that the question of the location of the early Central Javanese kraton is a subject that has long been debated by archaeologists and historians. Originally they believed the temple and the kraton to be close to each other. Krom was inclined to view Loro Jonggrang as a state temple and believed the construction of a temple of such dimensions, design and execution to be 'only possible in the centre of a flourishing and powerful state [and] not in an arbitrary city' (Krom 1931b:171). He was opposed to the terms 'temple city' and 'priests' settlement', used by M. Lulius van Goor $(1919: 3,1929)$ and others, because of their implication that Prambanan was a sacred place which was occupied solely by priests and monks, an occasional pilgrim aside. 'On the contrary', Krom continued, 'one has to imagine the bustling activity of a large urban population among these temples, with all the industry, commerce, and trade connected with this' (Krom 1923a, I:254). Krom spoke of this capital as 'a large city', consisting of a number of distinct quarters. ${ }^{7}$ Following J.C. van Eerde, he wondered if 'the number of

7 Recently, Bennet Bronson (1977) argued that the Prambanan site must have had 'several tens of thousands of inhabitants' rather than being a ceremonial center that was populated solely by priests, administrators, and servants. Typifying Prambanan as a landlocked 
subsidiary temples at Loro Jonggrang did not coincide with the number of wards, each was supposed to look after its own temple and the offers to the godhead whose seat it was, a servant of the Supreme Deity' (Krom 1923a, I:453; see also Van Eerde 1911:22).

The western ward, with the Kalasan temple as its focus, was believed to be older and connected with the foreign Śailendra dynasty, who allegedly had their kraton on the more southerly Ratu Boko plateau. After the expulsion of the Śailendras in the second half of the 9th century, the city was believed to have been expanded in an easterly direction and the construction of the Loro Jonggrang temple complex begun. Krom suggested that the new rulers of the state of Mataram, who had regained their power from their base in East Java, also had their kraton in Prambanan, though not at Ratu Boko, which had been abandoned by the Śailendras. This kraton, however, was moved to East Java during the first half of the tenth century, owing to some calamity, such as a volcanic eruption or an epidemic (Krom 1923a, I:440-1; 1923b:83).

Stutterheim, on the other hand, gradually dissociated himself from the popular view that the location of the kraton should be sought in the interior. He did not think it probable that a kraton would have been located on the Ratu Boko plateau; it seemed to him a more likely place for a religious sanctuary with hermitages (Stutterheim 1926a). Partially on the basis of tenacious Javanese folk traditions, which connected the legendary capital, called Mendang, with Mendang Kamulan in Grobogan near Semarang (see Map), he began to consider a location on the north coast of Java (Stutterheim 1929b:19). His suspicion that the early Central Javanese kraton was probably located there, near ports and trade routes, was strengthened when he began to think of the Javanese temple in the light of his funerary theory, considering candi as places of internment or mausoleums for one or more deceased rulers. As a result, the interior, where most of the large temples are located, was regarded as an area reserved for gods (whom he considered as no more than deified Javanese ancestors), in contrast to the coast, the domain of people (Stutterheim 1932:27882). Furthermore, Stutterheim thought in terms of only one kraton, because in his view the old state of Mataram had been ruled by only one dynasty, the Śailendras, some of whom had converted to Buddhism in the 8th century.

Stutterheim's ideas were not without a certain influence. Concerning the Jocation of the kraton, Krom admitted in a first reaction that the possibility could not be ignored that Mendang Kamulan had been an interim location for the kraton during its transfer from Central to East Java. He did not, however, feel 
that the tradition that the new kraton was moved to Mendang from Prambanan, as noted by Raffles, was contrary to his view that the old kraton should be sought at or near Prambanan, though not on the Ratu Boko plateau, which he continued to connect with the expelled Śailendra dynasty, in spite of Stutterheim's observations, but somewhat further to the east. Krom did not even want to exclude the possibility that Mataram might have had more than one kraton, as long as it remained impossible to determine if the cryptic term 'Poh Pitu' (seven Poh), found in connection with Mendang, referred to kraton belonging to seven successive rulers (Krom 1931:168-71).

Stutterheim's ideas initially seemed to be supported by the results of archaeological explorations in the area of Prambanan and Sorogedug. 'Ceramics and potsherds systematically collected there in 1939 and 1940 originated from the same period as the monuments but, including no household articles, did not indicate the presence of dwellings' (Soekmono 1967:4). Although the resumption of the excavations in the Grobogan area on the north coast right after the war considerably strengthened the possibilities of the idea of the kraton having been located there, not all archaeologists were convinced of this. This was especially because of doubts about the validity of the funerary theory that underlay the idea.

Only with the gradual decline in popularity of the funerary theory after the Second World War (Bosch 1954; O'Connor 1966; Soekmono 1974) could the question of the meaning of the temple and the Central Javanese kraton be raised as separate but related entities. Bosch simply asserted that the kraton (which word he uses in the singular) had never been anywhere but in the interior, saying:

'And it is again in the interior, in the almost inaccessible plains of Kedu and Prambanan, on all sides enclosed by volcanoes, that, during the flourishing period of Central Java, the royal residence is to be found' (Bosch 1961b:10).

He was non-committal about the question of exactly where the royal residence had been located, nor did Bernet Kempers commit himself on this point, positing that:

In Central Java we have no certainty about the places where settlements were located. One is inclined to think of the Prambanan area with its many temples - though do such royal "monuments" properly belong with a city? - as well as of the north coast, where there must in any case have been trade settlements [...]. A unique example of an area full of ruins, in which one can at least recognize mostly traces of a royal residence, is the Ratu Boko plateau [...].' (Bernet Kempers 1978:20-1.)

Yet, one page further down Bernet Kempers admits that Ratu Boko is a somewhat impractical location for a kraton and thus wonders if it might not have been a royal pleasure garden, like the later Sultan's pasanggrahan. 
It is perhaps worth noting that Bernet Kempers does not say anything about the royal dynasty that used the Ratu Boko complex as either a palace or a playground. This silence is even more remarkable in the light of the new ideas about Ratu Boko that had meanwhile been put forward by De Casparis, whose PhD supervisor (promotor) he had been. On the basis of his epigraphical research, De Casparis (1956:255) had come to the conclusion that the Ratu Boko plateau had earlier been known as Walaing. Just like Krom, De Casparis was convinced that there was a close relationship of the area with the Buddhist Śailendra dynasty, although he avoided the word kraton.

According to De Casparis, the Ratu Boko plateau was the place where in 855 the final battle was fought between the cornered Śailendras and a Javanese Śaiva ruler approaching ever closer from the north. The victorious Śaiva ruler allegedly not only raised a few linga shrines on Ratu Boko as symbols of his victory, but also built one of his residences there (De Casparis 1956:343). In a later publication De Casparis (1964) showed, on the basis of new information derived from inscriptions, that a renowned Buddhist monastery was probably located on the Ratu Boko plateau, and that this monastery must have maintained close ties with the Abhayagiri order in Sri Lanka (see also Lokesh Chandra 1986).

That there nevertheless was a Śailendra kraton near the Prambanan temples (as well as the monastery on Ratu Boko) can be deduced from a Chinese report of the journey of a Burmese embassy to Java in around $800 \mathrm{AD}$, the importance of which for the reconstruction of early Indonesian history was clearly realized by Brian E. Colless (1970). From the brief description of the journey of the Burmese in Java, it can be concluded that in the interior ('beyond two large mountains', which Colless identified as Mount Merbabu and Mount Merapi) lay a kingdom, 'the ruler of which called himself mahāräja'. It is almost certain that a Śailendra ruler was meant here, not so much because the Śailendras had a special preference for the title mahäräja (Coedès 1934:68, 1959:46), but primarily in view of the information that in this Central Javanese kingdom 'the same customs' were observed as in Śrivijaya, the famous Mahāyāna Buddhist kingdom in South Sumatra, which the Burmese had visited at the beginning of their journey.

In contradiction with Bosch's exaggerated claim about the isolated geographical position of Central Java, cited earlier, the Burmese reported that another kingdom was located only a few days' travel away. This state was called Shep'o, in other words, Java, or, as Colless proposed on the basis of later Chinese evidence, 'the city of Java'. It was located on the north coast of Java, which was most probably the long-sought site of Mendang in the Grobogan area. For Colless this information supports the theory that there were two 
rival dynasties in old Central Java, namely the Śailendras of Wailang (Ho-ling) and a Javanese dynasty, which Colless, following De Casparis, calls the Sañjayas.

This is not the place to explore either the complicated question as to whether there were one or two or even more rival dynasties in ancient Central Java, or regarding the still unclear relationship between the Śailendras and the rulers of the kingdom of Śrivijaya in South Sumatra. With regard to the location of a kraton near Prambanan, the only thing that can be mentioned in addition is the two recent finds in Wonoboyo, a village five kilometres to the east of the Prambanan temples, in late 1990 and 1991, of a large cache comprising several kilograms of gold and silver ornaments and non-ritual utensils dating from the 9 th or 10th century. These are a strong indication of the presence of a kraton (Kompas 1990a, 1990b; Temu 1993; Wahyono Martowikrido 1994). It still has to be determined to which dynasty this treasure belonged, but engravings of scenes from the Rämãyana on some of the items according to some Indonesian archaeologists suggests a relationship with Candi Prambanan, where episodes from the same epic are depicted on the Siva and Brahmā temples.

\section{Dating the temple complex: retracing its history}

Until recently an exact dating of Loro Jonggrang was hardly possible, owing to the absence of a founding charter. Only tentative datings existed, which were pushed ever further back in time. While in Crawfurd's opinion (1820a:361-2, 1856:68) the Prambanan temples, to the east of the Opak, were 'not of a very remote antiquity' and could not be dated any earlier than the 12th or 13th century, most subsequent scholars have thought of a founding date somewhere in the second half of the 9th century or the beginning of the 10th century - that is to say, in the period between the expulsion of the Buddhist Sailendras and the transfer of the seat of government from Central to East Java.

Some have considered this transfer, which was assumed to be due to some kind of calamity, an acceptable explanation of the fact that the temple complex was not completed. This incomplete state was deduced from the lack of ornamentation on the first inner wall and, it was said, on some of the buildings (Lulius van Goor 1919:4; Soehamir 1948:6). Krom was somewhat more ambivalent about this. He also placed the latest phase of construction in the last years of Central Java's florescence, which met a catastrophic end, as was to become evident from the lack of ritual deposits in some temple pits, in which ashes and other materials (to be discussed later) were found. He also pointed out, however, 
that many East Javanese temples were never finished (Krom 1923a, I:441, $1923 \mathrm{~b}: 1-32){ }^{8}$

Only after the Second World War was the foundation of the temple dated by the epigrapher De Casparis (1956:280-330) in the second half of the 9th century, on the basis of a translation of a metrical Old Javanese inscription dated $856 \mathrm{AD}$. This stone inscription was at first listed in the catalogue of the National Museum in Jakarta as D28, but is also known as the Sivagrha inscription (Damais 1952:30), while for clarity's sake I shall call it the Loro Jonggrang inscription. Although the inscription only mentions the inauguration of a Śivagrha, literally 'House of Śiva', De Casparis convincingly demonstrated that the description of the temple given there could equally well refer to the Loro Jonggrang temple complex. This identification is now generally accepted. Without casting doubt on this identification, another interpretation of the inscription seems possible, forcing us to push the date of the foundation of the temple complex even further back, from the second half to the beginning of the 9th century or probably even to the 8th century AD (Jordaan 1993).

Which of these latter two datings is to be preferred depends on the correct reading of the inscription. It is certain in any case that it does not report that the construction of the temple complex was only started in $856 \mathrm{AD}$. On the contrary, one gets the definite impression that construction was well under way at that time. The same idea seems to have occurred to C. Holt (1967:54), judging by her statement that ' $[t]$ here are some indications, however, that the temple complex or at least its nucleus may have been built even earlier:. ${ }^{4}$ My enumeration of the so-called 'curious correspondences', noted by De Casparis, between the description of the temple in the Loro Jonggrang inscription and the actual complex included not only the Sivagrha, the 'House of Śiva' (which may equally well be interpreted as the plural 'Houses of Śiva'), but also the dam-like wall (tamwak) surrounding the central square, the pavilion-like buildings near gateways, and the (rows of) subsidiary temples, which are designated as 'votive buildings' (anumoda gawai) (Jordaan 1991a). It is superfluous to point out that

\& Concerning the deliberate state of incompleteness of most Hindu-Javanese sanctuaries, Bosch (1920:164 n.5) following Aymonier, wondered whether one should perhaps think of a possible connection between this and certain ideas about the consequences of the completion for the royal patron. Completion of a meritorious work might well shorten the patron's life, or, conversely, extending the work could lengthen it or enhance the king's opportunities for increasing his merit.

9 In similar vein, Damais writes that there is a strong likekihood that the Prambanan complex was inaugurated in November 856 AD' (Damais 1968:487). Bennet Bronson (1977:258, table 14.1) quite accurately fixes the period of florescence of the Prambanan site between $A D 675$ and $A D 1000$, which he incorrectly understood to be the approximate consensus of current research, however. 
all these components could not have been built between 855 and 856 , the period between the expulsion of the Śailendras from Java and the inauguration of the temple complex a year later. Even if the inauguration involved only the main temple, this was a project that must have been begun many years, if not decades earlier. However, this estimate runs counter to the one given by Dumarçay, who recently declared that the construction of Candi Prambanan 'undoubtedly had begun in 832 and been completed in 856 , thus allowing only 24 years for the construction of the entire temple complex (Dumarçay 1993:74; see also Dumarçay 1991:55).

It is not, of course, the exact number of years by which the foundation of the temple should be pushed back in time that is at issue here, so much as the placing of the construction of the temple in another religio-political period, namely the so-called Śailendra interregnum. This latter implication has proved much less acceptable than I originally - perhaps somewhat naively - assumed, probably due to the fact that it is in contradiction with the accepted view of the Loro Jonggrang monument as a rival to Borobudur, intended to symbolically commemorate the regaining of the hegemony over Java by an indigenous Śaiva dynasty. Hence Dumarçay's estimate, which seems more inspired by De Casparis' conjectural interpretation of the inscriptional data than by architectural considerations: 832 is the year of the last Śailendra inscription and 856 the year of the Loro Jonggrang inscription. ${ }^{10}$ There were furthermore all kinds of stylistic considerations that seem to argue against an earlier dating. Subsequent research, however, has shown that neither the rivalry theory nor the arguments about style cut much ice, and that both had best be abandoned (Jordaan 1993). To prove the truth of this we will have to explore earlier conceptions of Loro Jonggrang, that is, the ideas held by archaeologists and art historians about who the builders of the temple complex were, and what the place of the temple was in the development of Hindu-Buddhist art in Java.

\section{About the founders, art styles, and archaeological theories}

If we step back to view the multitude, if not the web of views held by archaeologists about the dating and the religious background of Loro Jonggrang, we note a curious irregular development, which was at times in contradiction with the tangible results of excavations at the temple site and the analysis of in-

10 Contrast this to Van Lohuizen-de Leeuw's much more tentative estimate of Borobudur's construction period: 'the construction of this monument is likely to have started about AD 775 , but exactly how long it took to complete this enormous building is anyone's guess. though it probably took something like forty years' (1980:277). 
scriptions. A recent survey of earlier views on Loro Jonggrang (Jordaan 1993:523) showed the importance of a limited number of recurrent themes. These included: 1. the problem of the nearness of Buddhist temples; 2 , the demonstrable stylistic similarities with these and other Buddhist temples; 3, the presumed influence of the syncretic Śiva-Buddha cult; 4 . the position of the Śailendras; and 5 . the alleged rivalry between Loro Jonggrang and Borobudur.

If we once again recapitulate the discussion of the application of these themes, and supplement these with new details where necessary, it becomes evident that the first Dutch scholars examining Loro Jonggrang, following Mackenzie (1814) and Raffles (1817), identified the complex as Buddhist. In the process, the steadily increasing evidence of its Śaiva nature, in the form of statues and reliefs, was more or less consciously put aside (see Brumund 1868; Leemans 1873). To most of the early researchers, the proximity of various Buddhist temples was irreconcilable with the worship of gods belonging to a 'Brahmanic pantheon'.

Crawfurd $(1820 \mathrm{a}, 1820 \mathrm{~b})$ was the only early researcher who could not deny the evidence of Loro Jonggrang's Śaiva nature, although he could not gainsay the striking stylistic parallels with Buddhist structures like Borobudur either. $\mathrm{He}$ explained these correspondences by a presumed adaptation of Śaivism to Buddhism, which led him to speak of a 'reformed religion'.

Only with IJzerman's excavations (1887), which brought to light among other things the statue of Śiva Mahãdeva in the main chamber of the central temple, did the Śaiva nature of the complex seem to be definitely established. According to IJzerman, the physical proximity of Buddhist temples demonstrated the mutual tolerance between and peaceful coexistence of Buddhism and Śaivism in old Java. For some reason he spoke of 'a degenerate Buddhism and a vigorous Śaivism' (Uzerman 1887:271, 1891:55).

Groneman's subsequent research (1893) marked a temporary return to earlier positions, because Groneman, in spite of recent discoveries, maintained that Loro Jonggrang was in essence a Buddhist shrine. He recognized all sorts of objects, such as bells and trees depicted in the reliefs, as unequivocal specimens of Buddhist art. Particularly the poses and attributes of the various gods led him to suggest that they could only be expressions or manifestations of the Ädibuddha. To support his theory, he pointed to the Sutasoma as an example from Old Javanese literature in which the close relationship between Buddhism and Śaivism was discernible. In this way, the peaceful coexistence between the two religions was linked to the development in old Java of the so-called ŚivaBuddha cult, a syncretistic phenomenon that had already been pointed out by Crawfurd.

Later researchers, like M. Tonnet (1908) and G.P. Rouffaer (1918), referred to 
this relationship in similar terms. In order to be able to connect Loro Jonggrang with the advent of the Siva-Buddha cult, which was supposed to have flowered during the East Javanese period, in about 920-1500 AD, the construction of the complex was dated in the 10th century, at the end of the Central Javanese period.

This was supported by Brandes' influential article (1904), 'De waarde van Tjandi Prambanan tegenover de andere oudheden van Java, en een hartig woord over de deblayeering' ('The value of Candi Prambanan in comparison with other antiquities in Java, and a severe comment upon the clearing [of the temple site]'). According to Brandes, Candi Prambanan was a late creation of a Central Javanese art, tending towards decadence and decline. He believed he could discern signs of this decadence and degeneration in the exaggeratedly refined execution of the reliefs and statues. To Brandes, these art forms appeared to constitute the necessary link with the baroque art of East Java:

'Prambanan once again provides us with the intermediate form between old and young, between Central and East Java. The supple, weak, soft, though already monstrous shapes, in this ancient monument point to the excesses and the brutalization that so marks East Javanese forms.' (Brandes 1904:415.)

Both the presumed syncretistic nature of Loro Jonggrang and the connection with East Javanese art led scholars to look for a royal founder with East Javanese antecedents and syncretistic tendencies. To Rouffaer (1918), King Dakșa, to whom he attributed 'a syncretistic soul', appeared to be the appropriate candidate.

With Krom's now classic Inleiding tot de Hindoe-Javaansche kunst (Introduction to Hindu-Javanese Art) research moved in a new direction. Although Krom admitted that he found Rouffaer's arguments not altogether satisfactory (1923a, I:441), he suggested that it would be a good idea to use this royal name as a starting point when discussing the art of Loro Jonggrang, more because of King Dakșa's East Javanese background than because of his syncretism. Krom did not much care for what he called 'the daring theories' about Loro Jonggrang's Buddhist features (1923a, I:446), whereby he was referring to the results of iconographic research by Tonnet, who had shown that some of the alleged bodhisattvas in the bas-reliefs of the Siva temple were nothing other than Hindu lokapäla, or guardians of the quarters of the sky. It is significant, however, that Krom did not mention Tonnet's personal assessment of the temples 'as being of a Brahmanic conception, but of a Buddhist mood'. We will later see why.

First, however, we need to note that Krom, following Brandes, placed the construction of Loro Jonggrang at the end of the Central Javanese period. He, 
too, considered Loro Jonggrang to be the link with East Javanese art, although he expressed his ideas about this in a less biased and more subtle way than Brandes had. Noting that Dakșa ruled during the period in which Central and East Java presumably had been briefly united, Krom thought that there was discernible 'in his personality' something of the connection between the old, Central Javanese culture which would soon perish, and the new, East Javanese culture.

'With regard to art, a similar role is played precisely by Loro Jonggrang, which is equally a transitional monument. [...] While, to be sure, we are still dealing with a specifically Central Javanese art form here, insofar as the peculiarities noted in the development of that art find their continuation and final expression in Loro Jonggrang. There are apart from this all kinds of features that could be regarded as a preparation for and an explanation of what we will be able to observe at a later stage in East Java.'

Krom elucidates this by adding:

Loro Jonggrang [contains] forms that, although they cannot be simply styled East Javanese, indisputably bear within themselves the seeds of the development experienced in the East' (Krom 1923a:442).

Because of its size and beauty, Krom tended to view Candi Prambanan as a state temple. He attributed its construction to the Śaiva Javanese kings who came to power after the expulsion of the Buddhist Śailendras. Because of this religio-political background, Candi Prambanan was regarded as a Śaiva counterpart, if not a rival, of Borobudur. Krom saw in it 'the apotheosis of Śaivism, just as Borobudur had been that of Buddhism'. He continued,

'It is not impossible that in this grand creation of restored Javanese authority [...] there was something of a manifestation vis-à-vis the large sanctuaries of Mahāyāna Buddhism, which were so closely connected with Sumatran [Śailendra] expansion' (Krom 1923b:104-5).

Although Krom's rivalry theory would take archaeological research in a new direction, there were some dissenting voices to be heard in the short period between 1923 and 1931, the year in which the reprint of Krom's standard work, Hindoe-Javaansche geschiedenis (Hindu-Javanese History), appeared.

The first dissenting views were Stutterheim's, as set forth in his article on Old Javanese art (1923) as well as his well-known dissertation (1925). In both he expresses doubts about the unity of Hindu-Javanese art posited by Brandes and Krom, illustrating his arguments with a number of characteristic differences between Central and East Javanese art. Rather than calling it a transitional monument, Stutterheim considers Loro Jonggrang to be a purely Central Javanese temple, which in terms of design and execution belongs wholly to the Śailendra tradition. If Stutterheim is still somewhat ambivalent about the place of 
Loro Jonggrang within the development of old Javanese architecture in his first article, he is much more confident about the relationship between Loro Jonggrang and Borobudur and other Buddhist edifices in his dissertation.

As the title of his dissertation makes clear, he based his theories especially on legends about and reliefs showing Râma. Although they are separable, Stutterheim demonstrates those folktales and temple reliefs to be closely related. If the Malay and Javanese folk tradition includes Rāma tales that deviate more or less from the canonical Indian prototypes, such as the Bhattikävya and Vãlmiki's version, as evident in the wayang theatre, among others things, this is also true of the Rāma reliefs on the temples of Loro Jonggrang and Panataran. Contrary to the general practice in his days, Stutterheim did not consider it proper to speak of a 'misunderstanding' or 'corruption' of Indian materials in the indigenous adaptations. It seemed more probable to him that the differences noted ultimately derived from folk traditions which must have been current in India since ancient times, alongside the more authoritative versions. "I

The loose relationship between the Rāma reliefs of Prambanan and the Ramayana Kakawin, or Old Javanese Rāmāyana (OJR), which was also thought to have been composed in the 10th century, and the at times conspicuous similarities between these and tales from Sumatra as recorded in Malay hikayat, led Stutterheim to suspect a direct involvement of the Śailendras in the construction of the larger temples in Central Java. One should remember here that Stutterheim in his dissertation expressed the then dominant view that the Śailendras were originally Indians, who had settled in South Sumatra and founded Śrivijaya. From there they had extended their power and subjugated Central Java, which they ruled as a kind of protectorate.

More important is Stutterheim's observation that Śailendra influence on the monumental arts was not only noticeable in Borobudur and other Buddhist temples, but also in Loro Jonggrang. How this influence is to be explained is not wholly clear as Stutterheim has the construction of Loro Jonggrang start after the Śailendra kings have ceased to be heard about, 'because one cannot assume that these Buddhist zealots, given their position of power, would have allowed anything like that' (Stutterheim 1925:136; my emphasis). ${ }^{12}$

I1 Occasionally, one still comes across statements that seem to reflect a misinterpretation of Stutterheim's thesis, such as Dumarçay's (1978:58) claim that the representation of the Rãma story on the Prambanan temples is not meant to illustrate the Indian text but a Javanese adaptation'.

12 As said, this was a generally held assumption among scholars of Old Java, which made it very difficult for them to account for Loro Jonggrang's architectural and stylistic similarities with Buddhist temples. As was noted by Scheltema (1912:84) 'the] decoration, strictly Śivaitic on the inside while partaking of the Buddhistic on the outside, has racked 
With the expulsion of the Śailendras from Java and the re-establishment of their power in Sinvijaya, the connection between Java and India was temporarily broken, which affected the distinctive way in which the Javanese gave shape to the Hindu-Buddhist faith. One of the products of this independent development was Panataran, the Rāma reliefs of which, according to Stutterheim, are closer in content to the version contained in the Ramayana Kakawin (1924:190). This 'Javanization' of art, and of culture in general in the post-Śailendra period caused Stutterheim to deliberately write about Loro Jonggrang as a product of the period of the flowering of Hindu art in Java, in contrast with Panataran, which marked the high point of Hindu-Javanese art. ${ }^{13}$

It did not seem appropriate to Stutterheim to write about Loro Jonggrang and Panataran, given this difference in their art historical backgrounds, in terms of classical art as opposed to degeneration and decay, as Brandes and Krom had done. This error, according to him, caused something to be wrongly attributed to the Javanese, namely the art of Central Java, while denying the Javanese something that was rightfully theirs, namely the flowering of a new art form in East Java (Stutterheim 1925:209, see also 1926c:441, 1928a:688).

In other words, Stutterheim believed that there was no true unity in Old Javanese art. Thus he wrote that

'one should not set too much store by a "logical" development from Central Javanese to East Javanese reliefs. We should rather consider the possibility of a much greater difference being discernible between them than is usually assumed on Brandes' authority, in other words, that Javanese participation in the Hindu culture of Central Java started right after the Śailendras.' (Stutterheim 1925:216.)

He considered a possible carry-over of Śailendra influence out of the question. 'Śailendra decorative art (Borobudur, Loro Jonggrang) stood apart from the continuing development, and cannot have influenced it' (Stutterheim 1925:216).

The second dissenting opinion was voiced by J.L. Moens (1925), who addressed himself especially to the presumed anomaly of Loro Jonggrang's position amid the Buddhist temples. Unfortunately we are only familiar with Moens' opinion from secondary sources, namely the report of the first congress of the Java Instituut, at which Bosch gave an illustrated lecture on Prambanan.

many brains for an explanation: This can be illustrated with, for instance, a quote from Van Erp (1909:168) saying 'A special Buddhistic motive cannot in the nature of things be applied to a purely Śivaite structure, such as Candi Prambanan, but in the coincidence of the two copings in question [of the balustrade and its ornamentation] we think we may find a trace of Buddhist influence on the structural art of the Sivaites' (my emphasis).

13 Somewhat earlier, a similar view had been put forward by Van Erp, as is reported in the Proceedings of the First Congress of the Dutch Oriental Society (Verslag van het eerste. congres van het Oostersch Genootschap 1921:11-2). 
According to the report published in Djåwå (1925), which we will cite at length for the sake of historical completeness, Moens

'drew attention to the fact that in Mahāyāna Buddhism as practised in Java, the divine trio Śiva-Brahmā-Vișnu is incorporated into the Buddhist pantheon. He presumes, therefore, that Candi Prambanan is a Buddhist shrine, incorporated into the greater whole of Buddhist institutions. This supposition has much to be said for as it enables us to view all the antiquities on the Opak plain as part of a magnificent conception, the centre of which was formed by Candi Sewu, around which the other shrines were systematically grouped. The supposition of a Buddhist Candi Prambanan would also explain why many of the patterns and divine figares have such a limited Śaiva flavour.'

The report of the Java Instituut congress points out that in that case Candi Prambanan would have to date from the same period as the neighbouring shrines, namely the end of the 8th century, which would meet with serious objections. It cites Brandes' view on the stylistic peculiarities of Loro Jonggrang and their relationship with features of later, East Javanese temples. This view received general approbation:

The general opinion is that the Śaiva Candi Prambanan forms a contrast with its Buddhist surroundings. Indeed, its foundation has been regarded by some as a demonstration by a Saiva king against the Buddhist faith practised by the Sumatran overlords after these were expelled:

The report further makes clear that the speaker, Bosch, did not exclude a happy medium. He reminded the audience that

'King Dakșa, the probable founder of the temple, prefaced an inscription he issued with a double tribute, one to Siva and one to the Buddha. One might conclude from this that it was his wish to create a counterpart to the already existing Buddhist sanctuary Candi Sewu through the construction of a shrine dedicated to Siva, and thus juxtapose the shrines where the two highest deities, Śiva and Buddha, were worshipped. The results of the comparison of these two monuments are definitely compatible with the proposed solution. They balance each other completely. [and] all kinds of clues reinforce the impression that both foundations should be seen as equal halves of a whole - separated in time, united in faith.'

Concerning Loro Jonggrang's place in relation to the development of Javanese architecture, Bosch noted that even if Brandes' view had become the definite view on Prambanan, there were two negative factors affecting it, namely a western value judgement, as is evident from his use of words like 'brutalization', 'bastardization', and 'degeneration'. The other negative factor was the fact that Brandes and his contemporaries only had known Prambanan as an unexcavated ruin and thus seen it in a very incomplete form. On both counts, much had changed.

'In the past few years the view that we cannot speak of decadence in East Javanese art has gained more and more ground, and that an edifice like Candi Prambanan func- 
tioning as a link between Central and East Javanese art opened possibilities for a development of the art in new, Javanese ways.'

Concerning the comparison between Borobudur and Prambanan, Bosch points out the following contrast:

'In the former structure [there is] a scrupulous avoidance of everything that might stimulate the senses [and] endanger the viewer's inner peace. How different Prambanan [is], on the other hand! Everything the reliefs display is action and passion; the keenest movements are depicted with spirit and verve. Siva's cosmic dance of creation, with its intoxicating musical accompaniment and boundless excitement, is depicted in great detail here. If Borobudur's lion's heads appear to be gentle, on Prambanan they are grim, evil monsters lurking on the corners of the terraces. Thus we find the contrast between Buddhism and Hinduism faithfully reflected in the sculpture of these two monuments.' (Djåwå 1925:164-5.)

The degree to which Moens must have felt himself, or rather Javanese Buddhism, on which he had published a ground-breaking study one year earlier, misunderstood, and how he would have answered Bosch's arguments, can only be guessed at. He might, for instance have pointed out that King Dakșa's inscription with the double tribute to Siva and Buddha was found in a swamp near Gata or Getak, a village to the south of Prambanan. The inscription itself concerns a monastery (kawikuan) where Durgã was worshipped, and there is no way in which any wish of Dakșa's with regard to Loro Jonggrang or Candi Sewu can be deduced from it. Their separation in time is not a definite fact unless it can be proved that King Dakșa, ruler over parts of Central and East Java early in the tenth century, was involved in the construction of Loro Jonggrang.

Finally, Moens could have pointed out that the contrast between Prambanan and Borobudur as posited by Bosch was of a totally different nature from the religio-political contrast meant by Krom. In this connection he could have asked if Bosch, in using terms such as 'gentle' and 'grim' in his assessment of the differences between Borobudur and Prambanan, might have been guilty of the same western value judgements as Brandes, whom he had just tried to refute. However, Moens probably did not think that the first, festive congress of the Java Instituut, on Christmas eve, after a late-night wayang performance, was the proper occasion to engage in an academic dispute. That he remained silent, according to the report, is regrettable, as Bosch might have used his comments with profit when, not three years later, publishing the Kelurak inscription (Bosch 1928) provided evidence that Moens had been right.

Unlike the Dakșa inscription mentioned above, the Kelurak inscription originated from an area near the Prambanan temples, that is to say, near the Lumbung and Bubrah temples, which lie precisely in between the Sewu and Loro 
Jonggrang temples. Furthermore, its contents related to the temples themselves, as later became clear. The inscription commemorated the consecration of a statue of the bodhisvattva Mañjuśrī, which according to Bosch, probably consisted in placing certain religious formulas dedicated to the Buddhist Triratna gods, in a hollow space within Mañjuśri's statue. A couplet in which the Buddha, the Dharma, and the Sangha are named as being present in the innermost recesses of the statue, is followed by the sentence: 'He, the Vajrabearer, the Serene Highness, is Brahmā, Vișnu and Maheśvara. He, who is the Lord, encompassing all deities, is honoured as Mañjuvāc.'

All this led Bosch to suppose that the Kelurak inscription, as had been surmised by Moens, could have served as a kind of blueprint for the construction of an extensive Buddhist mandala, in which the unfolding of the Supreme Being in two directions was represented in a concrete form. Because of its importance, we will again quote Bosch's daring hypothesis in full. Bosch wrote:

Thus took place in reality what was so often described in the texts: the Supreme Being became manifest and passed into two visual manifestations, each in turn serving as a centre of lesser deities. Mañjuśri became manifest on the one hand in the Triratna, on the other in the Trimūrti: the former trio called into being a Buddhist mandala [comprising Lumbung and Sewu], the latter found honourable expression in Candi Prambanan [Loro Jonggrang].' (Bosch 1928:51.)

It is worth noting that Bosch did not extend his conclusions any further. Instead of taking the involvement of the Śailendras in the conception of Loro Jonggrang, as evidenced by the appearance of the name of king Śrī Sanggrãmadhanamjaya in the Kelurak inscription, as point of departure for further research into their real contribution to its construction, Bosch restricted himself to considering the question, as to whether the true order of the construction really mattered. Considering the unity of thought underlying the larger Prambanan complex, Bosch concluded that there were no dogmatic grounds for dividing the construction of the separate parts into successive stages. He added a paraphrase of Isaiah 28:16, saying, 'Those who believe are not in haste'. Where Moens had suggested that a Buddhist Candi Prambanan would at the same time explain why many motifs and divine figures were so lacking in Śaiva spirit, Bosch's sticking to a later date for its construction would continue the turbid discussion about Loro Jonggrang's supposed East Javanese stylistic features.

The only thing that Bosch did not neglect to emphasize was that the underlying Buddhist conception should not be understood in such a way as to give rise to the idea that Loro Jonggrang was itself a Buddhist shrine. Taking the distinction between Buddhist and Śaiva denominations in later Javanese inscriptions into account, Bosch believed it very likely that the Śaiva part of the 
population would have regarded the Trimūti sanctuary as its own and had it function in accordance with their Śaiva rites and ceremonies.

However interesting it may be to speculate about what other directions the research might have taken, we must note here that even Bosch's compromise received scant attention. Krom's negative judgement about 'daring theories' in regard to Loro Jonggrang's Buddhist character must have played a role here. Apparently Krom did not regard the congress report and the new evidence of the Kelurak inscription as providing any reason to change his mind during the preparations for the reprint of his book on Hindu-Javanese history. On the contrary, he stated his thesis about the rivalry between Borobudur and Loro Jonggrang with even greater emphasis than before (Krom 1931:172-3; see Jordaan 1993:10-1). It is true that Krom attempted to remove the impression that, with the disappearance of the Śailendras, Mahāyāna Buddhism, which had been so closely connected with this dynasty, would have receded into the background. The arguments he put forward in support of this, however, were rather lame and changed nothing in the theory of Loro Jonggrang's rivalry function, which would shortly be elevated to the status of archaeological dogma.

Significantly, in spite of the 10th-century date of the temple complex, Krom was unable to detect any clear evidence of art-historical or technical discontinuity at Loro Jonggrang. Contrary to Brandes' conclusions, his findings pointed only at a further phase in the regular process of development from the Buddhist art of the Śailendras to the later art of Central Java. The only respect in which Loro Jonggrang was different

'was the attempt to surpass all that had come before, to create by all means something that had never been seen before. However, precisely this [attempt at] reaching beyond the tradition adhered to so far, gives evidence also that some old principles of Hindu architecture were no longer properly understood. It is in this way that Loro Jonggrang foreshadows the art of East Java, where these principles were relinquished even further in favour of more Javanese-Indonesian conceptions.' (Krom 1931:173.)

Krom's careful but also rather vague statements about the 'preparation' and 'foreshadowing' of certain later artistic developments at Loro Jonggrang, which was nevertheless 'absolutely classically Central Javanese' (1923b:147) and 'faithful to Indian traditions' (1931:175), were so ambiguous that everyone was able to interpret them as they wished. This Stutterheim accordingly did, giving a new twist to the available data in order to fit them into the theory of the funerary function of Javanese temples, which he had just put forward and would gradually perfect (Stutterheim 1931, 1939, 1940).

Contrary to his earlier pronouncements about the essential difference hetween the art of Central Java and East Java, in which Loro Jonggrang was seen as a temple that was closely related to Śailendra monuments, Stutterheim's 
theories now betrayed an anxiety to remove the temple complex from its Central Javanese context. Curiously, he suddenly saw not just a few, but many East Javanese features in Loro Jonggrang. It would take us too far afield to discuss and explain this radical change in Stutterheim's views in detail. Suffice to say that it seems to me to involve his new ideas about the origin of the Sailendra dynasty, rather than just his funerary theory, the seeds of which can already be found in his 1923 article on Old Javanese art. Stutterheim had earlier quite convincingly defended an Indian connection, in which especially the importance of Nālandā in the North Indian state ruled by Harșavardhana (AD 606-647) and the successive Päla kings was pointed out. After taking cognizance of the newly discovered information provided by the Kedu inscription, however, he had the sudden idea that the Śailendras might have originated in Java itself (Stutterheim 1927:213). Without waiting for the reaction of his colleagues to this tempting idea, Stutterheim shortly afterwards declared this Javanese origin to be an established fact. In his well-known essay A Javanese Period in Sumatran History (1929b) he tried to demonstrate that it had not been Java that had been subjected to Śrivijaya, under the leadership of the Śailendras, but that rather the Śailendras originated in Java and had defeated Sumatra.

In spite of the strong and justified censure of this argument from, among others, Bosch (1929a), Stutterheim never abandoned his position, although he paid a high price for it in terms of credibility. Being a sharp and logical thinker, Stutterheim must have realized that with a Javanese origin for the Śailendras, the theory of the difference between Central and East Javanese art had lost its foundation and thus was only illusory. If the Javanese had played a leading role in the art of both areas, there had to be a conceptual unity. This helps to explain why he suddenly took offence at the term 'Hindu antiquities' and used that of 'Javanese antiquities' instead (Stutterheim 1931:1).

Something similar happened with his position on ancestor worship, which he originally allowed to surface again only after the expulsion of the Śailendras. Now, however, he claimed that the cult had never disappeared or been suppressed, and must have lain at the basis of temple construction in Central Java as well. Even the term 'temple' was attacked, in which connection he said, 'It is known to but a few that the so-called "Hindu temples" on the island of Java are not temples, nor were they built by Hindus' (Stutterheim 1931:1). Elsewhere he wrote:

'the temple was not a place of worship, but rather an ancestor house [...]. Temples in the true sense of the word do not exist in Java. What is called by that name in ninety out of a hundred cases is a funerary monument, where the king, now identified with a god, communicated with his descendants.' (Stutterheim 1930:10-1.)

Of course, Stutterheim knew full well that the influence of Hinduism on Java 
could not be denied, but he easily avoided this problem by positing that the influence was only superficial, saying:

'there are statues of gods, altars, reliefs with the holy stories of Viṣnu's avatärs, and other elements. Yet, closer examination has revealed that the statues are not mere representations of gods [...] they are images of deceased kings in the shape of gods.' (Stutterheim 1931:1.)

He even went so far as to deprecate the importance of treatises by leading scholars of Hinduism for an understanding of Javanese religious life during the so-called Hindu-Javanese period.

'No Colebrooke, Müller, Monier-Williams, Hopkins or Kern can be of any help to him [the student] here - he will have to put aside all the handbooks hitherto so diligently consulted and turn to the Javanese [ethnographic] data' (Stutterheim 1940: 232, compare 1930:10).

He now dated the appearance of Hindu teachers to before AD 700; being diligent pupils, the Javanese apparently were able to soon do without these. Stutterheim marginalized the influence of Hinduism even further by considering it as one of the many foreign influences that had left their stamp on Javanese spiritual life, referring more and more in his writings to China, Mesopotamia, Greece, and Egypt. Where others tended to avoid such broad perspectives, Stutterheim (1929a:52) wrote that 'with every new investigation these dim origins assume clearer forms. Far beyond these origins the scouting vision discerns more distant, hazier beginnings - but that is another story.' Let us return to our discussion about Loro Jonggrang.

It is quite understandable that Stutterheim should have considered Candi Prambanan crucial for his funerary theory, especially in view of the bones and ashes that IJzerman (1891) had found in some of the temple pits. If in the past he had occasionally cast doubts on whether Loro Jonggrang was a mausoleum (Stutterheim 1925:137, 1928b:130, note 20), he now did not shrink from labelling the temple as a royal ancestral abode or sepulchral monument. Unlike Rouffaer and Krom, Stutterheim was not thinking of King Daksa here, but rather of the latter's predecessor, King Balitung, who reigned from AD 898 to 910 . This was possibly because of Daksa's syncretism, which was difficult to square with Loro Jonggrang's function as a rival to Borobudur, and had in any case now become superfluous as an argument. Stutterheim interpreted Loro Jonggrang wholly as a royal mausoleum, declaring the statue of Śiva Mahãdeva to represent King Balitung, and the statues of Durgã and Ganesa to represent the latter's main consort and army commander, respectively, and so on. It all sounded so convincing that even Moens was won over and later 'declared this fairy tale to be real' (Moens 1953). 
According to Stutterheim, the dating and the possible involvement of this East Javanese ruler, as well as perhaps his successor, were confirmed by arthistorical studies by Brandes, whom Stutterheim, it may be noted, had suddenly named 'the father of Dutch East Indies archaeology'. Contrary to his earlier statements, he now said that Brandes had

'shown that the ruins of the Prambanan temples differ from other Central Javanese antiquities among other things on the point of the peculiarities of their architectural style as well as that of their arrangement. These are not familiar to us from Central Java, but rather from East Java.' (Stutterheim 1940:219.)

One would almost begin to doubt that Loro Jonggrang had been built in Central Java.

In addition, Stutterheim drew attention to Van Erp's 'marl theory', which classed Loro Jonggrang among the most recent temples in Central Java on account of the use of marl to fill the space between the stone walls of the temple rather than with stone, which was much more difficult to work. He assumed that this replacement of a difficult technique with a simpler and less time-consuming one was irreversible and in keeping with the on-going simplification of architectural techniques that was observable in Hindu-Javanese art. Stutterheim's application of the marl theory is extremely surprising, considering that some years earlier he had rejected it as a reliable dating method with the utmost certainty. 'Marlstone as a filling material', he concluded then, 'can tell us nothing about the time [a temple] was built' (1935:89).

In order to understand the progress of the scholarly discussion, it is important to note that not only are Stutterheim's interpretations tendentious, but they had also surreptitiously added a new dimension to the concept of 'East Javanese stylistic features'. Krom's 'foreshadowing' or 'anticipation of the art of East Java' in Stutterheim's treatment had imperceptibly changed into a positive assertion of the actual presence of East Javanese stylistic elements. The presence of these elements in Prambanan has never, to my knowledge, been subject to a special art historical inquiry, an omission that would not be without certain consequences, as we will see.

After the interruption caused by the Second World War and the subsequent Indonesian struggle for independence, the research into the early history of Central Java started up again in the 1950s. Two developments are of special importance here. The first of these was the undermining of the funerary theory by the publications of Bosch (1954), O'Connor (1964) and Soekmono (1974). My own explorations, which were restricted to Loro Jonggrang, also confirmed that Stutterheim's arguments were both incomplete and invalid (Jordaan 1989: 
21). ${ }^{14}$ The second development was the progress made in epigraphic research by De Casparis $(1950,1956,1958)$, in which connection the metric Old Javanese inscription of $856 \mathrm{AD}$ is especially relevant in regard to Loro Jonggrang. As was pointed out earlier, De Casparis discovered that a part of this inscription was a detailed description of a Śaiva temple complex which reminded him strongly of Loro Jonggrang. In reply to the question as to whether the two could be identified with each other, De Casparis wrote:

In spite of the curious correspondences, there is no sufficient reason to give a positive answer to this question, although it cannot be denied that the shape of the complex founded in $856 \mathrm{AD}$ agrees with the Lara Djongrang temples in more than one respect and Çaiva complexes of such an enormous size have been rare. The main objection, however, is the date of Tjandi Lara Djongrang, considered to belong to the first decennia of the 10th century $A D$, i.e. at least half a century later than this inscription is.' (De Casparis 1956:309.)

De Casparis, however, noted that the arguments about the date of the temple complex put forward by Krom and Stutterheim, did not perhaps constitute as strong an objection as might have been thought at first. He himself had shown, for instance, that the Buddhist temple Candi Plaosan, which according to Krom was contemporary with Loro Jonggrang, had to have been built much earlier than the beginning of the 10th century, in view of the fact that the name Rakai Pikatan occurs in many short inscriptions found near the temple. Rakai Pikatan is the same ruler to whom the Loro Jonggrang inscription of $856 \mathrm{AD}$ mentioned above probably referred.

De Casparis further observed that, contrary to what Stutterheim had claimed, the short inscriptions of Plaosan and Loro Jonggrang were written in a script that was noticeably more archaic than that used in the time of Balitung and Dakșa. He nevertheless felt that 'the whole problem' had to remain undecided and that more evidence was needed to disprove the long accepted date. ${ }^{15}$

This overly cautious conclusion was not shared by De Casparis' archaeological colleagues. Bosch (1958) was the first to declare himself to be convinced that De Casparis' intuitions had been right and that the temple described in the inscription was in fact Loro Jonggrang. In further support of this identification he pointed out that Van Erp's 'marl theory', which Krom had used in his

14 Occasionally the idea of Prambanan having a funerary function was still expressed, for instance by J. Ensink (1978), who called it a mausoleum for King Balitung, and Helfritz (1979:112-9), who interpreted it not only as a sepulchral monument for a deified ruler, but also as a burial shrine for Mahãyãna Buddhist monks.

15. Elsewhere (Jordaan 1993:19-20) 1 have shown that De Casparis did in fact use Vogler's (1953) newly modified art-historical interpretations to support his own dynastical theory. which in turn would strengthen the theory concerning the alleged Borobudur-Prambanan rivalry (see, for instance, Dumarçay 1986b:42, 1993:74-8; Miksic 1994). 
tentative dating, had in the meantime become untenable. Regarding importance of stylistic considerations, which 'had always weighed most heavily in attributing a late construction date to Loro Jonggrang', Bosch stated that he was

'no longer inclined to attach as much weight to them, in view of the fact that these [considerations] give the strong impression that they have been influenced by Brandes' famous essay "De waarde van Tjandi Prambanan tegenover de andere oudheden van Java, en een hartig woord over de deblayeering" for a half century, without any critical examination. More convincing arguments than those of Brandes have since not been advanced.' (Bosch 1958:318, note 10.) 16

It would not be long before other archaeologists and art historians would accept the identification of Loro Jonggrang with the epigraphical description as being quite acceptable, if not an established fact (for example Bernet Kempers 1959; Soekmono 1965:42; Boechari 1965:63; Holt 1967:54; Satyawati Suleiman 1976:12; Williams 1981; Dumarçay 1986a, 1993). Most of them supported De Casparis' idea, derived from Krom, that the construction of Loro Jonggrang must be seen against the background of a power struggle between the Śailendras and the renascent Sañjaya dynasty, under the leadership of Rakai Pikatan. About this De Casparis had written: 'The consolidation of the dynasty of Rakai Pikatan marked the beginning of a new period, which had to be inaugurated by the foundation of a great temple complex' (1956:300).

In the face of such unanimity, there were only two scholars, L.-Ch. Damais (1968) and W. Aichele (1969), who accepted the proposed identification without subordinating their own ideas to De Casparis' dynastic theory in the process. Both were brilliant philologists and had, independently, taken the trouble to critically re-examine the translation of the Loro Jonggrang inscription, arriving at an interpretation that deviated from that of De Casparis on some important points. They doubted, for instance, if the expression jatiningrat, used in the inscription, could be interpreted as a title assumed by the ruler, Rakai Pikatan, on becoming a royal hermit, shortly after his defeat of the Śailendras. To Aichele, it seemed more likely that jatiningrat was an allusion to or a euphemism for his death, rather than a royal title. He concluded from this that the inauguration of the Śiva temple, which was named in the Loro Jonggrang inscription, had perhaps been intended to commemorate the anniversary of king Pikatan's death.

16 In spite of this caution, one can still pick up faint echoes of Brandes' opinion, such as in De Grote Winkler Prins Encyclopedie (1982, vol. 18:653) and Fontein (1990:79) who mention Loro Jonggrang's alleged caricatural tendencies and its symptoms of stagnation and rigidity. The new dating of the temple complex would seem to invalidate these statements even further by bringing them to bear on contemporary Buddhist structures such as Sewu, Plaosan, and Sojiwan, which have never evoked such appraisals. 
Damais objected both to the hypothesis about the coexistence of two rival dynasties and to that of their alleged spheres of influence, as the theory of an overlap of the political and the religious spheres to him was too reminiscent of European thinking during the Middle Ages or the Renaissance. ${ }^{17}$ Although it was evident, according to him, that the rulers had their own religious preferences, it still seemed true that the two denominations, Buddhism and Śaivism, had long coexisted in Java (Damais 1968:375).

For all kinds of reasons that need not be discussed here, Aichele's conclusion failed to receive attention. At a given point I wanted to check De Casparis' theory concerning the location of the sacred pool (tirtha) in the temple grounds against my own (Jordaan 1991a). As a background to this, I included a short summary of Central Javanese history that was more or less in line with De Casparis' dynastic theory, but later realized that the reconstruction here was faulty and that satisfactory results could only be achieved if De Casparis' conflict model was abandoned. The direct cause of this was my having made acquaintance with the contents of the Wanua Tengah III inscription discovered some years previously (Djoko Dwiyanto 1986; see Jordaan 1993:49-51). This inscription contains a list of names of twelve kings who ruled before King Balitung. One of them was Rakai Pikatan, of whom it was said that he had died in AD 855, hence the same year that had been proposed by Aichele on the basis of his reading of the Loro Jonggrang inscription. This provided irrefutable proof that Loro Jonggrang had not, as was still generally assumed, been built by Rakai Pikatan in 855 or later, but much earlier.

How much earlier depends on the right reading of the Loro Jonggrang inscription, on the basis of which the progress of the construction can be determined. Even if we accept Aichele's view and assume that the Loro Jonggrang inscription of $856 \mathrm{AD}$ referred to the inauguration only of the main temple dedicated to Śiva, it would still be impossible to accept this temple as having been built in the period between 855 and 856 . This implies that Rakai Pikatan, or perhaps even his predecessor, must have started the construction, possibly some decades earlier. If this line of reasoning is correct, it follows that Loro Jonggrang could not possibly have been intended as a rival to Borobudur, since the Śailendras still reigned supreme in South Central Java at that time.

In my opinion, this argument should be carried even further, to call into

17 While Damais perhaps may have been reminded here of the geopolitical doctrine of cuius regio eius religio promulgated in Augsburg in AD 1555, I think that the suggestion by Dutch archaeologists about a social differentiation along religious-ideological lines may well have been inspired by examples from Dutch history, notably the Verzuiling during the latter half of the 19th and first half of the 20th century. The Dutch-European model, however, does not quite fit with Javanese or other Southeast Asian realities. 
question the thesis of dynastic rivalry itself. ${ }^{18}$ Was Rakai Pikatan not married to a Buddhist princess and did he not help with the construction of the Buddhist Plaosan temple complex? Hence, would it not equally be possible that the Śailendras helped with the construction of a Śaiva temple complex, especially since it had been proposed to build this in an area dominated by Buddhist temples? ${ }^{19}$ Further, how are Moens' and Bosch's ideas about Loro Jonggrang's Buddhist background, which have so long been neglected, to be judged? The wish to draw attention to these ideas prompted the writing of my study Imagine Buddha in Prambanan (Jordaan 1993).

As the title indicates, the aim of this booklet was to reconsider the idea of a Buddhist background of the Loro Jongrang temple complex. Support for this idea was found in P.H. Pott's dissertation (1946, 1966). Pott, following Moens, noted that the purport of the Kelurak inscription was quite in harmony with the ideas of Tantric Buddhism. He only referred in very general terms to the Prambanan temple complex, identifying Sewu-Bubrah-Lumbung as the 'superstructure' and Loro Jonggrang as the 'foundation' of the Tantric Buddhist system. Pott wrote:

'Here, apparently, an intentional demarcation is made between two parts of the system: a Buddhist upper part, based on a Śaiva foundation, in which the former represents the "left-hand path" and the latter the "right-hand path" of Mahāyoga. It may be remarked therefore that the terms Buddhism and Śaivism are here in fact designations of the two parts of which Tāntrik Yoga is composed, and there are indeed facts from East Java and Bali which indicate that this distinction is intended by the use of these terms.' (Pott 1966:120.)

In this connection, Loro Jonggrang's Buddhist background was reported to have been noted again by B. Rowland (1953), who recognized it as an 'ultimate derivative' of Pāhārpur, also known as Somapura, a Buddhist sanctuary in Bengal. The connection he establishes with Bengal is supported by the Kelurak inscription, which reports that the consecration of the Mañjuśri statue was performed by a guru who came from Gaudidvipa, which probably stands for Gaựivișaya, a district in East Bengal (Bosch 1928:29-30). At the time of the

18 Rakai Pikatan's involvement in the construction of Loro Jonggrang was surmised by Le Bonheur (1971:87) and Miksic (1990:24), though both authors stopped short of considering the possibility that the construction was also supported by the Śailendras, to whom Rakai Pikatan (and his predecessor?) may have been related through a marital alliance.

19. According to the Loro Jonggrang inscription, '[the king] was a Śaiva, contrary to the queen, the spouse of the hero'. Accepting that Rakai Pikatan was married to a Buddhist princess, I cannot agree with De Casparis, who identifies this princess with the figure of Śr̃ Kahulunan. Following Boechari (1982:15-22), I am inclined to believe that the title Śri Kahulunan refers to the king's Buddhist mother, with whom Rakai Pikatan built Candi Plaosan. The full implications of this idea will be investigated in a separate study. 
Kelurak inscription, both Gauḍivișaya and Pāhārpur formed part of the allpowerful Buddhist Pāla state, which at that time was ruled by Dharmapāla (c. 770-810). Other art-historical studies confirm this view on the influence of the Pāhārpur model in Southeast Asia to some degree (Van Lohuizen-de Leeuw 1956:279; Huntington 1985:390-1; Khanna 1992:212). S.K. Bhattacharya (1978:73) goes furthest in this, positing that, according to the canons of Indian temple architecture, the temple of Pāhārpur is of the 'Sarvato-Bhadra' type. This type of temple is quite unique, he observed, as the only existing examples of it are to be found in Burma and in Java, namely the temple of Candi Loro Jonggrang, and Candi Sewu. ${ }^{20}$

Assuming the theory of this art-historical link with Pāhārpur to be correct, we can formulate a number of new hypotheses. The first of these concerns the close relationship between the two religions, in the way that Moens had thought possible at Prambanan. It has become evident from excavations at Pāhārpur that such a fusion between Hinduism and Buddhism had also taken place there. A.N. Khanna reports that 'divine figures, both Brahmanical and Buddhist', were found among the statues excavated at Pāhārpur, although it is not clear how some of these statues came to be placed there. According to J.E. van Lohuizende Leeuw (1957) and S.K. Saraswati (1962), the statues and reliefs do not all date from the same period and it seems likely that especially the Hindu reliefs, among which episodes from the Rāmāyana and from the life of Kṛșna have been recognized, came from elsewhere, possibly from some ruined Hindu temple. Van Lohuizen-de Leeuw notes, however, that at a later stage, as a result of doctrinal changes in Buddhism, people did not scruple to reuse remnants of Hindu shrines on Buddhist temples and even to reserve space on the temple itself to replace the relief panels. 'For by this time Buddhism recognized the existence of the Hindu gods, though they were inferior to the exalted Buddhist beings' (Van Lohuizen-de Leeuw 1957:42).

The ultimate fusion of the two pantheons seems to have been the result of the development of Tantric Buddhism during the Pāla period (Mallar Ghosh 1980:1). Unfortunately, we cannot determine, at the present stage of our knowledge, how far this fusion actually went, how it was experienced by those involved, and by whom and where these teachings were stimulated most, in India or in Southeast Asia. While N. Dutt (1978:15) suggested that the fusion was perhaps more advanced in Java and elsewhere in Asia than in India, H.B.

20 Van Lohuizen-de Leeuw (1957:33) writes 'This cross-shaped ground-plan and terraced superstructure became popular somewhat later in several parts of Southeast Asia and confirms the view that the Buddhist centers in Bengal exercised a considerable influence on such countries as Rurma and Java'. 
Sarkar (1967) and others lay the emphasis on India's input in this, ${ }^{21}$ Sarkar points especially at the influence of Bengal, saying: "The Tāntrik contents of East Indian Buddhism, fostered in the Nālandā school of thought and in PălaBengal, reinforced by Buddhist missionaries [...], powerfully affected Indonesia' (Sarkar 1967:639).

As far as the date of this development is concerned, Sarkar was inclined to think, 'on theoretical and general considerations', that the religious synthesis was worked out in Java during the period between the 8th and the 9th century (Sarkar 1967:640). Elsewhere (Jordaan 1993) I have expressed doubts about this, primarily on the grounds that most of the references given by Sarkar relate to Old Javanese literary works that were written much later, in the East Javanese period. The Kelurak inscription (AD 778) is the only text dating from the Central Javanese period, and seemed ambiguous to me, considering Mañjuśrí's preeminent, encompassing, divine nature. In addition there is the Nālandā inscription, which was issued in about AD 860 on the orders of Bālaputra, the Śailendra ruler of Śrivijaya. Although figures from the Buddhist and Hindu pantheons are still juxtaposed here (which is quite significant, after Bālaputra's recent expulsion from Java and the revival of Śaivism there), a more prominent position for Buddhism can be deduced from it, too.

In the absence of contemporary epigraphical evidence, Loro Jonggrang, paradoxically, provides the only concrete indication that the Śailendras bestowed their royal favours not only on Mahāyãna Buddhism, but also on Śaivism. I make this assertion on the basis of the above line of reasoning that the construction of the Siva temple, and perhaps of several other parts of the complex as well, had been begun during the Śailendra period, and that it was probably conceived and executed with their cooperation. If Loro Jonggrang and Candi Sewu had indeed been conceived as parts of a large-scale place of worship, the whole area would have been regarded as sacred and dedicated to Parambrahma(n) (the 'Universal Soul', 'World Spirit,' or 'Absolute'), which name would ultimately have been corrupted into Prambanan. ${ }^{22}$ In view of their

21 We can safely assume that the exportation of Tantra beyond the Indian border could not have been without a flourishing activity in India' (Gomez 1987:375). Verwey (1962: 141), however, thinks in terms of a lively two-way sea-traffic of missionaries and pilgrims, giving and taking, understanding each other and largely speaking a single symbolic language.

22 I cannot possibly consider the question as to how the Javanese Buddhists would have handled the religio-philosophical problems connected with this application of the Brahman concept. For the sake of further comparative research on this complicated question, 1 refer the reader to Bhattacharya's 1973 study. Additional information on the application of the concept in Old Javanese texts from Bali and East Java, where Parambrahma denotes both a Personal God and an Abstract Principle, can be found in Haryati Soebadio (1971). 
specification as separate 'Houses' (Śivagṛha and Mañjuśrīgṛha respectively) in the inscriptions, $I$ assume that Loro Jonggrang was meant to be, and functioned as, an independent Śaiva temple complex. Such a 'coalition' of the two main religions would have been similar to the situation found in East Java later, about which Haryati Soebadio noted that 'many facts plead more for a long standing peaceful coexistence of Buddhism and Śivaism as two independent and equally respected systems rather than for an interrupted adherence to either of these religions by any state' (Soebadio 1971:61). Still, the distinction between Hinduism and Buddhism may have been only of relative importance in the heyday of Central Javanese history, when the fusion went further than we are able to imagine at present - in keeping with Paul Auster's remark that the real is always ahead of what we can imagine. If Tantrism had indeed been known in Java at an earlier time than is now still generally assumed, denominational differences would have been vague and unimportant (see Kern 1888). This would corroborate Stutterheim's thesis that

'the name "Buddhism" is quite misleading for Java. It would be better to speak of Tantrism on a Buddhist base. But Tantrism is as much Śaiva as Buddhist and the differentiation is based more on flavour than on reality. In reality they are both equal and were so in India as well.' (Stutterheim 1925:288.)

Although I personally am sympathetic towards the view that the fusion of Śaivism and Buddhism occurred in Central Java, I must reluctantly assume with Bosch (1928), because of the scarcity of epigraphical evidence, that the Śaiva part of the Javanese population considered the Trimūrti sanctuary as theirs and that they used it in accordance with their Śaiva rites and ceremonies. To test the validity of this assumption, we will have to find out if and how Loro Jonggrang was incorporated into the larger whole in which the nearby Buddhist temples also have their place. ${ }^{23}$ The relevance of this question also becomes clear in the advisory committee's report on the restoration of Loro Jonggrang:

'Finally, the location of the temple complex in relation to other antiquities on the Prambanan plain (the kraton of Ratu Boko, Candi Sewu, etc.) needs to be investigated and determined by a boussole [compass] etc. It is probable that here, too, there was question of a quite intentional design, the discovery of which may be of importance

23 This hypothesis is important to my argument, because of Ensink's (1978:181) assertion that during the Central Javanese period 'apparently Śivaism and Buddhism were supported by the rulers alternately or even simultaneously. Although the two religions seem to have been tolerant towards each other, there is not the slightest hint at a relation of a theological nature between the two: Sivaite monuments are Sivaite without reference to Buddhism and vica versa; and likewise the inscriptions'. Apparently Ensink overlooked the hint of the Kelurak inscription which may have provided the theological basis for the construction of both Candi Sewu and Candi Loro Jonggrang. 
with regard to religio-philosophical, historical, archaeological and architectural values, as well as the temples themselves.' (Verslag 1926:37.) ${ }^{24}$

Whatever the results of this still unaccomplished research may be, the new dating of Loro Jonggrang would seem to release us from the idea that the monument was intended as a religio-political rival to Borobudur.

In conclusion, it may be useful to note that the reinterpretation of the meaning of Prambanan in the development of Central Javanese art dovetails nicely with other recent ideas about the relationship between Hinduism and Buddhism in ancient Central Java (Fontein 1990:38). A report by the Indonesian archaeologist Soekarto, as cited in Kompas of 17 July 1993, on the presence of ruins of Hindu shrines and the discovery of an inscription in the form of a linga near Borobudur, is interesting in this connection, strengthening the suspicion that this sanctuary used to be surrounded by Hindu shrines, just as the reverse was true at Prambanan. Also worth noting in this connection are the recent discoveries of statues from both pantheons at different temple sites: a small bronze statue of the bodhisattva Vajrapāni in the Saiva temple Candi Sambisari, and a silver one of Śiva in Candi Sewu (see section 8).

These facts are of course more easily explained by reference to a peaceful coexistence of the religions than through the changing fortunes of a struggle for hegemony, as De Casparis and his followers tried to do. One could furthermore ask whether this struggle for hegemony should not be interpreted in terms of a competition for royal favours and easy access to the kraton, which would probably in the main have been irrelevant to the common people.

\section{The mythical Mount Meru and the churning of the ocean}

Having considered Loro Jonggrang as a royal mausoleum and as a rival to Borobudur, we will now consider the meaning, or rather, the multiple meanings, embedded in the design of the temple complex. Possibly in this way more justice will be done to the intentions of the builders.

One of these meanings is the representation of the temple as a replica of Mount Meru, the Abode of the Gods. We do not at this point need to go into the general validity of this interpretation, which has been discussed and documented by numerous scholars (for instance Van Eerde 1911:15-29; Stutterheim

24 Several other scholars, both carlier and later, noticed the striking similarities in the design of Loro Jonggrang, Sewu, and the Plaoson temples. Their remarks were not followed up with much concrete research, however. See, for instance, IJzerman (1887:266, 1891:41). Groneman (1887:1435), Le Bonheur (1971:54), and Edi Sedyawati (1978a). 
1926b; Heine-Geldern 1930; Mabbett 1982; Snodgrass 1985:261-2). According to Stutterheim

'we find the idea of the Meru, the replica of the cosmos, most clearly expressed in the candi of Loro Jonggrang at Prambanan. Here we find successively the motifs of the tree of heaven and of the lion in the sub-basement, the celestial singers, dancers, and musicians along the stair railings, the protectors of the cardinal points at the foot of the body of the temple, and, finally, the images of the deities so placed in the niches and the interior of the temple that the composition as a whole unmistakably indicates it to be a mountain of the gods. In addition, the antefixes, omaments in the shape of tridents, emphasize by the typically mountainous symbols the rocky character of the whole structure.' (Stutterheim 1929a:41.)

That this image is indeed what Prambanan's architects intended to project is clear from the Old Javanese Rāmāyaña, parts of which, we have good reason to believe, date from the 10 th or even the 9 th century $\mathrm{AD}$ - that is, from a period immediately after that of the construction of the temple (Poerbatjaraka 1927, 1932; Aichele 1969:162-3). One such part is the description of Loro Jonggrang, which compares that shrine explicitly to the mountain of the gods, here called Mandara, one of Mount Meru's many names. It runs: 'The crystal palace was comparable to Mount Mandara, the [temple] square to the Ocean of Milk' (Poerbatjaraka 1932:162).

This textual corroboration is archaeologically very important. Stutterheim believed that this conception of Meru was not just an idea, but rather was a principle constituting the very basis of temple architecture in Java, and that 'the systematic analysis and elaboration of this phenomenon would definitely and immediately eliminate hundreds of minor, as yet unresolved difficulties [...], and not only with respect to Java' (Stutterheim 1926b:342).

An apt example of the heuristic value of this idea is provided by Tonnet's (1908) identification of the bas-relief images of gods on the exterior wall of the Śiva temple. Referring to Coleman's (1832) study on Hindu mythology, containing a diagram of a cross-section of Mount Meru showing the 16 celestial mansions of Indra and other gods in the upper part, Tonnet was able to identify the majority of the images of gods on the Śiva temple as Hindu lokapāla, or guardians of the sky. She suspected that of the total of 24 deities, eight were identifiable as guardians of the sky. Each of these was depicted twice. Hence the number of panels they occupied was therefore precisely the number listed by Coleman.

In spite of the early scholarly consensus about the importance of the Meru symbolism, however, the Hindu Javanese temple was soon to become known for its singular function as a royal mausoleum. The Meru idea consequently somehow disappeared in the process. This did not help the research into the religious 
significance of Hindu temples in general, and of Loro Jonggrang in particular.

Ironically, this was due largely to the efforts of the same Stutterheim who had earlier indicated the potential benefits of Meru-focused investigations. If the Meru image was mentioned at all, this was done mostly superficially and perfunctorily (see Stutterheim 1940:230; Bernet Kempers 1955:21; Soekmono 1993:53). Only an occasional author makes some interesting comments, albeit, unfortunately, without supporting these with pertinent references to the literature. I am thinking here, for example, of Lokesh Chandra and his idea that

'the 224 peripheral temples [candi perwara] represent the 224 universes of the cosmological system of the Śaiva Siddhãnta according to Bhuvanakosha. [...] While these peripheral temples may correspond to the Chakravada mountains, the eight temples in the inner court may be the eight pinnacles of the Mânasa mountains. [A] precise interpretation awaits research.' (Lokesh Chandra 1967:251.)

My own interest in the Meru symbolism was aroused on my becoming acquainted with the problems of interpretation of the ritual deposits in Javanese temples, especially those of Loro Jonggrang, which had played such a crucial role in the development of the funerary theory. Although, as a result of research by Bosch (1954) and Soekmono (1974), this theory has lost much of its foundation, no satisfactory explanation has, to my mind, been found up to now for the ritual deposits, 25

If, therefore, it was erroneous to label the small stone boxes found in these temple as 'coffins' or 'urns', then how should the ashes, the small gems, the animal figures cut out from gold leaf and the letter-like objects these boxes contained be interpreted? And what to think of the three animal skeletons and one human one that were found elsewhere in the central temple compound? It did not seem logical to me to just lump all these things together without further questioning (see IJzerman, this volume).

Following Stutterheim I therefore limited myself to the deposits in the Śiva temple, which he had considered the 'heart' of the complex. Contrary to Stutterheim, however. I considered it incorrect to view the small animal figures and letter-like objects as magical, Tantric symbols without reference to the liturgical literature. Stutterheim qualifies these as: 'the symbols of those divine principles which correspond with the different elements of the human body; by these it

25. It should be noted that my judgement was partially influenced by the circumstances under which 1 did my research. My first publication was written during a stay in Jakarta (1988-1992), when I lacked proper access to the recent literature. For this reason I was not aware of, and had no opportunity to become acquainted with some relevant publications such as Aichele (1969), Van Liere (1980), and Treloar (1972). Treloar's analysis of the chemical treatment of the ritual deposits from Hindu temples in Malaysia should be mentioned especially here. 
would be possible at all times to give the deified ruler a temporary body, in case his descendants wanted to honour or consult him' (Stutterheim 1940:226).

1 called this vague reference to Tantric doctrines a convenient stopgap that concealed more than it clarified. As long as we knew next to nothing about the ancestor worship, as was posited by Bosch (1954), it did not seem rational to me to consider the ritual deposits as 'valuables' (saptaratna) to be sent along with an imaginary deceased ruler on his joumey to the hereafter, whether as payment or as food for the gods (Scheltema 1912:77-8; Van Blom 1935:110).

Soekmono's suggestion, derived from O'Connor (1964), that the ritual deposits might be connected with certain cosmological classifications, such as those of the aștadikpála, did not seem viable without reference to definite directives from Hindu building manuals that were followed in the construction of Prambanan. Because the snake, the elephant, the turtle, and the gems could be considered as earth symbols, I wondered if the ritual deposits, including the ashes, in the pit of the Śiva temple might perhaps be interpretable as a collective symbolic reference to the well-known Hindu myth of the Churning of the Milk Ocean. ${ }^{26}$ This led me to re-examine the textual references to the temple in the Old Javanese Rāmāyana and to compare the latter with the text of the Loro Jonggrang inscription where possible. In the process a number of truly spectacular facts came to light. The description of the temple in the Old Javanese Rāmãyana confirmed not only the supposition that the temple was being compared to Mount Mandara, but also the importance of the myth of the Churning of the Milk Ocean. Because of its relevance to the rest of my argument I will reproduce the greater part of this description below. The English translation is based on Poerbatjaraka's Dutch edition of this part of the OJR text (see also Soewito Santoso 1980:210-4). The temple is described from Hanumān's viewpoint.

'Hanumân looked in the direction of the city, which was clearly visible. There was a temple, tall and large, which looked as if it was made of crystals and precious stones.

There were animals depicted in its carvings: golden hares, elephants, lions, tigers, gazelles, wild boars, and rhinoceroses. The picture of a forest was carved out in it as well. The temple resembled a mountain. (44)

The temple square was fashioned out of gems and candrakānta stones. The sand consisted of splendid fine pearls. When the moon rose they turned liquid and cold, melting in the square and shining brightly. (45)

The crystal temple was comparable to Mount Mandara, the square to the Milk

26 This idea first occurred to me on reading Voorhoeve's (1958) description of a Batak cosmogonic ritual, in which very similar symbols were used. Recently, I discovered that Lamb (1960:87) had earlier proposed that the arrangement of some of the ritual deposits in the Kedah temple excavated by him could well suggest Vișnu churning the Milky Ocean. 
Ocean. Gems and pearls represented the foam, so to speak; the clear cold water was like nectar (rising from the Chumed Ocean), (46)

There were radiant, decorated tambak, ten in a row, comparable to the surf, the great waves. The kettledrums beaten in the temple were comparable to the roaring of the (Milk Ocean) sea. (47)

Outside, there were ãvarana, small and exquisitely fine temples, all carved out of black precious stones. They were comparable to the reefs enclosing the Milk Ocean. (48)

These outer temples all contained gold statues comparable to the gods and demons attacking each other in order to obtain the amrta, which was their goal, (49)

The statues were all armed, bearing clubs, javelins, bows, spears, swords, disc, and vajra too. They looked as if they were fighting for the amrta. (50)

There were also suwuk over the doorways of the temple containing the statues. These suwuk were beautifully carved out of gems and candrakānta stones. There eyes were round, staring and protruding. He (the suwuk) was like Răhu, as it were, who also tried to steal the amrta. (51)

But the Vișa-Kālakutta (Śiva's poison) caused the door suwuk to flee. For he was afraid of the god Śankara, the remover of Sin, who was always present in the temple. (52)

A pleasant sight was presented by the wishing-trees next to the âvarana, standing close together and instilling happiness, providing everything one wanted, just like the Pariyẫta tree, obtained in the chuming of the Milk Ocean. (53)

Near these gold wishing-trees stood a splendid pendapa made of pearls. Its floor consisted of sparkling, shining gems. This pendapa contained various objects for the worship of God, such as pearls, coronets, and sunshades; there were vãhana as well: miniature elephants and models of carriages, and instruments encrusted with jewels and pearis, the finest products of the ocean that had been chumed, and which had brought forth these splendid things. (54-55)

There were also temples made of gems. All their elements were perfectly arranged, and they shone and sparkled. These were the vehicles for those who did the churning; (the vehicles) with which they llew through the air were left outside (the inner walls). (56)

(Altogether) outside there was a high wall of white silver surounding the entire complex. It was comparable to the snake Vàsuki, recovering from the fatigue of churning the ocean. (57)

The gate of sparkling gems and red lustrous stones was comparable to the shining head gem (of the snake), while (the two) râkșasa acting as doorkeepers were comparable to its sharp, pointed, poisonous fangs. (58)

This was what the temple at Lankä looked like ... (59)'

There are several features in this description that deserve our attention.27 More than by the identification of the temple with Mount Mandara, I was struck by the emphasis on the myth of the Churning of the Milk Ocean. The whole

27. This is not the place to discuss Pocrbatjaraka's arguments for the identification of the temple complex described in the Ramayana Kakawin with Loro Jonggrang. For a further discussion of the correspondences between the OJR and the Loro Jonggrang inscription see Jordaan (1989:24-6, 19912:165, note 1). 


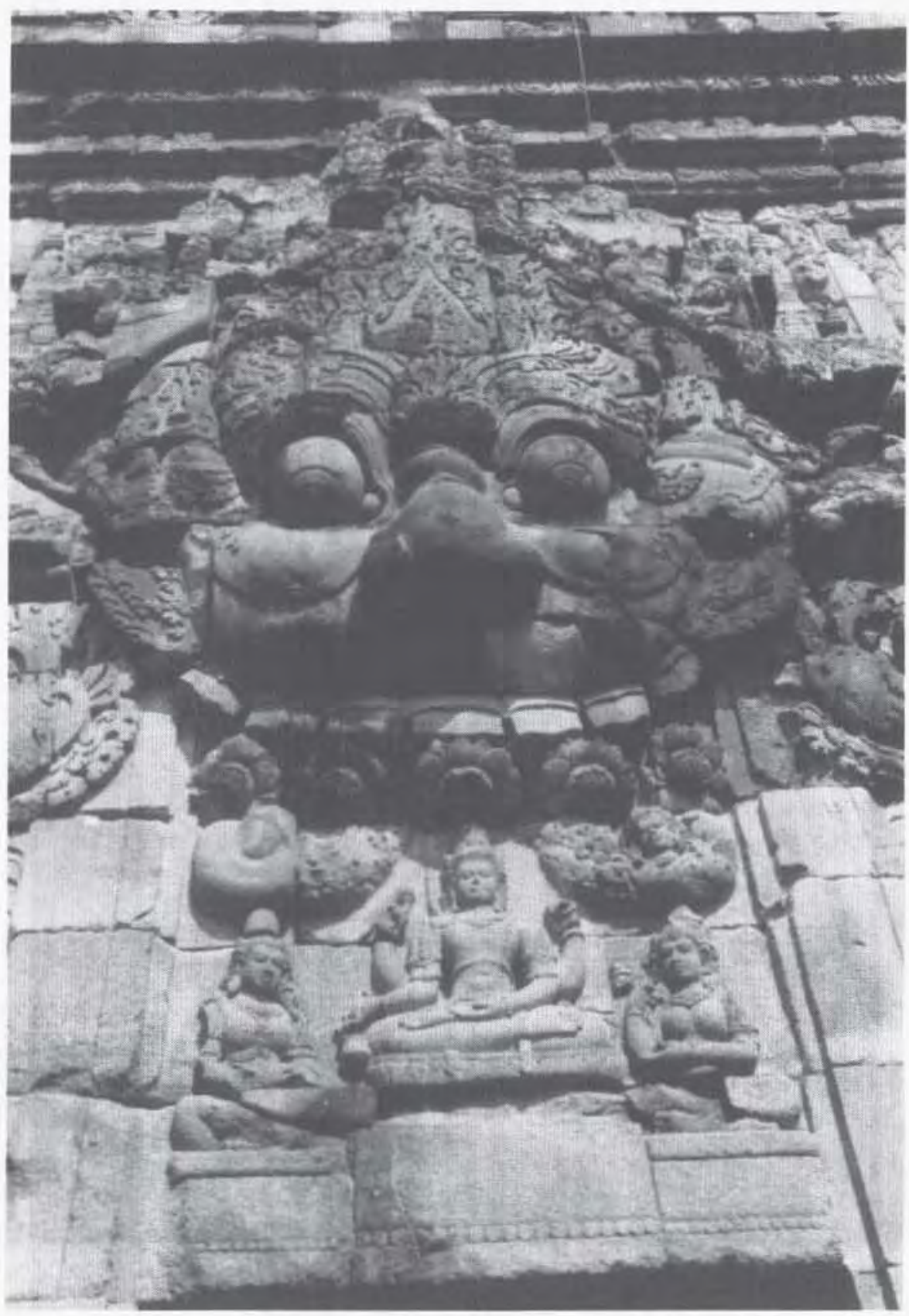

Photo 1. 'Their eyes were round, staring and protruding.' Huge Kăla head above the main chamber of the Śiva temple. (Photograph by the author.) 
description might in fact be seen as a metaphor for this myth. On the other hand, the poetic description seems so concrete, that one wonders if there is perhaps some other level of meaning, especially in view of Stella Kramrisch's comment on the fundamental importance of myths for temple construction, which I adopted as an apothegm for my research, viz.: 'The Hindu temple is the sum total of architectural rites performed on the basis of its myth. The myth covers the ground and is the plan on which the structure is raised.' (Kramrisch 1976:vii.) As an anthropologist, I saw in this statement a true recognition of the importance of the myth for those who believe in it. ${ }^{28}$

The comparison of the central temple area to the Milk Ocean is especially intriguing because of a possible connection with comments by Krom about the construction of this compound. His description led me to wonder if the central area might have been designed and used as an artificial tank or pool.

The first striking thing in this connection is the thickness of the inner wall enclosing the temple area. This wall was some two metres thick, which, according to Krom, made it wide enough not only for a balustrade, but also for a passageway around the terrace. 'Rampart' was the word used for it by Scheltema (1912:80). The foot of this wall was about 1.5 metres lower than the surface of the central courtyard, which makes it possible to describe the central temple area as a raised terrace. Krom described it in the following terms:

The large terrace may be mounted from all sides by a stairway, which has also remained undecorated. [...] It is 4.20 metres above ground level and is horizontal except for a slight incline to facilitate drainage. The drainage spouts were located only on either side of the entrance stairways, though [today] only the openings can still be seen. The fact of the small number of these openings, namely eight, for such a large area, as well as their small size, is probably connected with the sandy nature of the soil, which is highly pervious to water.' (Krom 1923a:451.)

Aithough I am not an expert on hydraulics, this latter seemed improbable to me in view of the likelihood of subsidence and the eventual collapse of the heavy temple buildings due to the more or less uncontrolled drainage of water through the soil. I furthermore wondered whether the soil was in fact as sandy as Krom would have us believe. ${ }^{29}$ The claim that the soil was highly permeable to water

28 For the significance of the myth in temple construction on the mainland of Southeast Asia, the reader is referred to Heine-Geldern (1930, 1967:51). Van Liere's article (1980), with which I was acquainted at first only from Wolters (1982:89), provides important points of departure for a comparative study of the 'holy water' theme in Southeast Asian temple architecture (see also Jordaan 1991a:176; Stargardt 1992a, 1992b; Christie 1992; Klokke 1993:150-2).

29 I was not successful in obtaining more exact information on the composition of soil in the temple area. Soekmono (1985:688), who demonstrated the use of mud to fill holes and crevices in the inner walle of the Vișnu and Brahmā temples, cryptically observes that the 
could not be confirmed, either ${ }^{30}$ On the contrary, I was struck during one of my first visits to the temple complex by the strange fact that the labourers working in the area did not just throw away the water they had used in some corner to drain into the soil, but instead let it drain away through the spouts or pumped it over the wall using plastic hoses. I furthermore remembered some casual comments about drainage problems in the annual reports of the Archaeological Service (compare Bernet Kempers' report (1978:102), referred to in section 3).

Whereas Krom seemed amazed at finding so few drainage spouts, considering the size of the central compound, I now contemplated their possible function in the design of an artificial pool or tank. The smallness of the holes of the drainage spouts, which was not reported by Krom, led me to believe that perhaps they had never been intended to serve for the normal drainage of the compound. It seemed more likely that they had really been meant to function as outlets of some basin or pool that could be sealed or closed with stoppers. Furthermore, if the inner wall did in fact serve as an embankment for an artificial water reservoir, this would explain the absence of ornamental reliefs on it. Hence, this lack of ornamentation can no longer be used as evidence that the temple structure had not been completed, as was suggested by Krom. ${ }^{31}$ Even so, Krom was very well aware that there was something special about the construction of the central temple area. This is evident from his comment that during the last period of Central Javanese history, the solidity of the foundations was a matter of concern to the architects (Krom 1923a:488, 1923b:106). ${ }^{32}$

After establishing that the comparison with the Milk Ocean was not necessarily a mere poetic fantasy, I had to try to demonstrate that the compound

fine sand of which the soil seems to consist in reality is dried mud'.

3o Ir Willem Hoogmoed, a soil tillage expert from the University of Wageningen, pointed out to me that from the start of the construction of the main temples, the soil of the central temple area must have been so intensively walked upon and polluted with construction materials that a degraded, so-called slaked or sealing surface developed that became impervious to water. Obviously, there is no need to argue that the question of the permeability of the soil is of no relevance, if the inner courtyard was tiled (see Jordaan 1991b:71, note 6).

31 Moreover, I am not sure whether the presence of a double sub-basement in the main temples in the central courtyard, which Krom (1924a:468) considered to be a typical feature of Loro Jonggrang, merely served to strengthen the impression of their verticality, as Krom (1924b:106) and Bernet Kempers (1955:24) asserted, or whether we should also consider the possibility that the main temples stood in water.

12 The foundations were only partially exposed later. The excavations by the Archaeological Service 'revealed that the entire raised platform containing the Jarger temples was fortified by walls built of stones from the river. Although this is not certain, it is assumed that all this was meant to prevent the erosion of the soil by heavy rainfall.' (Oudheidkundig Verslag 1938:15.) The walls below ground level were intact and did not need to be altered in the course of the reconstruction of the temple complex (Bernet Kempers 1978:100). 
could indeed have functioned as an artificial water reservoir. The only point of departure I had at the time was the Loro Jonggrang inscription, which rather cryptically mentioned certain migratory birds, merchants, and village functionaries who come bathe [in the water], which allegedly gave magical protection (siddhayätra) and coolness or a 'blessing' (mahätisa) (see De Casparis 1956: 326).

It was tempting to connect this water with the hypothetical water reservoir in the main compound. In that case, however, I had to consider De Casparis (1956), who held a completely different view. Briefly, this was that 'within or in the immediate neighbourhood of the temples' there had to have been a tirtha (holy pool), though:

'It is, however, obvious that it could not have been inside the two complexes already known, viz. the "heart" of the foundation surrounded by its own wall and the anumoda buildings [candi perwara] supposed to have stood in rows around the central part. The presence of a firtha within either of these complexes would be astonishing, if not impossible. It seems far more likely that the firtha was outside these two groups of buildings.' (De Casparis 1956:306.)

De Casparis subsequently conjectured that a patch of land on the bank of the nearby river Opak, between the second and third walls of the temple complex, might have been the site of the sacred pool. His argument involved a brief discussion of the curious orientation of the third wall. In his ingenious explanation, the remaining parts of the southern and western walls of the third enclosure were said to indicate that these walls had met near the river bank. Possibly the main reason for constructing the outer wall in this way had been to conduct a small volume of the river water through the outer temple area (see Figure I with the plan of the temple complex). The alleged advantage of this would have been the easy access it provided to clean water for ablutions of the priests, cult objects, and the like.

A second advantage, according to De Casparis, concerned the use of the temporary dwellings and hermitages by priests, ascetics, and pilgrims - an idea first put forward by the colonial restoration committee (see Verslag 1926:36). A plausible explanation for the curious design of the third wall is the distinction it implies between the space reserved for the 'dwellings of the gods' (within the walls oriented to the cardinal points) and the space reserved for human habitation, where no exact orientation was considered necessary (De Casparis 1956:308-9).

In my view, the latter point at the same time provides the principal objection to this particular solution. While it may be true that the patch of land in question once had dwellings on it and perhaps even gave access to the river, it seems unlikely as a site of the tirtha alluded to in the inscription. The fact that the 
inscription speaks of siddhayātra and mahātisa in connection with bathing implies a prior sanctification of the water. From a symbolic point of view, this condition could not have been met in the profane spot indicated by De Casparis, that was reserved for hermitages and other so-called 'dwellings of human beings'. ${ }^{33}$

This contradiction led me to reconsider the possibility of the presence of a firtha in the immediate vicinity of the main temples, the dwellings of the gods. ${ }^{34}$ It goes without saying that water from this spot would have been regarded as thoroughly sanctified and as possessing all the supernatural qualities attributed to such water. Fortunately, the inscription itself yielded the information that supports the literal reading of the Ramayana Kakawin. One of the most salient points of agreement between the inscription and the Old Javanese Rāmāyana concerns the use of water. Both texts use the word tamwak, usually translated as 'dam'. ${ }^{35}$ Although De Casparis notes that the translation might be defended by reference to two passages in the inscription - one mentioning the beneficial effects of bathing and another the man-made change in the course of the river he thinks it more likely that the word tamwak in the inscription refers to the brick walls separating the different parts of the complex from each other. His main objection to the usual translation of the word was that the stanza in which it first occurs deals with temple buildings or the structures immediately connected with these (1956:322), which is precisely the interpretation I sought to prove.

The dam-like construction of the inner wall fits in perfectly with a conception of the temple area as a physical representation of the Milk Ocean. In connection with the aim of this construction, I characterized Prambanan as a 'holy water sanctuary' in which, through a re-enactment of the myth, holy water was produced. ${ }^{36}$ I believe that now, instead of 're-enactment', I would prefer Mircea

33 Obviously, the same holds for Tlaga Lor, an ancient pool in a nearby village that is still used as a bathing place by the local people (Professor Boechari and Pim Grijm, personal communications).

34 Noteworthy in this connection is Leemans' casual remark that 'in order to get a good idea of the design and construction of the Prambanan temple group, one should imagine both a pair of giant temple-guards at its gates and ponds within the inner encircling wall for ritual ablution' (Leemans 1853:25; note his plural 'ponds' (Dutch: vijvers)).

35 According to Gericke and Roorda (1901, I:704) tambak means 'dam', as well as 'fish pond'. In Zoetmulder's Old Javanese-English Dictionary (1982:1916), tambak is glossed as 'wall, dike, dam, or fence', while Winter's and Ranggawarsita's (1988) Kawi-Javanese Dictionary gives the synonym bendung(an), which also means 'dike or dam'. In modern Indonesian, tambak still denotes an earthen dam, embankment or fish pond made by damming (Echols and Shadily 1990:546).

36 Following Stutterheim's characterization of the stone at Sirah Kencong as a 'Holy water machine', I originally intended describing the Prambanan temple complex as a 'holy water 
Eliade's term 'cosmicization', denoting a consecration which reproduces the paradigmatic work of the gods (Eliade 1976:18-31). It is perhaps superfluous to point to the possibility that this ceremonial repetition may have been something very special, and that the water with its magical qualities was produced by inundating the courtyard only on holidays or on other momentous oecasions. ${ }^{37}$

It was not of course possible to establish immediately which of these two views on the location of the tirtha is the correct one. One way of deciding this would be by flooding the central courtyard with 10 centimetres of water. Considering the impracticality of this, however, I decided to try to gather additional information from other sources.

Such a source that came to my attention was Aichele's neglected article (1969) which deals primarily with the dating of the Old Javanese Rāmāyana, but which also contains important corrections and emendations of De Casparis' authoritative reading of the Loro Jonggrang inscription. Aichele confirmed the value of the mutual interpretability of the two texts and suggested a correction with reference to the commemoration of the day of King Rakai Pikatan's death, the historical implications of which were discussed above. In addition, however, Aichele pointed out that the change to the course of the river mentioned in the inscription was to guide the water not to the temple complex, but rather away from it. ${ }^{38}$ Aichele expressed doubts as to whether the second and third walls existed at the time of the change in the course of the river and was inclined to wonder if this measure had perhaps been taken in order to make a further extension of the temple complex possible. If he is right, there can of course be no question of a tirtha being located in the spot indicated by De Casparis. Aichele also noticed some errors in the translation of the stanza in which the first inner wall is mentioned, namely that of the words těas and téasaturusnya. These had been translated by De Casparis as 'heart' (the central buildings) and 'the heart (of the complex) with its own wall', respectively. Aichele was not able

supply station', but finally followed G.J. Resink's advice, opting instead for the label a 'holy water sanctuary'.

37 In a personal reaction to my hypothesis, some archaeologists objected that they found it difficult to imagine how the officiating priests could have reached the main temples, except by wading through the shallow water. To me, this objection seems rather ethnocentric, as it ignores the fact that the water concerned was not ordinary water but 'holy water' of a high magical potency.

38 Crucial in this connection is the translation of the conjunction apan, which may mean either 'so thatin order to' or 'because' (Aichele 1969:146). Many years later the Indonesian epigraphist Boechari independently arrived at the same conclusion as Aichele (Boechari 1978:14,20, personal communication). Technically, the diversion of the river might have been intended to protect the temple site from erosion; I wish to thank Peter Buurman for the suggestion. 
to trace this metaphorical meaning of the word těas in the Old Javanese literature and it seemed possible to him, judging from other archaeological and ethnographic reports, that těas referred to a foundation stele (German: Garantiestein, Stiftungsstein) used as a magical protection of a building site. ${ }^{39}$ Hence he concluded that teasaturusnya referred to a fenced-in foundation stone, rather than to a wall surrounding the central courtyard (Aichele 1969:156-7).

However that may be, the same stanza points to the presence of a tamwak, or dam-like wall, if we stick to the usual meaning of the word. Unfortunately Aichele did not discuss the nature of this wall. He only spoke of a 'wall that was intended to surround the temple courtyard'. One could conjecture that, when translating the line, he would have discovered the true nature of this wall, considering that he characterizes the temple, with reference to the relevant passage in the Ramayana Kakawin containing the description of the temple and its surroundings as a 'symbolic representation in stone of the legend according to which the gods churned the Milk Sea in order to obtain amrta, the elixir of life' (Aichele 1969:161).

Further evidence, albeit circumstantial, of the dam-like qualities of the inner wall was provided by a description of a temple complex in the Śiwarâtrikalpa, an Old Javanese poem of East Javanese provenance (Teeuw et al. 1969). My identification of this temple complex with Prambanan was based on several striking correspondences which need not be repeated here, except for the enigmatic word bwat-dhantĕn, which I took to be a variant of bwat-rawi ('constructed pool'), which I then assumed to refer to the central courtyard of Prambanan (Jordaan 1991b:69). This interpretation must remain tentative because the translators of the poem do not explain why they dismissed this translation as 'not very probable'. They opted for an interpretation of bwatdhantěn as a supposed variant of bwat-halu, and hence a reference to 'lingapavilions', whatever these may have been.

Completely independently of this speculative reading of the relevant passage of the Siwarâtrikalpa, my 1991 article provided the opportunity to delve deeper into the important question of the feasibility of flooding the central courtyard. Initially I came up with two alternatives, namely diverting water from the nearby river by means of conduits made of bamboo or other materials ${ }^{40}$, or

39. See also Zoetmulder (1982:1969) who glosses těas (twas) as 'the sacred (border-)stone'. 40 Although it is no longer possible to prove this, one cannot exclude the possibility that in the case of this alternative the third wall served as a support for the conduits. This might well have been the high wall of white silver surrounding the entire complex [...] comparable to the snake Vãsuki' (Poerbatjaraka 1932:164), which Soewito Santoso renders as 'there was a canal winding upwards, with banks made of white silver. It looked like the dragon Basuki'. 
collecting rainwater. The idea for a third possibility, that of carrying the water in, occurred to me, thanks to a suggestion by G.J. Resink.

These alternatives and the technical features of the pool were put to Bill Hansen, a qualified hydrologist. From his analysis I reported that:

'Based on the height and thickness of the stone wall surrounding the courtyard, it was his opinion that there seemed to be no structural problems with the temporary storage of water within the central courtyard, provided leakage could be controlled. The problem of water collection needs further investigation; subject to the river level in relation to that of the courtyard, and transport distance, this could have been done by diverting the nearby river at a higher level and leading it to the temple by means of bamboo conduits or earthen channels. Manual water-carrying and collection of rainwater were possible supply alternatives or at least methods of augmenting the supply. Based on the data given by Bernet Kempers (1955) with respect to the size of the inner courtyard and of all the buildings within it, one can roughly calculate the total volume of water needed to fill the inner courtyard to the depth of ten centimetres, at 1000 cubic meters approximately. With this volume it would have been feasible to keep the pool topped up by manual water-carrying. given that manpower was no problem and that the river was nearby. For example, in one week 150 men, each carrying thirty loads of thirty $\mathrm{kg}$ a day, could raise the water [level] by ten centimetres.' (Jordaan 199Ib:70.) ${ }^{41}$

At this stage I can only add one remark to this, relating to the presumed leakage problem. I do so on the basis of photographs I took of the temple area in 1992. Although the one reprinted here is a little blurred, there are three shallow handdug ditches discernible, which converge on one side at a gravel border covered with sods around the foot of the Śiva temple. At the other end they run into holes in the dam-like wall surrounding the temple area. Two of the ditches can be seen to disgorge into existing outlets on either side of the western gateway, whereas the third one ends in a large, newly made hole in the inner wall.

According to labourers working on the temple site, these served to improve the drainage, heavy rains and the muddy pools these leave behind allegedly posing an obstacle to visitors. Apparently they were inadequate for the job, as

According to IJzerman (1891:39), one of the few persons to have seen its remains, the third wall was hollow. On the other hand, his plate XVII, fig. 67, shows an underground waterconduit made of stone running from the northern part of the third wall right into the temple complex and out again, skirting the central temple area (reproduced in Fig. 1). See also $O V$ 1931-1935, and the photographs OD 7760, 11403-4 showing this conduit and associated culvert.

41 This depth of ten centimetres is hypothetical, but it matches the 55-centimetres height of the thresholds in the gateways which give access to the inner courtyard. It seemed to me that this would have been more than enough for the priests or pilgrims who were allowed to enter the area to be able to ritually wash their feet in, as well as for the demands of the myth of the Churning of the Ocean of Milk, on which the temple is based, to be met. The number of men needed for carrying this amount of water is, of course, also hypothetical. In practice. far more people may have been engaged in this task to lessen the burden for the individual. 


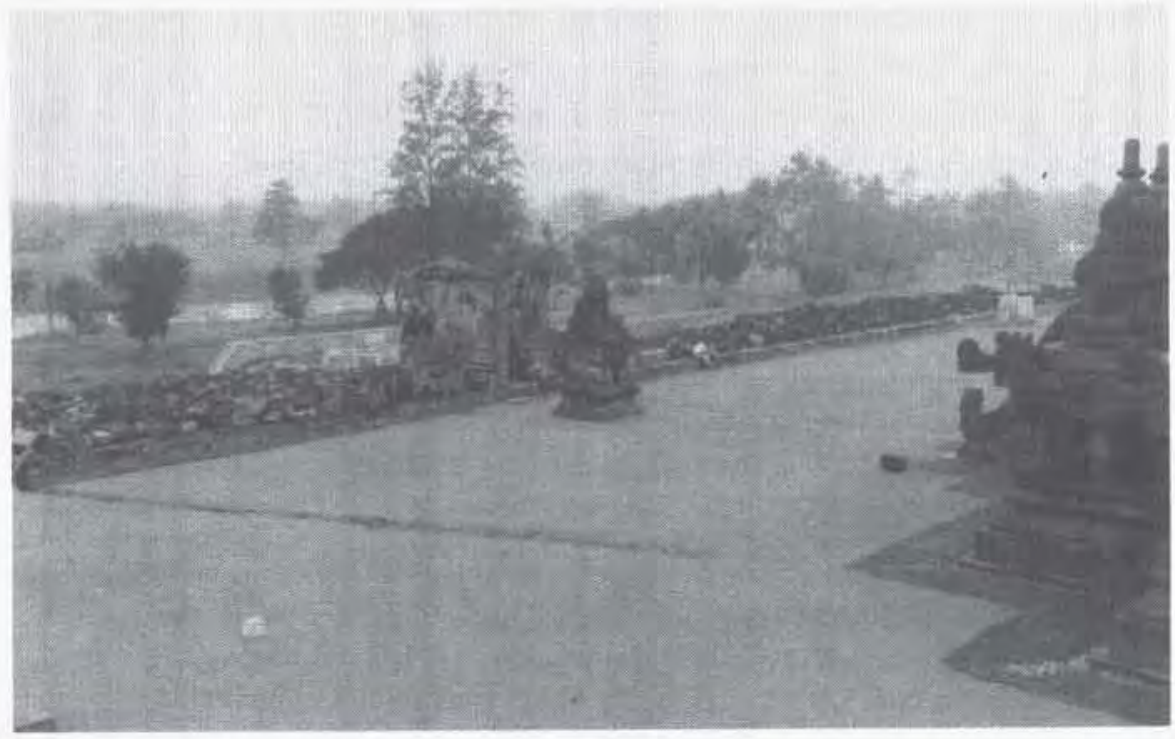

Photo 2. Hand-dug ditches located in the western part of the central temple area (photograph by the author)

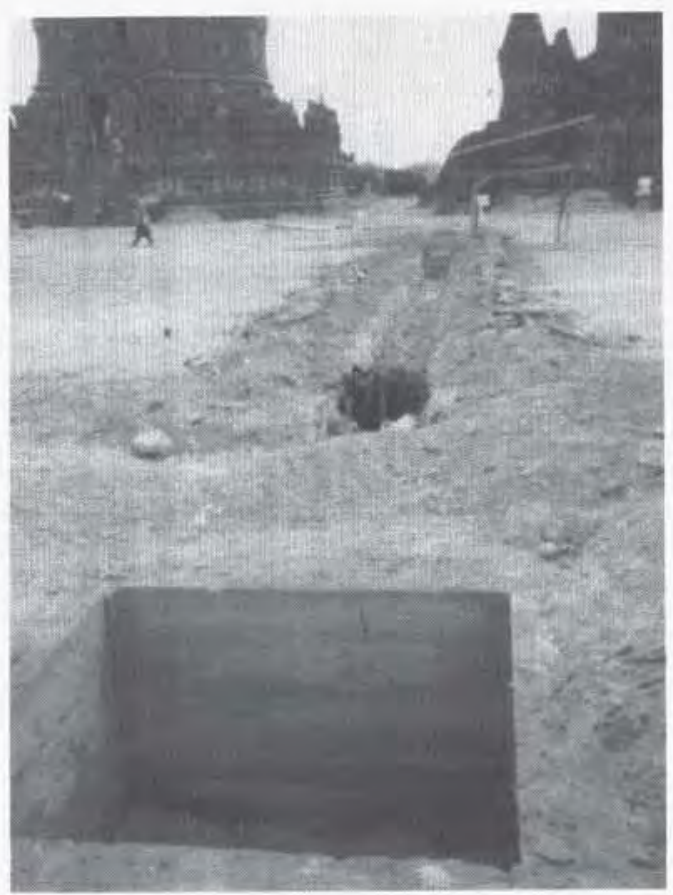

Photo 3. Recent drainage measures in the western part of the central temple area (photograph by Pia Hoekstra) 
the archaeological service later installed a network of concrete drainage channels, which converge on no fewer than twenty larger and smaller drainage tanks distributed over the temple area (Laporan 1993; Jordaan 1995).

For us to be able to properly imagine the temple area as a symbolic representation of the Ocean of Milk, all these changes would have to be undone.

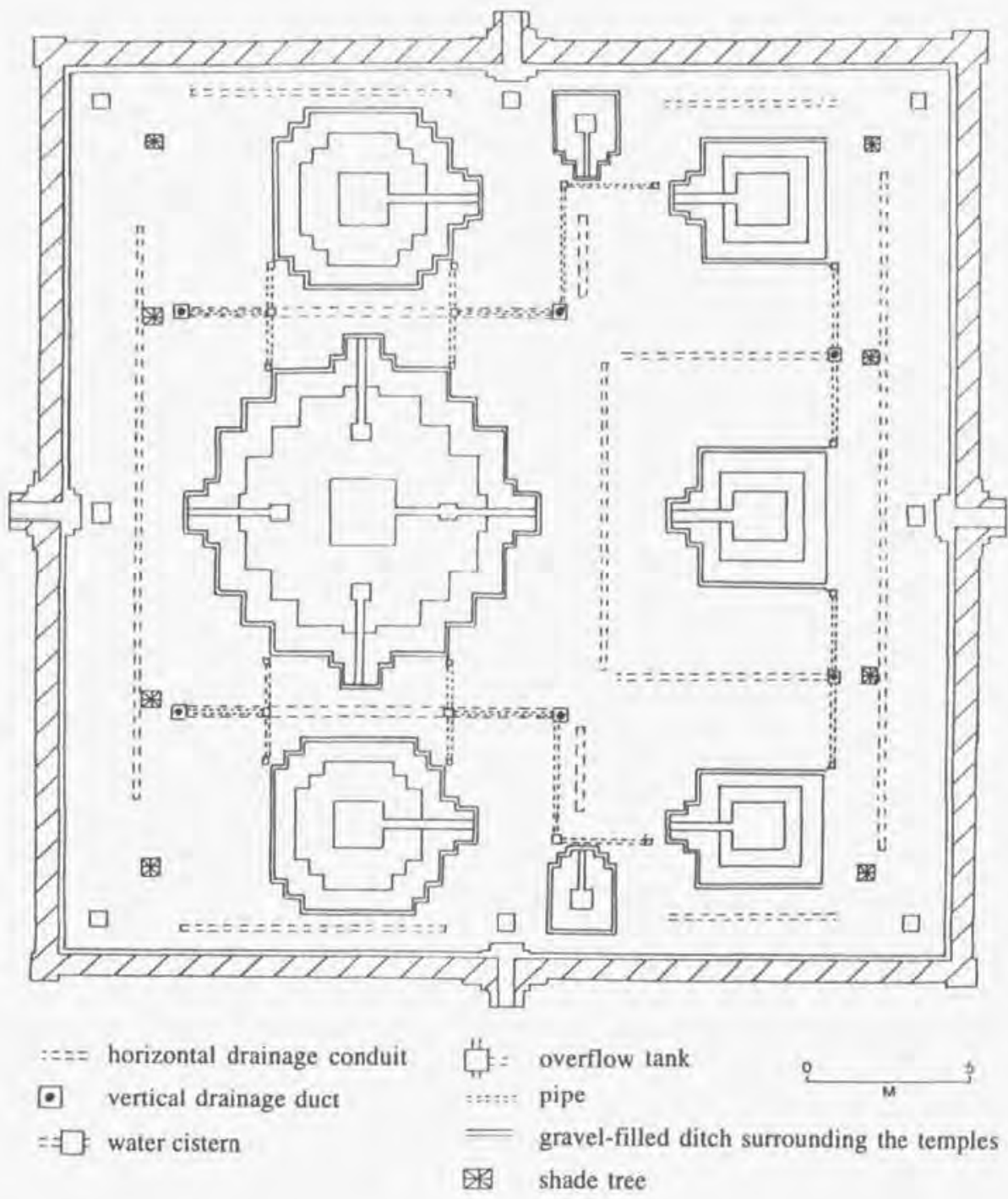

Figure 5. Recent drainage measures in the central temple area (Laporan 1993) 


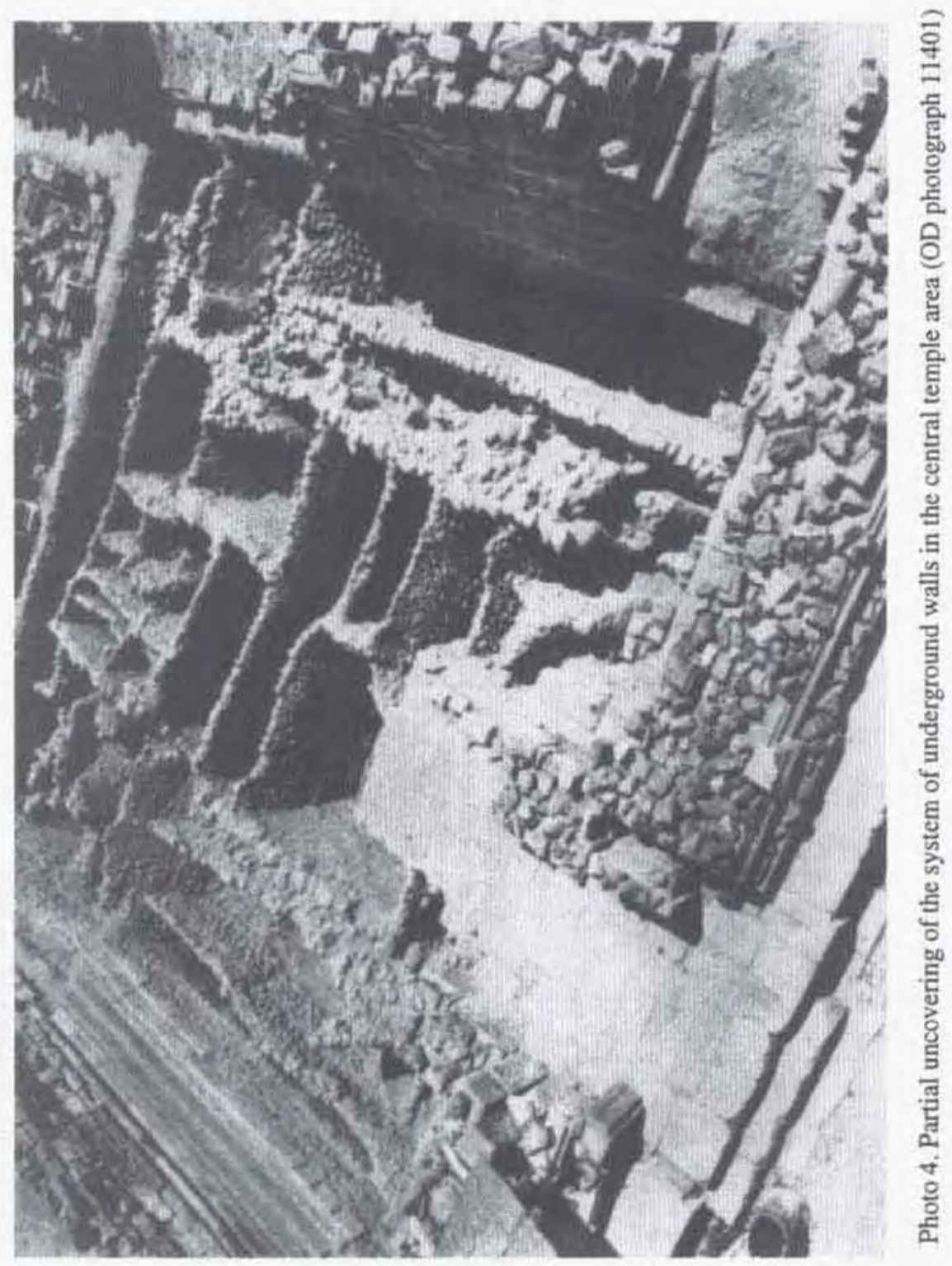




\section{Design, meaning, and sectarian sensibilities}

Whether or not the central temple area of Prambanan served as a reservoir for holy water, one cannot escape the conclusion that it was built according to some preconceived plan. For, even in the unlikely event that Aichele is right and only the Siva temple was erected in $856 \mathrm{AD}$, it remains an indisputable fact that it was built on a raised, walled terrace which must of necessity have been constructed earlier. This must also have been Krom's conclusion, or he would not have emphasized the fact as strongly that the soundness of the foundations was a matter of so much concern to the architects in the final period of Central Javanese history.

The question must have continued to prey on his mind, because he suggested in one of his last publications that the system of what he called 'primitive' underground walls constituting the foundations of Loro Jonggrang's inner court might be the remains of an old-Indonesian [terrace] sanctuary (Krom 1939:200). This did not seem very likely to Bernet Kempers (1955:38, note 39), although the latter did not specify his objections.

The improbability of Krom's suggestion could be demonstrated, in my opinion, by arguing that the ancient Indonesian terrace sanctuaries were located in the mountains rather than on the plains. Besides, the erection of a Hindu temple on the remains of an indigenous sanctuary seems to me in contradiction with his own observations on the conservatism of Hindu worship. Krom had written:

'Even if one may note some typically Javanese features in the official sanctuaries, in general the religion tends towards conservatism, and non-Hindu elements of religious ideas and practices might, if anything, be expected in other places' (Krom 1923b:175; see also Bosch 1954).

Furthermore, it is highly questionable that the Hindu architects would have dared to take the risk of erecting these eight heavy temples on a foundation of which the bearing power and other technical qualities could not be determined exactly. According to Bosch it was precisely these architectural matters that the Javanese had always been weak in and therefore let themselves be guided by the instructions contained in the building manuals that their co-religionists had brought from India. ${ }^{42}$ The above arguments bring us to the matter of Hindu temple architecture, and presents us with the proper context for questions about design and meaning.

\footnotetext{
42 According to Bosch there was no reason to credit the Javanese with a talent for stonemasonry, in contrast with their evident skills in the decorative arts. With reference to their presumed architectural weakness he remarked that: 'It is fortunate for the Javanese that the construction of sanctuaries in accordance with the directions of the silpaśastra makes minimal demands on their architectural skills' (Bosch 1920b:151).
} 
In Hindu temple architecture, design and meaning are inextricably bound up together. Temple architecture is also described as 'consecrated architecture' (Dutch: gewijde bouwkunst), about which Bosch noted:

'Just as everything belonging to the gods is made according to rules laid down in the sacred scriptures, so too in the first place the sanctuary or palace of a deity must be built in accordance with his revealed will if he is to tarry there with pleasure. The choice of the site, the laying of the first stone, the placement of the deity's image in the inner sanctum, and [other] such acts should [all] be performed in accordance with definite ritual prescriptions. In a like way the selection of the materials, the measurements of the ground-plan, the construction, and the design and decoration of the structure itself take place strictly according to the rules.' (Bosch 1920:105-6; see also Vogler 1949:10-7; Kramrisch 1976.)

The books in which the rules have been distilled from the existing sacred texts and codified for the benefit of architects, sculptors and other silpin (craftsmen or artisans) are referred to as silpaśāstra. When these architectural treatises were compiled is difficult to determine, but Bosch suspected because of their many references to the Tantras as well as their hybrid character, that the silpaśästra did not assume their current form before the 8 th century AD. He believed that their component parts, however, were much older. It is likewise difficult to determine how many silpaśāstra there were in the past, although it is certain that different religious sects had their own books of instruction.

For the general reader it may be useful to pause for a moment to consider the degree to which craftsmen were bound to the detailed directives of the silpaśästra. Contrary to what might perhaps be supposed, the rules laid down in the manuals do not primarily serve an aesthetic purpose, but rather a functional one. The duty of the silpin is to construct ritually functional objects. By making a temple statue in accordance with authoritative rules, it was hoped that the deity worshipped would be induced to take up his residence in it and manifest himself to the faithful in the course of certain ceremonies or prayers aimed at persuading the deity to descend into the statue. An incorrectly constructed temple or statue will not be entered by the godhead, regardless of its aesthetic value, and thus would be worthless for use in religious worship. The negative effect of this will go even further. The treatises give warning time and again that a neglect of their authoritative rules will give rise to accidents and calamities.

It is clear that the restrained nature of sacred art has important consequences for the way in which it is to be studied and appreciated. It must be accepted a priori that nothing was superfluous or left to the personal discretion of the artist. The only freedom that was perhaps left to the architect and the sculptor was in the choice of the particular silpasasstra that they would follow, in accordance with the precepts of their sect. 
In view of the above, we must ask why the Prambanan temple complex as we know it today was built in the form of a terrace with main and subsidiary temples, with different areas separated from each other by walls constructed in different ways, and so on. The question of function and meaning presents itself in all the parts and on all levels. If we were to make an inventory of all the more or less explicit questions we would like to have answered about Loro Jonggrang on the basis of the existing archaeological descriptions, it would become clear that only a few of these concern the design of the temple complex as a whole, and that most bear on its separate parts, whether a number of structures clearly belonging together, or one or more reliefs.

This finding is not so startling if one remembers that Prambanan was discovered when it was an overgrown ruin and that its scale and specific structure were only gradually discovered in the process of excavation and reconstruction. Only after all its parts had been exposed did an appreciation of the complex as an architectural whole become possible. It has justly been observed that:

'the first thing that strikes one when viewing this group is its unity; it ruled out that initially only a part was designed for instance and later other buildings were added by coincidence. Design and ornamentation are the same everywhere, regardless of differences in execution.' (Krom 1923a:453.)

Nevertheless, one occasionally comes across statements in the literature that testify to an inadequate appreciation of the conceptions of the architects..$^{43}$ Take, for instance, Krom's own sympathetic discussion of Van Eerde's abovementioned view that Prambanan was a state temple and that a comparison with Balinese temples would enable us to give an explanation of the total number of subsidiary temples, which were believed to correspond to the number of quarters in the former capital (Krom 1923a:453). This would mean that the expansion of the complex would have had to more or less parallel the growth of the city and its population, as was indeed suggested by Pitono Hardjowardojo. who said:

'If more cult images had to be provided for, niches inside or outside the principal temple were added, or minor temples were added, standing separately within the boundaries of the temple enclosure. In this way a whole temple complex could be built. Loro Jonggrang is a good example of this.' (1967:12.)

43 Admittedly, I have made the same mistake when I suggested that after the expulsion of the Śailendras from Java the new rulers may have tried to execute the construction on a larger scale or in finer detail than was originally intended (Jordaan 1993:34). It may have been in finer detail but not on a significantly larger scale or structurally, since the architectural design was fixed previously and could not possibly be altered at will without endangering the whole conception. 
This must surely be incorrect. I agree with Stutterheim (1925:137) that in this way the grouping of the component structures of the complex would become rather arbitrary and that it would be quite a coincidence if the city had precisely as many quarters as there were small shrines constructed in neat rows around the central temple area. According to Stutterheim the number of these structures cannot be arbitrary and there must be other reasons underlying their construction. Unfortunately he did not discuss these other reasons any further, apart from expressing a vague suspicion that the temple complex was built according to some Puranic system. Neither did he name the temple complex in mainland Southeast Asia where similar rows of temples were found, whose meaning there might perhaps offer an explanation. ${ }^{44}$

As regards the meaning of specific components one is faced with the fundamental choice between an explanation primarily in terms of indigenous Javanese, or possibly general Southeast Asian ideas, and one in terms of Indian models. Prambanan offers numerous examples of the former, though the results of research in this direction have not so far been very convincing, or sometimes even dubious.

Besides the idea of the ancient Indonesian terrace sanctuary idea discarded earlier, I might draw attention to the question concerning the main entrance to the temple complex. The restoration committee's report informs us that Van Erp originally believed that the main entrance could not have been located on the eastern side, although he was aware that the entrance there must have been wider and more monumental than those elsewhere. According to Van Erp, the aesthetic argument that the temples would have looked far more beautiful against the background of Mount Merapi argued in favour of an entrance on the southern side. The way the existing roads ran also seemed to argue in favour of this. A circumstance that seemed to argue in favour of the location of the main entrance on the western side was the location of the large forecourt between the Trimürti temples and that side of the inner wall. The argument against the eastern gate being considered a main gate was as follows:

'After one has mounted the stairs there, one has a view of the rear of the three vähana temples. The Siva shrine is completely hidden by the Nandi temple. Furthermore, the axis of the stairs is more than 2 metres out of true vis-à-vis the central axes of the Nandi and Śiva temples.' (Van Erp as cited in Verslag 1926:16.)

The restoration committee's response to this, which we may suspect was influenced by Stutterheim, its secretary, was as follows: 
In the Javanese view, there is nothing unsatisfactory about this mode of construction; on the contrary, it is significant, as after all, the vähana temples function as a kelir or screen, that protects Siva from mortal view, with respect to the main monument, in which the Mahädeva is enthroned. The main entrance to the temple is also located on the eastern side, and hence the eastern side must have been the "good" side from which to approach [the complex]. This is also indicated by the grander execution of the eastern approach. One notices the same thing in East Javanese architecture, of which Prambanan is a transitional example. The shift of the axis of the stairs relative to the central axes of the Nandi and Siva temples is a phenomenon that can be seen in the layout of the kraton even today.' (Verslag 1926:16.)

It is not my intention to call into question that the location of the main entrance was in the east; the proportions themselves are evidence enough for this. My objection concerns the suggestion that Javanese conceptions lay at the basis of the structure of the temple complex, and that the screen of the wayang (puppet) theatre and the layout of the kraton could be taken as indications for this. This not only ignores the question of whether both the wayang and the layout of the kraton may have been based on Indian models, but is also in contradiction with the fact that an eastern main entrance does not really fit in with general notions about space in Indonesia. The idea that positioning a building on the east-west axis should be avoided is far more common, because this is 'the way of the sun'. This applies not only to ordinary houses, but also to the royal palace, and it is the reason why most Javanese kraton are positioned on the northsouth axis (Behrend 1989). The shift of the axis of the gateway relative to that of the shrines, and the correspondence of this with the arrangement of the buildings of the kraton, is indeed striking and may involve this consideration. The definite answer, however, will need further investigation. ${ }^{45}$

The ground for the study of the architectural aspects of Hindu-Javanese temple construction, however, has hardly been broken. I only know of the early, exploratory study by Bosch (1920), which did not directly concern Loro Jonggrang, moreover, but aimed rather to make the idea of the use of silpaśasstra in Javanese temple construction more generally acceptable. ${ }^{46} \mathrm{It}$ is rather surprising that Bosch was successful in this endeavour, because he only had the text of one silpaśāstra, the Mānasāra, available to him at the time, and

45 That the mortal eye needs to be shielded from the sight of Siva requires some explanation. Furthermore, it is not reported whether this rule is also Javanese or whether it is of Indian origin. This claim should have been supported with ethnographic examples or with quotations from Hindu dogma.

46 As regards Central Java, Bosch's pioneering research was only followed up with Van Blom's (1935) study of Candi Sojiwan. Separate mention should be made here of the work by Van Erp (1909. 1943). whose architectural and iconographic research is in a class by itself. 
TJ. LARA DJONGGRANG ZUTRLLIR HOEKT ORENTJE NUST oos reluke trap VW DE. CRWA - TEMPEL SCMAaL
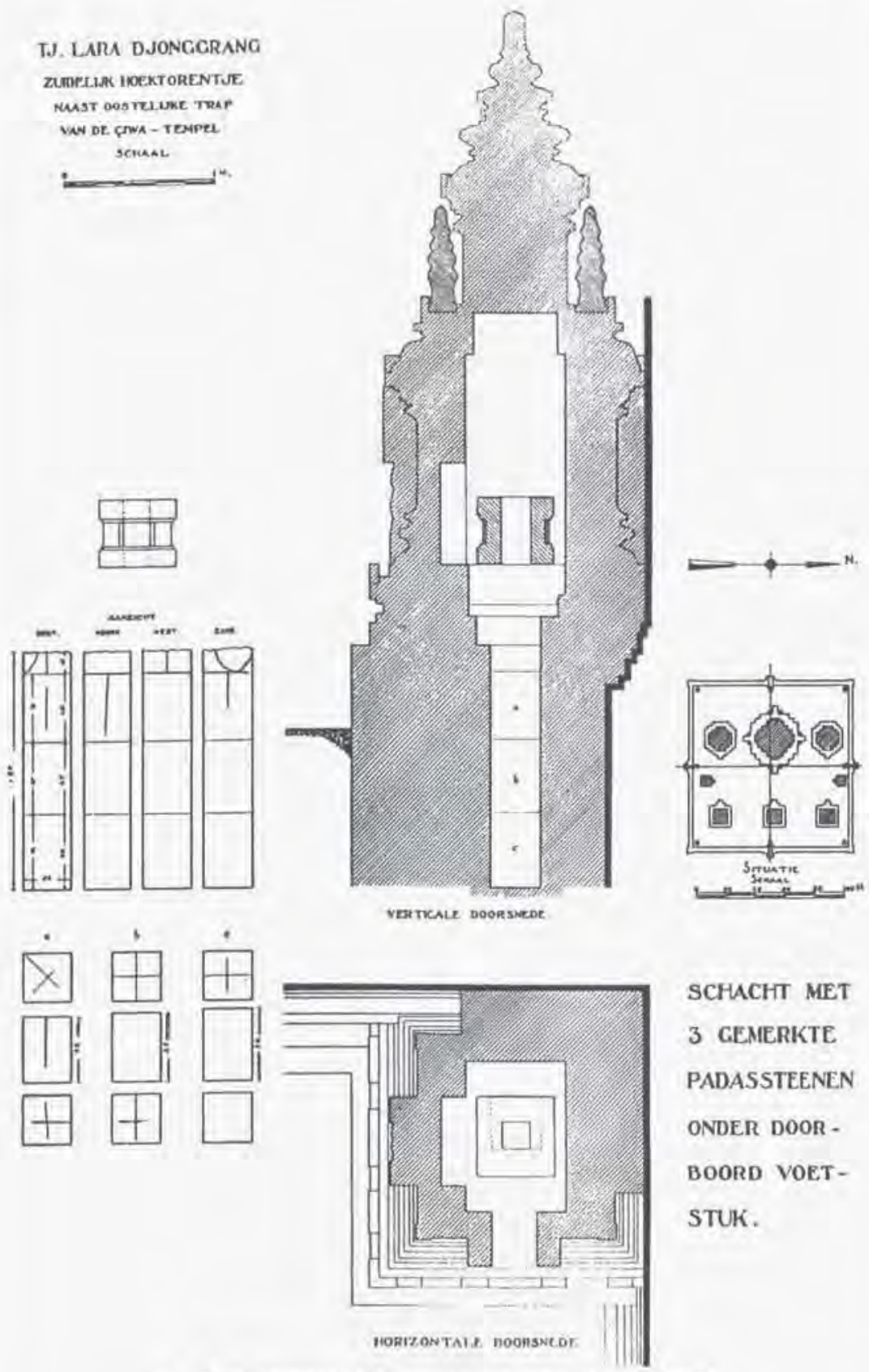

SCHACHT MET 3 GEMERKTE PADASSTEENEN ONDER DOOR BOORD VOET STUK.

A. Lorodjonggrang. Hoektorentje met gemerkte padassteenen.

Figure 6. OD drawing showing the geometrical centre of the temple complex (reproduced from Oudheidkundig Verslag 1938:6) 
this was then only known in an incomplete and corrupt form. Furthermore, it was a treatise that had originated from and was used in South India. As we now know, North Indian influence, specifically that of Nălandā and Bengal, was far more important, at least during the Śailendra period in Javanese history, when Borobudur and Prambanan were built. Bosch's conclusions were twofold. Although the number and the nature of the differences between the Mãnasāra and Javanese art proved that the Mānasāra could not have been the principal text by which the Javanese architects let themselves be guided, the correspondences that were found, on the other hand, were so many and so conspicuous that there could be no doubt but that artistic prescriptions of a similar kind must have been known to and used by them.

This is where matters still stand. Interest in this subject has both increased and become more solidly founded since, especially in India, as is evident from the now classic study by Kramrisch (1946). However, the same can hardly be said of Java, and some of the arguments that are advanced with respect to Prambanan are still no more than outright guesses.

Take, for instance, the assertions about the function and meaning of the arrangement of the eight candi kelir along the inside of the first enclosing wall. If one were to draw lines between them on a groundplan, these lines would be seen to converge at a point southeast of the main stair of the Siva temple. This point turns out to coincide with one of the eight corner turrets located on either side of the four stairways. Differently from the seven others, however, this particular corner turret is open in front. In the space inside it there is a pedestal with a hole through it, and with beneath it a column formed by three so-called parallelepipeds on which fine lines are drawn, indicating the geometrical centre of the area (Oudheidkundig Verslag 1938:6-7).

Bernet Kempers rightly observed that the statue of Śiva in the main chamber of the Śiva temple, which is the sacred centre of the complex, is therefore not located in the geometrical centre of the complex, but rather just northwest of it. He notes that this eccentric position of the religious centre may also be observable in various other shrines in Java, as well as elsewhere. In this connection he refers to Indian texts, according to which it was forbidden to place statues or other important parts of a given structure at intersections as these appeared in the diagram on which the design was based. Unfortunately he does not say which texts mention this fact, but only refers in this connection to studies by $\mathrm{R}$. von Heine-Geldern (1930) and Kramrisch (1946) without mentioning any page numbers.

The same is true of the ideas about the significance of the eight candi kelir which correspond in form with the corner turrets next to the stairways. One of the archaeological reports speculates that they 'probably served to magically 
close [openings at] dangerous points (gateways, corners, and the like) [...]. They may be regarded as niches for offerings to the divine guards of the gateways.' (Oudheidkundig Verslag 1936:5-6.) It is still not clear whether this hunch is correct.

There is also speculation about the subsidiary temples between the first and the second enclosing walls. Aside from their correct number, the question is how their arrangement should be interpreted. Does the number eight have special significance here, this being the constant difference in their numbers if one moves from one tier of temples to the next: $44,52,60$, and 68 , respectively hence making 224 temples in all. Or is there some other system? Consider, for instance, the regular increase in the total number of entrances to the subsidiary temples, which J. Dumarçay apparently considered important.

The shrines on the diagonal lines have two entrances; for example, the shrine at the north-east corner opens to the east and the north. So that [from] whatever side one looks at, the first row has twelve doorways, the second fourteen, the third sixteen and the fourth eighteen; as a result of this arrangement there are a total of sixty doorways opening onto any one side. As the inscription says, "beautiful were the numbers of small buildings".' (Dumarçay 1978:57.)

The significance of this exercise escapes me. Going by the way in which the inscription is formulated, I would think that what matters is the number of the buildings rather than their entrances. Furthermore, the number of entrances may just as easily be divided into groups of eight. Thus every tier has four corner temples, located on the diagonal lines, each having two entrances. The total number of corner entrances in any given tier is therefore eight. Moving from one tier to the next, the number of temples situated between these corner tempels increases from 10 , to 12,14 , and 16, the latter number again being a multiple of eight. This may seem like a meaningless game with numbers, but it is not. The curious preference for the number eight among the builders is also found elsewhere, for instance in the central temple area, where we find eight main temples and the above-mentioned candi kelir and corner turrets. Eight is also the number of the waterspouts in the inner wall, there being two next to each of the four gateways. Further, there are the reliefs belonging with the eight guardians of the primary points of the compass (astadikpäla) and the eight unidentified deities of the points between these. Though one may note this preference, unfortunately it is not yet possible to explain it. 47 Without further

47 On further investigation of the literature one will readily discover other octads, indicating the special significance of the number eight in Hindu-Buddhist thought, such as the eight cemetries in Tantric rites, the eight Siddhānta Maheśvara, the eight Bodhisattvas who constitute the Nirmakaya, the Eight-fold Path in Buddhism, and so on. Little can be learned Irom Walker's remark that eight is 'a deeply mystical number; the key to the fatality behind 
information from the silpaśästra about the system that was followed in the construction of Prambanan, we can only guess at the meaning of this.

In connection with the striking preference for the number eight, it may also be noted that the identity of the Śaiva sect that was responsible for the design of Prambanan is a neglected subject, especially in comparison with the interest in the identity of the founder-king. As far as I know, only Sarkar (1967) made a remark about this in passing, positing that the Śaiva worshipers at Prambanan might have belonged to the Pāsupata sect rather than to the Siddhānta school, as has sometimes been claimed (see, for instance, Lokesh Chandra 1967:8).

Although Sarkar may be right in doubting whether the Śaiva-Siddhānta school was strong enough in the eighth century 'to lay the theological matrix of the Prambanan complex', the influence of the Pāsupata sect still remains to be proven. We know of only a few Pāśupatas outside India. Travellers' reports by Chinese Buddhist pilgrims, such as Hsüan-tsang (Xuanzang) and I-ching (Ijing), mention the presence of Pāsupatas in Cambodia and ancient Java. H. Kern (1917:137) cited Julian's translation of Hsüan-tsang, which said: 'At the foot of the mountain one sees the temple of the god Ta-tseu-tsai [or Grand Master] (Mahešvara) where the heretics rub themselves with ashes (the Pāsupatas) and where they respectfully bring their sacrifices.' I-ching also referred to 'Po-choupo-to' (Pāsupatas) who smeared themselves with ashes and worshipped Maheśvara. The recurrent references in Old Javanese inscriptions to the socalled pañcakuśika or Five Kuśikas - Kuśika, Garga, Maitri, Kurusya, and Patañjali - may also be connected with the Pāsupata sect, since Kusika is the name of one of the disciples of Lakulisa (alias Lakulin), who is assumed to be the founder and systematizer of the Pāssupatas in India. It is certain, therefore, that the Pāsupata sect was known in Java at about the same time as in Cambodia (see Bhattacharya 1955; Coedès 1968:113).

In my opinion this does not mean, however, that this sect can be associated with Loro Jonggrang without further consideration. Surely, the mere mention of a temple at the foot of a mountain is too vague for anyone to conclude that it refers to Prambanan. Furthermore, the simple tribute to or invocation of the Five Kuśikas in imprecatory formulas in a relatively small number of Javanese inscriptions (eight out of the total of one hundred and twelve inscriptions discussed by Sarkar 1972), the earliest of which dates from $860 \mathrm{AD}$, does not warrant the prominent position for the Pāsupatas in the design of Prambanan that is accorded to them by Sarkar.

events' (1968:137). It is interesting to note, however, that eight is așa (astau) in Sanskrit, a dual form - the only dual form in counting in Sanskrit - which may well have a bearing on the issue (personal communication Professor Lokesh Chandra). 
In a recent publication (Jordaan 1993) I tried to establish a connection between the temple and another Śaiva sect, the Kāpālika. My suggestion was based especially on IJzerman's (1891) finds of human and animal skeletal remains. According to IJzerman, these could be taken as an indication that the temple complex had been built by a Tantric sect. In his article he referred to studies by Colebrooke and Coleman, who reported animal sacrifices in honour of the goddess Kăhi. Unfortunately, these admittedly rather vague references to Indian Tantric practices were subsequently neglected in favour of the funerary theory, which was then in the ascendant. There were two reasons for this.

In the first place, most scholars before the Second World War were convinced that this kind of Tantrism in the Central Javanese period was marginal and was confined to isolated cases of minor sects living in mountainous areas. Although it was known that the Mahāyāna Buddhism of Śrivijaya was infused with Tantrism, the scholars of the period did not extrapolate this fact of Tantric influence to the Mahãyanna Buddhism of the Śailendras of Central Java, mainly because the nature of the relationship between the two Buddhist kingdoms during much of the Central Javanese period was unclear. In the absence of earlier evidence, it was assumed that a full-blown Tantrism only became important in Java during the East Javanese period, which lasted from the early tenth century to the fifteenth (Krom 1931:189, 220; Moens 1924; Schnitger 1934). Instances of Tantrism dating from the Central Javanese period were usually belittled, in that they were either referred to as 'notions that were related to or to result in Tantrism' (Krom 1931:222) or as 'mildly' Tantric phenomena (see Bosch 1961:488).

One important factor in all this was a negative view of Tantrism, which was considered to be identical with demonology and the sinister practices of sorcerers, or black magic. An association of Tantrism with 'classic' monuments such as Borobudur and Prambanan was simply inconceivable (Krom 1927, II:327; Pott 1956:58). It should not surprise us, therefore, that in regard to the interpretation of Loro Jonggrang's animal and human skeletons something that is anything but unusual in the case of intellectual dilemmas took place: the matter was avoided, its relevance denied, or the evidence twisted.

Avoidance is the easiest of these reactions and it explains the silence in the recent archaeological literature about the animal sacrifices and the skeleton. Denial of the matter is less easy and rarer. An undoubtedly unintentional example of this is provided by Bosch, who dismissed the question of the prescriptions for some Vedic offerings, including human sacrifices (purusamedha), as an academic question, saying: 'One can assume that such sacrifices never actually took place but can be considered as pure fantasies on the part of "learned" Brahman priests' (Bosch 1920:142, note I). 
As allegations of distortion, suppression or misrepresentation of facts are not light allegations, they require careful substantiation. Therefore I will first review the treatment by the few scholars who mentioned the contents of the temple pits of Loro Jonggrang of the skeletal evidence yielded by these and hold this up to the facts as they are known to us. Krom mentioned both the human skeleton and the animal remains, but made no further comment, simply repeating Uzerman's observation that 'clearly none of the shafts, without exception, were dug [as pits], but that the necessary space was kept open in the base [of the foundations] during the construction [of the temples]' (Krom 1923a:486; see IJzerman 1891:69). Apparently no one gave any attention to IJzerman's additional finding that 'in all the temples the closing of the shafts was begun from the base of the foundations', which, as I see it, implies that the deceased cannot have ended up in these shafts by accident or as the result of a crime. The only possible conclusion thus must be that these are cases of deliberate burial, very likely of human sacrifice.

Whatever the reason for this oversight may be, the Prambanan skeleton hardly received any attention after Krom. The only time it was mentioned again, to my knowledge, was in Stutterheim's (1935) review of Van Blom's monograph on Candi Sojiwan, a temple located a few kilometres from Prambanan. This was prompted by Van Blom's (1935:13) mention of the discovery of human skeletal remains in the grounds of this Buddhist sanctuary, which probably dates from the first half of the ninth century. Stutterheim, consistently with the ideas of his time, did not refer to a possible Tantric Buddhist background of this phenomenon either. Instead he pointed - and to my knowledge for the first time - to the Javanese folk tradition concerning human sacrifice during the execution of important construction projects. What strikes one here, aside from the rather casual mention of this, in a footnote, is Stutterheim's unusually cautious formulation, leaving ample room also for coincidence. Stutterheim writes:

The author [Van Blom] reports the discovery of the remains of a skeleton. I recollect that to the southeast of the so-called Nandi temple at Prambanan a skeleton was found as well (Photo OD 11192). Obviously we can draw no conclusions from this correspondence and must leave a lot of room for coincidence. Nevertheless, it is desirable to be careful here, inter alia with respect to the Javanesc culik-belief, which presupposes human sacrifices in connection with large construction projects.' (Stutterheim 1935:84, note 1.)

It will not have escaped the attentive reader's notice that the remains indicated by Stutterheim cannot have been the same as those found by IJzerman in 1885 , because the latter were not found to the southeast of the Nandi temple, but rather in the temple pit in Candi B, which is located to the north of the Nandi temple. Moreover, the later discovery of a skeleton was not made in a shaft 
underneath the base of a statue, but in the central temple area, at least as far as can be inferred from the extremely summary account accompanying the abovementioned photograph. In the Oudheidkundige Verslagen 1931-1935 relevant data, such as concerning the sex and the supposed age of the deceased, as well as the probable cause of death, unfortunately are lacking. This is a truly proverbial disappearance of a skeleton in the archaeological cupboard. It was, in fact, not the only time this happened. Soekmono (1974:71), in a similar vein, claimed that there was uncertainty about the provenance of the skeleton that was found in Candi Sojiwan. If there is any uncertainty, however, it is about the charred bones that were found in the pit of a now vanished subsidiary temple, about which the Yogya Archaeological Society did not report 'whether they were of animal or human origin, or both' (Van Blom 1935:109). As for the remains that were found in the north-western corner of the temple courtyard, however, Van Blom (1935:13) speaks explicitly of 'someone who died there', whose 'skull is in fairly good condition'.

Besides the suppression of important evidence, there is also the question of misrepresentation of facts in terms of indigenous Javanese concepts and practices. Where Stutterheim referred to culik-beliefs in this connection, Soekmono was reminded of the still current village ritual of pendheman, involving the sacrificial burial of a buffalo's head on a new building site. My conclusion therefore was that both authors accounted for only part of the problem, while their evidence must be held inconclusive. Just as the the buffalo head could not simply be equated with the sacrifice of a dog or an ant-eater, so the sacrifice of a human being in the central temple courtyard of one of the most important Śaiva temple complexes in Southeast Asia could not simply be explained as a Javanese folk-belief. On the contrary, given the reputed conservatism of Hindu temple worship, I thought that the practice of both animal and human sacrifice in this sacred spot must have been emulations of Indian examples (Jordaan 1993:4).

As regards the Indian connection, the human skeletons in particular may provide an important clue for identifying the sect that officiated at the inauguration of the temple complex in $856 \mathrm{AD}$. In reiteration of my earlier statement, I would observe that it cannot be ruled out that this was the long extinct Kãpālika sect, which is known to have practised human sacrifice. Unfortunately, not much is known about the sect. The scant information that has been painstakingly collected by $\mathrm{D}$. Lorenzen $(1972,1989)$ is largely restricted to the Kāpālika and the Kālāmukha sects in ancient India and Nepal, while there are hardly any reports about them from Southeast Asia.

According to the archaeologist Hariani Santiko (1987:370, 1990), the Kāpālika sect was probably designated as Bhairava, the earliest written evidence for which dates from the East Javanese period. This view needs 
reconsideration. The animal and human skeletons found at Loro Jonggrang and Sojiwan furnish clear evidence of the practice of demoniacal or 'left-hand' forms of Tantrism during the Central Javanese period. ${ }^{4 x}$ Originating from different temples structures, these sacrifices also attest to the degree to which Hinduism and Buddhism had mutually accommodated and become rather alike. This evidence brings to mind the report of a Chinese pilgrim, Hsüan-tsang, about the objections which the Hinayāna monks of Orissa had towards the teachings of Mahãyãna, saying that this was not the Buddha's doctrine but a heresy. They also were reported to have said that the monks of Nālandā, the famous centre of Mahāyãna Buddhist learning, did not differ in any way from the Śaiva Kāpālika (see Kern 1888:156). Additionally, I want to draw attention to a casual remark by Bosch (Verslag Congres 1921:47) that 'a certain manifestation of Mañjuśñ is referred to as Bhairava' (see also Grünwedel 1900:100). This information seems to indicate that the influence between Tantric Buddhism and Śaivism was not one-sided. The early connections between Buddhist and Śaiva Tantrism, however, need further study. Mañjuśri in particular seems to offer a promising clue for further investigation, especially because of his once predominant position in the Buddhist mandala at Sewu-Prambanan.

Finally, there is the find in the mountains to the north of the Prambanan temple of a unique bronze skullcup, probably dating from the Central Javanese period (Stutterheim 1929c:14-5). It has rightly been noted that this object resembles Tibetan skullcups that are still used in Tantric rites. Such skulls are especially associated with the Kāpãlika, as are the triśulä (trident) and the large, flat and round earrings, that are worn by a large number of the deities depicted on Loro Jonggrang. Whether all this is sufficient evidence for a Kãpālika connection will have to be decided by iconographic and Tantra specialists, ${ }^{4 y}$

AR On the grounds of Candi Sambisari, to the west of Prambanan, remains of bones were found as well. Unfortunately, after the demise of the funerary theory, skeletons are handled rather carelessly in the reports of the Indonesian Archaeological Service. These only mention 'bones' (tulang-tulang) due to which it is not possible to determine whether the sacrifice concerns an animal or a human being (Mengenal Candi Sambisari n,d,:6). Wessing (1991:8) reports on the presence of a human skeleton near the Gunongan monument in North Aceh, a Meru-like structure that may pre-date the old Sultanate of Aceh.

49. In passing, I want to mention the remarkable discovery of an unfinished statue of Brahmā in the central courtyard at Prambanan. Both Jochim (1913:476) and Krom (1923a: 487) assumed that this had been there because of some technical flaw. In my opinion. however, it might well be connected with the myth in which Siva cut off Brahmā's fifth head, thus acquiring the status of Kapāleśvara, the divine archetype of the Kāpãlika ascetic (Lorenzen 1972:77-80). Although I realize that my interpretation may look improbable. Jochim's and Krom's explanation are, in my opinion, untenable. The plausibility of their ideas always depended on the 10th-century dating of Prambanan, on the eve of the transfer 
Further research on Śaivism in ancient Central Java is needed to verify the suggested Tantric and possibly Kāpālika connection of Prambanan. We have only a few clues to go on, such as, for instance, the strict symmetry in evidence in the layout of the temple complex, which may well be interpreted in Tantric terms, considering that 'the notion of bipolar structure of the ultimate is one of the keystones of Tantric speculation' (Gupta, Hoens and Goudriaan 1979:53). Examples are provided by the reliefs of Siva and Pārvati, as well as of Sūrya and Candra on the lintels of the chamber of the Śiva temple, which may be taken to represent various binary oppositions such as those of east-west, high-low, malefemale, north-south, and sun-moon (see Jordaan and Edi Sedyawati 1990:20). Similarly, the reliefs on the candi apit, though as yet unidentified, yield at least two sets of oppositions: while the sides of the southern temple are covered with some twenty, more or less effaced reliefs of goddesses, the reliefs on the northern temple depict only several male figures, possibly also gods.

Other authors make a number of comments, usually casual, concerning Tantric traits at some Central Javanese temple reliefs. ${ }^{50}$ In regard to Loro Jonggrang these were especially made in connection with the Tanḍava dance scenes that are found there. According to Stutterheim (1924:153), the representation of the dance was 'typically Tantric' and comparable with the images of Dākin̄is in Buddhist iconography. What struck Bernet Kempers (Oudheidkundig Verslag 1948:25, see also section 9) was the 'bacchanal character' of the Tānd̦ava reliefs, although he did not use the word Tantric in this connection. ${ }^{51}$ Still, the fact that he pointed at similarities with the dance scenes at Candi Sewu

of the seat of government to East Java. Krom more or less suggested that the construction of the temple complex was not completed because of the move to the East, and that no one bothered to remove the unfinished Brahmā statue from the compound. This explanation is no longer tenable with an earlier, eighth to ninth-century dating.

50 One example is Bosch (1959) who points to a number of significant similarities in the representation of Yakșa figures on Borobudur and Pawang Lawas in Sumatra. In spite of these similarities, however, he maintains that both 'Sadāmada' ('always drunk') versions are incomparable because '[the] Buddhism of Borobudur was free from Tantric influences' (1959:239). That Padang Lawas shows a demoniacally enhanced version of the Yakșa figures is no reason, however, to consider the Buddhism of Borobudur free of such things. The find of skeletal remains at Candi Sojiwan proves that the Buddhism of Central Java was no less demoniacal and bloodthirsty than the later East Javanese and Sumatran expressions of it.

5t Clearly, drinking alcohol and indulging in sensual pleasures can be classed as pañcamakära, the rite of the Five M's followed by Tantric adepts (Moens 1924:530). In this connection, one could also mention the concluding scene of the Rāma epic on the Brahmā temple depicting six Brahmans at a ceremonial banquet consisting of fish, while the presence of such food would otherwise imply the commitment of a capital $\sin$ (see section 10. photo 6; Fontein forthcoming). 
(see section 10) indicates that he was not sufficiently conscious of the fact that only Tantrism provides the basis and context in which to understand these Hindu-Buddhist parallels..$^{52}$

In the absence of more concrete data on Hindu-Buddhist sects in ancient Central Java, it seems more reasonable to me to start by studying the architectural side, that is, by 'mapping' or surveying the temple complex through careful measurement of all the component parts and then determining if the data fit into a definite pattern. The identification of the system on the basis of available data from India can perhaps help us identify the sect that conceived the plan for the temple complex.

Unfortunately, conditions are rather unfavourable for this kind of research. In the first place this branch of architectural research does not seem to really appeal to the popular imagination, and thus draws but little attention. To a certain degree this confirms Bosch's observation that the iconographic rules of the Ágama and śilpaśästra received far more attention than the architectural precepts. For this reason, the work done by Dumarçay (1954, 1986b, 1994) deserves an honourable mention.

Yet, it would be incorrect to suggest that architectural research on Loro Jonggrang is less than advanced only because of a lack of interest on the part of archaeologists, This would be inconceivable considering the history of the reconstruction of the temple complex by the archaeological service. The present situation has rather to do with the loss of the measurements and the reconstruction plans during the Indonesian struggle for independence, when the regional office of the Oudheidkundige Dienst that was located in Prambanan became victim of the violence and was partially plundered. It is reported that the canvas containing the invaluable architectural drawings was used for clothing by some of the villagers who had lost everything in the turmoil (Oudheidkundig Verslag 1949:24). Bernet Kempers (1953:491) described this as an irreparable loss of scientific materials, the extent of which could not yet be assessed.

How frustrating the absence of reliable measurements must have been for Bernet Kempers' own research is evident from such sentences as,

'on the basis of data available to me, I now continually arrive at different conclusions, even about the proportions of the inside of the Siva temple. Although it is clear as a day that the [layout of the] complex must be based on a definite system, for the time

52 The same holds true for Krom's surprise at the fact that both Śaiva and Buddhist pilgrims from Champa came to Java in the early years of the tenth century, in order to be initiated in siddhiyätra, Tantric magical lore (Krom 1931:189). Bosch, however, has rightly pointed out that 'we shall have to keep in mind that Sivaite and Buddhist tantrism are closely connected and evolved contemporaneously along parallel lines, and have expressed themselves by making use of almost the same symbols and attributes' (1961:488). 
being I leave the question of which system this is unanswered.' (Bemet Kempers 1955:8.)

Today it is still not clear which system was followed, even though the contrary has been suggested in connection with the ritual deposits of Loro Jonggrang by relating these to the so-called vastupurusamandala system as described in Hindu architectural treatises (Soekmono 1974:330-4). On further consideration, this association seems to rest on nothing more than an informed guess, on the basis of the secondary literature without any reference to a specific architectural handbook.

Under the present circumstances, I think it would be advisable to follow Bernet Kempers' example and suspend judgement with regard to the architectural system, while at the same time not ignoring, but rather drawing attention to the matter of the apparently simple measurements. Accurate figures on these are badly needed, as the absence of reliable data has regularly given rise to all kinds of mutually contradictory statements by archaeologists, even about most elementary matters such as the measurements of the enclosing walls and the total number of subsidiary temples.

For instance, in regard to the measurements of the first enclosing wall, Krom, following Van Erp, only mentioned that its thickness was two metres and its total height 4.5 metres (that is, up to the second terrace, before the first tier of subsidiary temples), but said nothing about its length. The length of the second and third enclosing walls are respectively given as 200 and about 400 metres (Krom 1923a, I:446-50). According to Bernet Kempers (1955:9), the first inner wall was 100 metres long, the second enclosing wall 222 metres, and the third wall 390 metres. Dumarçay (1978:55) gives different measurements again, saying about the first wall that 'the square is not in fact exact, as the south side is $112 \mathrm{~m}$, but the north side $108 \mathrm{~m}$ long'. He states the length of the second wall to be 225 metres and does not mention the size of the third one at all. Remarkably, Dumarçay's presumably exact measurements of the first wall are not the same as the $110 \times 110$ metres given by the local branch of the Indonesian Archaeological Service (Anom 1991:60).

Similarly, regarding the subsidiary temples, we note a steady increase in the number reported. Uzerman's excavations initially uncovered the remains of three tiers of subsidiary temples, numbering 44, 52, and 60 temples, respectively. Later, the remains were found of yet another shrine near the eastern entrance, bringing the total up to 157. After Lulius van Goor (1919:13) and Krom (1923a:449) reported traces of similar buildings on the north-eastern side of the complex, the idea arose that there may have been a fourth, perhaps unfinished tier. This raised the total number to 224 . The Oudheidkundig Verslag of 1926 reported that the 
excavations had uncovered more remains of foundations, and suggested that, in addition to the four tiers of small temples, there may have been more, located within the salient parts (Dutch: voorsprongen) of the second wall, saying: 'How many there were cannot be indicated because the remains uncovered were too few. They should in any case be taken into account in calculations of the total number of structures in the temple area.' (Oudheidkundig Verslag 1926:8.)

It further reported that a road once led from Loro Jonggrang to the Śaiva ruins (that is, a few statues of Hindu deities) at Ratu Boko. This road was said to have been bordered by small temples. An exploration of the surrounding area as advocated by the restoration commission, however, was made too late: the local population had just begun removing the building stones of the shrines located along the road (Oudheidkundig Verslag 1926:8-9). Not everyone seems aware of these later finds, because several authors continue to mention the number 156 as the total number of subsidiary temples, comprising three tiers of subsidiary temples only (see, for instance, Holt 1967:54; Helfritz 1979:112).

Surveying and measuring should not be an end in themselves, however. As Loro Jonggrang has always been accorded a crucial position in the development of Hindu-Javanese art, any exact information on the architecture of the temple will ultimately be useful in resolving the question debated among archaeologists for so long as to the differences between Central and East Javanese art, and whether these are significant enough for us to speak of a discontinuous rather than a continuous development. To illustrate this point, I would mention the meticulous iconographic research conducted by Edi Sedyawati (1988, 1994), which, though largely confined to the statuary of Ganeśa during the late East Javanese Kadiri and Singasari periods, has yielded important additional information on Ganeśa statuary in Central Java, particularly at Loro Jonggrang. Sedyawati found out among other things that the statuary rules followed at Loro Jonggrang appeared to be in full accord with Hindu iconometric directives, and that this was not only the case with the statues of Ganeśa but also with Durgã and Agastya. With respect to specific iconometric data, she wrote, that the art of Loro Jonggrang (and of contemporary Candi Plaosan) was much more homogeneous than that elsewhere, and was not entirely comparable to that of other Central and East Javanese temples. This led Sedyawati to submit that:

This evidence supports the interpretation that Loro Jonggrang, as the principal temple of the kingdom at that time, was built during a period of close cultural relations between India and Java. [...] The interpretation of the different role of Loro Jonggrang in the development of Hindu religious art in comparison with other temples is hereby given further support:' (Edi Sedyawati 1994:79.)

As it is not quite clear what exactly is meant by the phrase 'different role of Loro Jonggrang', it may be useful to note that, in the controversy about the develop- 
ment of Hindu-Javanese temple architecture, one of the strongest arguments in favour of the alleged continuity of this architecture was provided by the early tenth-century dating of the complex, which gave Loro Jonggrang the function of a bridge between Central and East Javanese art in the wake of the transfer of the seat of government from Central to East Java. Stutterheim, it will be recalled, even tried to strengthen this idea by attributing various 'East Javanese stylistic elements' to Prambanan. Although the ambiguity of this notion has already been demonstrated, Edi Sedyawati's research offers further evidence in support of the idea of Loro Jonggrang's different, though not unique or incomparable, position. ${ }^{53}$ Partly in view of the new dating defended in the present book and the involvement of the Śailendras in its construction posited here, Loro Jonggrang can now be reinvestigated as a truly 'classical' Central Javanese temple, in which neither the Buddhist not the foreign influence should be ignored any longer. ${ }^{54}$ Indeed, Krom (1931:175) maintained, as far as the architect's fidelity to the Indian tradition was concerned, that the Śaivism of Loro Jonggrang is no more Indonesian than the Buddhism of Borobudur'.

\section{The statues}

Before discussing the statues of Candi Prambanan, two preliminary remarks should be made. Firstly, the decision to discuss the statues under a separate heading was made for editorial reasons which have to do with the manageability as well as the clarity of the arrangement of the material, and not for reasons of substance. The statues, as well as the reliefs that will be discussed in the next section, actually form an indissoluble part of the total design, and, just like the temple compound and the temples in which they were eventually installed, were conceived, designed, and made in accordance with the guidelines provided by the śilpaśasstra. In the discussion below I will illustrate this point with concrete examples.

53 As Edi Sedyawati notices herself, 'the Śaiva temples that face east are known to be generally found in Central Java, and were certainly built during the time when Central Java was still the centre of a powerful kingdom. The Saiva temples of East Java generally face west' (1994:170, note 27). Significantly, however, she did not observe that Loro Jonggrang's (and the contemporary Candi Sambisari's) near perfect orientation to the points of the compass is in accordance with that of Buddhist Śailendra temples which generally face east. 54 This formulation has been chosen on purpose, since the question of the Śailendra's foreign origin is still an enigma, in spite of all the arguments put forward in favour of an Indonesian origin by Stutterheim, Poerbatjaraka, and Boechari, among others. Not at all deterred by Wolters' (1979:10) misplaced enthusiasm about Boechari's solution to 'the Śailendra riddle', Sarkar (1985) again advanced the idea of the Śailendra's Indian origin. While one need not subscribe to all of Sarkar's conclusions, his idea has not yet received the crical attention that it deserves. 
Secondly, my discussion will take the form more of an inventory of problems than that of a real description. The existing descriptions of the statues in the principal temples are relatively complete and well known (see Krom, this volume). Rather than repeat what has already been said at length by others with more iconographic expertise, I will concentrate on pinpointing features that are less well described, as well as some still unsolved problems of interpretation.

Let me begin by tackling a difficult and virtually inexplicable problem that threatens to fall into oblivion due to the relative obscurity of the Dutch source material. This is the problem, pointed out by Jochim (1913), of whether the statues of Agastya, Ganeśa, and Durgā in the Śiva temple are actually standing in their original places. Jochim referred here to Brumund (1853), who believed that the statues had been brought here from elsewhere and were only later placed in their present positions. One thing pointing in this direction, according to Brumund, was the fact that the statues and the slabs with their nimbuses against which they were placed did not belong together, as the latter were too simple and, more importantly, too small. Jochim mentions that IJzerman held a different view and claimed that

'a careful examination has led me to conclude that the existing nimbuses certainly do belong with the statues placed in front of them [and] that these are a perfect fit for the statues, so that there cannot be any question of their having been moved' (IJzerman 1891:49-50).

Jochim was quick to point out that he was not at all in agreement with this idea. His explanation for this deserves to be cited at length. He wrote:

The nimbuses, which are made out of small stones mounted against the back wall, are edged with a border of flames within which there are three more plain bands. These, just as on the statues of [Candi] Plasoan, end at the bottom as protrusions, which here have been given makara-like forms and decorations. IJzerman's statement to the contrary notwithstanding, the image of Durgã, and to an even greater extent that of Guru [Agastya], both cover part of the ornamentation (the border of flames, the bands, and the protrusions) because they are standing right up against it, which surely can never have been intended. This is not the case with the Ganeśa statue, whose nimbus is much wider; here the entire ornamentation is visible. It seems strange, furthermore, that there is another nimbus behind the back slab, which is completely covered by the statue. If the nimbus carved in the back slab was inadequate for these statues, and in addition required a large, flaming nimbus, why don't the higher gods, Śiva, Brahmā, [and] Vișnu, have one of these?'

Jochim continues:

'Like Brumund, I have the impression that the present nimbuses were originally intended for other gods, or at least for deities of another form and in any case lacking a back slab. Brumund wonders who these gods were. The shape of the nimbus reminds onc, because of [the] similarity with those in nearby temples, of Buddhas and 
bodhisattvas, though that would be absurd. I would assume rather that the architect and the sculptor worked independently of each other; with the former providing for the same number of deities as there are now, though of another shape and without back slab. Knowing that Ganeśa would be about so much wider than Durgā or Guru, he would have made the appropriate nimbus equally larger in anticipation. The sculptor, however, knew nothing about those nimbuses into which the statues had to fit, and so made these with a back slab, just like the others.' (Jochim 1913:380-1.)

This hypothesis was later to be partially supported by Krom. ${ }^{55}$ Where he felt that Ganeśa's statue and throne belonged together, this was 'certainly not the case' with the statues in the other chambers, namely those of Agastya and Durgã. Krom also concluded 'that these thrones were originally intended for smaller statues, or that the sculptor and the architect, as a result of some misunderstanding, bore each other's work insufficiently in mind' (Krom 1923a:474).

We will have to study this problem very carefully. First, we must remember that during the greater part of the 19th century most scholars were uncertain as to whether Prambanan was a Hindu or a Buddhist monument. On the account of both the presence of many Buddhist temples in the vicinity and the demonstrable stylistic similarities, many scholars were inclined to regard Prambanan as a Buddhist sanctuary, notwithstanding the presence of the statues of Durgā and Gañeśa in the northern and western chambers of the Śiva temple (Mackenzie 1814:49; Baker, as cited in Raffles 1817, II:10). Brumund was one of these scholars, and it is not improbable that, considering the imperfections in the way precisely these statues were fitted, he came to the conclusion that they had been moved. His theory was adopted by Leemans, who even went so far as to predict that the main chamber, which at that time had not yet been excavated, might be found to contain a statue or a relic of the Buddha (Leemans 1855:23). This theory would be refuted by IJzerman's excavations. The latter wrote: In view of the discovery of the large statue of Mahãdeva in the place of honour, the Śaiva character of the temple group is evident' (IJzerman 1891:43).

Jochim, like a truly independent scholar, checked the data regarding the fit between the statues and their nimbuses and thus presumed to cast doubt on Uzerman's theory. Krom agreed there was a problem here, but neither his nor Jochim's solution are convincing to me. Assumptions about 'some misunderstanding', or sculptors and architects bearing 'each other's work insufficiently in mind,' or even 'not knowing anything about each other's work,' are to my mind explanations prompted by a misconception of the work of sculptors and

5s IJzerman (1891:42) also refers to Friederich, who believed that the dvärapäla in the antechamber of the main cella of the Siva temple bore traces of having been removed to this place at a later date, analogous to the situation [elsewhere]'. Because Jochim and Krom did not say anything about this matter 1 assume that they did not share Friederich's opinion. 
architects, certainly where religious architecture is concerned.

For the carving of the statues (or the reliefs, for that matter), the proportions must have been determined beforehand, while the general design must have been roughly indicated by chalk marks or scratches on the stone that was to be used. In this, most probably drawings served as examples, the correctness of which was established by reference to the Puranic literature and the silpaśâstra. In view of the above-mentioned intended ritual effectiveness of these statues, it seems to me impossible that the 'priest-architect' should have allowed the sculptor a free hand in carving it. Any misunderstanding here must be on the part of the archaeologist, not on that of the makers, as the above authors would have us believe. However difficult this may be to believe, we cannot but conclude, I feel, that the existing statues are not the original ones and were placed in their present positions at a later date.

Because of the fundamental nature of these matters, a change in the composition of the pantheon would have been a very extraordinary occurrence, and I know of only a few instances of this happening in ancient Java. We have one such example from Central Java concerning a change in the composition of the Buddhist pantheon in Candi Sewu. In the absence of more concrete evidence with regard to Loro Jonggrang, I can only demonstrate the plausibility of my hypothesis on the basis of this one example. This is appropriate because the technical and symbolic problems involved here are comparable, though not wholly identical with those that must have been posed by Loro Jonggrang. Furthermore, because of the proximity of the two temple complexes to each other, both physical and temporal, and also in view of the indications in the Kelurak inscription of the ideological relationship between them, the possibility that the changes at Candi Sewu and those at Loro Jonggrang are connected with each other cannot be precluded.

As was pointed out earlier (see section 6), the Kelurak inscription concerned the consecration of a statue of the bodhisattva Mañjuśri. According to Bosch, there was more to it than that, however, and Kelurak may also have served as the blueprint for a grand programme of construction whereby the Trimūrti were to be accommodated at Loro Jonggrang on the one hand, and the Triratna were to bring about a composite mandala in Candi Lumbung and Candi Sewu, on the other. According to this scheme, Candi Lumbung would have had to be dedicated to the Triratna itself, and Candi Sewu to the gods of the Vajradhätu.

Shortly after the publication of the Kelurak inscription, Bosch (i961:111-33) went further into the possible composition and spatial arrangement of the Vajradhātu pantheon at Candi Sewu, on the basis of supplementary information from Balinese and Japanese Buddhist texts. He demonstrated that the theory of the Buddha Vairocana having been placed in the main chamber of the principal 
temple not only was based on extrapolations from the Balinese and Japanese texts consulted by him, but also was supported by the then recent discovery of a fragment of the head of a Buddha figure that had the characteristic curls of Vairocana. Going by the dimensions of this fragment, Bosch assumed that it originated from an enormous statue, which he estimated to have been about 12 feet high. An image of these dimensions could only have been accommodated in Candi Sewu, and then only as the principal statue of that sanctuary.

Recent Indonesian research has shown that in the main Bosch's conclusions are still valid, but that the composition of the Vajradhātu pantheon at Candi Sewu was not the original one and must in any case have been of a later date than the Kelurak inscription, in which Mañjuśrī was still the focus of attention. That Mañjuśñ was once placed in a more central position is evident from, among other things, a dated stone inscription discovered in the temple area in 1960 , which speaks of the completion in the Śaka year 714 (792 AD) of the work of extension and improving a temple which is referred to as Mañjuśrigrtha, the 'House of Mañjuśri'. The Indonesian archaeologist Kusen, basing himself on Bhattacharyya's (1958) work on Indian Buddhist iconography, suggested that the original mandala of Candi Sewu could have been the so-called Dharmadhätuvagisvaramand̦ala, in which Mañjughoșa (another name for Mañjuśrī) is the principal figure (see Anom 1992:57). In this mandala a place is also assigned to gods from the Hindu pantheon like Brahmā, Vișnu, and Maheśvara, exactly as the Kelurak inscription mentioned. A distinctive feature of these adoptive Hindu gods is the particular position of their hands, or añjalimudrā. As luck would have it, a small silver figure of Śiva (Maheśvara) seated on a bronze yoni was found in 1991 in the second inner compound of the Candi Sewu complex, which displayed this añjalimudrā hand position. ${ }^{56}$ This pose is described by iconographers as one whereby 'both hands [are] clasped together, palms touching, and held near the chest in salutation' (Liebert 1976:16; Bhattacharyya 1958:363).

Kusen supposed that the construction of Candi Sewu passed through a number of stages. Stage one, beginning with the Kelurak inscription, only involved as the text itself mentions, the consecration of the Mañjuśri statue. Stage two was reached ten years later, with the completion of the extension of the temple, the 'House of Mañjuśri'. Then, at an unspecified time, which for

56 Lest the discovery of this figure of Siva be considered coincidental, I wish to draw attention to the recent find of a small bronze figure of a bodhisattva (representing Vajrapānij) among the ruins of Candi Sambisari, a Śaiva temple to the west of Prambanan and contemporary with Loro Jonggrang, Plaosan, and Sojiwan (Mengenal Candi Sambisari n.d.:6, 23). 
convenience sake is called stage three, Mañjuśri must have been removed from his throne and replaced by Vairocana.

Concrete evidence of this change was discovered by Dumarçay, whose architectural research showed that the throne in the main chamber of the principal temple at Candi Sewu had at some point been changed to make room for a larger statue (Dumarçay 1986c:29-30). This larger image could have been a new statue of Mañjuśri, but is more likely to have been one of Vairocana. While in the first case the change would be inexplicable, in the second case there are symbolic considerations which could explain the enlargement of the throne and the statue, namely the fact that Vairocana is a Buddha, a much higher being than Mañjuśñ, who is a bodhisattva.

The replacement of Mañjuśñ by Vairocana seems to have necessitated other architectural and stylistic changes. From Dumarçay's and Kusen's architectural descriptions it can be inferred that the shape of the niches in the entrance hall of the principal temple were at one stage adapted to accommodate seated gods in place of the earlier standing ones. These, and other changes that will not be discussed here, are very significant and provide strong evidence in support of Kusen's hypothesis about the replacement of the Dharmadhãtuvagisvaramandala with the Vajradhätumandala as described by Bosch.5?

What happened to the Mañjusri statue cannot be discovered. It is not ruled out that a new, probably stone, statue was erected in a place further removed from the sacred centre, perhaps in the subsidiary temple (now known as candi perwara No. 200) in front of which the Mañjuśrigrha stone inscription was discovered. Kusen suspects that the stone inscription was transferred to this outer temple because its contents, and thus also its position in the centre, were no longer in agreement with the newly introduced mandala.

As far as Loro Jonggrang is concerned, we lack such neat clues. A satisfactory answer to the question of which statues stood there first, and why they were replaced, cannot be given. Unlike Jochim, however, I do want to confront the 'absurdity' or anomaly of the resemblance of the shape of the nimbus to that of a statue of a Buddha or bodhisattva. Because the date of the foundation of the temple complex has now been pushed back, and in light of the possible involvement of the Śailendras in its design, this idea does not seem as incrongruent as it once did. Two possible explanations may be suggested.

57. Being unacquainted with the change of mandala as a result of the replacement of Mañjusn by Vairocana, Boseh did not quite know what to do with the prominent position of Mañjustin in the collection of small bronzes in the well-known Nganjuk find. Noting that the Nganjuk mandala is not identical with the Vajradhãtu one, he turned the developmental sequence around, positing that 'it [the position of Mañjuśri] will have to be understood as a sectarian subsidiary form or a transformation of it' (Bosch 1961:122, note 22). 
The first takes the text of the Kelurak inscription, in which Loro Jonggrang is dedicated to the Trimurti but is simultaneously adopted into a greater Buddhist entity that also encompasses Candi Sewu, as point of departure. In this light it is not unconceivable that the change to another mandala at Candi Sewu also had consequences for the composition and spatial arrangement of the Loro Jonggrang pantheon. Just as at Candi Sewu, this pantheon did not necessarily have to consist exclusively of Hindu gods, so that the deviant nimbuses may indeed have originally belonged to some unknown bodhisattva. When later all kinds of drastic architectural and stylistic adjustments had to be made, as a result of the replacement of Mañjuśri by Vairocana at the Candi Sewu complex, these could have extended as far as Loro Jonggrang, where in the process Agastya and Durgã took the place of the hypothetical bodhisattva.

It is important to note that the use of bronze for one or more principal statues in Candi Sewu and stone in Loro Jonggrang points at a difference in status between the mutually related Buddhist and Hindu pantheons. This would confirm Pott's thesis that the triad Sewu-Bubrah-Lumbung formed the 'superstructure', and Loro Jonggrang, with the temples for Śiva, Brahmã and Vișnu, the 'substructure' of a Buddhist Mantra system (Pott 1966:120). Such a difference in status is also indicated by the añjali hand position of the silver Śiva figure that was found at Candi Sewu. The anjjalimudrä is the position of respectful salutation and adoration, in this case for the Buddha Vairocana who was located in the centre of the Sewu complex.

It may further be noted in passing that the hypothetical development that is implied by this first explanation is not without irony. While originally the use of bronze and stone for the statues may have served to indicate the status of each of the two complexes relative to each other, it is precisely because of the use of metal in Candi Sewu that its temples were plundered first, while most of the principal stone statues at Loro Jonggrang were evidently not interesting enough to the plunderers and thus were preserved for posterity.

The other explanation is that there was a connection between the replacement of some of the statues and religio-political developments following the expulsion of the Śailendras. However much I am opposed to the idea that Prambanan was intended as a rival to Borobudur, there is some evidence of a religious conflict at the end of the Central Javanese period, with the new rulers, stimulating Hindu orthodoxy for as yet unexplained reasons (De Casparis 1956:292, 318 note 20). It is interesting to note that this Śaiva renewal was presented in terms of a national liberation. ${ }^{58}$ Aichele's searching analysis of the Old

5* The fact that the dynastic conflict took a nationalistic turn, incidentally, may well be taken as an indication of the Sailendra's foreign origin. 
Javanese Rāmāyana has shown, moreover, that the author of this literary masterpiece was making fun of the Buddhists through the use of subtle metaphors and urging his audience not to be misled by them (Aichele 1969:137-9). Hence Poerbatjaraka's labelling of this literary work as 'fanatically Śaiva' (Poerbatjaraka 1932:169). In an earlier publication I pointed out that in this political climate of intolerance it must have been quite easy to disguise Prambanan's Buddhist background and cause it to be completely forgotten within a short time. The replacement of the statues may very well have been taken place in the context of such an ideological cleansing drive orchestrated by those in power. ${ }^{59}$

Which of these two explanations is the correct one will have to be determined by further research, though this will be far from easy. First of all, it will need to be ascertained how the replacement was carried out technically. While searching for a possible clue in the existing archaeological literature, I was struck by how little is known about the technical aspects of the construction of Hindu-Javanese sanctuaries in general and about the carving of statues and reliefs in particular, especially in comparison with the information that is available about ancient Greek, Egyptian and South American monuments.

The little that is known on the subject was written by Van Erp (1909:170-1), whose data were partially borrowed by Krom (1923a, I:147-64). ${ }^{60}$ Both these authors report the use of boulders for the foundations in the temple area; of sandstone or marl as a filler for hollow walls; and of trachyte or andesite for the exteriors of the walls of the temples, the enclosing walls, and the statues. The sandstone or marl probably came from quarries in the Ratu Boko area. The idea that the stone was obtained there provided the occasion for the verbal fencing between Krom and Stutterheim, about whether the Śailendra ruler would have been able to stand the noise of all the cutting and sawing so near his kraton. What they did not discuss, however, was how the workers moved the blocks of sandstone or the andesite boulders out of which the statues were carved, some of which weighed some hundreds of kilograms, to the building site. This must have been done by means of all kinds of pulling and lifting devices worked by

51. Just as in the case of the phenomenon of syncretism, it is inappropriate to draw artificial parallels with the religious attitudes and seeming tolerance of the Javanese today. It is naive, to my mind, to rule out the possibility of the occurrence of certain forms of iconoclastic acts in the period under study.

6) Krom (1923a, 1:447-8) cites an unpublished report by Van Erp entitled 'Verslag betreffende de herstelling der neven-cella's van den Hoofdtempel van Prambanan' as a very important treatise on Central Javanese art. Regrettably, I have not succeeded in tracing this report. According to his great-grandson, Van Erp's research materials and several manuscripts were destroyed during the Second World War when allied planes bombed his house in a misguided raid on The Hague in March 1945 (personal communication A.Th. van Erp). 
humans. But information about this is lacking. Then on arrival at their destination, the stones must have been hewn, chiselled, and rubbed smooth. Again, hardly anything is written about the tools used for this, about the techniques employed, or about how the large blocks of andesite and the finished statues were subsequently installed in their appropriate places. ${ }^{61}$

The reason for my drawing attention to such matters as the quarrying and carving of stone is, as I pointed out before, that the statues of gods at Loro Jonggrang were made of stone, unlike those of Candi Sewu. The replacement of the principal statue and the figures of the attendant deities in the antechamber of the main temple of Candi Sewu involved statues made of metal statues, namely bronze, silver or gilded bronze. Naturally there is a difference in the inherent possibilities of these materials and the technical aspects of working them. Take, for instance, the difference between the replacement of the original statues at Loro Jonggrang with stone images of more or less the same size, and the substitution of a larger statue for the principal one at Candi Sewu. If at Loro Jonggrang the size of the temple chambers and their entrances may have had a restricting influence, at Candi Sewu this was obviously not the case. Here even more than in the case of the Mañjuśri statue, the existing dimensions of the temple chamber and entrance had to be taken into consideration when installing the Vairocana statue. ${ }^{62}$ Although the brass image of Vairocana, just like the one of Mañjuśri, because of its large size, was made up of various separate parts, the new statue had to be assembled in the confined space of the chamber. Where there was overlapping at the seams, rivets were used, which, where necessary, were welded together or soldered. Proof of this is provided by the brass fragments and charcoal remains found under the stones at the rear of the throne on which the statue was placed. These are the stones on which the larger statue of Vairocana once stood and thus they date from the time it was placed here.

61 Allegedly, volcanic rock, also known as trachyte or andesite, is fairly easy to work with copper or bronze tools. According to a Dutch sculptor of my acquaintance, Lucas van Blaaderen, it should be possible to make a replica of the famous statue of Prajñāpāramitra in about two months. This was confirmed by Peter Buurman, the owner of such a replica.

62 My account of the installing of the statues differs somewhat from that given by Kusen (see Anom 1992:69), who gives the impression that the image of Mañjuśri was moulded in one piece rather than being made up of different parts. However, large bronze statues like this cannot usually be made other than out of a number of different pieces. Kusen furthermore associates charcoal remains that were found with blacksmithing (peleburan) and metal-casting (penuangan logam), though this is improbable. This kind of activities in the enclosed area of the temple chamber would have been too dangerous and impractical, even leaving the restrictions on the movements of the workers out of consideration. The heat produced would easily have been apt to cause damage to the statue in the form of bubbles. It is much more likely that charcoal was used for minor soldering and welding jobs. I wish to thank Lucas van Blaaderen for this suggestion. 
Aside from these technical aspects, there are also the symbolic implications that make the replacement of the statues so difficult to imagine. Whatever may have been the precise reason for this, even a limited change of position of one or a few principal statues would have had repercussions for the arrangement of the other images of deities within the larger system, or for the ritual groundplan (mandala) that was followed at Prambanan, in which, as was said above, gods from nearby Buddhist sanctuaries could originally have been included as well. This is a caution to iconographers to remain alert for any other traces of sculptural adaptations and not simply to dismiss these as errors and oversights.

A piece of information that seems vital for the reconstruction of Prambanan's ritual ground-plan is provided by the identity of the statue on top of the huge Kāla head on the eastern side of the Śiva temple (see Photo 26 of Kāla head). First mentioned by Bernet Kempers in his article on the completion of the reconstruction work on the Siva temple, this statue never attracted the attention that it deserves. Bernet Kempers (1955:30) described it as simply a 'deity placed against a background of clouds'. However, it must be either a high-ranking or an extraordinairy deity, considering its elavated position on top of the Kāla head, which is even higher than that of the image of Śiva carved in relief on the panel above the lintel over the doorway of the main chamber, which contains the statue of Śiva Mahādeva. Reconsidering an earlier attempt at identification, I identified this deity as Śiva Mahāyogin (Jordaan and Edi Sedyawati 1990:1821), although this identification was tentative and still needs corroboration by concrete evidence. ${ }^{63}$

Another unsolved problem is that of whether there used to be any statues in the two candi apit, the shrines located on the northern and southern sides of the two rows of three temples respectively, and if so which. Reiterating Bernet Kempers' remark (1955:18) that the purpose of these shrines is unclear, I wish to remind the reader of IJzerman's observation (1885:271) that, though the southern temple was found to be completely empty and the northern was almost totally destroyed, 'there [that is to say, near the remains of the northern "court temple"] one can still see the statue of Durgā, which Brumund wrongly described as a seated Buddha with six arms'. Bernet Kempers repeated this statement in a later publication, citing the short description of the statue given by Brumund, which ran:

63 My photographs of this two-armed deity, though taken with a telephoto lens, were too indistinct for me to make out its attributes (see Photo 26). As in order to be able to get near this statue one needs to erect a scaffold, I was obliged to leave the identification of this statue till later. 
'Both the middle hands are folded in front of the chest; of the two lowest ones, the right one is lying on the knee with the palm up, and the left one is holding a padma. Of the two upper ones, the right one is holding up a ring (rosary), [while] the left one is holding a little axe, like [that which is] often associated with Ganesa. On the back slab a nimbus has been chiselled, while a small crown has been placed on the head. The statue is less than two feet in height, and is placed on the floor of what used to be the chamber of the small northern temple.' (Uzerman 1891:58.)

Uzerman continues with an intrinsically interesting comparison of the alleged statue of Durgā with relief depictions of Buddhist goddesses on Borubudur and Mendut. I am more concerned to find out the whereabouts of this statue, however, which seems to have disappeared more or less unnoticed. Krom (1923a, I:452) writes that 'there is no evidence of the occupants of the smallest structures on the northern and southern side of the square'.

This small statue is not the only one to have disappeared. The statues of Vișnu's avatäras, which were reported by Krom (1923a, I:482) to have been returned from the museum in former Batavia to the original site, seem to have vanished during the Indonesian struggle for independence (Soenarto 1991: $41) .{ }^{64}$ No trace was ever found of the statues from the 224 candi perwara, either. If we are to believe the above-cited text of the Old Javanese Rāmāyana, all these temples accommodated gold figures of deities and demons fighting for possession of amrta, the elixir of life. Just like the figures occupying the many niches in the principal temples, these were probably bronze statues that were stolen and melted down for other purposes in later times. Unless a miracle happens and the manuscript of the silpaśāstra that served as a guide to the Prambanan mandala is found, we will never know who all the gods and goddesses portrayed here were.

\section{The reliefs}

The reliefs of Candi Prambanan may be divided into two broad categories: narrative reliefs, which include the Rāmāyana reliefs on the Śiva and Brahmā temple and the Kṛșna reliefs on the Vișnu temple, and what I will term 'iconic' reliefs depicting individual deities along with their attendants, such as the reliefs of the guardians of the sky (aștadikpäla), carved on the outer wall of the Siva temple.

These categories are descriptive rather than absolute, because if one is to fully understand the meaning of the iconic reliefs, they must also be considered in their mutual relationships, as is obvious in the case of the guardians of the

it The Varāhavișnu, the boar incarnation of Vișnu, is still preserved in a fragmentary condition in the National Museum, Jakarta (Paul 1978:316). 
sky. The same is true of the reliefs of dancing figures on the outer face of the balustrade of the Śiva temple, which originally depicted the consecutive movements of a particular Indian dance, the Tândava. Although these are not narrative reliefs in the sense that they depict a complete story, the dance whose movements they portray is assumed to relate to specific meaningful themes, such as fertility, creation, and destruction (Stutley 1977:297).

The fact that the iconic reliefs thus also have a meaningful rather than purely a decorative function implies that what they depict as well as their positioning must have been decided in advance. Hence, just as in the case of the puzzling deviations in some of the statues that were discussed in the previous section, we are not to have recourse to explanations in terms of misunderstandings between architects and sculptors or idiosyncratic Javanese adaptations of the sacred texts to solve the difficulties we might encounter.

Stutterheim (1925) was one of the first scholars to realize the shortcomings of this approach. The credit for showing that the sculptors of the Rãma reliefs at Prambanan were not following Vālmīki's classic work but another text which must in some respects have been very similar to the Hikayat Serri Rama (HSR), a much later Malay version of the tale, must go to him. ${ }^{65}$ Rather than interpreting this deviation as an adaptation of the classic tale to local circumstances. Stutterheim felt that the differences must be traceable to folk-traditions that had existed side by side with the official version of the epic since ancient times, already in India, where the tale originated. Elements of these folk-traditions were found not only in hikayat, lakon, and other indigenous literary works, but also found their way into the Rāma reliefs on the Śiva and Brahmā temples at Prambanan.

Stutterheim's pioneering study of the Rāmāyana reliefs at Prambanan is well enough known and does not need a lengthy introduction. There is one important issue which, as I see it, was not done full justice in his work, however. This is the question of how the reliefs were actually conceived and produced. When talking of folk-tradition, one thinks primarily of an oral tradition, which is apt to give rise to the impression that the reliefs may have been freely chosen and that their execution was for the greater part left to the artist's own discretion. ${ }^{66}$ This was the position taken by Vogel (1921:215), in fact, who had

15 A. Zieseniss (1963:187) assumes the HSR to be a post-epic work which 'was carried by word of mouth to Indonesia between the 13th and the 17th centuries'.

6.6. The oral history background can easily be taken as a source of error to explain the divergencies between the reliefs and the canonized texts. Take, for instance, Gonda's remarks about the carving of the Karmavibhanga on Borobudur: 'deviations from the text [...] may be explained from the supposition that the sculptors who in all probability were unable to read the Sanskrit text, and who may have received oral instructions did not suc- 
wondered a few years previously if the sculptor at Prambanan had closely followed a written text at all, as the sculptor at Borobudur clearly had. In depicting the Buddha legend here, he followed the text of the Lalitavistara, among others. In the case of such a popular story as the Rãmãyana, the supposition seemed most plausible to Vogel that the sculptor had recourse to an oral tradition current among Indians and the Javanese. Stutterheim also cited Van Stein Callenfels (1922:47) in this connection, who had written that he wished to leave undecided the question of whether in Java such an oral tradition may not have been committed to writing in some form or other and whether it was this text which the sculptor had followed:

The question should no longer be left undecided. In my opinion the architects and sculptors at Prambanan definitely worked from a written text which has since been lost. I have two reasons for supposing this. Firstly, one cannot ignore the inherent constraints of temple architecture which, certainly in the so-called Central Javanese 'classical' period, had by no means weakened regardless of whether the temple concerned was a Buddhist or a Hindu one. ${ }^{67}$ The greater popularity of the Rāma epic notwithstanding, I do not believe that the Răma reliefs at Prambanan were conceived and executed in any different way from the Buddha reliefs of Borobudur.

My second reason for assuming the existence of a textual guide is that it would otherwise be impossible to explain how the neat arrangement of the story over the available wall space would have been arrived at. The neatness of this arrangement is evident from, among other things, the correspondence between Rãma's life-story and the course of the sun that was Jater discovered by Stutterheim (1928) to be reflected in it (Stutterheim, this volume). Regardless of whether the correspondence is really consistently reflected in it, there can be no doubt in my opinion that there is a design here that was carried through in accordance with strict architectural rules.

For useful data on the design and execution of reliefs, Fontein's (1989) work on the Karmavibhanga reliefs of the so-called hidden foot of Borobudur should be consulted. On the basis of a detailed analysis by reference to a number of different versions of the same story, he drew some conclusions about the carving of the reliefs concerned that are probably relevant for the Rämāyana reliefs at Prambanan as well. Fontein concludes that:

ceed in reproducing its contents exactly. Now a detail contained in the text is omitted, then again a particular figure or event does not tally with the printed work.' (Gonda 1970:226.)

67. Much earlier, Gonda, in similar vein, has argued: 'As there is little room for the hypothesis that it has been the architect or the sculptors who invented a version of their own, the chances are that they used a text, lost to us, which, whilst omitting what is superfluous, set out the subject-matter in a shorter and more satisfactory way' (Gonda 1970:228). 
The Karmavibhariga reliefs provide proof, time and again, that this process [by which the subject matter treated in the texts was distributed over the available wall space] was one on which great attention was lavished. [...] Skipping, glossing over, or ignoring passages of the text represents the opposite extreme and for that there is [...] no solid evidence.' (Fontein 1989:75.)

Fontein's remarks about the design of the reliefs show that this probably did not differ from the way things were done at Loro Jonggrang either:

'First the architects or the learned monks in charge of the project must have made a pradaksinā with the holy text in hand, deciding on the subject matter of each relief or section thereof. After the captions or key words had been carved in the upper margin, the sculptors went to work. They probably first made a preliminary drawing on the stone itself and then started to carve the outlines and to shape the silhouettes of the figures. Only after the outlines had been deeply carved they began to give shape and volume to the figures themselves.'(Fontein 1989:74-5.)

That Fontein is also convinced that the sculptors worked according to a detailed plan and had little if any personal freedom is evident from, among others, such phrases as 'monks instructing the sculptors', 'ecclesiastical supervisor', and even 'ecclesiastical planning committee'.

Though this reference to the planning and execution of the reliefs at Borobudur may be enlightening, it does not exonerate us from the responsibility of providing evidence for the systematism in the design of the reliefs at Prambanan. For this purpose I would cite Krom, who drew attention, a few years before Stutterheim posited the correspondence between the life-history of Rama and the course of the sun, to the fact that the Rảma story on the Śiva temple ends at the point of the crossing to Lankā. Krom writes:

'It is evident that this abrupt ending of the story, just before reaching its climax, presupposes its continuation elsewhere. Thus the breaking-off of the story on one building, in order to be continued on another, provides more evidence for the close relationship between all these temples, which owe their existence to a single general design.' (Krom 1923a, L:463.)

In connection with Krom's remarks about the singular breaking-off of the Rāmāyana series on the main temple and its continuation on the balustrade of the Brahmā temple, Fontein points to the theatrical effects of this on initiates. He writes:

'By breaking off the story just as the army of the monkeys is crossing the causeway to Lankă, the sculptors made the viewers cross over from one temple to the other, as if they were following in the monkey's footsteps' (Fontein, forthcoming).

I would add to this that this stratagem was so effective precisely because the design of the temple area as an artificial water reservoir may actually have separated the temples from each other by water. It cannot be accidental that not only 
the closing scene of the Rāma story on the Siva temple, but the opening scene is connected with water, the latter even with holy water, because it depicts Vișnu reclining on the snake Śeșa, floating on the Ocean of Milk. ${ }^{68}$ These and other phenomena to be discussed below are irrefutable evidence of the well-considered arrangement of the reliefs within the overall architectural design.

Granted that the reliefs at Prambanan were placed on the temple walls in accordance with a definite plan on the basis of an as yet unknown text, it would be going too far to claim that there is absolutely no trace of any Javanese influences in the reliefs. Such influences are certainly in evidence, else it would be illogical to speak of 'Hindu-Javanese' art instead of 'Indian' or 'Indian colonial' art. That the Javanese sculptors were unable to negate their own artistic inspiration in carving the decorative motifs, and might even consciously have allowed it to come into play seems undeniable to me. Yet, one must beware of taking the apparent Javanese character of some of the representations as proof of a Javanese adaptation of the text without further ado. As I see it, one only has proof here of an early division of labour, whereby the execution of the plans and also the heavier labour were delegated to the indigenous population. With Bosch (1920:142), I believe that the overall architectural design of Prambanan, possibly comprising both Sewu and Loro Jonggrang, was conceived in Indian monasteries. Whether actual Indian monks and guru were closely involved in the execution of the building project (as was indicated in the Kelurak inscription, and as had earlier been the case in the construction of the Kalasan temple), or whether returned Javanese pilgrims acted as guru, but following the silpasaâstra, cannot at this stage be definitively determined.

What activities were delegated and how rigorous this division of labour was is not known, and can hardly be established now. Even where decorative motifs are concerned, in which one may justifiably suspect a not inconsiderable Javanese influence, there are hardly any indications as to how, that is to say on the basis of what specific criteria, the Javanese character can be determined. All that has been said on this subject in my opinion testifies to a considerable degree of selectivity or subjectivity.

As an example, let me take the episode of the wrapping up of Hanuman's tail, in which Bosch (1954:17) saw evidence of Javanization. What Bosch probably had in mind is the episode in which Rāma's envoy, Hanumăn, is not offered a seat during his audience with Rāvana and solves the problem created by this lack of courtesy by rolling up his tail beneath himself so that he comes to sit on

6x I am indebted to Dr 1. Kuntara, who pointed this out to me in an informal discussion of the central courtyard in light of his recent article on the 'sea' in Old Javanese literature (Kuntara Wiryamartana 1992). 
an equal level with Rāvana. According to Fontein (forthcoming) this episode is known not only in Java but also in Thailand and Malaysia, where it is still popular (as is evident from the HSR). Quoting from Brockington's study (1985) on the evolution of the epic, he adds '[where] it may have been transmitted through Bengal'.

To remove any impression of selectivity, one would do well to pay more attention to reliefs that betray precisely non-Javanese influences, both by the arrangement of the reliefs and unusual body postures and attributes of the figures depicted on them. With respect to the arrangement of the Loro Jonggrang reliefs, it was Groneman (1893:6) who noticed that it was quite similar to the one found on Borobudur and other Buddhist temples, and the first to put forward the idea that the arrangement could be related to the course of the sun. ${ }^{69} \mathrm{He}$ further observed that this relation was only valid for the northern hemisphere, where, he said, the Buddhists hailed from (1893:6, note 1). Body language offers yet other clues for possible non-Javanese influences. Groneman noted with reference to the pointing with the right index finger by the demon Tãraka, that the Javanese do not point with the index finger, but with the thumb. The recurrent use of the index finger proves that no Javanese worked on these statues' (1893:11, note 11; see also Stutterheim 1925:146, 150; Fontein 1989:84). Similarly, Stutterheim (1925:153-4) remarked with reference to the representation of a dancing woman not only that the dance was typically Tantric, as we see it performed in the Buddhist representations of figures of Ḍākinīs and other "horrifying" creatures', but also that the orchestra has a decidedly 'non-Indonesian character' (see Photo 5).

These examples show that the Javanese character of certain representations is not directly evident, and needs more careful consideration than it has been given up to now. How much remains to be done is clear from Fontein's claim that:

'the study of postures and gestures in the art of Central Java is only in its infancy, and that much work remains to be done, by studying the reliefs as well as the Javanese dance, before the full range of the vocabulary of non-verbal communication can be reconstructed' (Fontein 1989:101).

69 This idea would be elaborated by Stutterheim (1928, this volume) who did not, however, refer to Groneman nor mention the fact that the correspondence did not quite fit in Java. Noteworthy is the contrast here with Angkor Vat in Cambodia where the measurements of the temple and the arrangement of the reliefs do relate to practical astronomical and calendrical concerns (see Stencel, Gifford and Moron 1976). 


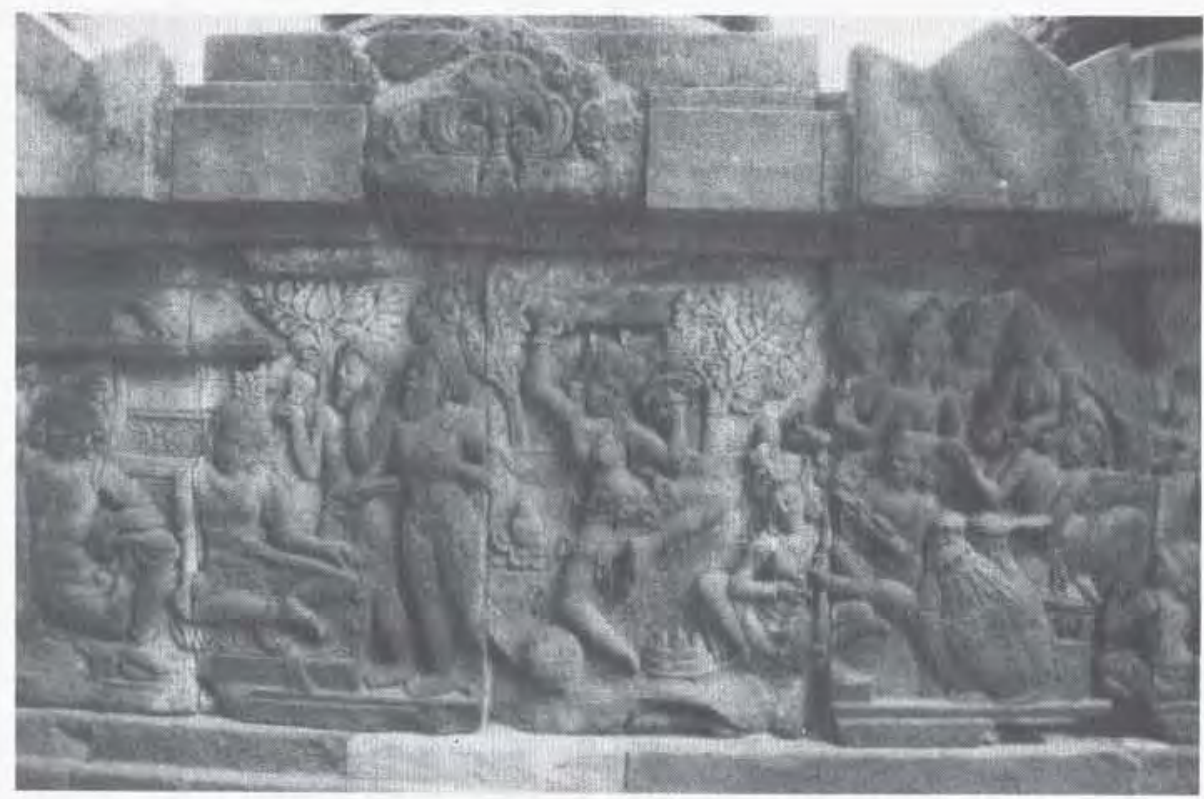

Photo 5. Relief of dancing woman with orchestra (photograph by Piet Holthuis)

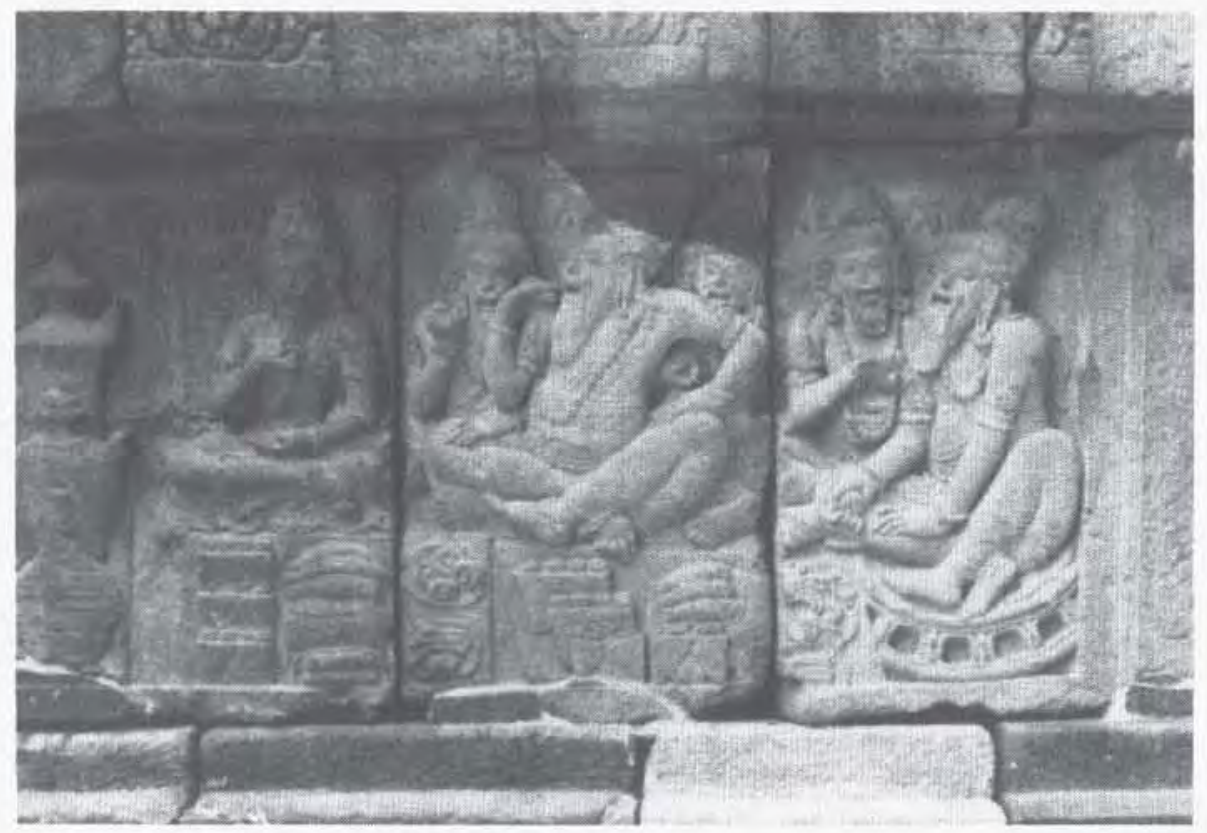

Photo 6. The closing scene of the Rãmãyana: fish eating Brahmans (photograph by Piet Holthuis) 


\section{a. Narrative reliefs}

The narrative reliefs have traditionally received the most attention. Groneman, who is primarily known as the person responsible for the disastrous clearing of the temple area, was the first to recognize the figures of Hanumãn. Rãma, and Sìtă in some of the reliefs and to establish a connection between them and the Indian epic, the Rãmāyana.

Several scholars have expressed surprise at the presence of Rāmāyana reliefs on the Śiva and Brahmā temples, as Rāma has no connections with either Śiva or Brahmā, but rather with Vișn̨u, being one of the latter's incarnations (avatāras) - just like Krșna, whose boyhood exploits are appropriately depicted on the Vișnu temple. Groneman (1893:5), however, did not have any problems with this, because he thought that the Rāmāyana might well be connected with the teachings of Mahãyãna Buddhism, in which the Buddha was regarded as an avatāra of Vișnu as well. What he was implying here was an inversion of the relationship, positing that the Hindu gods depicted on Prambanan were only manifestations of the Buddha, and hence were to be considered as being on a par with bodhisattvas, '[all of them] only modes of being, manifestations of the only, eternal Godhead, the invisible and imperishable Ādibuddha' (Groneman 1893:29). As was stated earlier, Groneman's ideas regarding Loro Jonggrang's Buddhist character were dismissed by Krom as a bold theory. Krom himself stated that it had to be borne in mind that, for those who had delved deeper into these matters, all these gods were nothing but emanations of the one and only Supreme Being' (Krom 1923b:139). The problem is, however, that Krom did not leave it there. Assuming Loro Jonggrang to be a rival monument to Borobudur, Krom came to identify this Supreme Being with Siva, as is clear from his remark about Śiva's pre-eminence among the Hindu triad, namely:

It is perhaps more correct to consider the whole [that is to say, the whole of the temple complex] as being consecrated to the Supreme Being, called Śiva, alongside whom Brahmã and Vișnu, whether or not as manifestations of the same Supreme Being, played a secondary role' (Krom 1923a, I:452),

Following Kern (1888), to whose hypothesis of the fusion of Śaivism and Buddhism in ancient Java both Krom and Groneman referred, I would like to argue in favour of keeping the Supreme Being unspecified as Parambrahma, 'the Universal Soul', leaving open the possibility that Prambanan, comprising Loro Jonggrang and Candi Sewu, may have been a common place of worship for Buddhists and Śaivas alike, A peaceful merging of these religions of this kind seems to me to provide the only satisfactory explanation both for the many architectural and stylistic similarities between Loro Jonggrang and Sewu, and for the occurrence here of gods belonging to the pantheons of both religions. 
'The objects used in worship were partially the same, nct just in appearance, but in reality' (Kern 1888:177). ${ }^{70}$

As was pointed out above, the identification of the reliefs initially took place on the basis of Vālmīki's classic work, which was the reason for all kinds of deviations from this being characterized as 'corruptions' and 'misunderstandings'. This slowly changed after Vogel (1921) made a thorough analysis of one particular relief by reference to various texts (see Vogel, this volume). His article was acknowledged by Stutterheim as a source of inspiration for his $\mathrm{PhD}$ research on Rāma legends and reliefs in Indonesia. In this dissertation, most of the narrative reliefs on the Śiva temple were satisfactorily explained. ${ }^{71}$

The same is not true of the reliefs on the Brahmā temple, which were believed to be a continuation of the Rāma story, and of the Kṛșna reliefs on the Viṣnu temple. Until recently, we had to make do with the tentative and incomplete interpretations of Van Stein Callenfels (1919) and the ill-known interpretations of Indonesian archaeologists as published in workshop papers and locally printed tourist guides (such as by Sugianti 1986; Soenarto 1991; Moertjipto 1991). Fortunately, this unsatisfactory situation will change in the near future with the publication of an article by Fontein, entitled 'Preliminary notes on the narrative reliefs of Candi Brahmā and Candi Vișṇu at Loro Jonggrang, Prambanan' (Fontein, forthcoming).

On the basis of Fontein's still unpublished text, I would note that the Răma reliefs on the Brahmã temple are indeed a continuation of the tale begun on the Siva temple, albeit in a more fragmentary form. Not only does the story seem to flow less smoothly here than on the Siva temple, but the sequence also appears to be discontinuous, as a new episode starts precisely in the middle of the total of 30 reliefs. Where the first relief starts with Vibhisṣana's defection to Rāma's side, and the 15th relief with Rāma's enthronement after his return to Ayodhyā, together with Sitā, the 16 th relief depicts Râma heeding the malicious whisperings of a lady of the court that were to lead to Sită's expulsion from the capital.

Particularly in the second part, there are some reliefs that could not be placed

70 In this context, one should also bear in mind Kern's remark that the 'affinity between Mahâyāna and Śaivism can only be denied if one closes one's eyes', to which he adds, 'the triumph of science does not lie in trying to explain away that which is obvious to everyone, but rather in attempting to go from the visible and undeniable to the causes of observed phenomena.' (Kern 1888:158; see also Coomaraswamy 1986:45.)

71 A summary of this dissertation is superfluous here, seeing that the reliefs are discussed in a translation of Stutterheim's 1928 article, which is included in this volume. Good-quality photographs, with both English and Dutch captions, may be found in, among others, Kats (1925). For the sake of completeness I would mention the recent English translation of Stutterheim's PhD thesis published by the Indira Gandhi National Centre for the Arts, New Delhi, 1989. 
on the basis of texts consulted by Fontein. These texts varied greatly both as to date and place of origin. ${ }^{72}$ The reliefs that could be identified include those depicting Sitā's arrival in Vâlmîki's hermitage; the birth of her son Lava; the sudden but inexplicable appearance of Kuśa, Lava's artificial twin brother; the appearance of the two brothers at Rãma's court, where they recite the Rãmāyana; Rāma's renunciation of the throne; and the closing scene, depicting six Brahmans at a ceremonial banquet to celebrate the accession of Rāma's sons to the throne (see Photo 6).

An as yet unsolved problem is the identity of the text that served as a guide in the depiction of the Rāmāyana story on the Śiva and Brahmã temple. The story of the search for the text that served as a model here is too long and complicated to be recounted in a single paragraph. Hence it will have to suffice to note that expert scholars agree that Vãlmīki's Rămãyana (VR) was not the direct prototype that was followed in the carving of the Răma reliefs, although this, of course, took place in conformity with the general outlines of the popular tale. But here, as always, it is the differences, even tiny ones, that matter and which can show in which direction the search may be fruitfully continued. The study of the origins of the text of the Old Javanese Rämãyana (OJR) is illustrative of this point.

In the OJR, which was written by a Javanese poet who is sometimes, rightly or wrongly, referred to as Yogiśvara, similar, but not always identical, deviations from Vālminki's work were noted. The differences were subjected to a closer examination, which ultimately led to the identification of the text that had served as a model for the OJR. Sarkar, the discoverer of the affinities between some of the verses in the OJR and passages in the Bhatrikãvya (Bhk), wrote about this:

'As similarities in ideas are also matched by differences in details, it is not necessary to admit the physical existence of particular books of even a great poet in Java, as the greatest of the Old Javanese poems, Yogiśvara's Rāmãyana [OJR] is based neither on Vãlmīki's Rãmãyaṇa nor on the Raghuvamśa of Kālidãsa, but on the Bhațikãvya [Bhk] '(Sarkar 1989:42), ${ }^{73}$

\footnotetext{
12 Taking our as yet imperfect knowledge of the origins of the Rãmalyana tradition in Java into account, Fontein, following Stutterheim, adopts an eclectic point of view. Fontein (fortheoming) writes: 'For no matter where it ultimately hailed from, any variant in any text can be of value to us as long as it contributes to the identification and interpretation of the events portrayed in the reliefs.'

73 After Sarkar's casual formulation of this conjecture about borrowings from the Bhattikãvya, in 1934, the linguistic and literary research into the origins of the OJR rapidly gained momentum; however, in regard to some specialized points it has still not been completed (see Vinod Khanna and Malini Saran 1993).
} 
What is important for us is the fact that the Bhk did not serve as a source of inspiration for the Rāmãyana reliefs at Prambanan, either. This conclusion was to be expected after Stutterheim's earlier finding that the OJR (the close relationship of which to the Bhk he did not suspect at all) had not served as a model. How to interpret this fact is an interesting question, about which Fontein says:

'No matter how the exact relationship between text and sculpture should be viewed, the creation of the Old Javanese Rămâyana and the carving of the Prambanan reliefs can now be regarded as two simultaneous, but perhaps independent manifestations in two different media of the Javanese creative response to the impact of Indian epic literature' (Fontein, forthcoming).

With Fontein, I assume that the carving of the reliefs and the writing of the OJR took place more or less at the same time, a definite pronouncement about this being subject to the correct dating of the temple complex. Judging from the results of my recent research into the Buddhist backgrounds of Loro Jonggrang, which were mentioned above, the carving of the Rāma reliefs must have been completed before $855 \mathrm{AD}$, the year in which the Śailendras are thought to have been expelled from Java. The composition of the OJR, on the other hand, took place after that date, either at the end of the 9th or the beginning of the 10th century AD. This dating seems quite accurate with regard to the parts containing the veiled allusions to the religious convictions of the former king Rakai Pikatan 74 , which were skilfully decoded by Aichele (1969), as well as to the detailed description of the temple complex (Poerbatjaraka 1932).

More significant than the fact of the manifestation of the Javanese creative response to the impact of Indian epic literature in two different media, however, is the difference in atmosphere between the text and the reliefs, which is only explainable, in my opinion, in terms of a compensatory artistic reaction to the traumatic dynastical conflict. ${ }^{75}$ While the OJR text, probably because of its subtle metaphorical derisions of the Buddhist clergy, inspired Poerbatjaraka to

74 The rather disparaging way in which the OJR text talks about Rakai Pikatan, equating him with a bird (pikatan) lured by the call of the cuckoo (the Buddhist clergy), would seem only to have been possible after the death of this king and the expulsion of the Śailendras from Java.

75 One may well wonder whether the continued presence of the Śailendras in Sumatra and Kedah, on the Malay Peninsula, could perhaps explain the greater popularity and the stronger literary influence of the Rämāyana in this area, as opposed to Java, where the Mahäbhärata became more popular (Braginsky 1983:31-58), Interpreted in terms of a struggle for national independence, the dynastic conflict may even be brought to bear on Braginsky's analytical distinction between a 'continental' literary system with Sanskrit as the linguistic medium and an insular, Old Javanese system, using the ethnic language (Braginsky 1993:16). 
label it 'fanatically Śaiva', the reliefs have never provoked such an appraisal. On the contrary, most early Java scholars, it may be recalled, stressed the Buddhist spirit of Prambanan's decorative art, particularly of its reliefs. Conceding that for art historians their judgement is still questionable, especially after all that has been said subsequently in favour of Prambanan's alleged East Javanese character, the identification of the reliefs themselves should settle the matter. Unfortunately, it is here that our knowledge, concerning the text that supposedly served as a model for the reliefs, is wanting. Nevertheless, if my thesis about the Śailendra involvement in the construction of Prambanan is correct, it will be reasonable to assume that the Rāma text that was followed at Prambanan must have been more to their liking than the OJR. This then provides a clue that we should look for this text in a hitherto unexplored quarter, namely Buddhist versions of the Răma tale.

So far my explorations in this direction have yielded a few promising results. ${ }^{76}$ Take, for instance, the discovery by Sylvain Lévi of traces of a Rāma legend in a Chinese avadāna text, which demonstrated that 'in the 5th century A.C., the legend of Rāma circulated in certain regions of the Buddhist world in the form reflected by the Ki-kia-ye version' (Lévi 1893:279-81; see also Raghu Vira and Chikyo Yamamoto 1938, IV:5). Among other things, the Chinese texts mention Bharata's visit to the forest to request Räma to return to the capital in order to succeed his father to the throne, and his reception instead of Rāma's sandals. Both these scenes are depicted on the Śiva temple. Similarly, E.B. Cowell (1901:78-82) and S.C. Sarkar (1990:12-3) drew attention to the Daśaratha Jãtaka text, containing another fragmentary Buddhist version of the same episode. However, as differences are of greater relevance than similarities here, conclusive evidence of Buddhist textual influence can only be obtained from a Buddhist story that contains an account of an event that is not found in the VR, the Bhk, or in the HSR, but that is depicted in the Prambanan reliefs. ${ }^{77}$ Such a unique discovery would at the same time refute the still strong tendency to explain any relief that otherwise defy explanation as being the result of local adaptation of an oral tradition.

76. On completion of the manuscript Frank E. Reynolds' (1991) comparative study of Hindu and Buddhist Răma traditions came to my attention, unfortunately too late to be incorporated in the text. His references to several 'Laotian' Buddhist Răma texts, some of which seem to date from medieval times, are particularly interesting for further exploration (1991:53 and 61, notes 9 and 10 ).

77 As a possible example of this I would mention bas-relief No. XIV on the Śiva temple, which Van Stein Callenfels (1922) interpreted as an interpolation of a well-known episode from the Mahäbhärata (see also Stutterheim 1925:135; Kats 1925, no. xxv). Another example is provided by the so far unidentified actions of Lava and Kuśa as illustrated on panels XXV and XXVI of the Brahmã temple (see Fontein, forthcoming). 
Much of what has been said about the methods and the problems of identification of the Rāma reliefs applies also to the Krșnna reliefs on the Viṣnu temple. Actually, the problems here are more complicated, as we have not even an approximate idea which text was followed by the sculptors here. ${ }^{78}$ Most of the reliefs identified thus far illustrate well-known episodes from the life of the boy-hero Krșna, such as Devaki's flight from the demon Kamsa and his henchmen; Devakī giving birth to Krșnna; Kṛsṇa and Balarãma tied to a pounding block; and their subsequent fights against all kinds of enemies (see Van Stein Callenfels, in Lulius Van Goor 1919:39-42; Soenarto 1991:43-55; Fontein, forthcoming).

These reliefs are all found in the first half of the balustrade, and culminate in the episode of the death of the demon-king Kamsa, depicted in the fifteenth relief, which prompted Fontein's perceptive observation that the distribution of the reliefs here is exactly the same as on the Brahmã temple, where the reliefs culminate (albeit temporarily) in the scene of the happy reunion of Rāma and Sitā in the fifteenth. This is further proof of the careful planning that went into their arrangement.

Unfortunately, so far none of the other Kṛșna reliefs have been identified. Considering the identical distribution of the reliefs on the two temples, Fontein suspects that the sequence of the themes corresponds 'grosso modo with that given in the Prambanan Life of Krșna, just as the reliefs of Candi Brahmā follow the general flow of the narrative in the Rāmãyana' (Fontein, forthcoming). Fontein himself doubts, however, whether this may eventually provide a clue to the identity of the textual source, just as he doubts this with respect to the episodes of the story that the sculptors omitted. One of the famous episodes that is conspicuously absent, he noted, is the Govardhana story, in which Krsșna lifts the mountain of that name to provide shelter for the cowherds and cows during the seven days of rain produced by Indra. Another remarkable omission is the scene of the Gopis and Rādhã.

I have little to add to this, except to say that, just as in the case of the Rämäyana, the eclectic search for the prototype text should be extended to include Buddhist versions of the Krssna story. One such Buddhist story is the Ghata Jātaka, where Vasudeva and his brothers are said to be the sons of Kamsa's sister Devagabha and Upasagara (see Bhattacharya 1978:179). Needless to say, Indian Buddhist sculptural art should be examined as well. Several Kṛșna reliefs were in fact discovered among the ruins of the Pāhārpur Buddhist

78 Although it has become customary to refer to these reliefs as the Krẽsnãyana reliefs, Fontein correctly notes that they do not seem to illustrate the Old Javanese text of that name, edited and translated by Soewito Santoso (1986), at all. 
temple, which was referred to above because of its similarity to Loro Jonggrang in architectural design. Curiously, these reliefs included the scenes that were conspicuously absent in Prambanan, such as that of Krșna and Rãdhã (Bhattacharya 1978:179). This matter needs further investigation in order for us to be able to establish whether the Pāhārpur reliefs followed a different textual tradition or whether they attest to a selective adoption of literary elements. ${ }^{7 y}$

\section{b. Iconic reliefs}

Among the more or less independent reliefs which I have labelled 'iconic', the lokapäla (guardians of the cardinal points) depicted on the Siva temple have always received the most attention. Studies by Tonnet (1908), Soehamir (1948:11; 1954:35), Van Lohuizen-de Leeuw (1955), and myself (Jordaan 1992) have shown that, of the total of 24 reliefs, 16 are intended for a particular set of 8 lokapäla - whence derives their name aștadikpāla, or eight (așta) deities, each of which guards a particular point (dis) or section of the sky. Each of them is depicted twice. These lokapāla are Indra (East), Agni (South-east), Yama (South), Nairrta (South-west), Varuna (West), Vāyu (North-west), Kuvera (North), and İsana (North-east).

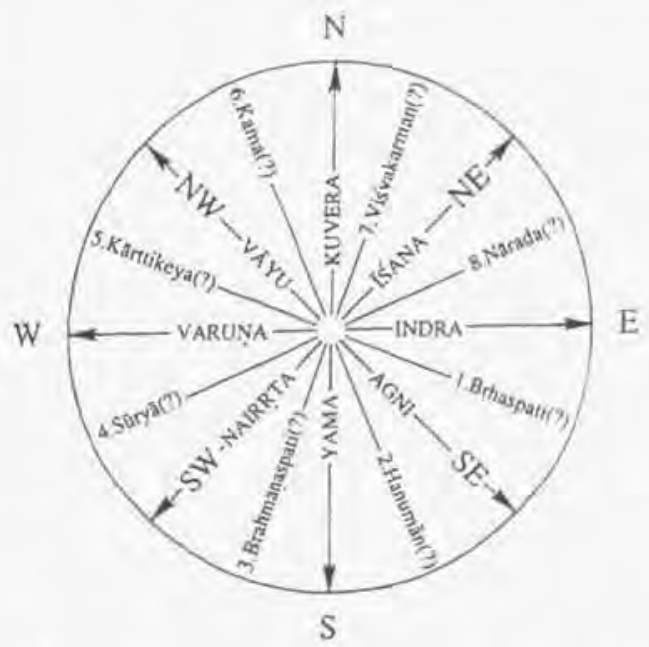

Figure 7. Circle diagram with the names of the lokapâla and their as yet unidentified attendants

79 For a possible parallel 1 would refer to Fontein, who assumed that the monks of Borobudur placed special emphasis on the horrors of hell for the edification of the faithful in Java (Fontein 1989:72-3; see also Gonda 1970:340-1). 
There is still uncertainty about the identity of the remaining eight gods on the panels located between the above. To facilitate a definitive solution, I will give a short summary of the most relevant information. Firstly there is their arrangement. They are placed in such a way as to separate the astadikpäla from each other, resulting in a regular distribution of two sets of eight deities on the inner wall. Tonnet (1908) proposed the following identification of these eight interposed reliefs: 1. Bṛhaspati, 2. Hanumān, 3. Brahmaṇaspati, 4. Sūrya, 5. Kārttikeya, 6. Käma, 7. Viśvakarman, and 8. Nārada (corresponding to plates No. D 2 (Guru), D 5 (Rāma), D 8 (Agni), D 11, D 14, D 17, D 20, and D 23 (Brahmā) in Groneman (1893).

Although Krom considered some of Tonnet's identifications problematic and in need of further corroboration, he did not elaborate upon his misgivings, except to note 'that it is not fully clear how the eight gods [the astadikpâla] were distributed over the twenty-four panels'. The problems were conveniently attributed to the Hindu-Javanese architects with Krom writing: "The designers of the shrine probably had some difficulty with this which might explain why it has proved impossible to discover a definite system at Loro Jonggrang' (Krom 1923a:466-7). Stutterheim also made an ambiguous statement on the subject in a discussion of a particular series of Borobudur reliefs, namely 'that on Prambanan the guardians of the four cardinal points, which are not present at Borobudur, appear in double sets in order to get around some technical difficulty' (Stutterheim as cited in Verslag Congres 1939:32). Just what technical difficulties Stutterheim may have been referring to is unclear.

Van Lohuizen-de Leeuw, who reviewed the identifications proposed by Tonnet in the context of her article on the astadikpāla of ancient Java (1955), apparently did not perceive any technical problem either. She convincingly demonstrated that the architects were wholly capable of evenly distributing the aștadikpāla over the available panels. Regarding Tonnet's identifications of the other deities, she commented:

'Several of these identifications, among which that of Sûrya, we cannot accept; with others we agree. It would involve us in too lengthy a discussion to deal with these eight panels here, and as they do not immediately touch our present subject we prefer to return to them later on.' (Van Lohuizen-de Leeuw 1955:380.)

Regrettably, Van Lohuizen never did, leaving us to speculate about why she believed that the identity of the deities in question did not bear upon the subject of astadikpâla, and why she agreed with some but not with other of Tonnet's identifications - this seeming to imply that the deities were identifiable individually and that they did not necessarily constitute a well-defined group or collective, like the astadikpāla. 
It is easy to see why Van Lohuizen could not agree with the identification of Surrya, although I cannot concur with her arguments for identifying him as the guardian of the Southwest, whose usual guardian is Nairnta. A more appropriate place for Sūrya, in my view, is in the relief located above the lintel of the chamber of Agastya, where Sūrya would occupy a position among the higherlevel gods (see Jordaan and Sedyawati 1990). However that may be, the problem of identifying the deities on the intervening panels remains unsolved.

It seems impossible to make progress by inductively trying to identify each of the deities individually. If one follows this procedure, one arrives at Van Lohuizen-de Leeuw's position, namely that some of Tonnet's identifications are unacceptable, while others are more plausible. This would be a meaningless conclusion as long as it did not uncover the common theme or principle uniting the deities. It seems more logical to start from the premise that these eight figures were not grouped together randomly, but rather constitute a distinetive set, grouped together in this place for a specific reason.

A search of the literature with this premise in mind has not so far yielded any group that might fit these mysterious deities ${ }^{80}$; however, it has made me more fully aware of the Prambanan architects' predilection for the number eight and multiples thereof (see section 8 ). For the moment, this remarkable phenomenon defies explanation, but it may be helpful in determining which Śaiva sect (and school of art) inspired the design of the temple complex, which knowledge will then perhaps lead to the identification of the Ágama or Tantric text we need to solve the problem of the still unidentified reliefs.

In positions corresponding to those of the lokapäla on the Śiva temple, one finds at the Brahmā temple a series of reliefs depicting bearded priest-like figures, whom Bosch identified as r̦și ('seers'), surrounding the god Brahmā (see Bosch, this volume). The corresponding panels on the Vișu temple, each of which shows a male deity flanked by two women, have not yet been identified.

With respect to the reliefs on the two candi apit, one cannot but note a

so Lokesh Chandra, noting that there are twelve Devas or Juni-len in Japan, wondered whether the 24 dikpäla at Prambanan might be these twelve, with two variations each. He further suggested that 'the other possibility is again provided by the Japanese tradition, where each dikpäla is accompanied by two attendants $(8 \times 3=24)$. The entire question needs to be reopened and carefully compared with the Japanese paintings [...] (1989:xiv.) Bearing in mind Loro Jonggrang's possible incorporation in the Dharmadhãtu-vagvisvaramandala, it also seems well worthwhile to do a comparative research of the reliefs on the main temple of Candi Sewu to see whether there too a group of eight deities is depicted, which might represent the Buddhist counterpart of the one found at Loro Jonggrang. Recently, it has been suggested that the reliefs on the sides of each of the four stairways of Candi Sewu's main temple could represent the eight Yakșa kings, who are known as the Mahãyaksasenadhipatis (Anom 1992:62; see also Bhattacharyya 1958:380). 
similar lack of information. It may be of interest to recall the symbolic opposition between these reliefs: whereas the southern temple is decorated with reliefs showing exclusively female deities, the opposite seems to have been true of the northern one (of which only three badly damaged reliefs have survived).

Proceeding now to the exterior of the first sub-basement of the Siva temple, we first encounter reliefs showing delicate figures of dancers and musicians on the outer face of the balustrade, which as was pointed out above, probably illustrate the movements of the Tandava dance. I know too little of Indian and Javanese dance and choreography to be able to determine whether the Tãnḍava really served as a prototype here. In connection with the involvement of the Śailendra dynasty in the construction of Prambanan, however, I wish to remind the reader of Wayman's (1987:472) remark that 'many of the hand gestures and foot stances of Buddhist Tantric practice are also found in Indian dance'. This may well provide the explanation for the remarkable fact that 'the total number of karana (dancing styles or positions) in the dance of Śiva called Tânḍava is 108 [...]. In Tantric Buddhist iconography, the group of Avalokiteśvara manifestations is [aIso] known to number 108.' (Edi Sedyawati 1994:170, note 29.) According to Liebert (1976:294) 'this dance is also characteristic of Vajradhara'. Just as in the case of the Rāma and Kṛșna reliefs, a study of Buddhist Tantric texts could produce useful data for the solution of some of the knottier problems of identification.

It is still doubtful whether the order in which the panels were replaced is altogether correct, as the first Dutch archaeologist involved in the reconstruction of the sanctuary was criticized on this point. One of the annual reports of the archeological service (Oudheidkundig Verslag 1937:6) observes that private research into the meaning and order of the reliefs made it clear that there must indeed have been a system underlying their arrangement and their nature', and that the order observed at that time was so imperfect that there was reason to dismantle the balustrade before continuing with the reconstruction of the temple. In the report for the next year (Oudheidkundig Verslag 1938:7), however, there is mention that this attempt had failed, without apparently further delaying the reconstruction of the temple itself. Immediately after the Second World War, Bernet Kempers again mentioned the dance panels in a short notice in the annual report of the Archaeological Service (Oudheidkundig Verslag 1948:25-7), which, in view of its importance, I reproduce below in English translation:

'The trial reconstruction that had been made with a view to replacing the surface of the exterior of the balustrade of the Śiva temple with the dance panels and the apsaravidyāhara groups had to be undone again because it transpired that it was full of errors. For the sake of a comparative investigation, an attempt was made to complete 
the dance scenes on the exterior of the balustrade of the main temple at Candi Sewu. In this latter enterprise, it proved possible to replace many of the stones in their proper places. Drawings of these scenes have already been made. As in the case of the Siva temple, here also the dancers are all male.

In contrast with the Śiva temple, where almost all the panels show three figures either dancing or making music, these elongated panels at Candi Sewu (four on cach side, making 16 panels in all) depict five dancing figures. The scene is of a bacchanalian character. There are old men dancing as they pour tuak [palm wine] from decanters and drink out of long vessels, which are reminiscent of the longish bronze vessels in the office at Prambanan.

One fragment was found of the panels that were missing in the total of 70 apsaravidyädara groups which contradicts the scheme of their arrangement postulated by Van Erp. Consequently, this system, which had already been rejected by De Haan as well was not taken into consideration in the reconstruction of the balustrade. Of the 62 panels, 21 could be replaced with absolute certainty. In this undertaking old photographs, including those by Groneman, did excellent service, provided they were used with discretion. A plausible location was sought for the remaining panels, though going exclusively by architectural data. This is to say what was looked for were joints that matched up with each other and continuation of the reliefs or omamentation. In the latter instance, there was only the frame ornamentation to go by, but this proved to provide the only reliable clue where the dance panels were missing. Nonetheless, by relying on [the continuation] of the reliefs and ornamentation it was only possible to match up the dance panels with the adjacent stones (with the pilasters and niches of the apsara-vidyädara groups), whereas their placement on the pedestals was still problematic. The amputation of pins and protrusions by earlier restorers posed almost insuperable difficulties. This is why recourse was had to other methods, namely, considering architectural clues. Here the following hypotheses were used as starting point: 1. The niches of the apsara-vidyädara groups must be symmetrical, which means that the pilasters to their right and left must be identical.

2. The ornamentation must have been continuous. In other words, those pilasters whose elements deviated from the normal must have all occurred on the same façade. as the sculptors must have looked to the left and right to check if the pilasters they were making matched the others.

In only a few exceptional cases was it necessary to use the latter hypothesis.

As a final check, the interpretation of the dance scenes may be of relevance. Indubitably what is depicted here is the Tanduava dance of Siva. The "laws" of this dance are recorded in the great book on Indian dramaturgy written by Bharata, the Näfyaśästra. The fourth chapter of this work, which is entitled Tāṇ̦avalakșaṇa, contains a detailed description of the Tãndava. The elements of this dance comprise what are known as karana, coordinations of certain postures of the body (the so-called ariga) and of the limbs and other parts of the body (the so-called upãriga), which one might refer to as dance poses or dance figures. There are 108 karana, each of with its own name. These 108 dance poses, a few of which are claimed to be Śiva's favourite poses, are depicted on the inner walls of the gateways of the Nataräja temple at Chidambaram. ${ }^{\mathrm{RI}}$ On the basis of the lines of poetry inscribed below these panels,

8) Bernet Kempers in this connection notes that: 'The text of the fourth chapter of the Bharata Nâtyašãstra has been published with a translation and copious notes by B. Venkata 


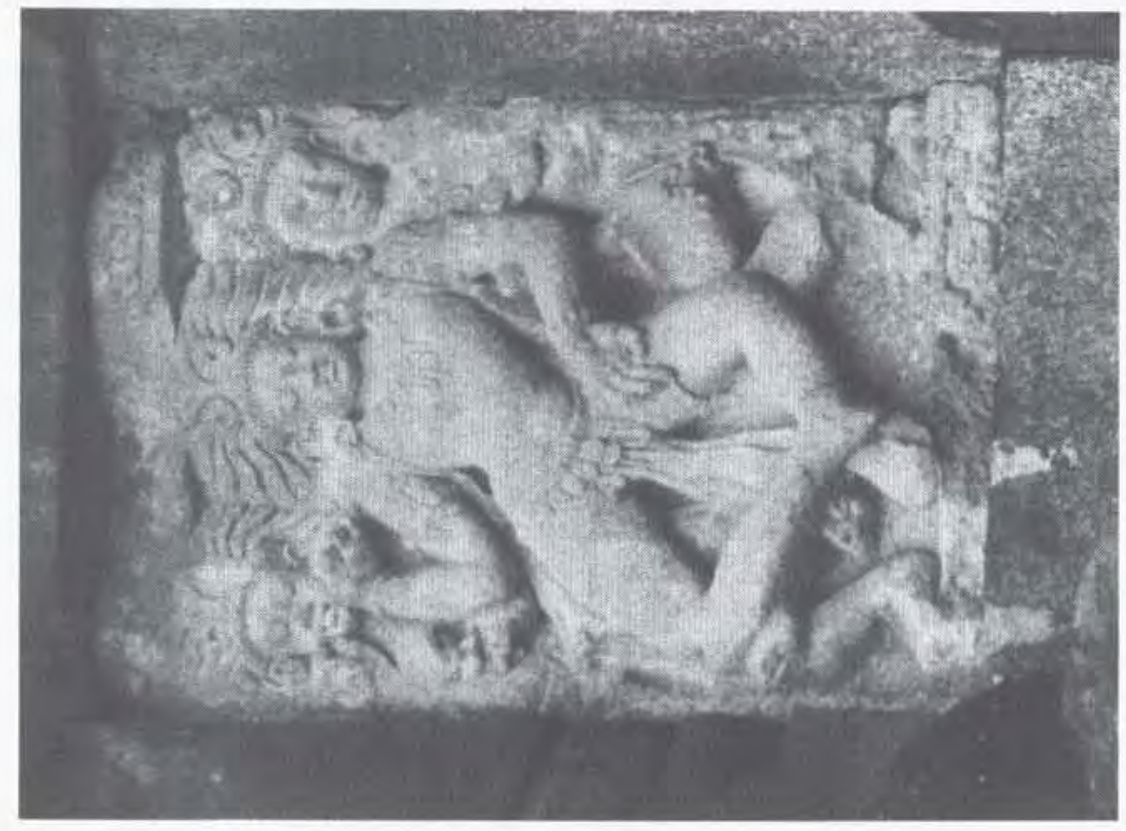

है

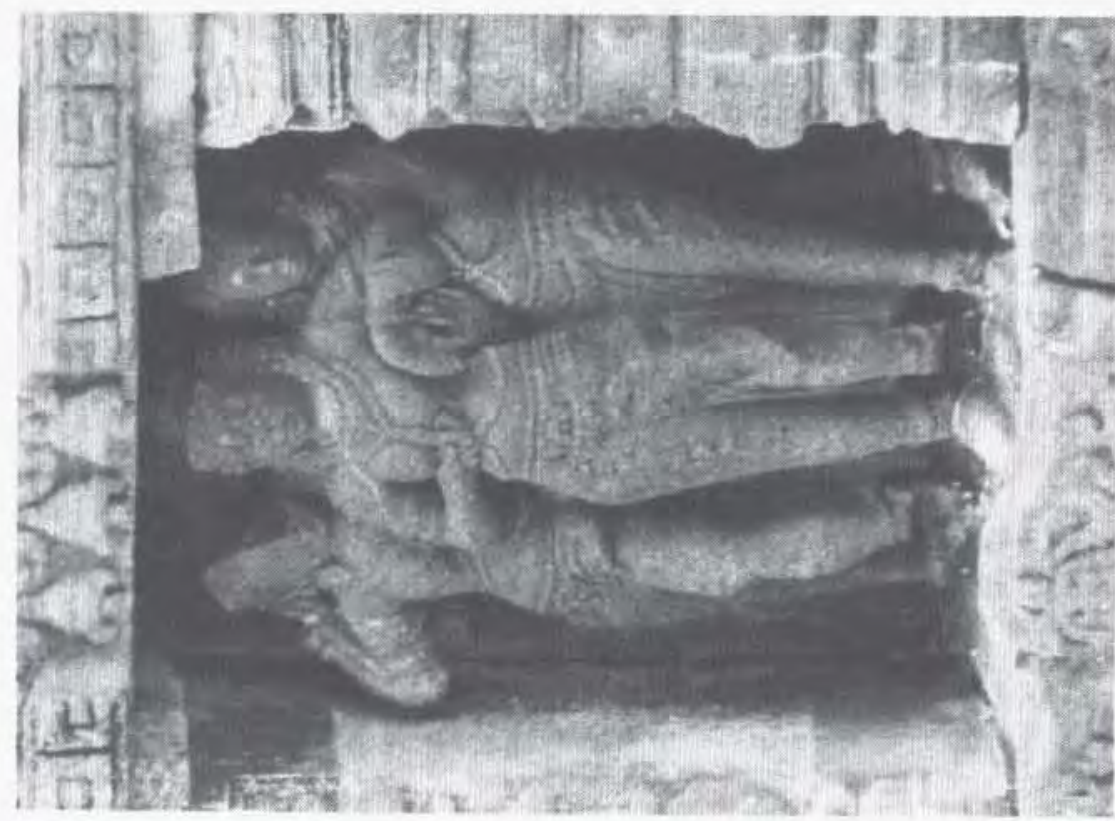


which are quoted from the fourth chapter of the said Nätyasástra, it was possible to find out the names of the dance poses (Madras Epigraphist's Annual Report for 191314). It turns out that many of the dancing figures portrayed on the Siva temple are depicted in a posture that is identifiable with one or another of these karana. Others deviate slightly from certain karana. It is as if we are confronted with a transition from one karana to another, in other words with the dance in performance. The Nāțaśästra also describes 32 classes of karana, called arigahära, the karana in each of which should be performed in a certain sequence. An arigahära thus is a so-called dance motif. Partly in view of the number of dance panels on the Śiva temple (62, hence, if one also counts the two panels that could be imagined in the place of the flanking turrets of the eastem gateway, $64=2 \times 32$ ), I assume that these scenes are identifiable with the various arigahära. This means that there are two panels for the illustration of each arigahāra. The idea is to divide the 32 angahara into fours in each of the quarters into which the balustrade is clearly divided by the four gateways. In the north-eastern quarter there is an average of only one panel for each anigahära, because many of the panels here are occupied by musicians. Naturally the proposed check is far from easy to carry out because one arigahära consists of many karana, and many of these recur in more than one arigahära, which means that it is highly possible for each dance scene to be matched with a number of proposed angahāra. Using this method, after the (architectural) reconstruction, it was possible to place all the dance panels on the basis of the sequence according to the pradaksinā in the correct order of the 32 arigahära (of course it was impossible for karana of each arigahāra to be illustrated on two panels), with the exception of a single panel in the north-eastern quarter. This may be because of a misplacement, though a better placement on the basis of architectural data is not possible for the moment. The fact that the panels of which the placement is absolutely certain fit in with the system is naturally important. Although the placement of the remainder may not be an absolute certainty, the chances that this will become so can be said to be high. A full justification of this reconstruction will be presented in due course by Mr. Samingun,' 82

To my knowledge, only the leading Indonesian archaeologist Edi Sedyawati has concerned herself with minor aspects of this question since $(1973,1981,1993) .^{\mathrm{k} 3}$ In the absence of more detailed information on ancient Central Javanese court and temple dancing and choreography, I must leave this problem for what it is.

Narayanaswami Naidu, P. Srinivasulu Naidu and O. Venkata Rangayya Pantulu under the title Tãndava Laksanam or The Fundamentals of Ancient Hindu Dancing, Madras 1936. Photographs of the Nataraja temple and of the dance scenes depicted on its gateways are also to be found in this book, together with an extract from Madras Epigraphist's Report 1914. The reproductions of inscriptions and woodcuts of the dance panels published with this report are also included in the said book.'

82 I was unable to find out if this latter justification was actually ever presented in writing and is perhaps preserved in some Dutch or Indonesian archive.

83 Professor Edi Sedyawati allegedly also went into the question of the correct order of the dance scenes in her unpublished MA thesis submitted to the Universitas Indonesia (personal communication Professor Boechari). Unfortunately I was unable to obtain a copy of this study, as of some relevant papers (Sedyawati 1973, 1986), and can only report their existence. 


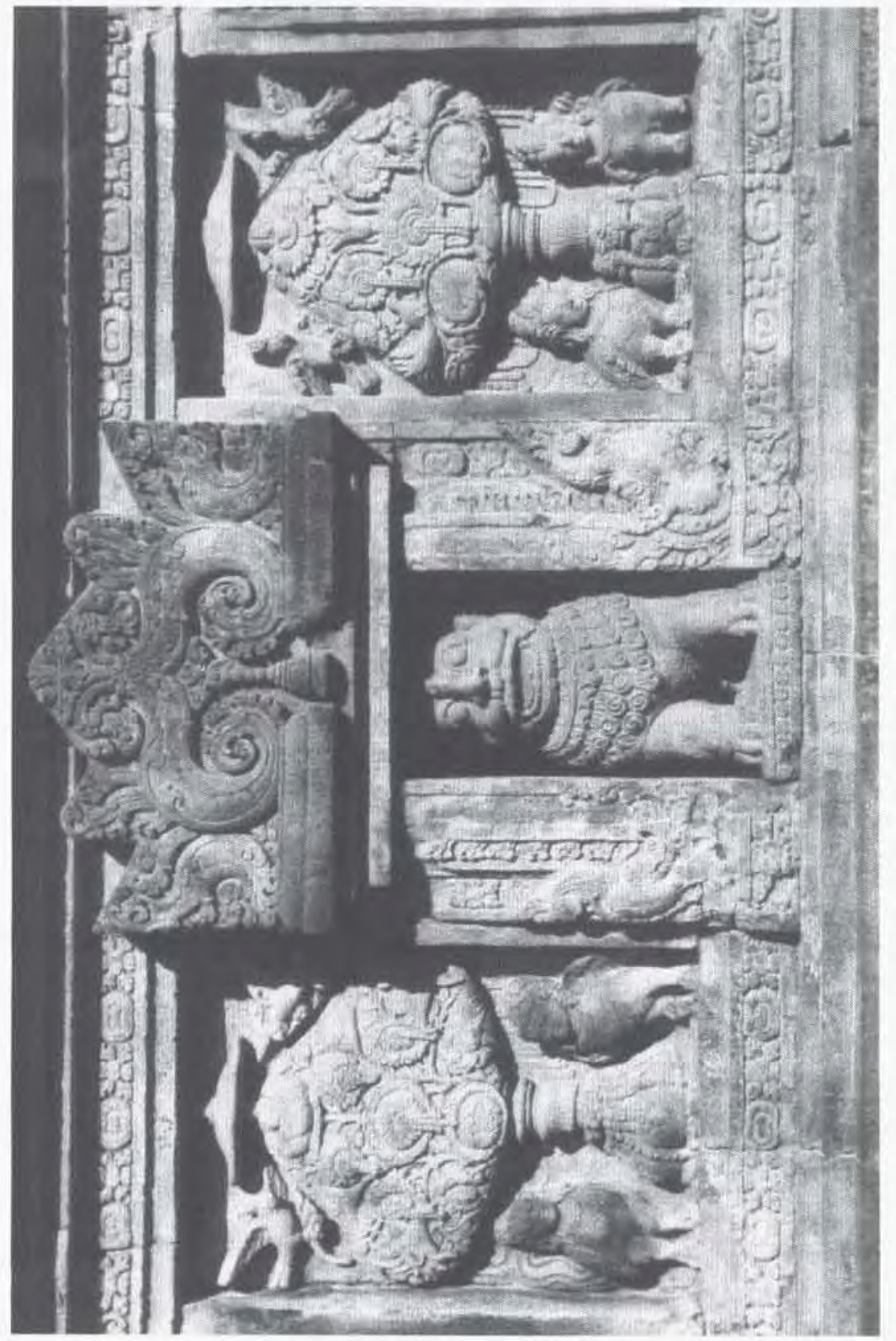

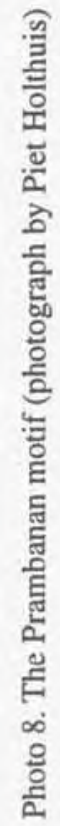


A little further down on the outer wall of the temple one finds countless reliefs of small lions flanked by splendid wishing-trees adorned with gems and with birds in their crowns. To either side of their trunks there are animals, such as rabbits, monkeys or geese, but more often kinnaras, celestial beings with halfhuman and half-bird bodies. Van Erp considered these reliefs to be so characteristic of this temple that he referred to their motif as 'the Prambanan motif. On account of its precision, I will reproduce Krom's detailed description of this feature of the exterior decoration below.

'The motif] consists of a small protruding niche with a lion rampant between two recessed panels which contain a stylized tree between either two kinnaras or two animals. The lions are depicted full face in a standing position as separate items in the opening of the niche, which is flanked by a makara ornament resting on an elongated rosette. The ribbons rising above the makara meet the protruding finial of the niche, which is decorated in the centre with a käla head completely stylized, from either side there appears a spiral motif curling downwards and inwards, representing a pair of inward-turning makara. On either side of this is a similar pattern of outwardly-turned lines replacing a second set of makara heads. From the part depicting the monster's head a bell is suspended. The trees in the simply framed panels beside the niche are shaded by a parasol and emerge from a beautiful flower vase. This fact, as well as the treatment of the subject as a whole as a bouquet, with lotus flowers in four different stages of florescence, might lead one to think of floral arrangements but for the fact that sometimes a bird is shown perched in the branches, which tends to indicate a tree. Small birds in flight are also depicted in the upper corners. The figures on either side of their trunk are kinnara - preferably one male and one female - but also all kinds of animals, such as antelopes, peacocks, rams, hares, monkeys, geese, and other birds. A narrow vertical strip closes off the entire motif on either side, beside which there is a wide, flat strip flanked by two free-standing, chiselled pilasters separating the one group of lion niches and tree panels from the other. The fact of this separation is given added emphasis by the occurrence under both the pilasters and the wide strips - which have been left completely smooth, it should be mentioned - of an upper and lower strip, accentuated by ornamentation in the form of miniature antefixes, and above the flat strips themselves of a small additional frame containing a rectangular ornament provided with an upper and a lower border. In this way the flat strips with their decorative accentuation constitute convenient corner pieces, both on the actual comers of the sub-cella and on those of the salient parts.

In the reproduction of the trees in particular, the motif described here, which recurs on all six of the main temples, provided unlimited scope for variations in details; among the many hundreds of panels, which are basically the same, it would be hard to point out two that are almost exactly alike. The most attention has been bestowed on the motifs of the main temple, where, for instance, the feet of the vases are encircled by smaller vases, and garlands and clusters of ropes fill in the background. In the distribution of the animals flanking the trunk there is question of symmetry on only one occasion. The kinnaras are most frequently on the three great temples. It is impossible to distinguish small points of difference in the treatment of this "Prambanan motif" on the different buildings in other respects as well. For instance, on the three main temples, the makara in the framework of the lion niches retain an animal aspect, 
whereas on the others they have assumed the form of leaf-scrolls, while in the finials of these niches only the makara on the Brahmā and Vișnu temples have been depicted in animal forms, and those on the remaining five stylized as scrolls.

When studying the lion niches, we should also take into account both the small subsidiary temples, which also display this ornament, though without the tree panels, while in the case of the Brahmã and Vișnu temples, by contrast, the medium-sized sections on the corners and sides of the salient parts only have the panel between the pilasters. In the western tier, the lions are represented as free-standing figures, but in the eastern tier they have been fashioned in one piece with the frame. Again, on the subsidiary temples the hind parts, which elsewhere have been rendered quite naturally, are portrayed in rather a childish fashion, alongside the foreparts. Such variations can also be observed in the garlands of the supporting frame, which in the case of the Brahmā and Vișnu temples contain cockatoos, whereas all the others have lotus rosettes. These have been left plain in the northem subsidiary temple.' (Krom 1923a, I:454-6.)

It would be misleading to interpret the Prambanan motifs as mere decorative embellishments. Rather, as was evident from Stutterheim's comparison of Loro Jonggrang to Mount Meru, they should be regarded as fitting symbols of the Cosmic Mountain. They moreover had to be functionally effective symbols:

'Every ancient temple had to be a replica of the World Mountain (Meru or Kailāsa) in order to give the priest the opportunity to invoke Siva to descend on the temple or pseudo Meru. Consequently the architecture and decoration of each temple had to imitate the appearance of the World Mountain as nearly as possible.' (Van Lohuizen-de Leeuw 1957:41.)

Finally, in connection with the temple as a representation of the mountain of the gods (Meru), one more question needs to be raised, namely whether Prambanan was originally painted. This is not the first time this question has been raised. Van Erp (1909:170) and Krom (1923a:475) already mentioned that traces of colour were faintly visible in the main chamber of the Siva temple. Because of the importance of this matter, I will adduce all the available evidence.

First of all, Van Erp (1909:170) observed that, like the gateways, the walls of the main chamber of the Śiva temple were also adorned with flat ornaments of two different design, namely that of a disc-shaped floral motif and that of a modified 'triślacakra, both of which had already been observed on the exterior walls of the principal temple at Candi Sewu'. He further mentioned that, in the ornamentation on the wall, traces could stilt be found of an ancient layer of stucco of a warm, reddish-brown colour, which were especially noticeable after rain. Krom (1923a:475) stated in nearly the same words that here and there are traces still clearly present of a former layer of brown-red stucco, the warm shades of which become visible especially after it has rained'.

These observations provoked a closer examination by the Archaeological 
Service, as is evident from the Oudheidkundig Verslag of 1927. Here Stutterheim writes:

'At Prambanan the theory that the stone surfaces of the buildings were once painted in polychrome was once more subjected to close scrutiny by $\mathrm{Mr}$. De Haan and the undersigned. The principal place in which the presence of a layer of paint had been noted in the past, namely the walls of the central chamber of the Siva shrine, had to be left out of consideration here because it is no longer possible to determine whether the yellow colour that covers the "wallpaper design" here and there is the vestige of an ancient layer of paint or of a more recent layer of ochre applied to the walls in order to facilitate photographing. In respect of the southeastern corner of the foundation, and more especially of the small seated lions in the niches of the main temple, where most of the old stone facing remains, there are five different situations to be observed:

1. all traces of a covering layer have disappeared and the bare stone is visible;

2. a thin, cream-coloured layer of plaster and a very fine gypsum-like substance have been applied to the bare stone;

3. the stone is covered with a thin, red-brown layer;

4. sequence: stone - brown layer of plaster;

5. sequence: stone - plaster - brown layer-plaster.

It is clear that the red coating that is visible where the white layer of plaster has disappeared is not, as has always been supposed, a layer of paint, but was only applied to the stone to "hold" the plaster. It is possible that this plaster in turn served as a basis for a (polychrome?) coat of paint; not the least trace can be found of this, however. It seems most likely to us, therefore, that the temple in its original state was of a dazzling white colour and that there was a much sharper contrast between the light and shady parts than can be created by the dark-grey material that is visible now. Whether the layer of plaster only served to give the structure added beauty or whether it was used as a guard against weathering of the porous material cannot of course be determined now. We only wish to draw the attention of our colleagues to the possibility that a comparison of the treatment of the stone surfaces of different Central Javanese temples may provide clues for the dating - or at least, the classification - of the structures. One cannot fail to be struck, for example, by the fact that at Candi Sewu the same layer of plaster (of a somewhat coarser grain) has been applied as at Candi Prambanan, while at Candi Kalasan and Candi Sari, with their coarse coat of stucco of several centimetres thick, a totally different technique was followed.' (Oudheidkundig Verslag 1927:11-2.)

The temple's 'dazzling white colour' must certainly have made it look magnificent. In any case, the idea seems quite compatible with descriptions like 'delightfulness, eminence, radiance, or ability to eclipse the sun' in many canonical texts, according to I.W. Mabbett (1982:3). Nevertheless, I am not sure if Stutterheim's claim about 'the absence of any trace of any other colour' is justified. ${ }^{84}$ As far as

\$4 During earlier visits to the Siva temple, I was struck by the faint traces of colour on some of the stones above the panels of some of the guardians of the cardinal points. For instance, in D10, Nairta, 1 observed red/yellowish traces, in D12, there appeared to be remnants of a reddish traces behind Varuna's attendants, in D13, the background behind 
the main chamber is concerned, it seems reasonable to assume that Van Erp and Krom were very well able to distinguish the ochre-yellow material that was used for photographing from the reddish-brown colour of the layer of stucco.

It is further difficult to decide precisely what photographs are being referred to here. The most obvious guess is that they were the ones that were ordered by Groneman (1893) from the Javanese photographer Kasian Cephas. In view of the great many photographs that were taken of the reliefs, one wonders just how much ochre may have been used, and if enough remained for the chamber walls. I personally do not know of any close-up photographs by Cephas of the interior of the cellas.

Perhaps additional information may be gathered on this subject from old texts and through mutual comparison of Javanese as well as non-Javanese temples. While the Loro Jonggrang inscription only speaks of the temple as a 'beautiful dwelling for the god', and as being of a 'divine splendour', the superlatives in the above-mentioned description in the Ramayana Kakawin, which refers to such as materials as crystals, gems, and black precious stones, also give us little to go on. In contrast with this, there is Mabbett's information (1982:8) that many sources state the sides of Meru to be coloured as a way of indicating the importance of the cardinal points.

As far as the mutual comparison of Central Javanese temples is concerned, a comparison between Loro Jonggrang and Candi Sewu would seem to be especially logical and promising. It is significant that the features of the ornamentation and the reddish-brown colour of the main chamber can be added to the list of the many similarities between the two sanctuaries that have already been noted. I am able to do so on the basis of the results of recent Indonesian research on the main temple chamber of Candi Sewu, to which I referred earlier in connection with the replacement of the statue of Mañjuśri with that of Vairocana. In free translation, the relevant passage from the Indonesian archaeological report reads:

It is worth noting that the core of the principal temple is constructed of red bricks, while the remainder of the temple consists of andesite. The choice of red bricks for the inner part of the building was certainly not without reason but must have been inspired by specific religious notions. The idea behind the red bricks is connected with the meaning of the temple as a symbol of prakrti, that is, a cosmic element which is the origin of all material objects. As is known, five coarse elements (pañcamahäbhūta) issued from prakrtii: ether or space (äkāsa), air (vāyu), fire (agni), water (āpas), and

Varuna seemed to be reddish whereas the snake seemed to have a vague yellow glow. These observations led later to wonder whether the figure of the god Nairta, who is described as 'a terrifying god of dark complexion', may originally have been painted (see Jordaan 1992:65). 
earth ( $p$ rthivĩ). These five elements are believed to constitute the basis of all that exists. [...] In essence, the red bricks encompass the five elements involved in their production, namely earth, water, fire, air, and ether. Thus the choice of bricks as a symbol for prakrti is quite apt. [...] With its core symbolizing prakrti, the temple is built on a strong foundation based on the prevailing religious notions. Such a temple meets all the requirements of a residence for purusa (god), that is, the spiritual force of the universe.' (Anom 1993:75.)

Leaving an evaluation of this religio-philosophical explanation to others, I only wish to observe that the chambers of the main temples at Candi Sewu and Candi Loro Jonggrang, differ on the point of decoration, the red colouring of their walls, and their usual lack of illumination, from other chambers which have plain, undecorated walls that have been provided with a few projecting stones on which lamps can be placed. These systematic differences are again proof of the strict planning that went into the construction of the Prambanan temples.

\section{General conclusions}

In pushing back the date of the foundation of the Loro Jonggrang temple complex from the middle of the ninth century to an as yet unspecifiable date in the eighth century, we are obliged to make a number of changes to existing theories about the temple and the social conditions under which it was built.

First, the accepted theory that the builders intended the temple complex at Prambanan as a rival to Borobudur is refuted by the new dating. The date of construction of Loro Jonggrang is now seen to be close to that of Borobudur, as well as a number of other Buddhist temples nearer to Prambanan, such as Sewu, Plaosan, and Sojiwan. Instead of a being rival monument, Loro Jonggrang much more likely coexisted peacefully with the Buddhist sanctuaries. Completely consistently with the tolerant religious climate of those days, the Buddhist Śailendra dynasty presumably only permitted the construction of Loro Jonggrang so close to its centre of power because this was not perceived as a threat. This can be deduced from, among other things, inscriptions reporting that the then reigning Śaiva ruler not only was married to a Buddhist princess but also helped with the construction of the Buddhist Plaosan temple complex.

A lack of further epigraphical evidence unfortunately makes it impossible for us to gain a clear idea of the circumstances under which the interreligious cooperation took place or the degree to which the two main religions resembled each other ideologically, or even became assimilated to each other. Whatever the case may have been, the present study of Prambanan has revealed that there are strong indications that this process of mutual accommodation probably commenced much earlier and went much further than has hitherto been 
assumed. These are given not only by the numerous significant architectural and stylistic similarities between Loro Jonggrang and nearby Buddhist temples like Sewu and Plaosan, but also by the recent discoveries of statues from both pantheons on the sites of the Sewu and Sambisari temples.

There is, moreover, the evidence of human sacrifices at the sites of Loro Jonggrang and Sojiwan, which, as I see it, are best interpreted in terms of similar or even identical Tantric rituals. All these data may provide a stimulus to also look at Prambanan from a Mantra Buddhist perspective, as was originally advocated by Moens (1925) and Pott $(1946,1966)$. The long overdue research from this point of view should, in my opinion, concentrate not only on possible connection between Loro Jonggrang and the Buddhist temples in the core area of Prambanan, but also on the temple complex itself. The preliminary results of the exploratory inquiry into Buddhist influences in the decorative arts at Loro Jonggrang are positive enough, I think, to encourage continuation of this investigation.

Just as the new dating of Loro Jonggrang refuted the theory of rivalry between Borobudur and Prambanan, it casts doubt on the theory of continuity in the development of Hindu-Buddhist architecture in Java. After all, one of the strongest underpinnings of this theory was the long current belief in a 10thcentury date for the construction of Prambanan. This assigned the complex a bridge function between Central Javanese and East Javanese temple architecture, the transition between which more or less coincided with the shift of the centre of power from Central to East Java. Before the Second World War it even used to be assumed that Central and East Java were briefly united under the rule of one or more East Javanese kings immediately before this shift. This assumption further stimulated the development of the ambiguous concept of 'East Javanese stylistic traits', in which we can discern a confusion between two things, architectural and stylistic features, that are demonstrably already present at Prambanan and developed further in East Java, being mixed up with elements originating from East Java that were supposedly introduced into the art of Prambanan. Previous research (Jordaan 1993) has shown that the latter are hardly if at all documented, however, and so may be fictions. Consequently, if Prambanan contains elements that are reminiscent of East Javanese temples, this only testifies that not all the principles and techniques of temple architecture were lost with the shift of the centre of power to the east, but that there was continuity of some, albeit a more independent, characteristic sort, soon to find expression in all kinds of new ways. Nevertheless, because this continuity is manifested only in rather general architectural aspects and seems to pale into insignificance in comparison with the many and more obvious differences between Central and East Javanese temples, we have no valid reason to speak 
of a clear continuity in art-historical development any longer, in my view.

With the elimination of Prambanan as a connecting link, the difference between Central and East Javanese temples becomes much more pronounced. Thus in East Java there are no temples of anything like the same dimensions (especially height) as Prambanan and Borobudur. Panataran is the only East Javanese temple complex that approaches Prambanan at all, at least as far as surface area is concerned. The orientations of and spatial relations between the temples in this complex are totally different and much less systematic, however. The ornamentation of Panataran, especially the art of its reliefs, is typically East Javanese and is hardly comparable with that of Prambanan.

In a way, this conclusion implies a return to and a strengthening of the theories of Van Erp (1921:11-2) as well as the views defended by Stutterheim (1925) in his dissertation but erroneously abandoned by him later. The question aside whether the Śailendras were of foreign origin - which in Sarkar's (1985) as well as my opinion can be answered in the affirmative - Prambanan offers incontrovertible testimony that the differences between Central and East Javanese temple architecture are so numerous and so fundamental that they can only be explained satisfactorily by assuming that Central Java was exposed to more direct and vigorous cultural influences from the Indian subcontinent at the time of the construction of Borobudur and Prambanan. This 'classical' period came to a close with Prambanan. What followed was a new, more Javanese form of Hindu-Buddhist art in East Java. 


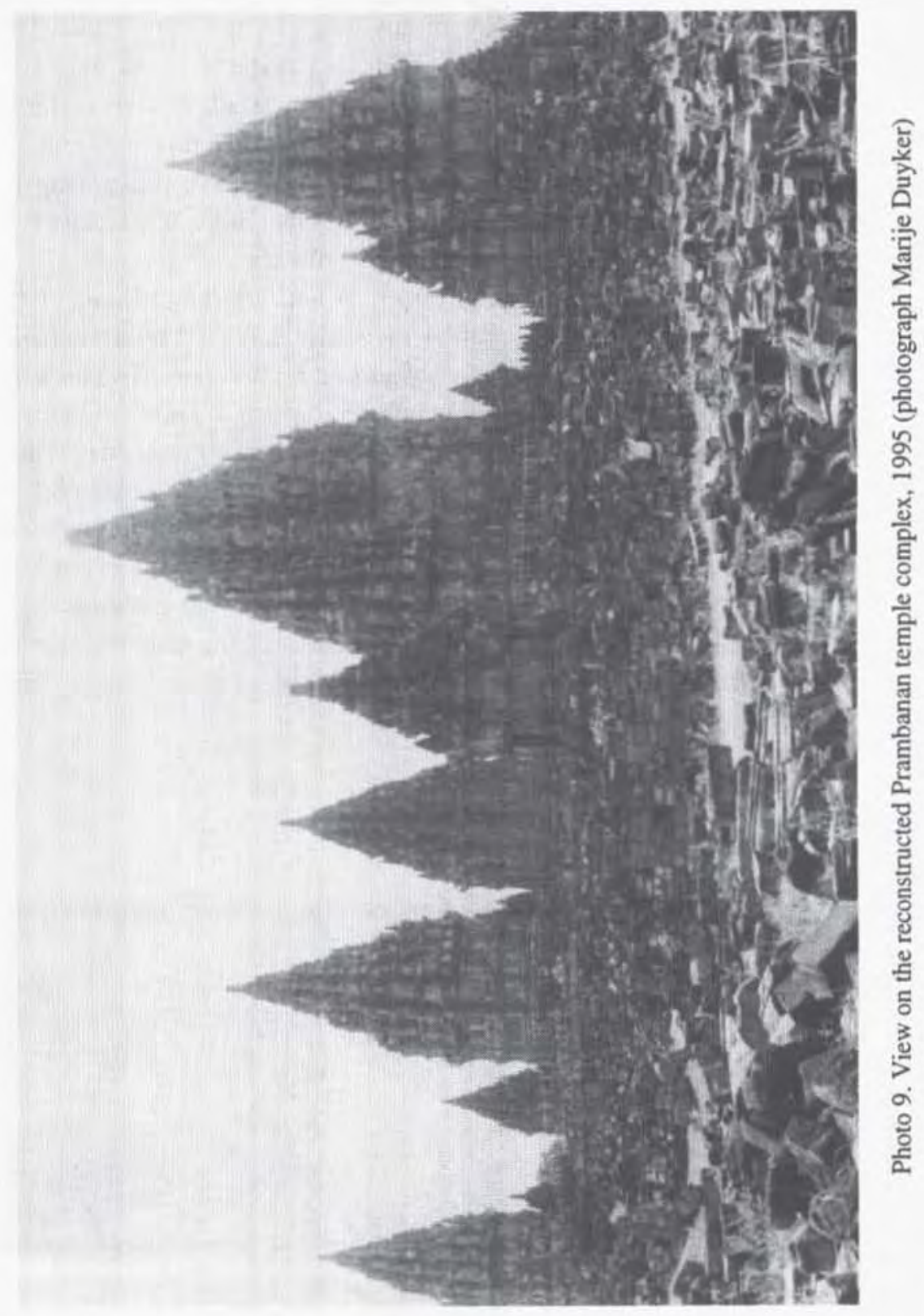




\section{PART TWO}


-978-90- $04-26042-9$

Downloaded from Brill.com๑4/26/2023 02: ०3:20PM via free access 


\section{J.W. IJZERMAN}

\section{The Prambanan temple pits}

As chairman of an amateur archaeological society in Yogyakarta, Uzerman was responsible for the first exploratory excavation of the central temple area of Loro Jonggrang in 1885, in which among other things the temple shafts beneath the pedestals of the statues were partially cleared out. The results of this excavation brought about a complete change in the existing ideas about Loro Jonggrang. First of all, the discovery of a statue of Śiva Mahädeva in the main chamber of the principal temple established the Śaiva character of the temple complex, reversing the hitherto held belief in its Buddhist background. Secondly, the excavation of the temple shafts and the discovery in them of small stone caskets containing ashes and charred bones gave a new impetus to the vague suspicion that Prambanan might be a royal mausoleum.

It has only recently been realized that these two ideas were not borne out by the facts, and are in need of a fundamental reconsideration. When re-reading Izerman's report, one will be struck by a number of comments that are quite compatible with the findings of recent research, and which show that IJzerman was much more subtle and circumspect than some of his contemporaries and successors who made use of his work. Thus, in deciding on the Śaiva character of the temple complex not enough attention seems to have been paid to his comments about Buddhist influences on the art of Loro Jonggrang and about a possible peaceful coexistence of these two principal religions. Although IJzerman can be held equally responsible for the further development of the funerary theory into an accepted paradigm, because of his use of tendentious terms like 'urns', 'funerary ashes', and 'funerals', he at least mentions an important problematic aspect in his report. This is the question of why it was necessary to store the presumed funerary ashes so deep down in temple shafts if this could have been done equally well in a place right under the pedestal of the statues. Uzerman further considered the possibility that the presence of human and animal remains had to do with the involvement of a Tantric sect in the construction of the temple, while it was generally assumed at the time (and sometimes even now) that Tantrism only came into full flower in the East Javanese period and thus could have little if any connection with monuments such as Borobudur and Prambanan.

Although the article reproduced here has with time become a 'classic' essay, the decision to include a translation of it here was not made only for historiographical reasons. As was pointed out above, some of Izzerman's conclusions, especially those concerning the contents of the temple shafts, are still relevant to current comparative archaeological research. Precisely because of the relatively careful record that was kept of the excavation of the different temple shafts, it is very useful for comparisons with the results of research on ritual deposits in Hindu-Buddhist temples in Kedah, in the Malay peninsula, such as that by Lamb $(1960,1961)$ - which possibility was pointed 


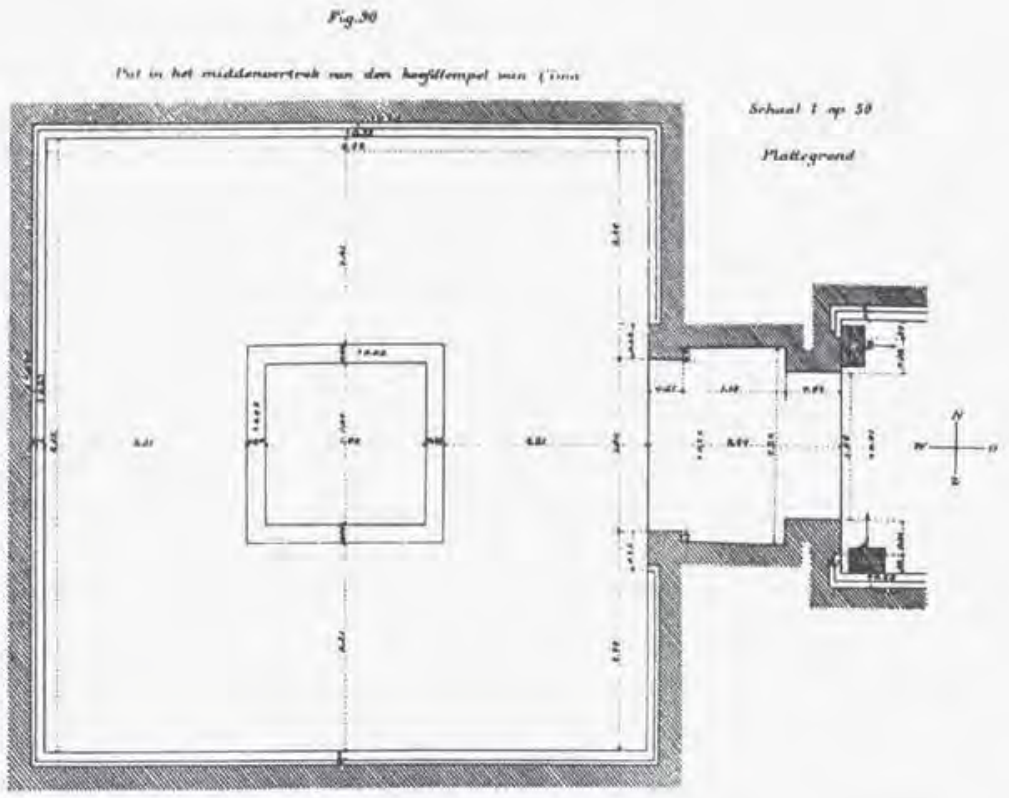

rigs $A$
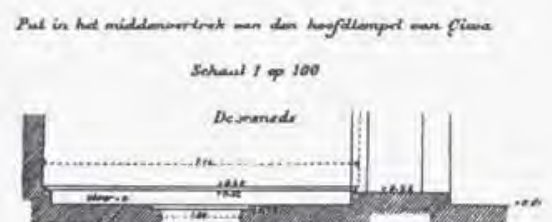

in:-
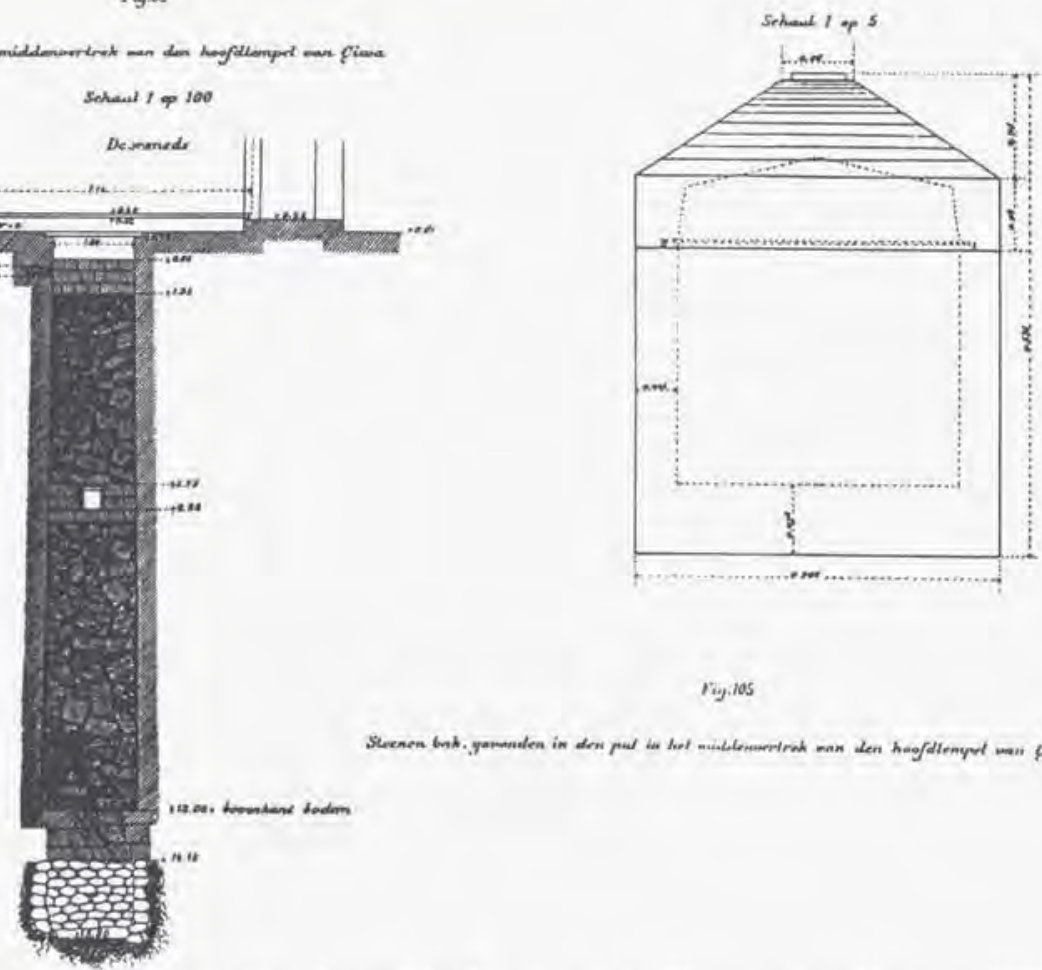

rigings

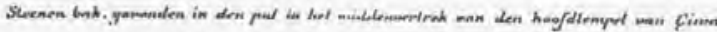

Figure 8. Excavation drawings of the Siva temple by Izerman (see Izerman 1891, vol. 2, Plate XXII: Figs 90-91, Plate XXIII: Fig. 105). (Reduced size.) 
out earlier by Bosch (1961:466, note 2), whose suggestion accordingly, however, has not been followed up partly because of the lack of an English translation. A closer examination of the gold-leaf objects from Prambanan as as well from other Javanese temples may, finally, yield interesting data for comparison with Treloar's (1972) and Riederer's (1994) research findings."

\section{The pit in the Śiva temple}

As was mentioned earlier, when the stones were tidied up it could be observed that the pedestal of the large statue was somewhat tilted, sunk to a depth of about $60 \mathrm{~cm}$ into the floor. Probably some settling had already taken place after the heavy statue was placed on top of the shaft which had been completely filled in, and the fall of the colossal blocks of stone from the roof did the rest. The upper section of the shaft is $1.80 \mathrm{~m}$ square (Plate XXII, Figs 90 and 91, see Fig. 8) and is surrounded by a groove in the floor $20 \mathrm{~cm}$ wide and $8 \mathrm{~cm}$ deep.

Three layers, each about $25 \mathrm{~cm}$ thick, of square-hewn and neatly placed blocks of soft, light-yellow sandstone were found directly under the pedestal, but when these had been removed, there was only soil and stones, casually tossed together. Some of the stones were rough and unhewn, others had been partially chiselled. Different parts of images, such as arms and hands, and of wall decorations and ornaments were discovered below this, and there was a significant number of fragments of oxidized copper scattered throughout it.

The lid of a container $41 \mathrm{~cm}$ long and wide and $53 \mathrm{~cm}$ deep was encountered at a depth of $5.75 \mathrm{~m}$ under the floor (Plate XXIII, Fig. 105, see Fig. 8). The top of this lid, which is made of soft marlstone, is diamond-shaped and a coping of soft, light-yellow sandstone fits onto the container, which was protected from breakage by piles of stones carefully constructed around it.

The soil immediately under this container was mixed with charcoal, and during the excavation small fragments of the burnt bones of animals came to light. In the opinion of Dr Sluiter, who kindly took upon himself the task of investigating these bones at the request of [W.P.] Groeneveldt, in as far as they are recognizable, they seem to be various parts of the forequarters of a goat, namely the ulna with olecranon and a small piece of the upper bone, as

- Excerpt from Beschrijving der oudheden nabij de grens der residentie's Soerakarta en Djogdjakarta. Batavia: Landsdrukkerij 1891, pp. 60-73. Translation by Rosemary RobsonMcKillop. Editor's note: With some exceptions, the very detailed drawings of the results of the excavations are not reproduced here because of their size, number, and complexity. The exceptions are IJzerman's Plate XXII, Figs 90-103, Plate XXIII, Fig. 105, and XXIV. Figs 112-116, on which the contents of the Siva and Vișnu temple pits, among which the goldleaf objects, are depicted. 

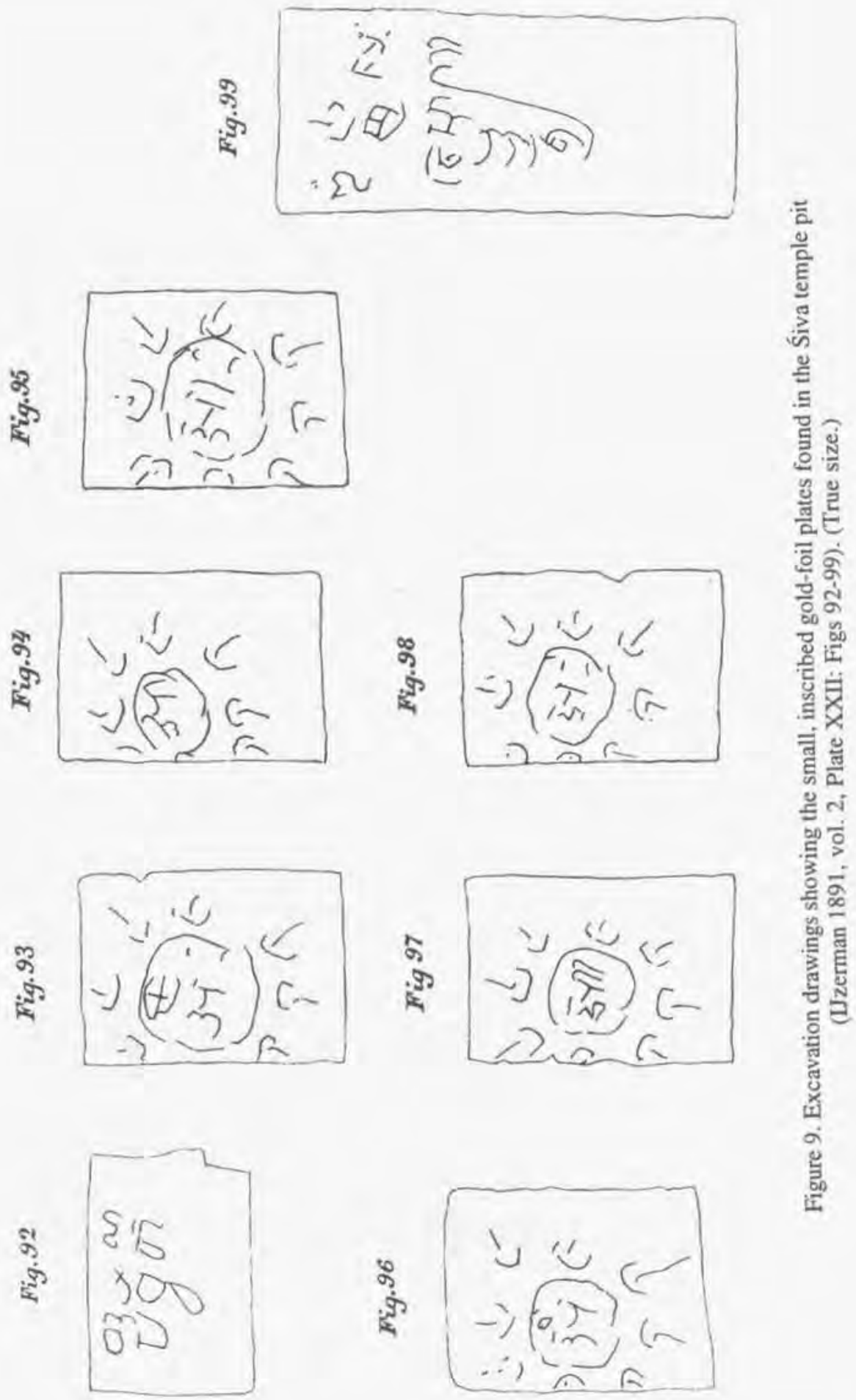


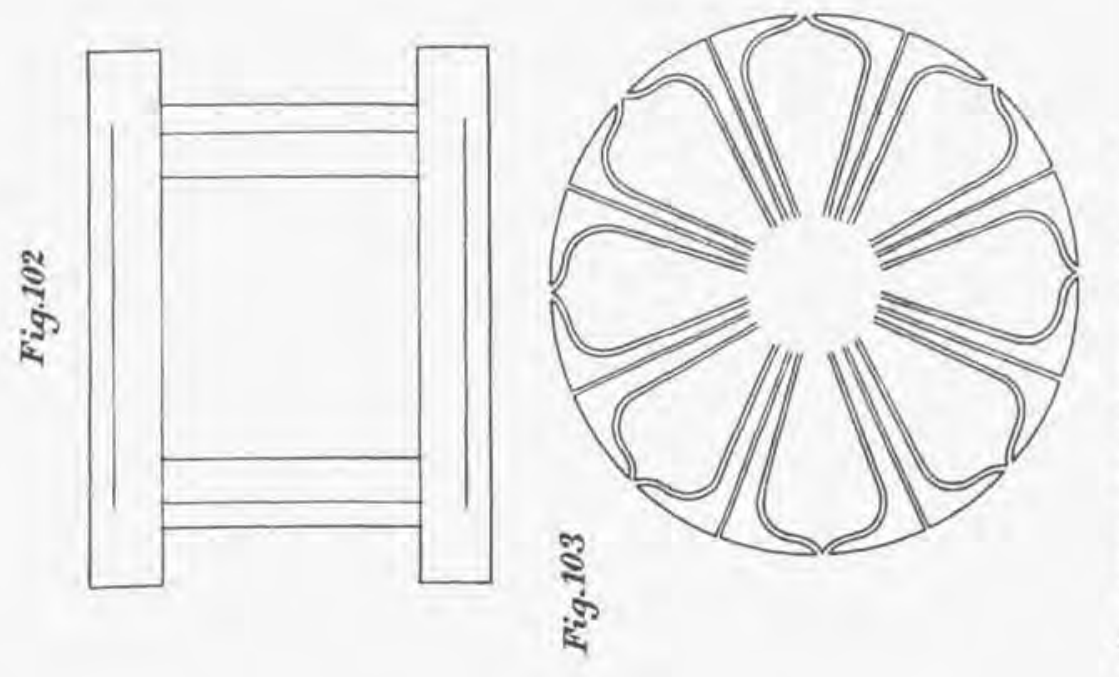

ํ.
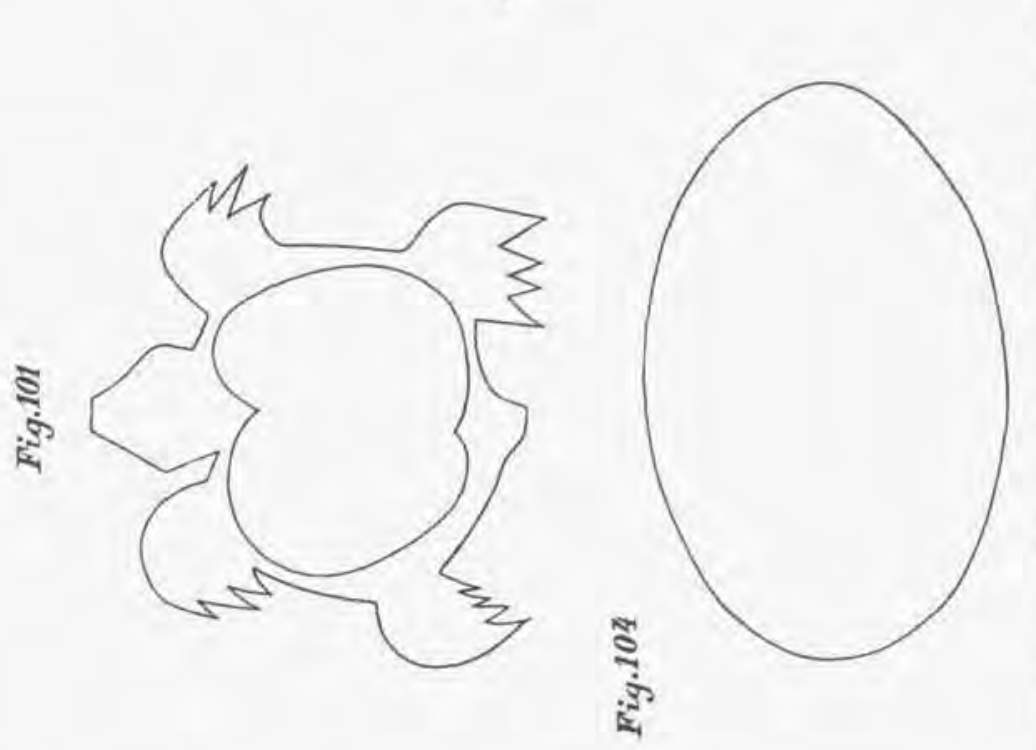

ํㅗำ

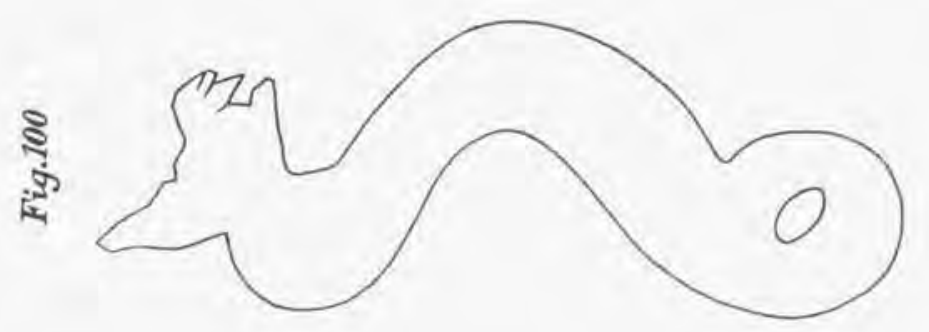

를

जै

해=ㅇㅇㅇ

흐

온

品

¿x

을

은

क

.5

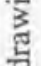

을

챌

소

㟧 
well as calcaneum, a few tarsals and pieces of carpal bones. There was also a piece of the breastbone of a chicken or some other sort of poultry. The species of neither animal could be determined. The bones carry clear traces of the fire to which they were exposed.

Among the remains of the animal burnt offering, there was a small gold plate bearing an inscription, which is shown in Plate XXII as Fig. 92 (see Fig. 9). Apart from this there were no other noteworthy finds in this pit.

The three sherds of various sorts of Chinese ceramics, which were found just below the container, almost certainly found their way there by accident.

The soil level was reached at $13 \mathrm{~m}$. At that point the shaft was more than $2.20 \mathrm{~m}$ square, so that its shape was somewhat pyramidal. The foundation consisted of three layers of stone, which together achieve a thickness of $1.15 \mathrm{~m}$; on digging further, round river stones in sand were discovered and, at $15.90 \mathrm{~m}$, water.

When it was opened, the stone container was found to house partially corroded copper plates, carefully preserved in soil mixed with charcoal and ash. According to Dr Cretier, this soil contains 'carbon, carbonates and phosphates; as well as cleanly cut off fragments of small gold, silver, and copper plates, with larger pieces of badly oxidized copper, probably the remains of the outer casing. When heated the ash yields empyreumatic residues, which indicates an imperfect incineration of animal matter'. It would seem that the inner side of the copper plates had been divided into small square sections, each of which contained a letter symbol.

In the soil were found 20 small, round, concave coins with a diameter of about $15 \mathrm{~mm}$, four with a diameter of $11 \mathrm{~mm}$, and eight with a diameter of $8 \mathrm{~mm}$, stamped on the inner side; some stones of little value, probably from rings, including one with an incised flower'; as well as the remains of other embellishments such as green and other glass beads, clippings of sheet gold and silver, a small natural sea-shell, and most important of all, twelve small gold plates, which are illustrated on Plate XXII, Figs 93-I04 (see Fig. 9 and 10).

Seven of the latter are rectangular and bear letters which have still not yet been deciphered; the remaining five depict a tortoise, a näga, a lotus flower, an altar, and an egg (see Fig. 10).

Although it is not as relevant, one particular pertaining to the floor of the temple behind the pedestal of the Siva statue should be mentioned. When it was uncovered, a small depression was discovered there; when the pit was being cleaned out it was found that the wall on the western side to a depth of about $1 \mathrm{~m}$ was composed of a softer sort of sandstone, instead of the trachyte used for

According to the mining engineer Mr. Schuurman 5 garnets, 2 rock crystals, I diorite. 
the walls on the other sides. Apart from this, the whole surface of the floor of the temple consists of a covering layer $8 \mathrm{~cm}$ thick, except on the western side of the pit, where the depth of the upper surface varies. When the cavity behind the Brahmã image in the southern temple (to be described shortly) became known, it could have reasonably been expected that something similar had come to light here.

However, when several stones, which were separated from each other by a fairly thick layer of earth, were removed, at a depth of $0.94 \mathrm{~m}$, a small area, $46 \mathrm{~cm}$ long and $52 \mathrm{~cm}$ wide, was discovered, which at the front where it meets the pit is $15 \mathrm{~cm}$ deep, and contained nothing but charcoal mixed with earth. There was no trace of any storage place as in the Brahmā temple; the only fact that can be concluded from the above-mentioned observation is that the western part of the central cella was finished and paved at a later time than the rest.

It is possible that the construction served to drain off the water used in the temple into the pit. The generous spaces between the stones, now fairly thick layers of earth, would have facilitated this. The yoni-form pedestal conjures up the image of the statue being bathed with water, as the liniga is in other places, one of the customary forms of worship. The water which was thus sanctified was then perhaps collected here and sold. The water spilled during the ceremony ${ }^{2}$ could have run off through the groove around the top of the pit to the western side, there to be drained off into the soil.

\section{The pit in the Vișnu temple}

Here too the pedestal of the statue had subsided into the soil, albeit only $21 \mathrm{~cm}$. Under the drainage pipe on the northern side of the pedestal was a rectangular depression in the floor, $11 \mathrm{~cm}$ wide and $2 \mathrm{~m}$ deep, which was not connected to the shaft, but to a small cleft in the floor which runs around the whole of the shaft, ending on the western side. This means that it is as if the shaft, which is 1.42 long and wide, is thus encircled by a $13 \mathrm{~cm}$ wide coping. This makes the supposition about the draining off of holy water more probable. Between 0.44 and 0.76 there is a small cavity, which was likewise connected to the shaft and also filled in with earth. More detailed research revealed that it contained a few loose sherds of a broken earthenware pot, a piece of baked red brick, and some charcoal.

When the pedestal was removed, a broken covering piece of martstone was revealed in the centre. This had a $2 \mathrm{~cm}$ wide coping on three sides and it closed

2 If sacrificial animals were slaughtered here, it would require quite a quantity of water to wash away the blood. 
Fig. II?

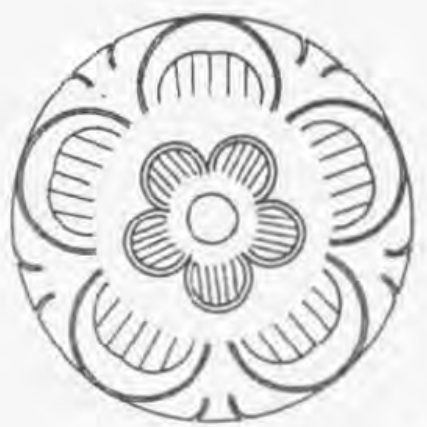

Fig.113

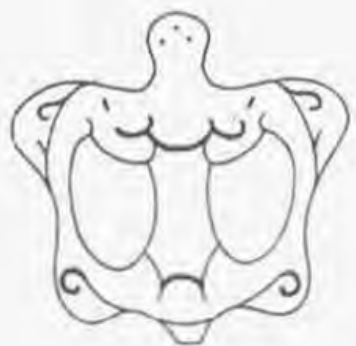

Fig.114

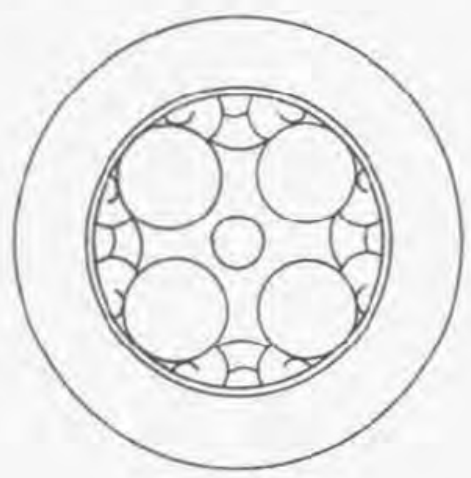

Fig. 115

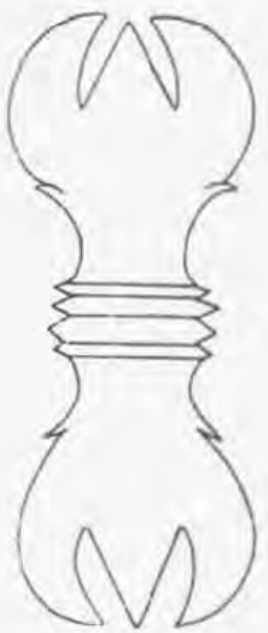

Fig.116

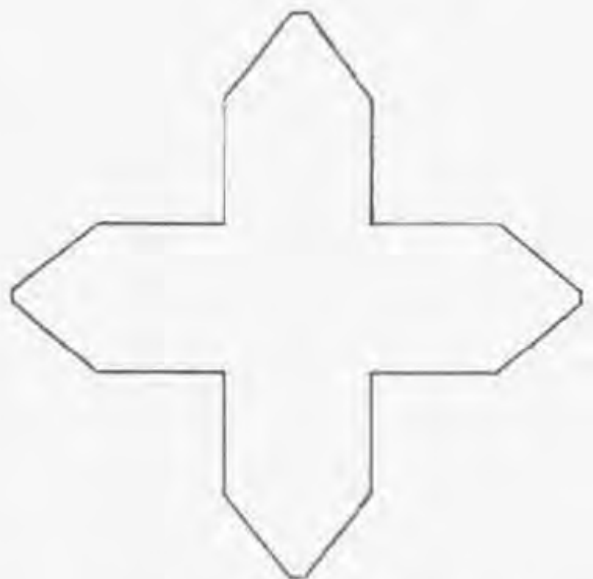

Figure 11. Excavation drawings showing the gold-foil figures in the Vișnu temple pit (IJzerman 1891. vol. 2. Plate XXIV: Figs 112-116), (True size,) 
off a small shaft, $33 \mathrm{~cm}$ square and $50 \mathrm{~cm}$ deep. This small area provided a storage place for a baked earthenware pot of the customary shape in which such pots are still made. The original shape was easily reconstructed from the pieces; at its widest it was $22 \mathrm{~cm}$ round and $18.5 \mathrm{~cm}$ high. At the bottom of this pot (gentong or bujung) was a small copper box measuring $9 \mathrm{~cm}$ in diameter containing ash mixed with soil ${ }^{3}$, as well as the following objects (Plate XXIV, Figs 112-116, see Fig. 11), a gold lotus flower, a silver tortoise worked in relief, a silver disc similarly worked, likewise a vajra and a flat silver cross with triangular chamfered points; besides these there were several stones from rings, some of which showed traces of having been ripped out, including an agate with an incised fish; and finally some silver and gold clippings.

Below the pot were some scattered stones and earth; then at $1.10 \mathrm{~m}$ there was a finely dressed $30 \mathrm{~cm}$ layer of stones, which was separated from a similar second layer by a thin layer of earth. This was situated between 1.75 and $2.05 \mathrm{~m}$ and in its centre was an area $50 \mathrm{~cm}$ square, which narrowed to $30 \mathrm{~cm}$ as it deepened, ending at $2.47 \mathrm{~m}$.

The top section of this narrower area was edged by two layers of finely hewn blue stone, the topmost consisting of eight stones measuring $48 \mathrm{~cm}$ long, $18 \mathrm{~cm}$ wide and $11 \mathrm{~cm}$ thick, while the lower layer was $4 \mathrm{~cm}$ long, $30 \mathrm{~cm}$ wide, and 11 $\mathrm{cm}$ thick. Between the two layers on both the north and the south sides there was a small silver plaque, while on the east side this small plaque was of gold and no larger than a grain of rice.

The space from 1.75 to $2.47 \mathrm{~m}$ was filled with soil which contained a lot of charcoal and a small quantity of copper. At the base of this cavity lay a $10 \mathrm{~cm}$ thick layer of marlstone and under it was a $28 \mathrm{~cm}$ thick layer of sandstone, which brought the depth reached to $2.85 \mathrm{~m}$.

A definite plan to create a cavity could be detected in the next three layers between 2.85 and $3.80 \mathrm{~m}$. Well-dressed trachyte in the centre was surrounded by a coping of softer stone. The first two layers formed a rectangle 74 by $76 \mathrm{~cm}$ with a depth of $32 \mathrm{~cm}$. The third measured 40 by $50 \mathrm{~cm}$ and was $31 \mathrm{~cm}$ thick. A few fragments of decayed wood were found under these layers.

The above was followed by soil to a depth of about $4 \mathrm{~m}$, where a $10 \mathrm{~cm}$ thick curved, fixed layer of fine, brownish-white stone-dust was discovered, followed by bluish-white stone-dust to $4.2 \mathrm{~m}$. Besides this the fill-in consisted of river

3 The chemical analysis showed that the composition of this ash corresponded to that which was found in the pit of the Siva temple. Only in this case there are no largish pieces of copper, but fragments of the earthenware pot instead.

4 The cross possibly represents a svastika, which, however, is usually presented in another manner and is not known in this form. 
stones both large and small, which were mixed with the tusks of a wild pig, potsherds, pieces of chiselled stone, and a few pieces of a broken earthenware pot.

At $7.62 \mathrm{~m}$ there was an irregular plinth, that projected outwards between 13 to $21 \mathrm{~cm}$. At this point the pit had assumed the shape of a square roughly 1.66 $\mathrm{m}$, indicating, like that of the Śiva temple, there has been some expansion. No more stone was found between this plinth and the ground level, which lay 40 $\mathrm{cm}$ deeper, only sand.

In the centre of the shaft a finely worked stone, $39 \mathrm{~cm}$ long and wide and $53 \mathrm{~cm}$ high, protruded from the ground. It rested on a second of the same length and breadth but was $42 \mathrm{~cm}$ high, which in turn stood on yet another of the same dimensions. Between these stones, which as it were indicate the core of the building, lay a mixture of unpetrified lime, which resembled a white dough.

\section{The pit in the Brahma temple}

The pedestal of the main image here had sunk to a depth of $23 \mathrm{~cm}$ into the pit. As in the temple of Vișnu, there was a small depression in the floor under the drainage pipe. During the clearing away of the soil and stones, a piece of one of the smaller Brahmā images was found embedded in the floor behind the pedestal, and after several stones had been removed, including one which had been provided with a $6 \mathrm{~cm}$ round hole, probably for the drainage of the water, a $94 \mathrm{~cm}$ deep cavity was revealed.

In this rectangular hole, measuring $70 \mathrm{~cm}$ long and between 38 and $42 \mathrm{~cm}$ wide, there were a number of baked earthenware pots very similar to the one found under the Vișnu statue, but differing from each other slightly in both shape and decoration. There were four in number, apart from a water pot (kendi) of which only the narrow top section was recovered, which might, however, have ended up here by accident. The earth between the broken urns was mixed with charcoal, a few fragments of copper and flakes of trachyte, the last mentioned will have been used to fix the pots in position.

The cavity described was connected with a similar one in the shaft, which became visible after the removal of three layers of stones from under the pedestal. At this point it should be mentioned that a circular opening had been hewn between the middle stones which was $10 \mathrm{~cm}$ wide at the top narrowing to $6 \mathrm{~cm}$ at the bottom, lengthwise measuring $94 \mathrm{~cm}$ long by $40 \mathrm{~cm}$ wide, and $47 \mathrm{~cm}$ high, which also seems to have been intended to facilitate the drainage of the water. The contents of this second cavity were the same as those of the first behind the statue, with the exception that here were also found a small piece of white earthenware, deriving from a small bowl, and a small piece of a gold coin, 
on one side of which two diamond-shaped impressions had been made next to each other.

Under the level of this particular storage place came a layer of soft, white stones to a depth of $1.95 \mathrm{~m}$, where there was a recess in the fill-in, which showed some similarities to that at a depth of $1.75 \mathrm{~m}$ in the Vișnu pit.

In the $15 \mathrm{~cm}$ thick layer there was also a square hole measuring $33 \mathrm{~cm}$. To the north and south of this hole after the stone layer had been removed, two neatly hewn blue stones, $64 \mathrm{~cm}$ long by $18 \mathrm{~cm}$ wide and $11 \mathrm{~cm}$ thick, were revealed; they were placed in a straight east-west direction. They rested on two smaller stones, which were just as wide and high, but only $28 \mathrm{~cm}$ long, closing off the space on all four sides with two other stones of the same size. The hollow was filled with soil and charcoal, but apart from this contained nothing special.

The soft marlstone continued in regular layers to a depth of $2.78 \mathrm{~m}$, where it was replaced with soil mixed with river stones. To a depth of $3.50 \mathrm{~m}$ in this fill-in there were a few pieces of baked red brick, a small piece of earthenware (kreweng), and one large tooth; at $5.25 \mathrm{~m}$ there was a small quantity of greyblue earth with a few delicate bird bones; at $6.10 \mathrm{~m}$ there was a roughly carved stone pot (lumpang or deplokan), like that still used by present-day Javanese to pound sirih and other leaves finely; at $7.50 \mathrm{~m}$ there was an irregular projection in the side walls which shows that when the pit was constructed the work was not all done according to plan; at $7.80 \mathrm{~m}$ there were a few small pieces of semidecayed bone; at $8.40 \mathrm{~m}$ two rough-hewn cylinder-shaped stones each with a round hole, pieces of a broken kendi and other earthenware; at $9.50 \mathrm{~m}$ there were pieces of a finely made kendi and a piece of bone.

Finally, after river stones had petered out and only sand was recovered from this final section, the ground level was reached at $9.64 \mathrm{~m}$. In the centre rose a stone $36 \mathrm{~cm}$ high and $44 \mathrm{~cm}$ wide; the top was decorated with two intersecting rectangular lines, and indicating as it were the central point of the whole temple building.

\section{The pit in the Nandi temple}

Now turning to the temples on the western side, once again we take the middle and most prominent one as our starting point. The Nandi lies above a pit that is $1.22 \mathrm{~m}$ long and wide, in such a way that the opening of the latter is almost completely closed off.

On the western and southern sides are several steps in the floor, obviously placed there without any thought of order or regularity, and intended to have been covered over after the pit had been filled in. In order to retrieve the proper direction, which had been deviated from, a projection of $12 \mathrm{~cm}$ on the eastern 
side of the pit and one of $10 \mathrm{~cm}$ on the northern side were made at $4.87 \mathrm{~m}$.

At a depth of $5.80 \mathrm{~m}$ there was a quantity of dumped earth, which continued to $9.95 \mathrm{~m}$, the bottom of the foundation. At $8.05 \mathrm{~m}$ was the upper surface of the unfinished base.

The clearing out of the shaft revealed few interesting finds; at $5.90 \mathrm{~m}$ there were the remains of an ant-eater of remarkable size (Manis javanica, a pangolin), uncremated, which died there on the spot, a piece of the lower jaw of a squirrel, two porcupine molars, and a bovine molar; at $7.75 \mathrm{~m}$ there was a small sherd of a broken earthenware pot, and at $8.45 \mathrm{~m}$ a small horse head, broken off from the pedestal of Sūrya.

\section{The pit in the temple of Śiva opposite the temple of Vișnu [Candi B]}

The $1.10 \mathrm{~m}$ by $1.04 \mathrm{~m}$ shaft was completely filled with stones and soil. Neither the pedestal nor the statue was in its original site and it is highly probable that neither of them was ever placed above the pit. Here, once again, the pit has no proper base, which should be located at $7.23 \mathrm{~m}$, and the fill-in begins at the bottom of the foundation at $8.90 \mathrm{~m}$.

A pair of extraordinarily large cornerstones were recovered from the top of the shaft, originating from the roof, at the point where this transforms into the pyramidal vault. Nothing of particular interest was found, apart from the fact that between a depth of $5.30 \mathrm{~m}$ and $6 \mathrm{~m}$ there was an almost complete, wellpreserved human skeleton. Should this be ascribed to a deliberate burial in the pit, or was it chance, an accident, or a crime? Or was it perhaps a human sacrifice, which it is true has long not been the custom in India, but which theoretically is very important in the worship of Kăli, to which the murders of the Thugs bear witness. There is ample room for speculation, which we shall refrain from embarking upon.

\section{The pit in the temple opposite that of Brahmā [Candi A]}

This pit has the same measurements as the previous one, and is surrounded by a neatly finished elevated rim. At $3.68 \mathrm{~m}$ there is a $6 \mathrm{~cm}$ projection in both the northern and southern walls.

To a depth of $5.80 \mathrm{~m}$ the pit was empty and below this there were large stones and soil. At $7.80 \mathrm{~m}$ was the upper surface of the unconstructed base, and underneath this, at $8.40 \mathrm{~m}$ near a colossal cornerstone, was the skeleton of a dog, and deeper at $9 \mathrm{~m}$ the bones of the same sort of animal, neither showing any traces of contact with fire. Even deeper there were several hewn stones of large dimensions. The bottom of the foundation was at $8.90 \mathrm{~m}$ below floor level. 


\section{The pits in the other temples}

The floors of both the small middle temples within the third enclosing wall, which were not raised to any great height above the ground, were so churned up that only in one of them, namely the southern one, could a pit be indicated with certainty.

The small outer temples were also provided with pits. One of them, situated on the eastern side opposite the open space between the Nandi and the smaller Śiva temple, contained a shaft 0.75 by $0.80 \mathrm{~m}$, with a depth of $1.48 \mathrm{~m}$. In this, at a depth of $0.95 \mathrm{~m}$, under a layer of sand and chips of stone, there was a large quantity of ash with pieces of a broken baked earthenware pot and of a small, round, open dish with an upper diameter of about $17 \mathrm{~cm}$ and a depth of $8 \mathrm{~cm}$. A small gold nail was discovered among the ash.

When one compares the pits described above with one another, it immediately becomes clear that there can nowhere be question of excavated pits, but that everywhere it concerns shafts which were [purposely] left in the foundations of the temples. Therefore the depth of the temple corresponds to the height above the ground of the floor of the the temple cella; the deep shafts have to be sought in the main temples.

In the three eastern temples the shaft begins on the same level as the bottom of the foundation, in the three western this was 1 to $2 \mathrm{~m}$ higher. From this one can deduce first of all that the base of the pit was later built up to the desired height - in fact, just before it was filled in. The western pits were never put to their proper use; they were not furnished with urns containing human ashes; they were partially filled in by chance. They are in the same state as the others were before the filling-in took place.

As antithesis to these suppositions it could be argued that the Vișnu and the Brahmā pits were located with great care on a stone base in the centre, the latter even having been provided with two lines which intersected each other at right angles; it might seem that the stones were intended to be the starting point for the checking process for the building of the walls, were it not that none of them have not been carefully worked, which would legitimate a claim for them to be a means to avoid errors. There are irregular projections all over the place, which have been used to rectify mistakes. Therefore it seems probable that the central stones were placed there later, so that in all temples the closing of the pit was simultaneous with the laying of the base of the foundations.

At the top, the shape of the pits is pretty well square. Each side measures 0.25 to 0.5 times the length or the width of the cella in which it is located. In none is the shaft so large that there was no space for the officiating priest. Mr. [J.F.G.] Brumund seems to have assumed the existence of such a set-up in the 
annex of the Loro Jonggrang, where in our opinion, just as in the other annexes, there never was any pit.

The objects which were excavated from the pits in the main temples give sufficient information about the use of the pits. ${ }^{5}$ The stone cist in the shaft of the Śiva temple corresponds exactly to item no. 377 in the collection of the Bataviaasch Genootschap, which was found in the village of Pucung, Ngantang district, Malang; with the sole exception that the latter urn is decorated with a floral border. It contained a square bronze box, a golden ling a and yoni; three small plaques, two gold and one silver, one of them plain the other two inscribed; two small pieces of gold-leaf, one in the form of a tortoise, the other a bottle, and several small silver coins. Besides this one, the Genootschap has two even smaller urns with the same shape, three round ones, as well as a remarkable box resting on a lotus cushion, which is illustrated opposite page 110 in Dr W.R. van Hoëvell's Reis over Java, Madura en Bali, volume 2. This box, which was excavated at Jalatunda by Mr. [W.] Wardenaar, contains nine square sections, all of which contained the remains of ash and calcined bone. In the central section was a round gold box closed by a separate lid. Two other sections contained thin plates of silver which were semi-corroded, while the remaining six sections contained thin gold plates, one of which was decorated with a tortoise, one with a dragon, and one with a lion. All the gold plates and figures were inscribed with letters. Furthermore, small silver coins had been scattered throughout all the sections.'

All these boxes and urns contained the ash of cremated bodies, equipped by respectful and meticulous hands with all the appendages thought to be essential. Veneration of the deceased existed in India long before the advent of Buddhism. According to the Yajurveda, in the ritual for the dead, rice, barley, and a mixture of water and tola (Sesamum indicum) were offered to the shades of the forefathers, both to feed them and to win their favour. A dwelling place for the dead was built in the form of the houses of the living, and from this residence he exercised his influence on the fate of his posterity.

This idea has survived the centuries in a slightly altered form. In his Miscellaneous Essays (Vol, 1, p. 172) Colebrooke says 'that a mausoleum, known as ch'hetri' is often built to honour a Hindu ruler or nobleman; and that it is even more common to erect a temple in honour of the deceased, especially in Central India. And, moreover, that on the site of the funeral pyre a tree should be planted, a block of masonry constructed, a pond excavated, or a pole erected. The bones and ash are gathered in an earthenware pot and buried in a deep hole, later exhumed and borne to the river.'

\section{Compare C. Leemans, Bôrô-Boedoer, p. 431 et seq.}


When the Chinese pilgrim Hsüan-tsang visited the Brahmanic kingdom of Khotan in 510 , he found the same custom. The body of the king was cremated and a temple was built upon the ashes; other deceased were treated in a similar fashion and towers were erected above their remains. In the Mahäbhârata a grave is called a chaitya; in the Rāmāyana the same word is used for temple.

It the dead had power over the living, they themselves needed just as much help and protection against evil spirits or demons. Therefore their graves were surrounded by fences or railings, on which were sculpted protective deities or symbolic animals as guardians. This is the reason that as well as money and precious stones they were given talismen to which great powers were ascribed. Mysterious letter symbols inscribed on the covering of the ashes and on the small gold and silver plates which were mixed up with these, mystical symbols of gods and demi-gods, seem to have been especially efficacious.

In Lillie's Buddha and Early Buddhism there is an illustration of a tortoise, of which the shell is divided into small squares which contain written letters, which Schlagintweit [1881] says that in Tibet are now a prophylactic against evil spirits.

In his monograph about the inscriptions in Java and Sumatra, Vol. XXVI, $V B G$, Friederich recounts: 'During my stay in Bali a cremation of the bodies of a Satria [Ksatrya] family at Kuta in Badung took place. The Pandita Made Alèng Kacèng had already taken up residence in the house of death several days before the cremation. When I went to visit him, I found him occupied with inscribing small gold plates with some letters. At that time, especially because of the presence of a number of other people, I had no opportunity to ask him about the meaning of the letters, and only heard - and this was also confirmed by other witnesses - that these plates, as well as precious stones (whole or smashed into little pieces, rubies in particular) along with other objects, were placed in a small vessel with water, and that because of these ingredients, but above all through the mysterious words written on the small plates, this water was made holy, and later was poured over the body shortly before the cremation. However, it seems that the plates are taken away and are then added to the remaining bones, which are gathered up towards evening.'

It seems that a similar ceremony took place when important people were buried at the time of the florescence of Prambanan. As soon as the pit had been filled in to the required height, the honoured dead could be laid to rest in the place which had been prepared for this purpose.

Why were the pits so deep if the precious ash was to be placed either directly under the image, which would cover the shaft, or at most a few metres below it? It was certainly not a question of saving the masons work; possibly it was to ensure a better drainage for the water which had been used. 
From the calcined remains of animals under the stone storage place in the pit of the Siva temple it can be deduced that an animal sacrifice preceded the burial, and when one compares this to reports from British India, on the grounds of this sacrifice one could conclude that a Tantric sect built this temple. ${ }^{6}$ One searches in vain for similar remains in both other western temple pits.

Instead of stones having been thrown haphazardly together, at a depth of three or four metres, one finds instead stones set together regularly in layers, forming strange enclosed spaces, filled with soil and charcoal. Is it possible to deduce the residue of burnt offerings of flowers and fruit? And what is the significance of the location of the finely hewn stones which are placed at the points of the compass? Could it be that the Prambanan temple group can be seen as a huge cemetery, which was still in use when it was destroyed by enormous earthquakes?

Within the third enclosing wall, under the images of the principal gods was the place of honour, reserved for kings and high priests; in the temple of Siva probably for the kings of Mataram, in that of Brahmā eight of his priests, whose urns were placed there at the same time that the statue was installed. The three eastern temples were still available, waiting until there was a deceased considered worthy to be set to rest in them.

In three consecutive rows lay the principal subjects, between the two inner encircling walls; it seems that the building of the fourth row had scarcely been begun.

The Hindus, like the Christians, preferred to be buried under the vaulted arches of their holy places or in the shadow of the temple gardens outside.

6 Colebrooke (Miscellaneous Essays, Vol. 1, p. 198) referring to the Saktasvin Bhavani: 'The sacrifice of cattle before idols is peculiar to this sect'. And Coleman, Mythology of the Hindus, p. 68 and 94: 'In the immediate neigbourhood of Calcutta, at Kalighat, stands the celebrated temple of Kăhi, on the altar of which myriads of animals are annually sacrificed. On the occasion of the festivals of Kălt her temples are literally swimming with blood'. See also Friederich [1876] about Diëng and Ungaran. 


\section{J.PH. VOGEL. \\ The first Prambanan Rāma relief}

The essay by Vogel reproduced below is the first article to discuss the problem of the identification of the literary text underlying the Rāmāyana reliefs on the Siva temple at Prambanan. Vogel's methods can still be said to be exemplary. Unlike what was usual in his day, Vogel based himself not solely on Vālmīki's classic text, to subsequently attribute the differences between this version of the story and that depicted in the reliefs to personal interpretations and errors on the parts of the Javanese sculptors. Rather, he considered a number of alternative texts, some of which correspond more closely with the scenes in the reliefs than Vãlmiki's text. A few years later, Stutterheim (1925) also included variant versions, derived from oral folk-traditions, in his research on the remaining reliefs, giving due acknowledgement to Vogel for the inspiration he drew from his work."

Anyone who has anything to do with the antiquities of Java will be familiar with the folder of 62 photographs plus captions devoted to Candi Prambanan which was published almost thirty years ago by Dr J. Groneman. The publisher undoubtedly rendered a great service by thus presenting the first clear photographic coverage of a Hindu-Javanese temple. The temple in question is moreover one of the most extraordinary ruins in Java. It displays a series of sculptured scenes depicting the adventures of the divine hero Rāma with such great artistry and vividness as to have no equal even in the Indian subcontinent. It is not detracting from the gratitude we owe Dr Groneman for his publication, I feel, if we observe that his explanations of the reliefs in some respects leave something to be desired.

So we find the following comment on the first relief of the Răma series ${ }^{1}$ :

'In a wilderness characterized by rocks and wild beasts (a snake, a lizard, and birds) we see Garuḍa, the sun eagle and mount (vãhana) of Vișnu, depicted as a man with the beak, wings, and talons of a bird, seated in a respectful posture (silå). He is holding a lotus flower with both hands, which he is turning to his divine master, who, as

- First published as 'Het eerste Rãma relief van Prambanan', Bijdragen tot de Taal-, Land-en Volkenkunde 77(1921):202-15. Translation by Ria van Yperen.

I J. Groneman, Tjandi Parambanan op Midden-Java, na de ontgraving; Met lichtdrukken van Cephas. 's-Gravenhage: Koninklijk Instituut voor de Taal-. Land- en Volkenkunde van Nederlandsch-Indiê, 1893, pp. 9 ff. 


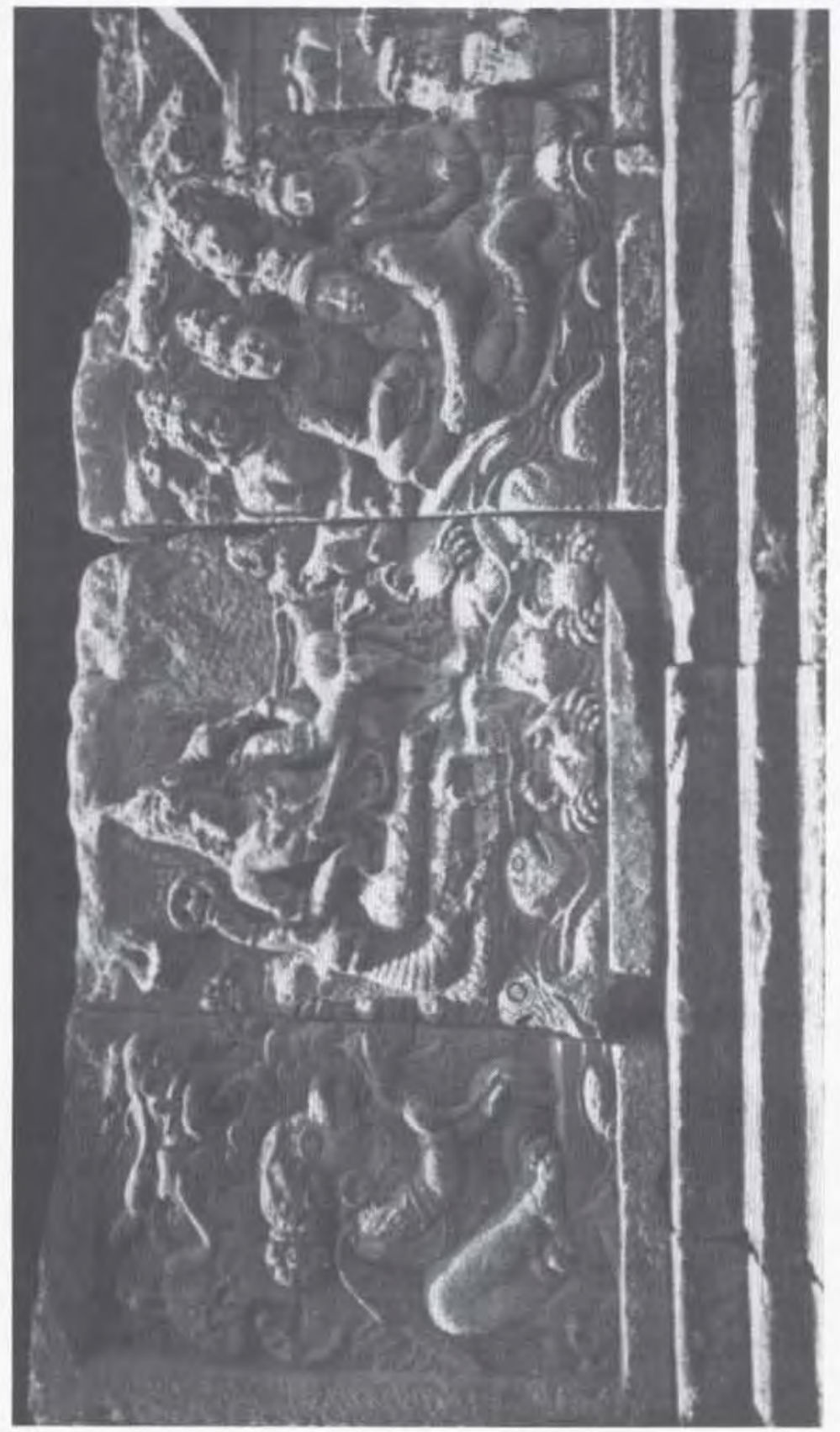

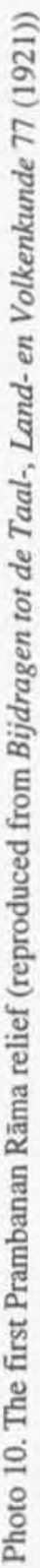


Nārāyana, is reclining upon waters inhabited by marine creatures, bome by the sevenheaded snake Śeșa or Ananta (the infinite).

He is recognizable as such, in spite of the heavily damaged face, by his four hands, of which one, the right rear arm, is holding the cakra or discus, another, the left rear hand, is holding up the sarika or triton shell, and a third, the front right hand, is holding the upavita or sacred cord which is wom across the chest and over the left shoulder by the gods as well as all twice-born (members of the higher castes), while the front left arm is resting on the waistcloth, stretched taut by the drawn-up left knee. The frontward-facing, opened palm of the hand is heavily damaged, and whatever may have been placed in it unrecognizable.

Like all gods, Vișnu Nārāyaña is wearing a crown (makutạ) and royal ornaments.

We know that in his seventh avatära Vișnu manifested himself in the world of demons and men as Răma, and so realize that the Răma legend, the principal episodes of which are depicted in this series of images, must have this god as point of departure.

There are five crowned royal personages (without any aureoles) paying homage to the god and offering him floral sacrifices. One of them - the first - is characterized by a heavy beard as a man of advanced years. The other four are women, although they do not have the full breasts that most Hindu female figures possess. This, like the other extreme - limp, pendulous breasts - is a not unusual feature of these sculptures, however, and is not without a certain significance. This is the more true here, at any rate if I am right in identifying the king as Daśaratha, king of Ayodhyā, praying for children for his three infertile wives. The fourth woman is not mentioned in any of the Rāmāyaña translations and abstracts known to me, but may derive from some other version of the epic. Her crown forbids our identifying her as a servant woman.'

The first part of Groneman's description is correct, save for a few details. A glance at the photograph ${ }^{2}$ [Photo 10. First Răma relief] will show for instance that the world snake Śșa on which Vișnu is reclining is in fact depicted with one head. The three heads emerging to the left of the body of the snake evidently belong to fish, which, together with other marine creatures, so typically characterize the ocean. On either side of the snake's raised neck, however, one can see the typical cobra 'hood' (Skt. phanā or phațā).

Vișnu's front left hand shows no sign of any object, as far as I am able to discern. It is highly improbable that this hand did hold some emblem or other, in fact, as the outward turned opened palm (varamudra $\vec{a}^{3}$ ) has a particular symbolic significance in Indian iconography, namely that of presenting a gift of divine charity. Although as a rule it is the right hand that makes this gesture, the artist apparently took some liberties here in view of the grouping of his figures. The

2 For the photograph reproduced with this article 1 am indebted to Dr F.D.K. Bosch, Head of the Netherlands East Indies Archaeological Society. IOD photograph 3467; see also OD 2127.]

3 It is quite likely that the palm originally had a wheel, a lotus, or some other sign of good lack (Skt. laksana) carved in it. 
meaning of the position of the hand in any case is entirely clear here.

As regards Groneman's interpretation of the group of five figures seated opposite Vișnu, there are serious objections. If one wishes to identify them as King Dasaratha and his three spouses, one has one figure too many. No version of the myth represents Dasaratha as having four wives. Moreover, the figure with the long beard who allegedly represents the king bears much more the character of a Brahman ascetic than of a royal personage, even though his limbs are conspicuously adorned with jewels.

These objections were obviously shared by Van Stein Callenfels, who, in a fairly recent publication of the Dutch East Indies Archaeological Service, has given the following explanation of the relief in question ${ }^{4}$ :

'Vișn u mounted on the world snake, rearing up from the sea, with behind him Garuda. In front of him Rșyaśringa is kneeling, offering him a sacrifice, and behind him is King Dasaratha with his three spouses.'

So in this interpretation in any case the problem of the number of figures is solved. Here the leader and spokesman of the group allegedly is not the king, but the hermit Rssyaśrniga who played the principal part in Daśaratha's sacrifice with the object of obtaining sons (Skt. putrīya ishti). But in that case, how do we explain the representation of this hermit and priest officiating at the sacrificial ritual with ornaments? This objection could be countered with the observation that the seer Viśvāmitra, who figures in the following reliefs (see Groneman: plates XII-XIV), is likewise depicted with earrings and bangles. However, there is a more serious objection, namely that the four figures accompanying the putative Rșyaśringa are beyond any doubt males. So Groneman's explanation that the absence of breasts may have been intended as a sign of the infertility of Dasaratha's consorts, though quite ingenious, was obviously made up to support his assertion. It lacks all foundation.

In order to arrive at a plausible interpretation, we would do well to consult the relevant texts. The first to turn to in this case is Vālmikī's famous Rãmāyana epic. The 15th sarga of the first canto (Bālakānda) runs, in translations:

'Rșyașringa sat lost in contemplation for a moment and, coming to his senses again, spoke to the king [Dasaratha], the sage Veda expert, "I shall perform the sacrifice for the acquisition of sons in accordance with the rite with formulas set forth in the Atharva Veda". He - the glorious one - then commenced the sacrifice for the acquisition of sons and offered sacrifices in the fire with pious acts coupled with sacrificial

4 M. Lulius van Goor, Korte gids voor de tempelbouwvallen in de Prambanan-vlakte, het Diëng-plateau en Gedong Sanga, Weltevreden 1919. A short but accurate list of the Răma reliefs is contained in Appendix 11 . It gives a correct explanation of much that Groneman failed to understand.

5 I have followed the Bombay edition. 
invocations. Then the gods and Gandharvas and the chief of the perfect Rșis assembled to receive their share ${ }^{6}$, in accordance with the rules. Duly assembled at this sacrifice, the divinities spoke these words to Brahmā, the creator of the world: "O Lord, by your favour we are all tormented by a Rākșasa, named Rãvana, exerting great power, and we are unable to castigate him. You have been pleased to grant him one gift, $\mathrm{O}$ Lord, and, always respecting this one gift, we are obliged to tolerate all his actions. He is terrorizing the three worlds, in his folly he hates the supreme [gods], and he is bent on violating Indra, king of the gods. He seeks to outstrip Rșis, Yakșas and Gandharvas, Brahmans and Asuras alike, unimpeachable and bemused because of the gift conferred on him. The sun no longer glows, nor does the wind blow; the ocean, girded with restless waves, shudders ${ }^{7}$ at his sight. Hence grave danger threatens us from that Rākșasa, terrible to behold. You must think of a way of killing him, O Lord."

Thus addressed by all the gods, he [Brahmā] spoke after due deliberation: "Well, I know of the following means of killing the villain. He once said, I want to be invulnerable to Gandharvas and Yakșas, to gods and Râkșasas', to which I gave my consent. The giant in his insolence did not mention human beings; therefore he must be killed by a man. There is no other way of killing him." Hearing this joyful speech by Brahmā, the gods and great Rșis were all delighted.

Meanwhile Vișnu had appeared, full of lustre, lord of the world, resplendent in a yellow robe, holding a conch shell, discus and club in his hands. He had mounted the bird Garuda, like the luminous sun a rain cloud. He was wearing bangles of pure gold. Praised by the supreme gods and united with Brahmā, he stood there attentively. All the gods spoke to him, praising him with bent head: "We want to give you a task, O Vișnu, out of desire for the salvation of the world. There is, O Lord, a King Dasaratha, ruler of Ayodhyā, who is charitable in all his deeds and an expert on the Law, and comparable to the great Rșis in spirit. Condescend to become his son by his three consorts, personifications of Modesty, Fortune and Glory, O Vișnu, and divide yourself into four. Once you have become a man, O Vișnu, defeat in battle that full-fledged thom of the world, Rãvana, who is invulnerable to the gods. The Rākșasa Rāvana, the fool, in the excess of his presumption is tormenting gods and Gandharvas and the perfect supreme Rșis. The cruel oppressor has laid low the Rsis and likewise the Gandharvas and Apsaras sporting in the Garden of Nandana. We have assembled with the Munis with the aim of bringing about his death. Siddhas, Gandharvas, and Yakșas turn to you for protection. You are our last refuge, O Lord, tormentor of foes. Turn your attention to the world of men for the sake of destroying the foes of the gods."

Thus exalted, the lord of the gods, Vișnu, that bull among the celestials, to whom the whole world pays homage, spoke to the assembled gods, with All-Father (Brahmā) at their head and committed to the Law: "Put aside your fear, if you please. For the sake of salvation [of the world] I shall defeat Rãvana in battle, with his sons and grandsons, with his ministers, with his henchmen, kinsfolk and followers - him, who is fierce and unapproachable, who inspires terror among the celestial Rssis. And I shall live in the world of men for tens of thousands and tens of hundreds of years, protecting this wide earth."

6. I have here adopted the reading bhägapratigrahärtham in Von Schlegel's. [1829] edition.

7 I read wikampate here, instead of na kampate. 
So the god - Vișnu, in control of himself - gave the gods a gift and reflected on a place of birth for himself among men. Then, dividing himself in four, [the god] with eyes like lotus leaves accepted King Daśaratha as father. Thereupon the divine Rsis and Gandharvas along with the Rudras and the hosts of Apsaras praised the destroyer of Madhu (Vișnu) with hymns celestial in form: "Slay the arrogant Răvana, him of the terrifying ardour, full of overweening pride, who hates the supreme gods, who has set the world howling, that thorn [in the flesh] of pious penitents, who inspires terror in the hearts of penitents. Slay him together with his forces and followers, this Rāvana of terrifying boldness, who sets the world howling, and, free from fever, ascend to heaven, free from the stains of $\sin$ and guarded by the king of the gods.'

The next sarga then goes on to relate how a strange and wonderful creature appears to King Daśaratha out of the sacrificial fire during his sacrifice. This creature, which is described in detail, introduces itself to the king as 'a man of Prajāpati' and hands him a golden bowl of celestial food (actually, rice pudding). If his consorts eat of this, his wish for sons will be granted. So we see that according to the Rāmãyana version of the story it is not the king, nor the priest Rșyașrnga who turns to Vișnu. It is the gods, with Brahmā at their head, who complain to Vișnu about Rāvanạ's conduct and beseech him to become incarnate in order to rid the world of the demon king.

There are a number of other versions of the popular myth of Rāma besides Vălmikī's great epic in ancient Indian literature. So we find it interpolated in a drastically reduced form as Rämopäkhyãna into the other great epic, the Mahäbhärata. ${ }^{\vee}$ But this mentions only very briefly how the Brahmārșis and Devarșis, with the fire god Agni at their head, come to Brahmā to complain about Rāvana. Brahmā sets their minds at rest by telling them that Viṣnu has already 'descended' to slay Rāvana.

Among the later poems devoted to the same subject, especially Kālidāsa's Raghuwamśa deserves to be mentioned.9 This great poet of classical Sanskrit literature is now generally assumed to have lived as court poet of the famous kings of the Gupta dynasty in the 5th century AD. In his literary epic Raghuwams sa he celebrates the kings of the Sun dynasty, to which according to the myth Rāma belonged. The adventures of Rāma's ancestors, in particular Raghu, are described in much greater detail here than those of the divine hero himself, however, presumably because his deeds had already been glorified in so magnificent a way by the 'father of all poets', Vālmikī. 'What the five main volumes of the great epic relate with the most prolix verbosity, here becomes a 104-stanza

* Mahābhärata III, adhy. 274-291. See also Vishmu Purãna, Wilson's translation, p. 383.

1) Alexander Baumgartner, Das Rämāyana und die Räma-Literatur der Inder; Eine titeraturgeschichtliche Skizze, Freiburg i. Breisgau, [1894], pp. 91-102. Alfred Hillebrandt. Kälidãsa; Ein Versuch zu seiner literarischen Würdigung. Breslau, 1921. pp. 40-66. 
miniature', writes Alexander Baumgartner. ${ }^{10}$ 'It is a most charming, elegant summary, eminently suitable as a quick synopsis of the longer poem. Needless to say, however, it is not a substitute for the latter. One scene follows another in rapid succession. It is impossible for a single motif to be fully developed. Only the battle for Lankā holds its own again here, while many similar features are omitted and everything rushes towards a hasty conclusion.'

It is all the more noteworthy that almost the whole of the tenth sarga of Kălidāsa's poem is devoted to the episode of Vișnu's incarnation as a man, which therefore constitutes a relatively long introduction to his otherwise compressed version of the actual Rāma tale. This circumstantiality gives us nothing to complain about, however, especially the gods' songs of praise to Vișnu (stanzas 16-32) being a gem of classical Indian poetry.

I make so bold as to reproduce the entire passage in translation below.

1. While he (Daśaratha) - equal in ardour to [Indra] the Chastiser of demons maintained a strict discipline over the wide world, a myriad of autumns passed, which lacked but little time. There was nothing lacking in his prosperity, however.

2. He did not, however, acquire that means of redeeming the debt to the ancestors that is called "son" $\mathrm{H}$ - a light that suddenly dispels the dark gloom of melancholy.

3. For a long time the king's propagation of his race remained dependent on external factors, just as the ocean's production of pearls remained unrevealed until its churning [by gods and demons]. ${ }^{12}$

4. As [the king] yearned for the continuation of his line, Rșyaśrniga and the other pious and discreet sacrificial priests undertook to perform the sacrifice for the acquisition of sons.

5. At that time the gods, plagued by the son of Pulastya [Rãvana], turned to Vișnu, as walkers tormented by the heat of the sun to a shade tree.

6. As soon as they reached the ocean, the Primeval creature (Ädipurușa, or Vișnu) awakened [from his yoga sleep]; for vigilance is the distinguishing mark of future battles.

50 Alexander Baumgartner, Das Rāmāyana und die Rãma-Literatur der Inder; Eine literaturgeschichtliche Skizze. Freiburg i. Breisgau, p. 96.

11 An Aryan has a threefold debt to discharge, namely to the gods, the Rșis and the ancestors, which he does by performing sacrifices, studying the Veda, and begetting a son respectively. It is the son who has to perform the sacrifice to the Manes. Cf. Manu IV, 257. and VI, 35-37 [Mânava Dharma-Śâstra].

12 This refers to the well-known myth of the chuming of the ocean (Sanskrit amrtamanthana), at which all kinds of curious things came to light. 
7. The hosts of heaven beheld him seated on the seat made up of the coils of the serpentine beast (the world snake Śeșa), his form glowing with the flashing of the gems in the circle of its hood.

8. Both his feet were embraced by [his consort] Śrī, enthroned on her lotus, with her hands, delicate as young boughs, lying open in her lap, while her waist was covered with fine linen cloth.

9. With eyes like lotuses in full bloom, with a robe softly glowing like the newly risen sun, he resembled an autumn day, lovely to behold at its commencement.

10. On his broad chest he wore that prize piece of the waters of the oceans, the kaustubha gem, whose radiance outshone the Śrivatsa sign ${ }^{13}$ and reflected Lakșmī 's sideway glances.

11. With arms slender as boughs and adorned with celestial jewels, he rose amid the waters like another Tree of Paradise,

12. Whilst shouts of triumph were raised by the arrows endowed with consciousness which had robbed the cheeks of the female demons of the flush of their elation.

13. Standing by his side, with his folded hands meekly raised, was the Garuda bird, still bearing the scars of Indra's thunderbolt, and laying aside his anger visà-vis Śeșa. ${ }^{14}$

14. With his chastening glances, clarified by the end of his yoga sleep, Vișnu favoured Bhrgu and the other seers, who asked him if he had had a pleasant rest.

15. Now prostrating themselves before him, the destroyer of those who despise the gods (i.e., of the Asuras), the gods praised the praiseworthy one, who is inaccessible to all words and thoughts.

16. "Praise be to Thee, Who in the beginning didst create the Universe, Who hast subsequently preserved the Universe, and Who shalt re-absorb the Universe. Praise be to Thee, Who art threefold in essence.

17. Just as the waters from heaven, which have a single flavour, take on other flavours in different kinds of soil, Thou dost assume different manifestations in the basic properties ${ }^{15}$ of things, whilst Thou Thyself remainest immutable.

13 The kaustubha gem adorns the breast of Vișnu, bearing the Śrivatsa sign, which originally doubtless was a sign of good luck (Śubhalaksana).

i4 The Mahābhărata (I, adhy. 31-34) relates how Garud̦a combats and defeats the gods in his quest for nectar (amrta). Indra strikes him with his thunderbolt (vajra), but he loses only one feather. Garuda is the arch-enemy of the Nāgas, but puts this feud vis-à-vis Śeșa, the world snake, aside out of respect for Vișnu.

15 Indian philosophy, in particular the doctrine of Sãmkhya, presupposes three basic properties (guna), referred to as sattva (truth), rajas (passion), and tamas (dark). Cf. R. 
18. Immeasurable Thyself, Thou hast measured the world. Free from need Thyself, Thou art the fulfiller of needs. Unconquered, Thou art invariably the victor. Unrevealed Thyself, Thou art the origin of all that is revealed.

19. Thou dost dwell in the hearts of men and yet art remote. Thou art without desire, and yet dost penance. ${ }^{16}$ Full of compassion, Thou art even so untouched by grief. Existing from of old, Thou even so dost not age.

20. Thou art omniscient and unknown. Thou art the origin of all things and dost exist in isolation. Thou art ruler of all and hast no lord. Thou art one and dost participate in all forms.

21. Hymns of praise are sung to Thee in the seven modes. Thou dost recline on the waters of the seven seas. The fire of the seven rays is Thy mouth. Thou art the sole sanctuary for the seven worlds.

22. The knowledge of which the fourfold group ${ }^{17}$ is the fruit; the four aeons, in which time is reflected; and the world of man with its four castes - it has all sprung from Thee, Who dost wear four countenances.

23. With thoughts controlled by exercise, the yogins have chosen Thee, Who dost dwell in their hearts and art pure light, for their salvation.

24. Who knows Thy true essence, as Thou art unborn and yet dost adopt birth, as Thou art immobile and yet dost defeat those that hate Thee, as Thou sleepest and yet wakest?

25. Capable of enjoying sound and the other domains of the senses, Thou art even so able to do severe penance. Thou art able to guard creatures and yet to keep back in aloofness.

26. The paths leading to perfection are divided into manifold systems, but converge solely in Thee, in the same way as the waves of the Ganges [pour forth] in[to] the ocean.

27. Thou art the refuge of those who are free from passion; on Thee are focused all their thoughts; to Thee are dedicated all their works. Thou deliverest them from rebirth.

28. Thy great power, beginning with the wide earth, is visible to our eyes and yet indefinable. What more can be said about Thee, Who may be known only from the authoritative word of the Veda and from Reason?

29. Thou dost purify man perfectly if he is but mindful of Thee. What abundant

Garbe, Die Sämkhya-Philosophie; Eine Darstellung des indischen Rationalismus, 2te Aufl., 1917. pp. $272 \mathrm{ff}$.

16. The contradiction lies in the fact that Indian ascetics as a rule do penance (tapas) in order to have particular wishes fulfilled, either in life on earth or in the hereafter.

17 The fourfold group (Skt. caturwarga) comprises those four things at which all human effort is aimed, namely dharma (the moral law, moral obligations), artha (material advantage, gain), käma (the pleasures of the senses), and mokșa (release from the cycle of births). 
reward this portends for all other acts performed in Thee!

30. Just like the pearls of the ocean and the radiance of the sun, Thy lofty works are far beyond all hymns of praise.

31. There is not a thing that is unattainable to Thee or remains yet to be attained by Thee. It is sheer compassion for the world of men that impels Thee to birth and action.

32. That words to glorify Thy greatness fail is due to exhaustion or impotence, not to any limitation of Thy qualities." '

The next stanzas of sarga 10 then go on to relate how Vișnu consents to be reborn as Rāma. When the king performs a sacrifice, a creature (here, too, referred to as 'a man of Prajāpati') appears from the fire, bearing a golden bowl of divine food, which he is barely capable of lifting, as it contains the primeval Vișnu within it.

That Kālidāsa's style is very different from the sparer tone of the old epic is obvious. In both, the story line is almost the same, however, save for one striking exception. According to Vālmikī, Vișṇu appears at Daśaratha's sacrifice, where Brahmã and the other gods are already assembled, mounted on the bird Garudia. But in Kālidāsa's version, the gods go to Vișṇu, who, reclining in the ocean, has just awakened from his sleep. In his Meghadúta (stanza 107) as well, Kālidāsa clearly refers to the well-known myth according to which Vișnu - here still clearly recognizable in his original character of solar god - spends the four months of the wet season asleep in the Ocean of Milk. In Indian sculpture as well Vișn is often represented in his magic slumber, recumbent on the world snake Śeșa, whose hood of five or seven snake's heads forms a canopy over the head of the sleeping god, while Vișṇu's spouse Śñ or Lakșmī is holding his feet in her lap. ${ }^{1 \times}$ Generally there is a lotus flower, with Brahmā seated on it, emerging from Vișnu's navel. An especially striking seventh-century representation is found in one of the Pallava rock temples at Māmallapuram, on the Coromandel Coast. ${ }^{19}$ Another well-known example from the first half of the 6th century (hence from the Gupta period) is offered by a relief in the temple of Deogarh. ${ }^{20}$ Likewise, a terracotta panel that once adorned the brick temple of Bhitargaon depicts the same subject in an abridged form. ${ }^{21}$ Facing the sleeping Vișnu here are the Asuras Madhu and Kaitabha armed with clubs. I have moreover found

18. Actually, she is massaging his feet, which, as one Indian editor observes, is 'a service that every Hindu wife considers it her privilege to do to her husband even at the present day'.

19 Annual Report, Archaeological Survey of India, 1910-11, p. 56; p. XXIX b.

20 V.A. Smith, History of fine art in India and Ceylon, Oxford, 1911, p. 162; pl. XXXV.

21 V.A. Smith, History of fine art in India and Ceylon, Oxford, 1911, p. 374; pl. LXXXIV. fig. D. 
numerous representations of Vişnu's slumber in the Western Himâlaya area, especially on stones placed in water tanks. One of the most striking examples is the large stone at the spring of Salhi, in the Sechu Valley, which runs into the upper valley of the River Chandrabhaga or Chinab.22 As is apparent from an inscription here, this figure of Vișnu is referred to as Vișnu Śeșaśãyi, 'Vișnu asleep on Śeșa'.

It is not surprising, therefore, that where Kālidāsa has the gods come to Vișnu with their entreaty, he should have represented the latter in a posture in which he was popularly depicted in sculptures, and which moreover lent itself particularly well to poetic descriptions. Whether he was at the same time perhaps following a literary tradition preserved in the Purānas is not clear, nor need this in my opinion be assumed.

It is most extraordinary, however, that there is a similarity on this point between Kālidãsa's description and the Prambanan relief. Even though there are a few differences - such as the absence of the goddess Śri and the absence of the many-headed hood which the poet describes the world snake as sporting in stanza 7 - the Javanese relief could serve most appropriately as an illustration of the above-cited passage from the Raghuwamśa. The similarity is the more striking when we consider that there are almost no representations of Vișnu asleep in Hindu-Javanese art. The representation moreover deviates from the above-cited passage of Vālmikì's ancient epic, as we saw. Suffice it to add in this connection that there is scarcely any mention of Visnu's avatära in the Old Javanese adaptation of the Räma myth. There is only a brief statement in the opening passages of this poem, made as though in passing, that King Dasaratha was 'Trivikrama's father', 'as he became the father of the god Viṣnu at the latter's incarnation as a man'.

It would definitely be very premature to conclude from the correspondences pointed out above that the Prambanan sculptor was inspired by Kālidāsa here, there being no other sign that the Raghuwamśa was known in Java. It is conceivable that they both drew their inspiration from a literary tradition that has since become lost. It is also quite possible that both the brilliant poet and the consummate sculptor each followed their own inspiration wholly independently of one another here.

It is certain in any case - as it was my actual aim to demonstrate - that the group of five figures facing Vișnu as depicted by the Prambanan sculptor does not represent King Daśaratha with his consorts, but the gods ${ }^{23}$ approaching him

22 J.Ph. Vogel, Antiquities of Chamba State, Part I, Calcutta, 1911. p. 219; pl. XXXI.

23 The absence of the nimbus as a sign of their divine nature seems strange at first sight. But then, the Prambanan sculptor was rather casual in his application of this emblem. He 
with their entreaty. That the request is granted is expressed by the extraordinary posture of the left hand to which attention was drawn above.

The question which then arises is, who in that case is the leader and spokesman of the gods. Going by Vâlmiki, this would seem to have to be Brahmin, and there is nothing in his appearance (except perhaps for the jewellery which I mentioned earlier) that would seem to oppose such an interpretation. However, there is little reason to let Vālmiki have the decisive voice here, the entire representation deviating so markedly from his. As we saw, other Indian sources feature Agni and Bhrgu as leader of the gods as well.

The principal question is whether the sculptor of Prambanan was in fact closely following a particular written text, like the Borobudur sculptor the Lalitavistara in his portrayal of the Buddha legend. Or did he draw his inspiration from the oral tradition that was so very much alive among the Indians and Javanese? In the case of a popular story like the myth of Răma, the latter seems the more likely supposition. If we were to proceed from a HinduJavanese perspective, we would have every reason to identify the bearded leader of the gods as Śiva in the form of Bhattăra Guru rather than as Brahmā.

So there is much about the Prambanan reliefs that still requires investigation and clarification. Now that a fitting monograph has been dedicated to Java's great Buddhist sanctuary Borobudur, nothing would be more welcome to the admirers of Hindu-Javanese sculpture than a fully illustrated and annotated work on the Răma reliefs of Prambanan.

portrays not only Răma, Lakșmana, and Sitā, but also the seer Vi\&vãmitra, and even the king of the apes, Sugriva, with the aurcole, while on the other hand omitting it in his representations of the sea god Sãgara, who definitely has a stronger ciaim to it. 


\section{N.J. KROM \\ The Prambanan statues}

The significance of Krom's work for the archaeology of Java is too well known to need any further elucidation. Until the Second World War his description of the Loro Jonggrang complex, which formed part of his Inleiding tot de Hindoe-Javaansche Kunst provided a useful guide for visitors and students alike. His description of the statues here, which is presented in English translation below, still is today. This part is especially important for its confirmation of the observations of technical and artistic imperfections in some of the statues of the Siva temple by several scholars before Krom, and also for its decision of the question of whether these imperfections are to be explained in terms of errors on the part of the makers or whether they are a result of the fact that the statues we now find here are not the original ones but were installed here later as replacements for others whose identity remains to be investigated further."

[Following the prescriptions laid down for the devotee, Krom has entered the Siva temple by the eastern gateway to circumambulate its passageway pradaksina $\vec{a}$. After his description of the reliefs on either side of the ambulatory, he once more follows the ritually prescribed route for the statues, briefly mentioning Śiva Mahādeva, Śiva-Guru (Agastya), Ganeśa, and Durgã. His more detailed description of the statues follows a different route, however.]

In the west Ganeśa sits on a throne. The god is shown in his usual guise, in which he can be met a thousand times elsewhere in Java: with the skull and crescent moon in his head-dress, the snake caste cord and he is four-armed. In his left front hand he holds a small food dish with the tip of his trunk, in his right front hand is his broken tusk; in his rear left hand is found an axe, and the rear right hand holds aloft a rosary. The bottom of his throne, which is $1.42 \mathrm{~m}$ wide and projects $1.20 \mathrm{~m}$ from the rear wall, is enclosed by the plinth of the chamber, consisting of two flat panels, which passes along it; the front section is decorated with particularly fine foliage; this is connected to the back piece which is decorated with a nimbus and is surrounded by a rim of flames.

The Bhatțăra Guru [Agastya] in the southern chamber stands on a lotus cushion against a backpiece decorated with a nimbus; he wears his usual goatee beard and is fairly heavily built. In his left hand he once carried a water pot, while his right hand holds a rosary against his chest. On the right side against 
the backpiece stands a trident, and a fly-whisk is draped over his left shoulder; on this same side a tip of his clothing blows up against the backpiece. Of the now restored pedestal much less remained than of those in the other two chambers. However, it must have been of the same kind as the thrones of the other two deities; a fragment from the backpiece with a rim of flames shows that stylized makaras once decorated its lower section. However, something peculiar happens here: namely, that the backpiece restored in accordance with the information derived from that fragment does not seem to match with the statue of the god at all; the back section of Śiva-Guru [Agastya] is $80 \mathrm{~cm}$ wide, while according to the backpiece of the throne there should only be an image of 50 $\mathrm{cm}$ in this place.

Remarkably, something similar has also occurred in the northern chamber, which is dedicated to Durgã, the Loro Jonggrang of Javanese tradition. The unquestionably beautifully finished statue of the goddess, once again provided with a backpiece and nimbus, depicts the richly attired Mahișāsurmardiñ standing on the buffalo which is turned towards her left. She has eight arms, and in her right front hand she holds the animal's tail, while with the left she grasps the hair of the Asura, who with club in hand, a chain with a skull round his neck and a striking ornament composed of pointed strips hanging from his belt, stands on top of the animal. In her other hands the goddess has on the right side an arrow, sword, and flaming disk, and on the left side a bow, shield and winged shell. The statue has survived remarkably well; only the nose has been damaged. Although quite a lot of the actual pedestal had disappeared, the form of the backpiece, with its rim of flames and makaras, could be readily discerned. If the statue is placed in front of it, then most of the makaras and the rim of flames is hidden. Whereas there is no doubt that the Ganeśa statue clearly belongs with its throne, this is certainly not the case with the statues in the other chambers. Therefore, one has to draw the conclusion that these thrones were originally intended for statues of more modest proportions, or that the sculptor and the architect failed to take sufficient account of each other's work as the result of some misunderstanding.

On the eastern side, as is also the case at Kalasan and Sewu, the space which corresponds to the above-mentioned chambers serves as the ante-chamber to the actual temple chamber which lies behind it, to which it offers a $1.66 \mathrm{~m}$ wide ingress. On either side of this entrance there is an image of a deity to serve as a temple guard. These are well-known servants, originally manifestations of Śiva; they are about $1.25 \mathrm{~m}$ high, not taking into account the lotus cushion which serves as their pedestal. They are clad in fine array and have a nimbus. The one on the right supports himself with his left hand on a club which has been placed beside him, while he holds his left arm against his body; the one on the left holds 
a fly-whisk, which hangs over his left shoulder, in his left hand, and a rosary is visible in the palm of his right hand, which hangs down held open; on the same side there is a trident depicted on the backpiece. As discussed earlier, these divine figures, like those found at Gedong Songo, Selagriya, and Singasari, should be interpreted as Mahākāla and Nandiśsvara, who are also designated in the Smaradahana as the guardians of Śiva's gate.

At the rear of the chamber one mounts one step and then, having passed along a passageway $2.20 \mathrm{~m}$ long, stands in the actual adyton, which is $7.14 \mathrm{~m}$ square; here, on his pedestal in the middle of the room, the main figure of this sanctuary and thus of the whole temple complex rises in all his glory: Siva as Mahādeva.

Śiva's pedestal is austere and simple; it has the usual yoni form with flat mouldings, including that in the middle between the upper and lower panels. A remarkably fine snake's head, which supports the drainage spout turned towards Śiva's left side, can be counted among the most successful art works in the Loro Jonggrang. The pedestal is $1 \mathrm{~m}$ high; although it was discovered smashed to pieces, the statue of the god as reassembled now measures $3 \mathrm{~m}$. Siva stands on a lotus cushion against a backpiece; his slender body is, of course, attired in a fine costume, with finely worked chains and girdles. A tiger skin is cast around his loins and is visible over his sarong; naturally neither the snake as caste cord, the head-dress adorned with the skull and crescent moon nor the third eye on the forehead have been omitted. The Mahãdeva has four arms; the right front hand is raised in front of his chest and the left, which is held at the level of his belly, carries a round knot; the right rear hand holds a rosary and the left a fly-whisk. Furthermore, on the right side there is a trident against the backpiece.

The internal arrangement of the sanctuaries of Brahmä and Vișnu is the same. The temple chamber, which covers an area of 5.44 by $5.46 \mathrm{~m}$ above the base, is entered through a passage $4.28 \mathrm{~m}$ long and $1.26 \mathrm{~m}$ wide. The walls are smooth, with the exception of two projecting stones $1.58 \mathrm{~m}$ above the floor, probably lamp brackets, in each of the side walls.

In the centre stands a large statue, $2.40 \mathrm{~m}$ high, of the god to whom the temple is dedicated; against the rear wall there are another three smaller representations of the same god. The main image, just like that of the Śiva temple, is raised on a simple, yoni-shaped pedestal, with the spout supported by the snake on the left side of the god; underneath the pedestal is once again the temple pit.

The four Brahmā statues, which remind us that Śiva was also represented four times in his temple (as Mahādeva, Guru, Nandīsvara, and Mahākāla), had all been smashed to pieces. Now the main image has been more or less pieced together; 
fragments of two of the others are still at Prambanan; the third, after various peregrinations, has also returned there. The large statue is naturally decked out with divine panoply and is immediately recognizable by its four heads, the rearmost of which looks towards the backpiece. Writers compete with each other in praising the fine workmanship and the noble expression of this Brahmã image. Of the three smaller images, all of them are $96.5 \mathrm{~cm}$ high and stand on lotus cushions.

The middlemost once had four arms; on his right side was an eight-armed and on his left side a six-armed representation of the god. In his right rear hand the four-armed image has a trident, and in the left a staff; probably, the left front hand hung down with the palm held upwards, while the right probably held a lotus bud. The six-armed statue was furnished with awesome attributes, on the right side a sword, a shield and an arrow, and on the left side a shell and bow, while the sixth displayed a mudrā; five of the hands of the eight-armed Brahmā were without attributes and showed a mudrā, while the others had on the right a lotus bud and a handle, and on the left a small flower pot. It is clear that the express purpose was to give Brahmā completely different appearances.

In the Vișnu temple the large image, like the main statues in the other temples in this row, is standing and has four arms; there has been relatively little damage. The front right hand rests on a club beside the god; in the palm of the left hand is visible a triangular object with its point facing downwards. The attributes in the rear hands are the flaming discus in the right and the winged shell in the left. The statues against the rear wall all measure about $1.20 \mathrm{~m}$. The central one represents the god in his two-armed form; in his right hand he holds up a shell, while on his left arm sits a small four-armed Laksmĩ adorned with a separate

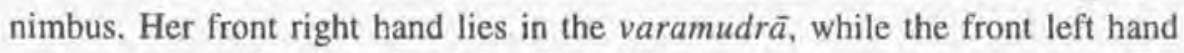
holds a lotus bud against her body; the right rear hand grasps a rosary and the left carries a banner. This statue is now in Batavia [Jakarta] and the other two were in Yogyakarta, but have since been returned to their proper place. On the right side of the central statue is a Vãmanāvatãra; who holds his right leg straight up in the air, prepared to take decisive steps, and he has his right arm in front of his chest, while his left hand rests on a club. The third small statue is a Narasińha, recognizable by its lion's head with flowing mane, which holds the recumbent body of Hiranyakasipu against his right thigh and arm, while tearing open the latter's belly with his left claw so that the intestines are exposed to view.

The main statue in the Nandi temple is a representation more than $2 \mathrm{~m}$ long of Śiva's mount. The bull with a hump on its back lies with its right foreleg folded in front of its body; and its tail, which is curled around its body to the left, is wrapped around a stone slab; its horns have been lost. The Nandi is 
undecorated; it is located directly in front of the Siva statue in the opposite temple, which is clearly visible from this vantage point. Against the rear wall are images of Sūrya and Candra, both on lotus cushions, which rest on a wagon drawn by horses. As it should be, the team of the sun god consists of seven horses, and that of the moon god of ten. The images themselves rise about $1 \mathrm{~m}$ above the lotus cushions. They are magnificently equipped. Sürya holds a lotus blossom in front of his body with both hands. In his right hand Candra bears the soma plant and in his hand carries a banner. The Śaiva character of the latter is highlighted by his third eye.

In the temple opposite the Vișnu temple [candi B] there was a four-armed statue of Siva in a quite damaged condition, but with the pedestal and the body still present. The head, which is a very finely carved piece with high head-dress, death's head, crescent moon, and third eye, is now in Batavia.

Having already mentioned them incidentally, we shall not concern ourselves with details of the great number of statues and fragments which can be found on the site, most of them separated into sorts. We shall confine ourselves to describing a large, unfinished Brahmā image which was found near the Brahmā temple. As its measurements and attributes correspond with those of the main statue in the temple, the guess made by Jochim that this piece was originally intended for the sanctuary but was rejected for some reason to be replaced by the other seems highly probable.

\section{Literature}

Inventaris no. 1332.

Lons (1773) in Leemans, Bijdr. Kon. Inst. 3 (1885); Mackenzie, Narrative of a Journey to examine the remains of an ancient city and temples at Brambana in Java, Verhand. Bat, Gen. 7 (1814) p. 2-9; Raffles, History of Java (1817) II, p. 11-15; Crawfurd, Asiatic Researches 13 (1820) p. 337-368; Brumund, Indiana I (1853) p. 51-66; Hoepermans, Hindoe-oudheden van Java (18641867), Rapp. Oudh. Dienst 1913 p. 241-252; Groeneveldt, Catalogus Batavia (1887) no. 783 a-d; Izerman, Beschrijving der oudheden nabij de grens der residentie's Soerakarta en Djogdjakarta (1891) p. 38-73; Groneman, Tjandi Parambanan op Midden-Java, na de ontgraving (1893) met lichtdrukken van Cephas; Von Saher, De versierende kunsten in Nederlandsch Oost-Indie (1900) p. 37-66; Van Erp, Verslag betreffende de herstelling der nevencella's van den Hoofdtempel van Prambanan (1903, unpublished); Brandes in Rapp. 1903 p. 63sq.; Brandes, De waarde van Tjandi Prambanan tegenover de andere oudheden van Java, en een hartig woordje over de deblayeering. Tijdschr, Bat. 
Gen. 47 (1904) p. 414-432; Tonnet, De godenbeelden aan den buitenmuur van den Çiwa-tempel te $\mathrm{Tj}$. Prambanan en de vermoedelijke leeftijd van die tempelgroep. Bijdr. Kon. Inst. 7:VI (1908) p. 128-149; Van Erp in Twentieth Century Impressions of Netherlands India (1909) p. 169-171; Knebel, Inventarisatie der Hindoe-oudheden in de vlakten van Prambanan en Sårågedoeg, Rapp. 1909 p. 54-120 en platen 117-136; Van Erp, Vondst van een merkwaardigen Garuda in de Prambanan-vlakte, Rapp. 1911 p. $74-76$ en plaat 180; Jochim, Prambanan en omliggende tempels, Tijdschr. Bat. Gen. 54 (1913) p. 471-498; Rouffaer, Oudheidkundige opmerkingen, Bijdr. Kon. Inst. 74 (1918) p. 151-163; Van Stein Callenfels in Lulius van Goor, Korte gids voor de tempelbouwvallen in Prambanan-vlakte (1919), p. 32-42; With, Java (1920), especially p. 68sq.; Vogel, Het eerste Răma-relief van Prambanan, Bijdr. Kon. Inst. 77 (1921), p. 202-215; restoration reports, especially Oudh. Verslag 1919, 4. p. 130-136, 1920, 2, p. 46sq.; 4, p. 112 sq. 


\section{The god Brahmā surrounded by mahaṛ̦i}

The following note by Bosch, which is probably only known to a handful of Dutch archaeologists, was printed in Dutch in one of the older reports of the Netherlands East Indies Archaeological Service. Hopefully, this English translation will rescue it from its former obscurity. It is moreover to be hoped that in its demonstration of the relevance of Puranic texts for the explanation of the reliefs studied by Bosch, this note will stimulate similar research on the as yet unidentified Krsșna reliefs of the Vișnu temple, as well as the reliefs on the two so-called 'court temples' (candi apit)."

As we know, both the recessed and the raised wall surfaces of the body of the Brahmā temple at Prambanan contain carvings, at the level of the ambulatory passageway, of seated figures which can be identified by their venerable appearance, their long pointed beards and their jațämakuța as rșii. The images show little variation. The gestures of the hands suggest the giving of instruction. Sometimes the right hand is holding a fly swatter, while the left hand is resting in the lap or on the knee. Behind the right shoulder is depicted a trident pointing upward, with a water pitcher suspended from it. Across the left shoulder there is a cammara, except where this is held in the hand, with the handle hanging in front. On either side of the seated central figure there stands a rssi or apprentice rși, likewise with a long pointed beard and a jațāmakuta.

Are these groups of maharsi, 27 in all, intended purely as ornamentation of the shrine, or do they represent particular figures who may be identified by name? Professor Krom, pointing to the figures in the corresponding places on the Śiva and Vișnu temples, which all possess a special significance, tends to the view that the latter supposition deserves recommendation.!

That he is most probably right is evident from a passage in the Vișnu Purāna ${ }^{2}$ to which I wish to draw attention here. In this passage the sage Parāsara asserts in reply to a question by Maitreya that each Dvâpara era the god Vișnu, in the form of a Vyãsa (editor), divides the Veda, which by origin is unitary and indivisible, into many parts in order to promote the well-being of mankind. That

- Excerpt from the epigraphic and iconographic notes in the Oudheidkundig Verslag 1922, tweede en derde kwartaal, pp. 66-7. Translation by Ria van Yperen.

1 N.J. Krom, Inleiding tot de Hindoe-Javaansche kunst, 1920, 1:369.

2 H.H. Wilson, The Vishṇu Purâna, 1840:272. 


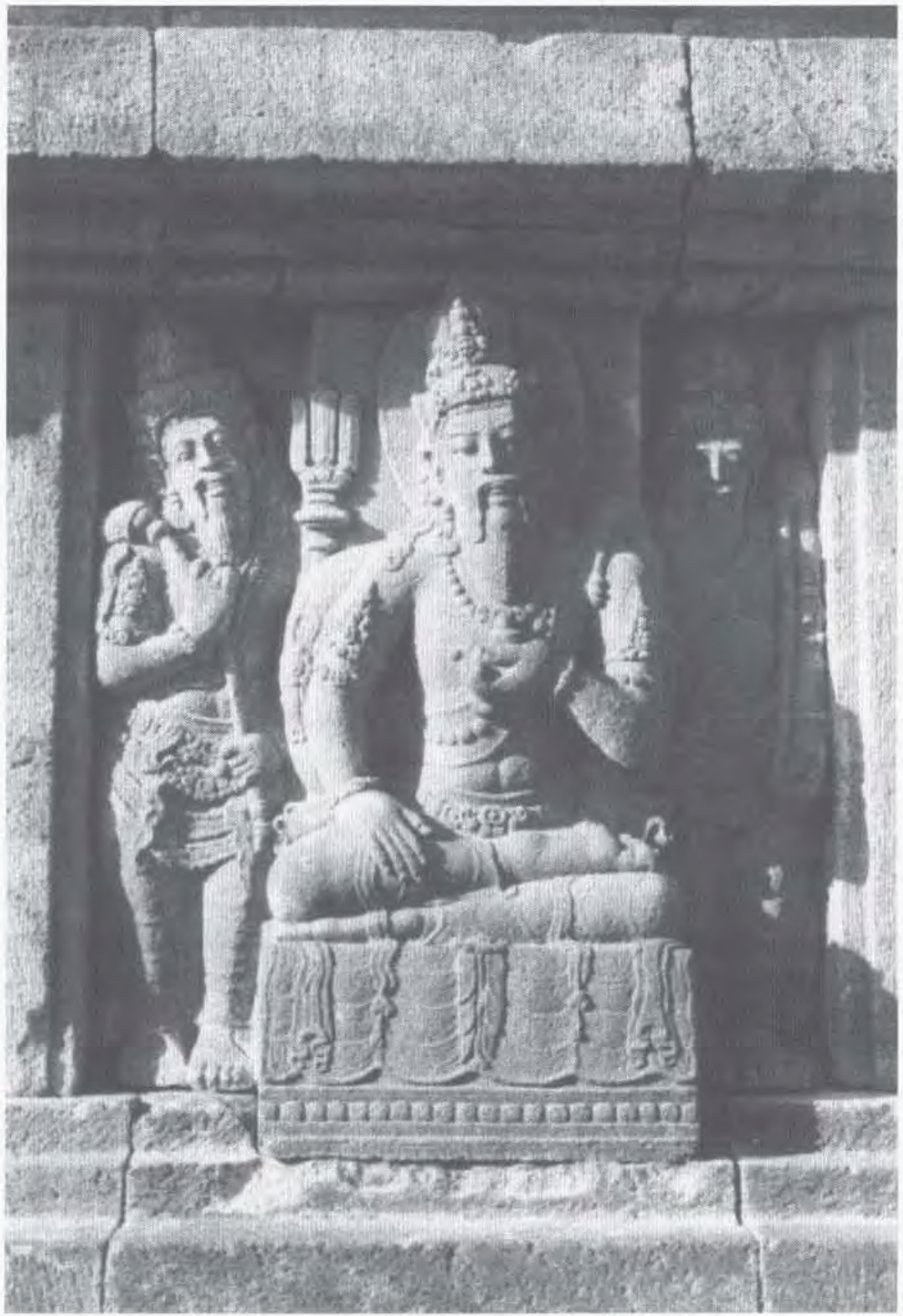

Photo 11. Maharși relief on the Brahmā temple (photograph Roy E. Jordaan) 
is to say, he makes the Veda fourfold taking the limited devotion, inner strength and assiduity of mortals into consideration. The material form he assumes to effect this division is known by the name 'Veda editor' (Veda-vyâsa). The Vedas in the Vaivasvata Manvantara have been rearranged twenty-eight times by great Rși in the Dvāpara era, while twenty-eight Vyāsas who divided the Veda into four have passed in succession.

The first of the maharssi to have been a Veda editor appears to have been Brahmã in person. He was followed by Prajāpati (Manu), Uśanas, Bṛhaspati, Savitri, Mṛtyu, and so on, with Kṛșna Dvaipāyana coming last.

The number 28 of the Veda-vyāsa, with the god Brahmā himself as the first and foremost, corresponds with that of the maharssi images in the Brahmã temple, including the main image in the inner sanctum. We may assume that this is no coincidence and that it was the intention of the sculptor of the Brahman temple to depict Brahmã in his capacity as chief Veda editor among his staff of co-editors, the 27 maharși. This now enables us to name each of the latter, if we feel so inclined, beginning with Prajāpati to the left of the entrance, continuing along the pradakșiṇa and the Vișṇu Purāṇa list, and ending with Kṛșna Dvaipãyana to the right of the entrance. 
-978-90- $04-26042-9$

Downloaded from Brill.com๑4/26/2023 02: ०3:20PM via free access 


\section{B. DE HAAN \\ Candi A and candi B}

Like Bosch's note reproduced above, the following note by De Haan has remained obscure, especially among non-Dutch archaeologists, as is evident from their persistent use of the misnomer 'văhana temples'. It was decided to include this note in translation not only on account of its rectification of this error but also in recognition of De Haan's scholarly contribution as an architect, who sadly died too young. His note points indirectly to a number of interesting systematic differences in the construction and ornamentation of the temples in the central temple area which might be fruitfully explored and investigated further."

Up until now the three eastern shrines on the upper terrace have been called more than once 'vâhana temples'. Coming from the south, we would therefore come across the Hamsa, the Nandi, and the Garuda shrine in that order. If it were certain that they were vāhana temples, then the names 'Hamsa' and so on would in fact be correct. I have grave doubts as to whether they were actually 'vāhana' temples, however. The view that they were is based on the circumstance that there has of old been a Nandi in the middle temple, and there is no reason whatsoever for doubting that this really belongs here. The situation is different as regards the so-called 'Garuda' shrine, however. IJzerman was convinced that there was originally a statue of Siva inside this temple. We thus find the following passage in his description: 'This temple once contained the Siva statue of which the head and the mutilated body were recovered from among the rubble:! We moreover know that the Garuda which is located in this temple at present was only installed here later. So we may justifiably doubt whether it has always been here from the beginning.

In this connection it may be useful to point to a curious phenomenon, which may induce the specialist to try and establish greater clarity in the abovementioned matter of the three eastern shrines at Prambanan. What I have in mind here is the typical layout of the various Śaiva temples, which in my view reflects a regular system that encompasses simple temples as well as the most complicated temple complexes. The simple, non-composite temple is to be taken

- Excerpt from Oudheidkundig Verslag, eerste en tweede kwartaal 1927, pp. 14-7. Translation by Ria van Yperen.

I See Uzerman 1891:57. 
as nucleus and point of departure here. This is logical, as this sort of shrine itself constitutes a complete temple that embodies the very quintessence of the religion, as it were. We find the following arrangement here:

$\begin{array}{ccc} & \text { Śiva } & \\ \text { or } & & \\ \text { Durgā } & \text { Linga }\end{array}$

\section{Ganeśa}

Before it will be possible for me to outline the layout of the second type of sanctum, namely the smaller temple complex, it will be necessary to make a slight detour, as so far the objects of worship of none of the temples of this type have been retrieved in a complete state.

The temples referred to by the term 'smaller complexes' include Badut, Merak, Ijo, and Sumbernanas (Candi Sumbernanas will not be included in the further discussion, however, as unfortunately it is not relevant to our investigation). All of these temples consist of a main temple and three smaller subsidiary temples facing the principal temple. In the smaller subsidiary temples the following arrangement is found 3 :

$\begin{array}{llll}\text { Left } & \text { Centre } & \text { Right } & \\ \text { Badut: } & \text { Linga } & \text { Nandi } & ? \\ \text { B. Gono: } & ? & \text { Nandi } & \text { Mahāyogi(? })^{4} \\ \text { Idjo: } & \text { Linga } & \text { Nandi } & ?\end{array}$

If one combines these data for the subsidiary temples, one arrives at the following arrangement for the smaller temple complexes:

$\begin{array}{lll}\text { Linga } & \text { Nandi } & \text { Mahāyogi } \\ \text { Guru } & \text { Linga } & \text { Durgāa } \\ & \text { Gaṇeśa } & \end{array}$

I wish to point out here that in Candi Badut five of the said seven objects are present. Only Ganeśa and Mahāyogi are missing. Of Prambanan, the most complete Śaiva sanctuary we know in Java, the following plan may be drawn:

2 I shall not discuss the Kãla and Nandiśvara which belong to this any further here, as they will not be of any further relevance. [Editor's note: for Guru read Agastya.]

3 The situation is described from the point of view of someone standing with his or her back to the main shrine and facing the smaller subsidiary shrines.

4 The statue of Merak has not yet been definitely identified. It consists of the figure of a seated man in the well-known posture of Guru [Agastya] with two kneeling worshippers. 


Vịnnu Durgāiva Guru Brahmā
Gañeśa

What strikes one immediately here is that this largest temple of all comprises the same elements in exactly the same arrangement as the smaller types. Here, too, the simple temple constitutes the nucleus and key element of the plan, while in combination with the three eastern temples it displays the arrangement of the smaller complexes. Proceeding outward from the simple shrine, one finds an increasingly complex evolution governed by fixed laws, in agreement with the strict framework of rules and regulations to which architects and builders of the Central Javanese period were subject in other matters as well. As far as that goes it is inconceivable anyway, considering the extreme unity marking Central Javanese art as a whole, that there would have been even the slightest hint of arbitrariness with respect to an important matter like the layout.

If the supposition of the systematic development of the arrangement outlined above is indeed correct, we may suppose the southern shrine of the eastern row. which at present is empty, to have therefore contained a Mahãyogi.

It may perhaps seem as though this analysis of the layout makes the Brahman and Vișnu shrines look rather isolated from the rest, instead of forming an important part of the whole, as their architectural design beyond any doubt shows them to do. In this connection the fact that Śiva here is honoured as the supreme god should be taken into consideration, however. As a result, the dedication of the three eastern temples as well as the principal temple to him will no longer come as a surprise. On the contrary, this seems to be an apt way of giving visible expression to the idea that, as the Mahãdeva, he towers high above the other gods of the trio.

The question is whether we may perhaps note any features of the temples themselves that support this view. Although this question is rather premature, as the examination of the eastern temples is still in the initial stages, I am able to draw attention to a few curious details.

In the first place, we may note that the decorated supporting ledge of the capital of the first base displays the same motif as the corresponding ledge of the Siva temple, whereas those of the Brahmā, the Vișnu, and the small 'court temples' [candi apit] display a different type altogether. On the Siva and the three eastern temples we find a garland with a rosette, while on the Brahmā and the other temples the rosette has been replaced with a parrot. A similar correspondence is found in the capitals of the pilasters of the first series of 
shrines A and B with the pilasters of the first series of niches of the principal temple. These may be minor details, but they are none the less striking for all that. Later research will have to establish whether there are more or perhaps even more obvious correspondences. One further feature I should point out is that the socle of temple A (which I regard as a Mahāyogi shrine) was adorned with two series of sculptures placed one above the other, which in combination display the ornamental motif 35 times.

All this has prompted me to provisionally give the southern and northern temples of the eastern series the more neutral labels A and B respectively.

[Editor's note: De Haan's statement that Candi Prambanan comprises the same elements in exactly the same arrangement as the smaller types elsewhere is not quite accurate. The elements are the same but not their arrangement, as is clear from the reversed positioning of Durgā and Agastya. As was pointed out by IJzerman (1887:268, 1891:50), the different arrangement may be related to the different orientation of the Loro Jonggrang temple complex: facing the east instead of the west. Considering the strictly systematized character of the design, one could argue that as a consequence of this Candi A must have contained a linga rather than a statue of Mahãyogi as was posited by De Haan, and Candi B a statue of Śiva Mahãyogi. Candi B, it will be remembered, in fact contained a statue of Śiva, though not in the guise of a yogi, which leads us to question the meaning of the designation Mahãyogi. Judging by his note 4, De Haan seems to identify Mahāyogi with Guru, who, as Poerbatjaraka (1924) had demonstrated, actually represents the saint Agastya. These things aside, one also has to take into account the statue on top of the Kăla head over the entrance to the chamber of Śiva Mahādeva, which still needs to be identified (see Part One, section 6).] 


\title{
W.F.STUTTERHEIM
}

\section{The arrangement of the Rāma reliefs of Candi Loro Jonggrang and the course of the sun}

\begin{abstract}
Although Stutterheim's hypothesis about the correspondences between the course of the sun and the life of Rāma as unfolded in the Prambanan reliefs put forward in the article below is quite plausible, a close examination of his arguments will reveal all kinds of problems that still need clearing up - something of which the author himself was well aware. It is precisely because of the provocative character of the questions asked and comments made by Stutterheim that the essay has been chosen for inclusion in translation in this volume. Aside from presenting the findings of specialized research into the way in which the solar cycle is represented in all kinds of details of the panels at Prambanan and bringing this into relation with Indian astronomical ideas, Stutterheim points to some interesting religious aspects of the proposed sun symbolism. He suggests West and East India as possible areas of origin of sunworship cults that are thought to have also attracted followers in ancient Java and Bali. His suggestion that the design of the Loro Jonggrang temple complex can be quite well explained in Tantric Buddhist terms and that, for example, the Śiva-Brahmā-Vișnu trio might be regarded as an emanation of Vairocana, 'the dhyannibuddha with the markedly solar character', is also intriguing. These suggestions seem to vindicate our plea for reopening of the investigation into Prambanan's Buddhist background, whereby the complicated symbolic relationship between Candi Loro Jonggrang and Candi Sewu (where Vairocana was installed as the main deity at a certain moment) might also be unravelled:
\end{abstract}

That we know only too little about the true significance of Old Javanese ruins, about their meaning to the people who built and used them and about their function in day-to-day life is a truism that cannot be too often repeated. All the inferences drawn about this on the basis of more or less intellectualistic syllogisms, and all the 'explanations' of figures of gods and heroes and their disposition on the relevant temple - in a word, of what they meant to the people of the period - accumulated and recorded with so much diligence and assiduity by us archaeologists would all draw at most a compassionate smile or shrug of the

- First published as 'De plaatsing der Rāma-reliefs van tjandi Lara-Djonggrang en de zonne-omloop', Bijdragen tot de Taal- Land-en Volkenkunde 84 (1928), pp. II8-3I. Translation by Ria van Yperen. 
shoulders about so much ignorance and lack of insight from the Old Javanese priests if they could be aware of it. Our analyses remain hopelessly superficial. This is doubtless why the ancient religion of Java tends sometimes to be represented as a meaningless labyrinth, inspired and sanctioned by tradition, in which the priests themselves lost their way and which offered ample scope for deviation from the straight and narrow path of orthodoxy. We are regularly confronted with what we feel should be regarded as deviations from the logical system of our reconstructing. We then immediately jump to the conclusion that the sculptor must have made a mistake, especially in the case of images of deities or series of scenes, so that at least the reputation of the priest remains unmarred. I have nonetheless often had occasion to rectify such a conclusion and show that the error probably lay with us archaeologists rather than with the sculptor and that there definitely was a logical explanation for the presumed illogicality, but that this explanation accorded with a different conceptual system, which was unknown or only partially known to us. As W.H. Rassers [1922] has pointed out especially in his Panji study, the lack of a proper understanding of this conceptual system, of this way of imagining the world, which was so radically different from our own, cannot but give rise to errors of interpretation of the relevant figures and their actions. Indeed, one may generalize that the better one is able to penetrate this conceptual world, the better an understanding one will have. As far as the relics of ancient Java are concerned, it has been primarily the representations in reliefs which have regularly reduced the analyst to despair, as often the arrangement of the subjects treated seemed to lack logic and we seemed to be confronted with an apparently wholly random disposition of scenes over the available spaces.

The fact that these reliefs were carved into the holiest of holy edifices of the period should of course in itself be a caution to exercise particular care and resignation where the actual disposition does not entirely meet our expectations. Such is in fact the case with the scenes in the reliefs of Candi Loro Jonggrang, near Prambanan. Their interpretation is especially fraught with difficulties. To begin with, we find the story of Răma distributed over two of the three temples located here, namely the Śiva and the Brahmā temple, while actually we would have expected the Vișnu temple to be a pre-eminently suitable candidate for adornment with stories of the Vișnu avatāra Rāma. By the same token we would have expected to find tales of Śiva depicted on the Siva temple, whereas the first figures to be noted in the reliefs adorning this temple are those of Garuda and the second Viṣnu himself! The conclusion that forces itself upon us is that the priests giving instructions for this unusual arrangement at the time these temples were designed either were no longer experts in their profession or took considerable liberties. 
Another feature we find unsettling is the distribution of the episodes. To some too much space seems to be devoted, to others too little or none at all. A few have even been interpreted as 'erroneous' and improved on by the analyst. Here a male figure ought to have been a female one; there too many figures were placed together in the one scene and there seemed to be two Rãmas, two Lakșmanas, and so on, wandering through the forest; and numerous incongruities on minor, incomprehensible points were set right in passing.

I myself have had the opportunity to check some of these sculptor's 'errors' against a few popular Malay and Javanese tales and stories, and so to discover these to be mistakes on the part of the archaeologist concerned.' It furthermore became apparent to me that what we have here is not the story as related in the official poem of Răma by the great poet Vălmīki, which has invariably been regarded as the original from which the numerous variant Rāma stories throughout India derived, but some official form of such a Rāma tale that probably only corresponded roughly to the great work of the court poet. It is even likely that such variant versions are closer in content to the archetypal Rāma story than the latter. Unfortunately I did not succeed in tracing the origin of these variant versions, although I did have reason to believe that western India played an especially important role in the diffusion of such stories across the Archipelago. This has nevertheless put the problem of the origin of the Hindu culture in the Archipelago in a new phase, where every clue, no matter how trivial, must be re-evaluated in the light of this new orientation, whereby our gaze is no longer restricted exclusively to southern India, which did not experience any kind of flowering until much later, but must be directed to the west, and possibly also to the east, as areas from which the major influences which reached beyond India in the first millennium of the Christian era emanated. These clues include the phenomena I wish to discuss below.

The series of relief panels that are carved on the inside face of the parapet along the passageway of the Siva temple at Prambanan and which, thanks to some minor repairs, can now be viewed in the proper light conditions, is naturally divided into four equal or near-equal sections by the four flights of steps and porches. ${ }^{2}$ Following the interpretations of the individual scenes which $I$ have proposed earlier, we note that the first quarter of the series covers the scenes from the descent of Vișnu up to and including the return of Râma to Ayodhyāa ; the second quarter the episodes from the coronation of Bharata up to and

Stutterheim, 1925. Râma-Legenden und Rãma-Reliefs in Indonesien, München.

Krom, 1923, Inleiding tot de Hindoe-Javaansche Kunst I, pp. 453 ff.

3 Stutterheim 1925, Räma-Legenden II, plates 2-16; for the interpretation see I, pp. 148151. 
including the encounter with Śürpanakhāä; the third the episodes from Rāvaṇa's rape of Sitā up to and including the victory over Bālins; and the last the deliberations about the search for the abducted bride up to and including the crossing. ${ }^{6}$

On the face of it, there is no special system to be discerned in this disposition, while in some cases, for example that of the rape of Sita, the scenes of the golden hind and of the rape itself, which seem to us to be closely interconnected, are rudely interrupted by the stairs. In reality there is a definite system to be detected in the arrangement of the four series across the four quarters of the temple, however. It is striking how Rāma meets with a chain of adversities from the moment of his return to his palace to his combat with Bâlin. The entire history of the exile and the rape of his spouse falls between these two points. All the events depicted on the opposite half of the temple, on the other hand, are of a more positive and more pleasant nature for Rāma; from the beginning to the return they constitute a series of major and minor successes (his selection from among his brothers by Viśvamitra, the conquest of various demons, the acquisition of his bride, and, last but not least, the conquest of his most dangerous adversary, who bears the same name as he, Rāmaparaśu). The last quarter series then marks the beginning of another chain of successes, with as ultimate objective the recovery of his bride. If Bālin had not been defeated, then Surgriva would never have been able to ascend the throne, and Hanumat would never have been dispatched and, as a consequence, Sitã discovered. Hence the four points at which the series is interrupted by the stairs appear to have been of the utmost importance for Rãma, namely, following the pradakșināa, his birth, the zenith of his success, his exile, the rape of his bride, his combat with his dangerous opponent Bālin, his receiving assistance, and the crossing to Lankā. Taking a closer look at these salient points, we are able to divide them again into two sub-categories, namely, in the first place, transition points, and in the second place, turning-points. The birth and rape can be assigned to the first category (the birth being an avatāra of Vișnu, hence no more than a transition to a new phase), while the return and the victory over Bālin are turning-points at which success changes to adversity and adversity to success respectively.

We can accentuate this division of the narrative material more strongly by considering the location of the salient points that play a role here. The birth is

4 Stutterheim 1925, Rāma-Legenden II, plates 17-33; for the interpretation see I, pp. 152-161.

5. Stutterheim 1925, Räma-Legenden II. plates 34-51; for the interpretation see 1. pp. 161-169.

6 Stutterheim 1925, Räma-Legenden II, plates 52-65; for the interpretation see I. pp. 170-173. 
located in the east, the zenith in the south, the rape and the first appearance of arch-enemy Rãvana in the west, and the beginning of a new rise in the north. Taking the nature of these points into consideration, it does not seem to me too wild a supposition that the transition and turning-points in Rãma's career as depicted on the Siva temple are associated with the corresponding points in the course of the sun. It is surely not accidental that Rãma's rise, decline, and second rise coincide with the rise, decline, and rise of the sun in its daily course, if we speak of the eastern, southern, western, and northern points in that order, or in its annual course, taking the labels spring, summer, autumn, and winter points to be appropriate. The Rāma sun rises in its course from the eastern point until it reaches its zenith at the southern point.? Then it descends from its solar house (the southern point $=$ Ayodhya $\bar{a}$ ), although it is still strong, to set - that is to say, to start its combat with the demons of the underworld, which have robbed it of its radiance (Sitā) - at the western point. ${ }^{8}$ It reaches its nadir in the north, where the last enemy (Bālin) is defeated, but where at the same time it commences its new ascent. It finally reaches the opposite shore with the assistance of good powers from the underworld, and so the new day begins (in Lankā)."

Here the first diurnal course of the Rāma sun ends and a new one begins. This I will not portray to my readers, as the arrangement of the reliefs on the Brahmā temple is uncertain and still leaves too much room for doubt. ${ }^{10}$ So for the time being we had better restrict ourselves to the Siva temple.

7 The series opens with the Garuda sun bird.

* In this quarter the redemption scenes are worth noting (Stutterheim 1925, RãmaLegenden II, plates 36 and 37), as in the old system the setting sun, on its passage through the underworld, could in effect assume the role of saviour of the souls pining here, which, with its help, might have an opportunity of reaching the upper world with it (compare Egypt). Interpretations like this of course have no connection with the systematic distribution of the reliefs, but only with the possible solar character of the story of Râma, between which two things we should distinguish clearly.

9. It seems likely to me that the obvious demonic character of the monkey figures, which was to become especially conspicuous in later times, is interpretable as a chthonic trait. The räkşasa are certainly no underworld forces, their lord, Rāvana, seeming rather to be Rāma's opposite, who rises at the latter's fall (extreme westem end of the Śiva temple) and falls at his rise. So could he be a lunar figure? This is in contradiction with the demon's whole character, however. The answers to these questions, if they can ever be given, will help greatly to solve the question as to the extent to which the solar system as a mythical legend was experienced and assimilated by people in real life. Unfortunately the state of disrepair of the Brahmã temple will be an obstacle in this.

$10 \mathrm{Mr}$. De Haan, who is at present engaged in attempts at assigning loose relief panels of the Brahmã temple a place using mainly architectural clues (mouldings, architraves, rabbets), has arrived at the following sequence: the departure of the troops up to and including the fight between Rāma and Indrajit from east to south; the episodes of Kumbhakarna up to and including the reunion between Rāma and Sitã from south to west; 
It will not have escaped the attentive reader's notice that the application of this solar imagery to the sequence of episodes in the reliefs is attended with a number of problems of apparent incongruity with some of the facts. For instance, one would expect everything to the east of the southern point to testify to a regular, uninterrupted ascent. Nevertheless, immediately before this turningpoint there is a scene, namely that of Kaikeyî's intrigues, which on the contrary is rather ominous. As is well known, there used to be some uncertainty about the identification of this scene, so that we may assume that the correct interpretation of it still remains to be given. ${ }^{11}$ In this connection I would point out, however, that the circumstance that such a scene or series of scenes immediately before the transition to a new quarter series has apparent links as it were with the next quarter series is a regularly observable phenomenon. In the west the episode of the golden hind foreshadows the rape, which does not occur until after the transition. In the south Surgriva's restoration to the throne of the land of the monkeys occurs before the transition to the east. In the east, finally, the sculptor, quite contrary to what we would have expected, has portrayed a bit of Lankā at the very end, where we would have reserved this for the Brahmā temple.

So this peculiar feature is found regularly and apparently is part and parcel of the system used, so that we may safely assume that our interpretation of the Kaikeyi scene is, in fact, correct. What we have here is probably the practice, still found in Java today, of never letting transitions in stories and similar matters take place suddenly and unexpectedly.12

A question prompted by this apparently different perspective on the distribution of the Rāma story over the temple building is whether there is any regularity to

the banishment up to and including Sitā's sojourn with VāImiki from west to north; and the end of the story from north to east.

It will be noticed that the climax (Rãvana's defeat and reunion with Sitã) here is located in the west, which is seemingly incongruous with the observations about the Siva temple in the body of this article. In view of the subdivisions described further down in this article, this need not necessarily be the interpretation to be given of this, however. 1 shall return to this point later.

it Stutterheim 1925, Rāma-Legenden I, p. 151; cf. II, plate 16.

12 Compare the practice of alluding to the next canto in the final passages of the preceding one. This practice, aimed at avoiding sharp contrasts and sudden changes as much as possible, is not exclusively Javanese, in fact, but should be considered typical of every non-modern conceptual system, being the more prominent in accordance as the vestiges of a system encompassing the whole of social and private life are more or less clearly discernible. In some cases (certainly including the Javanese one) this attitude has been carried to an extreme point, so that its identification is one of the principal preconditions for a proper understanding of the relevant society. 
be discerned in the distribution of the individual panels. I believe this question can be answered in the affirmative.

As we know, each quarter of the series as a whole is divided into six panels, making 24 panels in all. Provisionally assuming that it is the annual course of the sun that is symbolized here, the conclusion seems warranted, to my mind, that each panel represents a one-twentyfourth part of that course. This then is half a month, or, more accurately, a pakșa, seeing that not exclusively whole months so much as paksa were used as chronological units. Unfortunately I have not been able to discover any further division into sukla and krșna pakșa in this connection, although this is sometimes definitely the case. We are impeded here by our imperfect knowledge of the values assigned to such a division of months in a cosmic context, however, so that we will be inclined to classify as śukla something that a Hindu Javanese would have considered to be krșna. ${ }^{13}$

Perhaps it will be possible, on the other hand, to carry the division a step further and find evidence of the use of a particular system in the distribution of the scenes, which is so entirely different from that of the panels. Although I am not able to give a definite answer to this question, either, I would point to the curious fact that the panels of each temple half can be divided into 30 scenes, which makes 60 scenes for the temple as a whole - corresponding exactly to the number of nādi of the diurnal solar chronology!14 This division is not yet absolutely certain, however, since my attempts at separating the different scenes off from each other have sometimes shown plainly that there still remains a

13 The above observation that the possible discovery of traces of a zodiacal treatment in the various panels, for example, will have certain implications not so much for the temple as for the story is true here, too. It may at most have some connection with the adaptation of the story of Rāma to the temple. In this context it will be feasible to divide the relief panels into matched pairs, although this gives rise to occasional problems.

14 In connection with the division into thirty scenes posited by $\mathrm{Mr}$. De Haan in his attempts at reconstructing the sequence of the reliefs of the Brahma temple, I must remind the reader here of the curious fact of the Jocation of the climax on the western face of this temple indicated in the above note. Where the reliefs of the Siva temple can be divided into sixty scenes, over against those of the Brahmâ temple into only thirty (with 24 panels being preserved), we may suppose the circumference of the Brahmã temple to be half that of the Siva temple. This would entail a shift in alignment with the points of the compass, however, the Brahma temple thus coming to represent only half a day. Perhaps the other half was provided by the Visnu temple. The complex as a whole would then constitute a two-day lakon, with two consecutive avatâras. This division would also explain why the boundary between the series on the southern corner is so much less distinct in the Brahmã temple than in the Siva one, the climax of the story still being far off at this point, so that a smooth transition to the remainder of the east-south passageway is essential. Meanwhile it should be observed that a boundary of sorts in the arrangement of the panels is necessary. And there is such a boundary, in fact, but it is not provided by including a stair-portal but only an ornamental panel in the series. 
certain margin of error here and there, which margin nevertheless is by no means so great as to produce a significant change in the total number. ${ }^{\text {Is }}$

Is Seeing that this division of the scenes is not, like that of the panels, a logical consequence of the architectural layout of the temple, I shall give a brief description of these below. The Roman numerals refer to the relevant panels, the Arabic ones to the scenes.

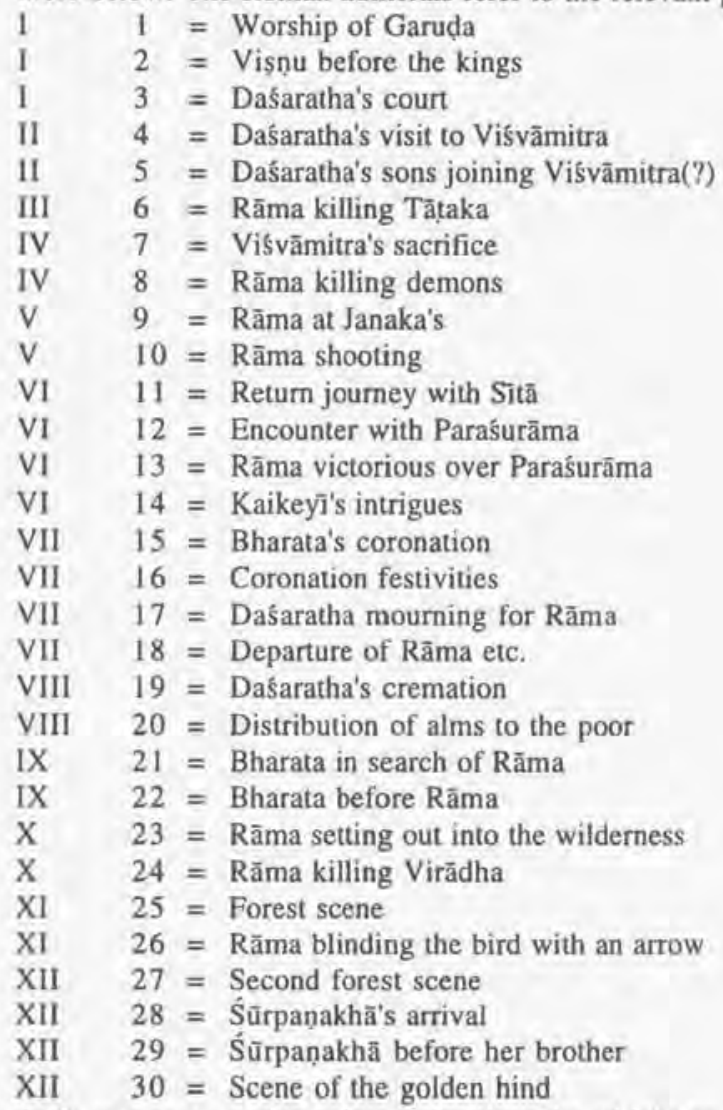

As is apparent, a minor change for the sake of joining two scenes together or dividing one scene into two would seem in place here and there. Where the total is extremely close to the number thirty in whatever way one does this, however, I feel that a division into thirty is not unrealistic. The third and fourth quarter series pose a few more difficulties.

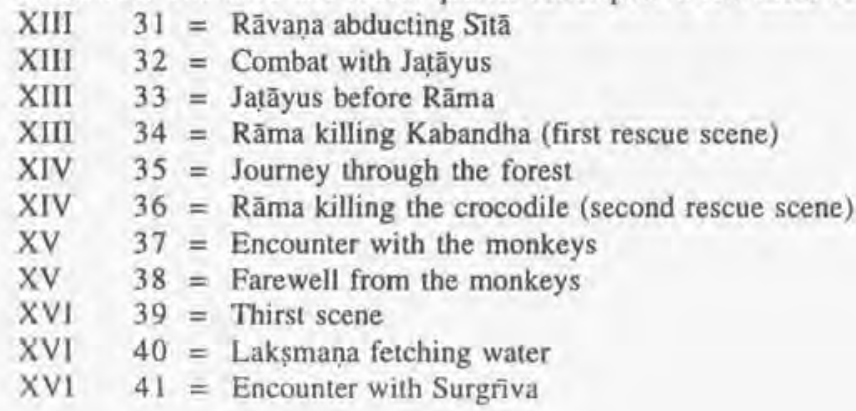


If our assumptions are correct, then the diurnal and the annual course of the sun are worked into the story of Rāma as depicted on this temple (and hence also the two others) side by side and interwoven with each other. Clearly the supposition of this systematic distribution of the narrative material over the available space invalidates many objections that were previously raised against such a distribution. Where previously in our opinion too much of a particular episode had been depicted here and too little of another there, it now seems plausible that the sculptor was influenced by the system in the choices he made, and we will certainly expect no deviations from this system from him. It is equally clear, however, that we have here something which on the one hand has close links with present-day wayang performances and on the other hand deviates from these considerably. As far as the former point is concerned, our findings may corroborate Brandes' observations on the East Javanese character of Candi Loro Jonggrang to an important extent. ${ }^{16}$ What we have before us here, in fact, in a sense is nothing other than a two-(three-)day wayang performance, whereby the content of the story enacted in a like way is meant to evoke different moods among the audience as time progresses. This mood is

\footnotetext{
XVII $42=$ Trial of strength

XVIII $43=$ First combat with Bālin

XVIII $44=$ Second combat with Bālin

XVIII $45=$ Surgriva's restoration to the throne

XVIII $46=$ The monkeys celebrating (banyolan?)

XIX $47=$ Journey to the coast

XIX $48=$ Deliberations

XIX $49=$ The troops receiving instructions to march

XIX $\quad 50=$ Monkey scene (banyolan?)

$\mathrm{XX} \quad S \mathrm{I}=$ Hanumat in Lañkā

XX $\quad 52=$ Hanumat finds Sitā

$\mathrm{XXI} \quad 53=$ Hanumat's tail set on fire

XXI $\quad 54=$ Hanumat setting fire to Lanka with his tail

XXII $55=$ Hanumat reporting to Răma

XXIII $56=$ Rãma forcing the sea god to come

XXIII $57=$ The sea god appearing

XXIV $58=$ The building of the dam

XXIV $59=$ The destruction of the dam by fish

XXIV $60=$ The crossing

Meanwhile it should be noted that the division suggested above gives rise to a certain irregularity, resulting in twice 14 scenes for the eastern half of the temple, and twice 16 for the western half. If one were able to arrive at a series of 15 scenes for each half, there would be perfect equality. In view of the uncertainty surrounding the entire question, it is important to exercise caution here, however, as such a division into unequal halves may be inherent in the system.
}

16 TBG XLVII: $414 \mathrm{ff}$. 
joyful from early morning till noon, anxious till sundown, sad till midnight ${ }^{17}$ and hopeful again till dawn, whereupon this hopeful mood will probably change to the joyful one of the beginning of the first day in the course of the performance on the second day.

As regards the second point, it must be said that there are also major differences with the structure of the lakon observable. The main difference is that the hero of the story depicted on the temple obviously is not a moon hero, as demonstrated for Indonesia by Rassers, but a sun hero. This is a difference between Central and East Java that corresponds with many other differences between the artistic conceptions of these two cultural centres to which I have drawn attention elsewhere.

In this latter connection, I would refer back for a moment to the observation at the beginning of this essay that it seems strange to see the story of Rama depicted on the temple of Śiva. However much the discovery of the observance of a strict system in the distribution of the narrative material may reconcile us to various curious features that seemed strange to us at first, it cannot reconcile us to this particular incongruity. It would seem to me, however, that the indiscriminate application to Java of the system of 10 Vișnu avatāras as found in more recent Indian literature is an obstacle to us here. After all, we have reason to believe that the series at the time of Candi Loro Jonggrang was an entirely different one. ${ }^{1 \mathrm{x}}$ And this is intimately bound up with the position occupied by Vișnu himself in the Trimūrti.

17 I would refer in passing to the Rãma gandrung theme that is so prominent in one of these parts of the story in Yasadipura's Sêrat Rāma.

18 Krom (Inleiding etc. 1:97) says about this: "The originally indefinite number of these avatäras was later fixed at ten, the majority of which have also been found in Java'. This indicates that the author expected to find a series of ten in Java, and hence also a Vișnu, in the position of the Supreme God connected with this series in India. In actual fact, only six representations of avatāras have been found in Java so far. They are the Varāha, Nrrsingha, Vāmana, Paraśsurāma, Rāma, and Krșna avatāras. Of the remaining ones, the Matsya, Kurma, Buddha, and Kalkya avatāras, no images that can be identified as such with certainty remain. The key-stone of Candi Sawentar $(O V$ 1922, figure 11) is to be interpreted as a solar representation ([Stutterheim in] Djåwa 1926:338), so that it cannot be a Kalkyavatāra. The so-called 'Churning of the Ocean' as allegedly depicted in the wellknown relief of Sirah Kencong, which might thus indirectly contain a representation of the Kūrmāvatāra, actually is a different scene altogether (Djåwå 1926:336), while of the other two no trace has ever been discovered (cf. Drewes 1925, Drie Javaansche Goeroe's; Hun leven, onderricht en messiasprediking, pp. 153-4).

Analysing the information provided by the remains of Candi Loro Jonggrang concerning the avatära series that was in use there, furthermore, we discover that the temple of Vișnu must have contained four representations of the god: one as Vãmanāvatăra, one as Varāhāvatāra, one as Nrsinghāvatāra, and, in conclusion, the principal statue. Evidence that there were not more manifestations depicted there may be provided by the fact that the 
In areas where the series of avatāras that was reduced to ten in more recent times is prevalent, Vișnu is worshipped as the highest principle and god of the universe, alongside and without any essential connection with the other two deities of the triad. In keeping with what we know from Buddhist texts and present Balinese practice, we may assume that in Java, however, this triad should be regarded rather as a threefold manifestation of an Upper Being, namely the Sun. Where in Bali still today Sũrya is the essence of the cosmos; where Śiva, Vișnu and Brahmã are no more than manifestations of this; where Süryasevana (literally 'Sun worship') is the religious ceremony par excellencely in Bali; where in the Buddhist system of the Sang Hyang Kamahãyanikanwhich undoubtedly was in force in the period of Candi Loro Jonggrang - the connecting link with Saivism is provided by the conception of the triad of deities of that religion (or rather, sect) as an emanation from the dhyānibuddha with the markedly solar character, namely Vairocana ${ }^{20}$; and where, finally, the Central Javanese period must have been considerably influenced by the Sumatran Buddhist doctrines of the Sailendra, whose realm in turn probably came under the influence of that of King Harșavardhana, son of Rājyavardhana, the 'Sun Worshipper' - there such a solar significance as now clearly presents itself to us from the reliefs of Candi Loro Jonggrang should not cause too much surprise. ${ }^{2 !}$

Brahmâ and Śiva temples, too, each contained four representations of the deities to which they were consecrated (Krom 1923, Inleiding 1:482 ff.). In view of the regularity and symmetry which the Candi so clearly evinces, this was only to be expected. Meanwhile I would point out that we only have devotional images of three Vișnu avatãras here, while the three remaining ones of the series in evidence in this Candi are depicted in an entirely different way: Krșna and Rāma admittedly less officially than the three just mentioned, and Parasurăma even significantly less so and as though by coincidence in the story of Răma, None of this points in any way to a series of ten avataras being in use at the time. On the contrary, it suggests rather a series of five, or maximally six, with the last set of three (Parasurāma, Rāma Dāsarathi and Kṛșna) being less important than the first (Varāha-. Vãmana- and Nrsinghāvatăra).

Tracing the development of the avatära doctrine in India, we are struck by the fact that there was originally a much smaller number listed there, with the series comprising exactly the same ones as we have noted for Java (Mahābhārata XII:349, 37). This series was extended later (Hemacandra Raycaudhuri, Materials [...] 1920:105; Bhandarkar, Vaișnavism /.../ 1913:41, 42).

19 See especially Goris $1926: 9 \mathrm{ff}$., and in particular p. 11, where we read: ' [...] the most important and the most often repeated mantra of the whole of the Balinese liturgy, the "Küta mantra", the key formula "Om hrãm hrim sah parămasīwãdityãya namah", Praise to the supreme Śiva Sun'.

20 Kats 1910, appendix I.

21 Stutterheim 1925, 1:211 ff. As regards possible Indian influences, 1 would also point out that among the Saura - a sect which, judging from the inscriptions, must also have existed in Java (Bosch 1920b:510), and who by their name (meaning 'sun worshippers') 
What is more, we may suppose that the choice of precisely this story was determined by the role that was to be played by the ruler whose temple is the subject of discussion here as incarnation of the sun. So it may have been the story of the life of this ruler, as it were, whose magical contact with the living may have been effected by means of this temple, and the story depicted here may have been full of typically Javanese allusions to events in his life. Even if this is true, the key to all this will probably remain hidden to us forever. ${ }^{22}$ Thus the Rāma theme could have played the same role here as the Panji theme in East Java, which became the leitmotiv of historiography. The two themes are related in essence, but differ in their treatment. It is still a common practice among Javanese and Balinese today to adopt a particular wayang figure as leitmotiv

betray the solar character of their views - the sun was worshipped in its daily course as Brahmā at its rise, Śiva at its zenith, and Vișnu at its setting. Răma was their most popular hero (Bhandarkar 1913:152).

There were other sun-worshipping cults besides, however. So the above-mentioned father of Harșavardhana was a follower of a cult which originated from an ancient Persian sunworshipping cult, which was found especially in western India, from Gujarāt to Multân (Bhandarkar 1913:155). This may be especially relevant in connection with the hypothesis of influences via western India (see also Jahn 1908:xx, where he says 'Persian influences are not ruled out'). In this context I would point to my conjecture about Rāma's paternity of Hanumat (Stutterheim 1925, 1:95-6).

Older than these solar cults was that referred to in the Upanisads (Kaușitakibrāhmannopanişad), in which the sun was worshipped with water and flowers in the morning, afternoon, and evening. Especially in Bali, flowers and holy water play an important part in the Sūryasevana ceremony (Bhandarkar 1913:151; De Kat Angelino 1922:passim; Goris 1926:passim).

De Kat Angelino found an invocation to Sũrya and Candra, together with a reference to long life, in a sangupati formula (explained as consisting of the words sangu and pati, meaning 'provisions for death', though it has more likely been derived from Sanskrit samutpatti) in Bali. This is undoubtedly bound up with the Indian custom whereby the guru turns to the sun with a request for a long life for his sișya in the course of the investiture with the cord. The similarity is the more striking when we consider that the sangupati is a formula that is found on the reverse of the panugraha, or diploma for trainee priests on completion of their training (De Kat Angelino 1922:28).

22 The question of whether Candi Loro Jonggrang may have been a funerary shrine has not so far been solved. All I want to note in this connection is that the absence of the ashes of the king buried here need not necessarily be proof to the contrary. Ashes were probably taken to the sea or scattered in a river to be carried to the sea in those times, too. Burial presumably had a different meaning from that in which we take the word, and the use of the word candi/cinandi in Bali indicates that more likely other materials (fluids from the body of the deceased, and so on) were buried in the ground here, over which an edifice was then constructed (Van der Tuuk 1897, I:566). So probably we should think above all in terms of a place of magical contact after the death of the cremated king. I hope to be able to go into this in more detail at some later point. 
for one's life. In Siam this has found official expression in the title Răma for the king; there, too, every king has his own personal Rāma tragedy, ${ }^{23}$

We are digressing from our main theme here, however, at the risk of losing sight of the facts. It will not be possible to construct hypotheses on the basis of the above data until their true value has been tested. It is fairly certain in any case that the distribution of the reliefs on the Candi Loro Jonggrang is not a haphazard one, but on the contrary, is inspired by a strict system - that of the course of the sun. Hopefully other researchers will be in a position on the basis of this to continue the repair work on the cosmic fabric with which the temples of the Central Javanese period must have been overlaid. 
-978-90- $04-26042-9$ 


\title{
V.R. VAN ROMONDT
}

\section{The reconstruction of the Siva temple at Prambanan}

\begin{abstract}
The following contribution by Van Romondt, who as head of the architectural department of the Netherlands Indies Archaeological Service was closely involved in the reconstruction of the Siva temple of Prambanan for two decades, deals inter alia with the question of when the reconstruction of the temple complex was begun, how it was carried out, what official guidelines were followed for this, and what technical difficulties were encountered and how these were solved. Van Romondt's claim that there is no question of actual reconstruction until every authentic part can be replaced in its original position and no stone is replaced unless there is certainty in this respect, need to be mentioned separately:
\end{abstract}

The ruins, which lie on the road between Yogyakarta and Surakarta, have been known for a very long time. They have been visited repeatedly and had been partially cleaned up to facilitate closer study and surveying. Nonetheless, until late last century, they were little more than lumps of stone and hillocks luxuriantly bedecked with bushes.

In 1885 IJzerman was the first to attempt to bring some order to the Loro Jonggrang complex. The blocks of stone which had crashed down into the temple chambers were removed. He had no intention to undertake any restoration, nor did Groneman, who not long thereafter radically set to work and had all the rubble which had collapsed around the ruins removed and thrown onto one large pile. He was probably unaware of the fact that his actions would horrify Brandes, whose hopes of a possible reconstruction were completely dashed. It later turned out that Brandes had been too gloomy, although the rough and ready way in which the basements had been exposed was to cause later workers great and unnecessary difficulties.

In 1902 and 1903, Van Erp, the able restorer of Borobodur, undertook the first architectural steps when he restored the subsidiary chambers of the main temple, which were in a ruinous state.

- First published in Djāwẩ 20 (1940), pp. 234-9. Translation by Rosemary RobsonMcKillop. Editor's note: Not all of the plates from the original article are reproduced here. Some of the irretraceable plates have been replaced by similar photographs. 
Work on Prambanan by the Archaeological Service recommenced in 1918. The architect, P.J. Perquin, who had just completed the fine reconstruction at Panataran, was put in charge of the work. We have to admire the courage with which he faced the chaos and, step by step, wrested the old form from the thousands upon thousands of stones. When De Haan took over the work in 1926, not only was the frame of the southern chamber entrance rebuilt, but the form of the building to the height of the cornice could be envisaged. This was when the idea of a complete restoration, instead of the original idea of just replacing a few of the pieces or of a partial reconstruction of some of the façades, first took root.

This change, engendered by the work which had been accomplished, caused attention to turn to the question of restoration, which in turn led to a request for advice addressed to the architect [H.P.] Berlage, who was then (1923) spending some time in the Indies. However, his advice leaned too heavily on Dutch principles to be really satisfactory. Not long afterwards the problem was placed before the restoration commission which had been formed in the Netherlands Indies for this purpose, and which included such people as Van Erp. This commission laid down extremely fundamental guidelines to be followed during the restoration and rebuilding.

On the basis of this verdict, and building upon the work of Perquin, De Haan continued in this project until 1930, when a serious illness claimed his life. In the meantime he had had the opportunity, alongside his other work, to prepare for the restoration of both the so-called 'court' temples [in Dutch: hoftempels, in Indonesian: candi apit].

At the beginning of 1931, the author of this article was put in charge of the work. The drastic economy measures introduced by the government, reducing the working day to half a day, meant that in 1932 the tempo of the work had to be reduced. Besides this, the architectural inspector also had to take on a fulltime teaching position, which meant that he had only one day per week and the school holidays to devote to his original duties with the Archaeological Service. During this period the day-to-day running of the operations lay in the hands of the deputy architectural inspector, P.H. van Coolwijk. Notwithstanding all this, the whole form of the building was successfully retrieved, which meant that, after a meticulous check of the provisional reconstructions already carried out, the reconstruction proper could be commenced at the end of 1937. This work was paid for by 25 million [guilders] from the Welvaartsfonds (Welfare Fund). It was estimated that the work would take about seven years, so that it was hoped that by 1945 Java would be enriched by yet one more cultural monument, which would have no parallel within the borders of the Netherlands Indies.

As may emerge from this historical introduction, this great undertaking so 
caught the interest of archaeologists and architects that voices were soon heard urging a fundamental rethink of the methods of reconstruction. Initially this work was undertaken fairly haphazardly, only partial repairs being carried out with the aim of making the most conspicuous of the ruinous façades more presentable. Therefore, with this aim in mind, it is easy to understand that intact pieces from other façades had been used to replace original stones that were either beyond repair or had completely disappeared. It is equally understandable that this method won neither the confidence nor the approval of everyone and people began to ask if these were not the first steps of a slippery path that might eventually lead to falsifications, in this case the arbitrary - indeed insufficiently controlled - placing of frames and building elements. In view of the not wholly reliable restorations of Pawon and Mendut, the question was raised of whether rebuilding was even a feasible option.

A paper war flared up, fought out in part in the pages of the journal Djåwa. One stance was adopted by the party which sided with Berlage and agreed with the stipulations laid down by the Nederlandsche Oudheidkundigen Bond (Dutch Archaeological Union), which stated that buildings which were no longer in use, thus Hindu-Javanese temples, would be deemed suitable only for conservation measures. The other party was composed of those who applauded the reconstruction of cultural monuments, as long as this was carried out in a scientifically responsible way. This latter point of view was accepted ad hoc by the commission, which meant that the reconstruction work of the Archaeological Service was subjected to extremely high scientific stipulations; no attempts at actual reconstruction were to be undertaken until there was absolute certainty that every authentic piece could be returned to its original location. Let it be emphatically stated here that now no single stone is replaced about which there is the slightest doubt; such a stone is set aside as unplaceable.

Before commencing on the reconstruction of an antiquity, the monument is assembled on the ground in sections in what are known as trial reconstructions. These are fragments of a temple some three to four metres high, in which the original stones have been put back in their places interspersed between supplementary material, which is used provisionally to take the place of pieces which have been lost. Easily worked material (marlstone or sandstone-lime bricks made on site) are used to make these replacements, bearing in mind that the original stones may be found again before the definitive reconstruction of the building has taken place. These trial reconstructions, which are known as be!ts, are a final check on the accuracy of the reconstruction made earlier on paper, about which we shall say more later.

Likewise, before any attempt can be made to make a trial reconstruction, there is an enormous sorting and sifting operation, which entails partial trial 
reconstructions. This has to be tackled mechanically, because at the outset of the investigation there are scarcely any indications available about the details of the building. The person attempting the reconstruction has no old drawings or stylistic data at his service. Each building presents its own special surprises and the surviving manuals for the builders, śilpaśāstra, are not from Java, nor are they sufficiently open to the non-philologist to be able to be used as a handbook during the reconstruction. What this boils down to is that there is only the material which has been found, and nothing else, with which to work. In the case of the Śiva temple at Prambanan, the only indications, apart from the material itself (namely, the locations of the materials, which at least give some idea of which piece belongs to which façade), had been lost as the result of Groneman's enthusiasm. Therefore, we reiterate out admiration for the courage behind the attack on the great pile of rubble to the west of the temple site at Prambanan. To this we add our great esteem for the Javanese overseers, who with extraordinary intuition and accuracy were able to put the most unlikely fragments back together. How this all came about is set out below.

To arrive at some sort of idea of the amount of puzzling involved in this, the best thing one can call to mind is a jigsaw puzzle, composed of oddly cut pieces of triplex. Having done this, one has to add a third dimension, because the matching pieces above and below each piece also have to be sought and found. As with a jigsaw puzzle, the pieces were first selected according to colour or some other characteristic, so the stones showing special peculiarities were provisionally assembled together. After the first rough division, for example into flat mouldings, ornamented mouldings, pieces with geometric designs, with arabesques or with scenes, a closer selection took place. Finally, similar pieces could be placed together, after which it was up to architectural insight to put all the pieces assembled together into an architectonic unit. The initiative lies in the hands of the person carrying out the work, but it is the stones themselves that confirm the hypothesis. Each time this hypothesis proves to be wrong, a fresh solution has to be sought.

What are the special characteristics by which similar sorts of stones are assembled and what methods of control can be useful in this process? The answer emerges from the ancient building technique, of which the most immediately striking features are: first, that the stones are of different sizes; second, that the stones from the higher levels were set onto the pieces below them by means of a tongue set into a groove; third, that in many places the stones are anchored sideways by stone dowels, and at the back with a swallow-tail joint; four, that the ornamentation was carved later, thus also covering the joints; five, that the original stones were dressed on the site (in the building itself); six, that the 
stones were not always dressed rectangularly, but nonetheless fit into each other with tenons.

What these points show is that once upon a time each stone underwent an individual treatment and thus has idiosyncratic characteristics. The tongue and groove on two stones set one on top of the other each have their individual measurements, which means that they do not fit onto other pieces. In some places one can find traces of some redressing, after the stones had been put into place. The dowels or the swallow-tail joints of two stones which lay next to each other must correspond to each other, as should a groove which continues over a number of stones. Not only should the ornamentation flow onto the adjoining stones, but the chisel marks should also run on over the joints. Finally, the dressing of the stones was done so accurately that, generally speaking, it can be assumed that the joints must also lock inside.

These means of control are so numerous that once one has grown accustomed to them one can feel certain that the stones which fit together also belonged together in the past. The job becomes more difficult when various characteristics have been erased by damage or weathering. A special difficulty is raised by those stones which were dressed during the process of earlier restorations. It is impossible to estimate the extent of the amount hewn off, other than to learn to recognize it through reduction, namely by pretending that a stone is missing between this stone and the one which lies next to it.

This leads us to one of the most difficult points in the reconstruction work, namely the determination of the sizes of spaces occasioned by the disappearance of the original pieces. Theoretically, on the reconstruction drawings, it is possible to determine fairly accurately the size of the remaining open spaces. However, in practice these have to be meticulously checked, because in work done by hand (which such a temple can be considered) there are always inaccuracies. In this case, purely mechanical research methods have the last word. In such an instance, the trial reconstruction has to be built up until at a higher level a continuous line is achieved and the gap caused by the loss of material has been closed in on all sides by the original work. This requires extremely accurate work and these trials have to be dismantled and begun again several times. The same difficulty arises in the openings of the gates, in which, to make matters worse, the horizontal joints for the doorposts are not at an equal height.

To recapitulate, in a reconstruction the following activities are carried out:

1. sorting the stones according to size and shape,

2. stricter sorting according to characteristics of details,

3. partial reconstructions, 
4. the making of reconstruction plans,

5. trial reconstructions of horizontal sections,

After this, having obtained a satisfactory degree of certainty about the original shape, the actual work of reconstruction can commence.

In the middle of 1937, money became available for the rebuilding of the Siva temple. In view of the fact that the temple was already assembled in trial sections on the site, work on the the reconstruction, which had been planned in advance, could be set in motion immediately. The first step was to buy $270 \mathrm{~m}^{3}$ of timber for the massive scaffolding, with two lifts worked by hand-winches, which had to reach above the cornice of the building. While this was being done, partially replaced sections of the façade were dismantled and added once again to the trial reconstruction to which they belonged. Any of the remaining sections of wall which had been displaced by the long period of decay were dismantled and then put back in their proper place. When this had been done the blocks were joined to each other by wall-ties and, wherever possible, this was done at the back as well. When the scaffolding was ready, which took a good year altogether, the trial reconstructions on the site could be dismantled one by one and be replaced definitively in the building.

In this rebuilding process, the necessity for absolute accuracy is even more compelling than during the trial reconstructions. Indeed, the higher one goes, every irregularity in the underlying levels is multiplied and can eventually lead to the situation that the topmost layers do not fit.

However tempting it may be for the architect to set out his joints and cornices with a plumb and a water level, when old stones are being replaced this is exactly what should not be done. Extremely marked deviations, particularly of the horizontal lines, and even in the vertical lines, show that these tools were not used by the original builders. For this reason, during the rebuilding, the methods used as a check during the trial reconstruction must be used with even greater strictness. Whether two areas flow smoothly across a groove is determined by running a hand over it, while cornices are adjusted with the eye. Guys, plumb, and water level play only a very secondary role.

For as far as this was possible, the fragments which had flaked off were put back in their original positions with rust-free metal. New stones that had to be added were hewn exactly along the fracture lines of the old ones, from which nothing was cut off, in order to ensure that no single fact should be lost which might lead to rediscovery of the authentic place.

The stones were piled carefully, one on top of the other, without the addition of any mortar, after which the joints were filled with an extremely liquid variety of cement (one part cement to one part sand) or with pure cement water in the case of very narrow joints. However, before the joints were filled in, those joints 
which were exposed to the daylight were sealed with damp clay, so that the cement could not drain away. After the clay has been removed, no cement is visible and the building retains its original external appearance.

In this reconstruction the use of iron was avoided in any places where it would be exposed to humidity or the open air. The iron ducts that had been added to the drains in the galleries during the previous reconstruction were replaced by reinforced concrete constructions. Likewise, the iron girders that had been placed under the thresholds were replaced by setting reinforced concrete constructions in the thresholds. The iron wall-ties, by which the external wall was attached to the additional concrete mass, were provided with extra cement in order to prevent corrosion.

In order that this concrete mass, just mentioned, should not become too expensive, it was kept thin and the rest of the interior work was carried out with the usual river-stone masonry.

It is impossible to completely protect the enormous mass of stone against earthquakes. Should this colossus begin to move, it would imply the presence of such great forces that only ridiculously heavy structures would be proof against them. The outer wall is protected against detachment from the central body during a severe earth tremor by a concrete skeleton consisting of a construction of horizontal circular beams and vertical columns.

As was just mentioned, the broken thresholds were strengthened by reinforced concrete joists. This involved hollowing out the whole of the threshold, and then the concrete joist was poured into the resulting cavity. The same system was used for the covering of the passageways with stone slabs, which were laid in a reinforced concrete floor.

Unfortunately, the proper shape of the pseudo-vaults, which were restored by Van Erp, is not known. This is the reason that clearly visible concrete groins have been used, so that it is obvious that the original vault could not be restored but has been replaced by a modern substitute.

Now we have reached the finishing off of the building. Scientific verity demands that a clear distinction be made between what is original and what has been renewed. This has been achieved partially because, convinced that free ornamentation, as originally applied, cannot be imitated, no new decoration was used on the new stonework, the restorers having restricted themselves to the placement of pilasters and mouldings and the indication of simple geometric ornamentation. Furthermore, each new stone was furnished with a lead seal.

Many are worried that the failure to continue the decoration onto the new stones will disturb the appearance of the façades. The rapid discoloration of the stones and the domination of the architectural line which has been retained will create such a unitary image that this anxiety must be considered unfounded. 


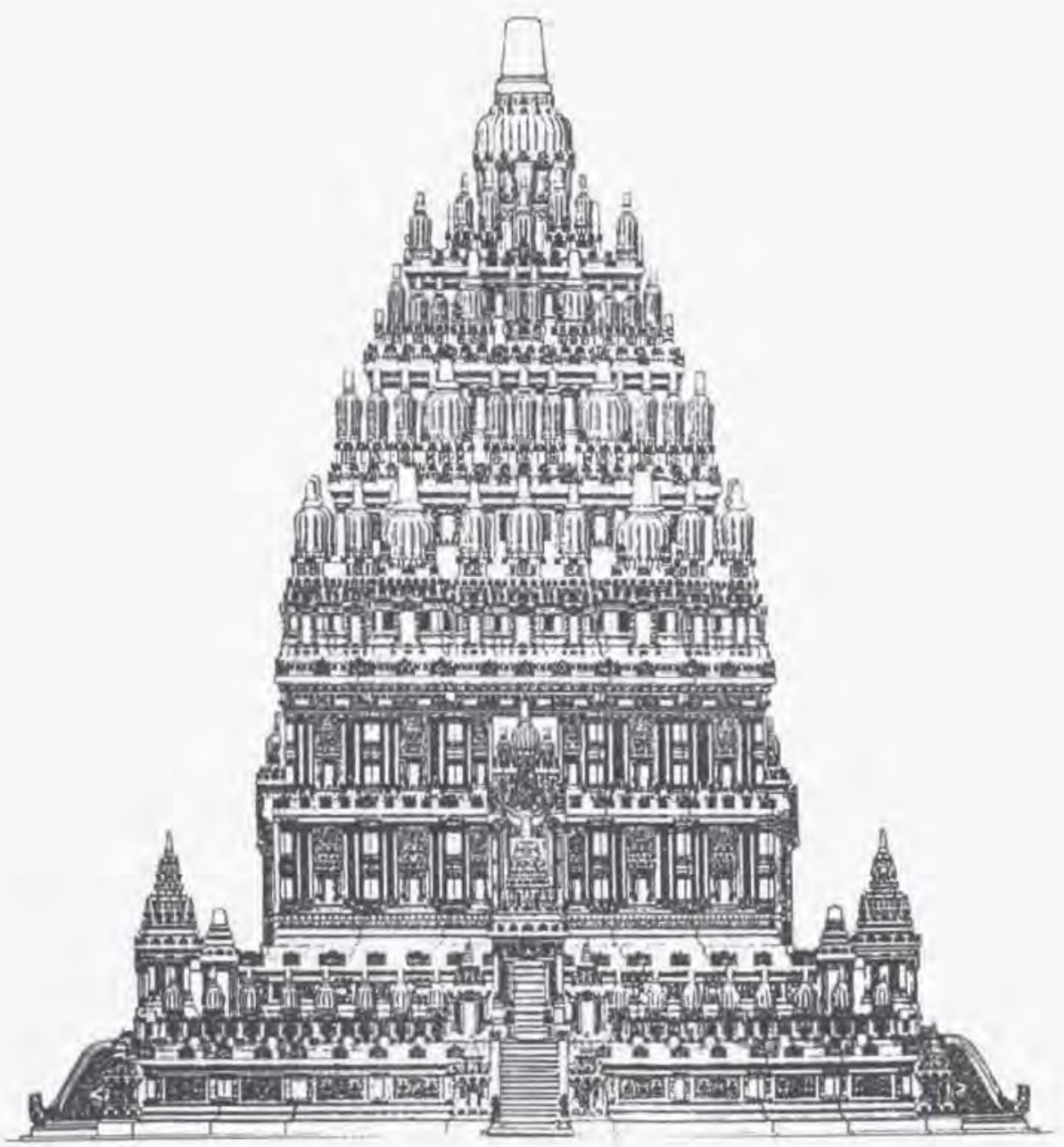

Figure 12. Reconstruction drawing of the Śiva temple (adapted from Djåwá 20 (1940), Fig. 11) 
The fields of the façades with the central panel and the niches, the numerous vertical lines of the pilasters and mouldings, the horizontal lines of the finials of the niches, all of which are continued in the new stonework, provide such a rich gradation of light and shadow that the absence of free ornamentation will not be so readily observable. So that there will not be too great a discrepancy between the very dilapidated old sections and the flawless stones which have been inserted between them, here and there it was necessary to cover or replace the most glaring damage (holes and so forth). This was resorted to as little as possible so as not to detract from the character of the monument.

The adjacent drawing of the reconstruction (Fig, 12) [here p. 182] shows how the earlier builders probably conceived the complex. Naturally, it is impossible to say if it really did look like this. Many of the drawings of the ruins that remained seem to indicate that the complex was never finished. There is even a possibility that some of the temples were never given their superstructures. This is something which may be demonstrated by the research which is to be continued.

When the nearly $50 \mathrm{~m}$ high building ( $20 \mathrm{~m}$ higher than the scaffolding) finally soars up again as the result of more than eighteen years of searching and seven years of building, our first sentiments will be ones of gratitude to the Netherlands, which made it possible for us to contribute to the partial revival of one of the cultural monuments of Java's splendid past. 


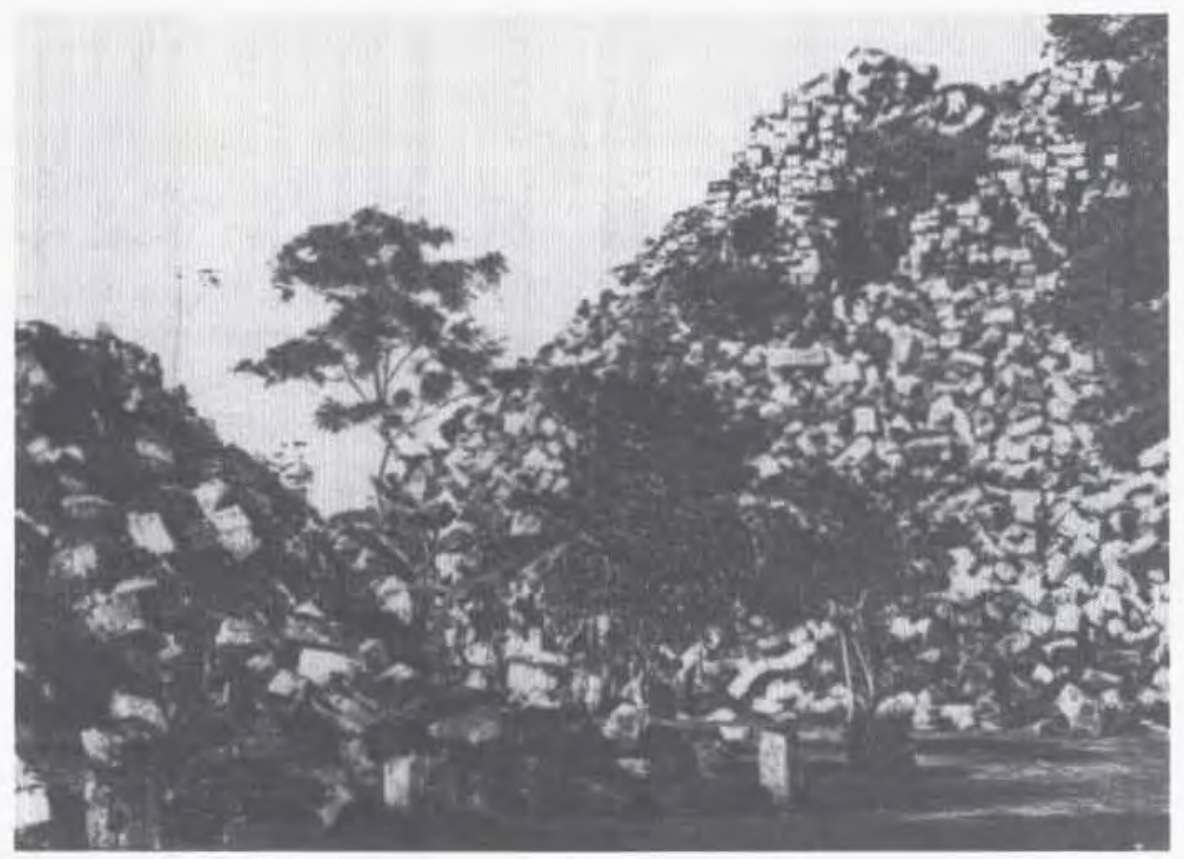

Photo 12. Temple ruins at Prambanan in c. 1880 (reproduced from Djåwå 20 (1940))

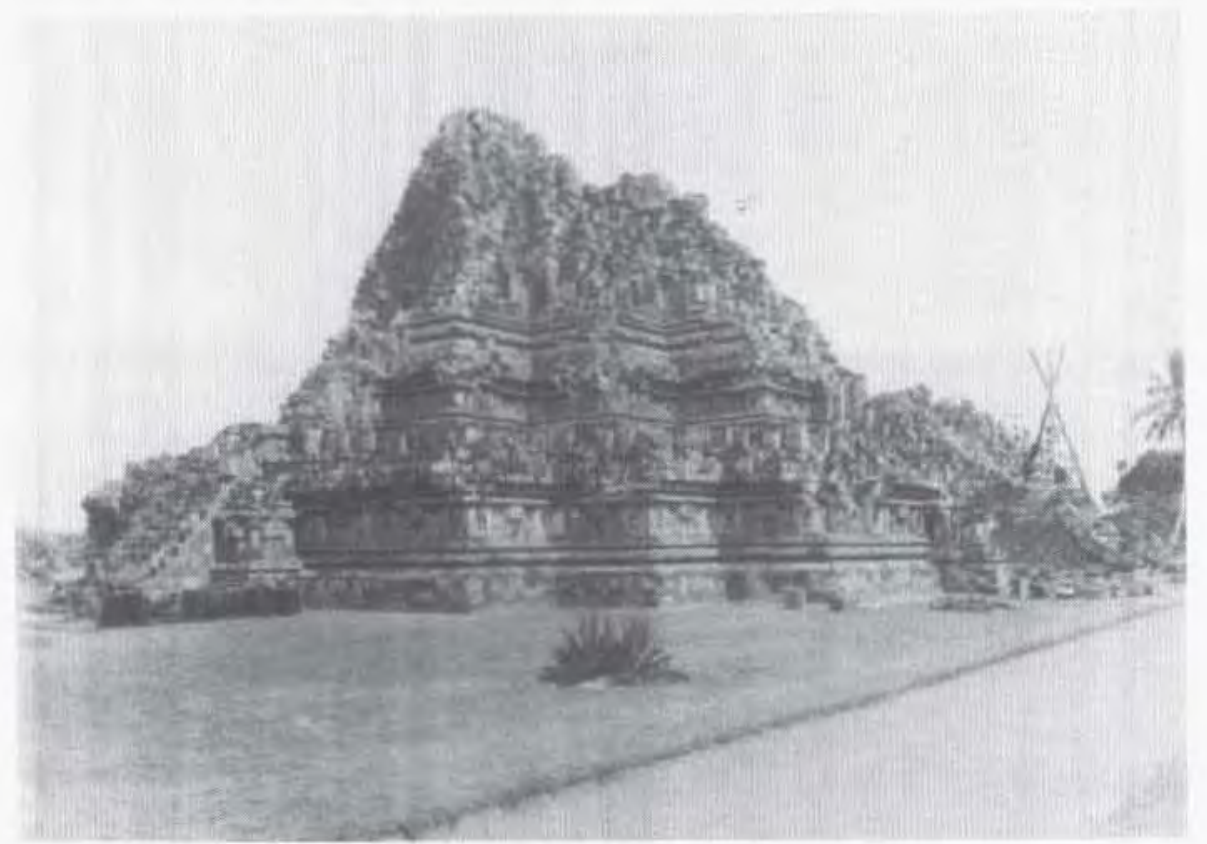

Photo 13. The Siva temple after the rough clearing by Groneman in c. 1890 (OD 4007. Courtesy University Library Leiden) 


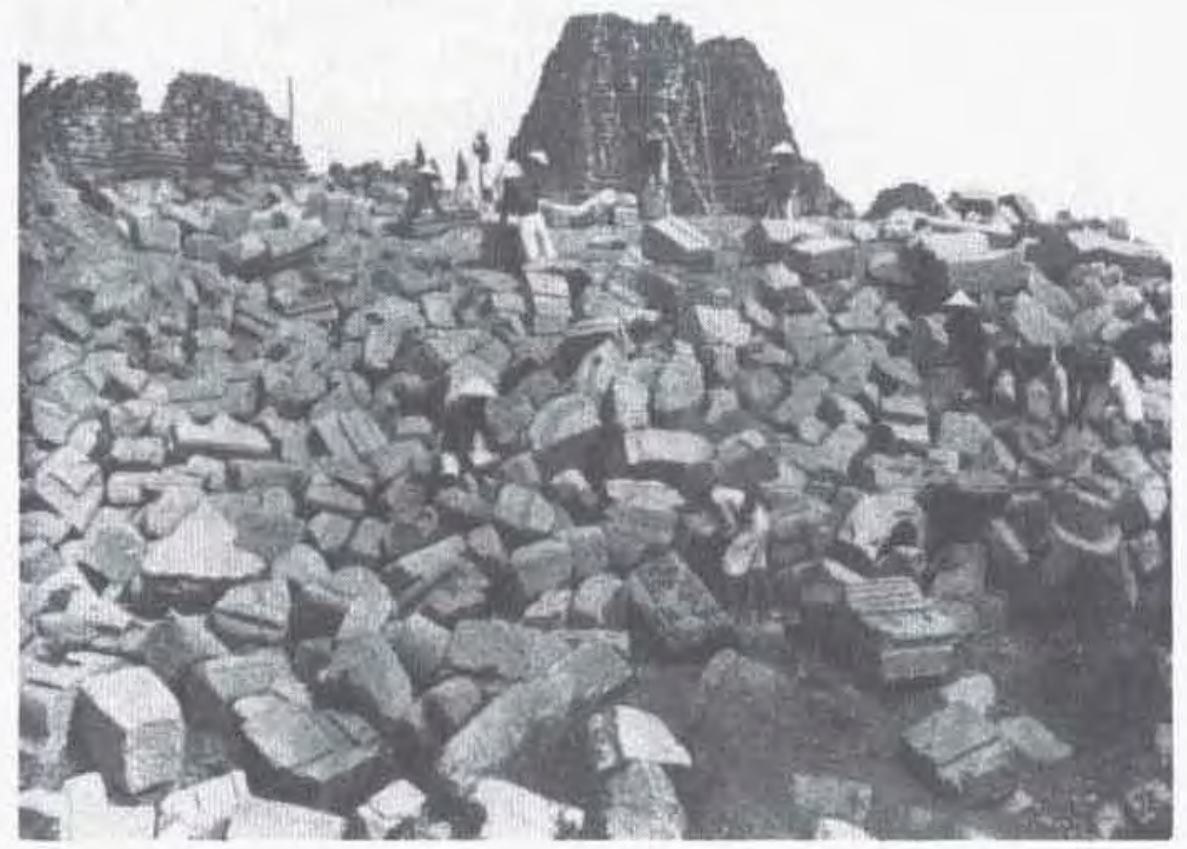

Photo 14. Javanese labourers exploring a pile of stones (OD 4018 reproduced from Djăwă $20(1940))$

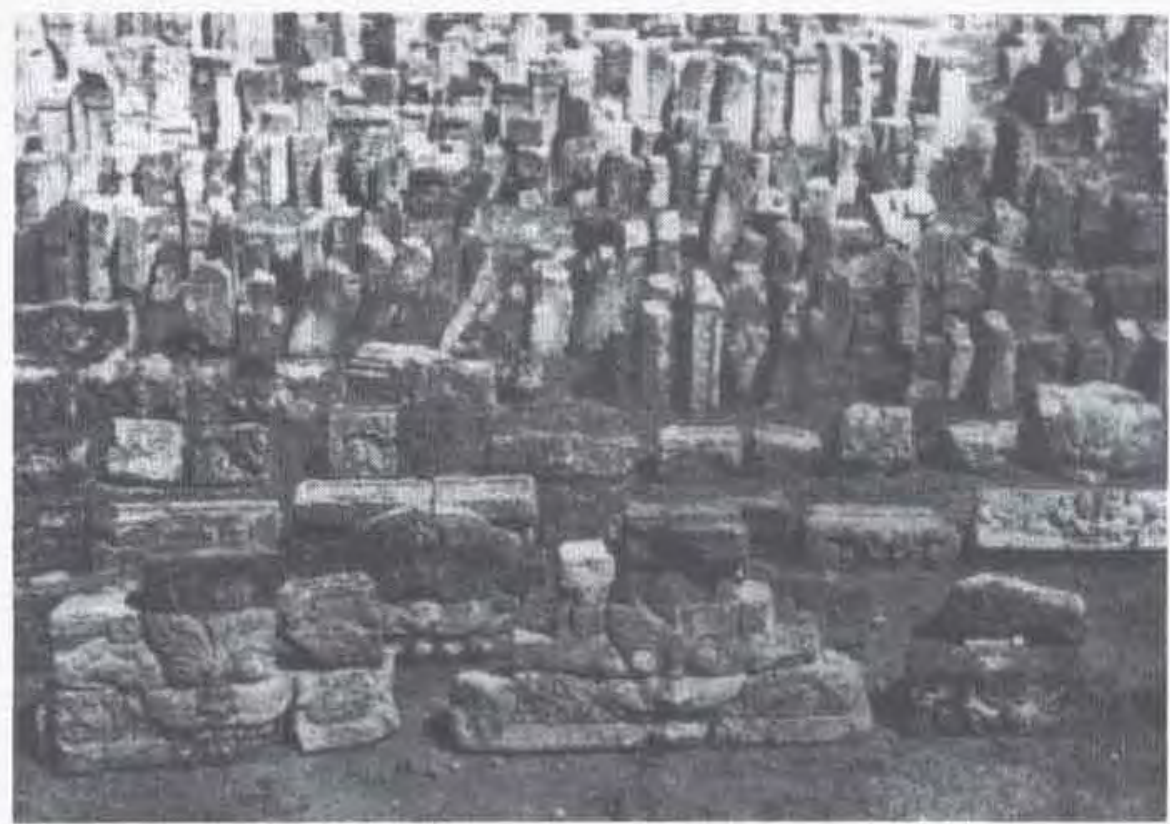

Photo 15. Sorting the stones according to size and shape (reproduced from Djäwd 20 (1940)) 


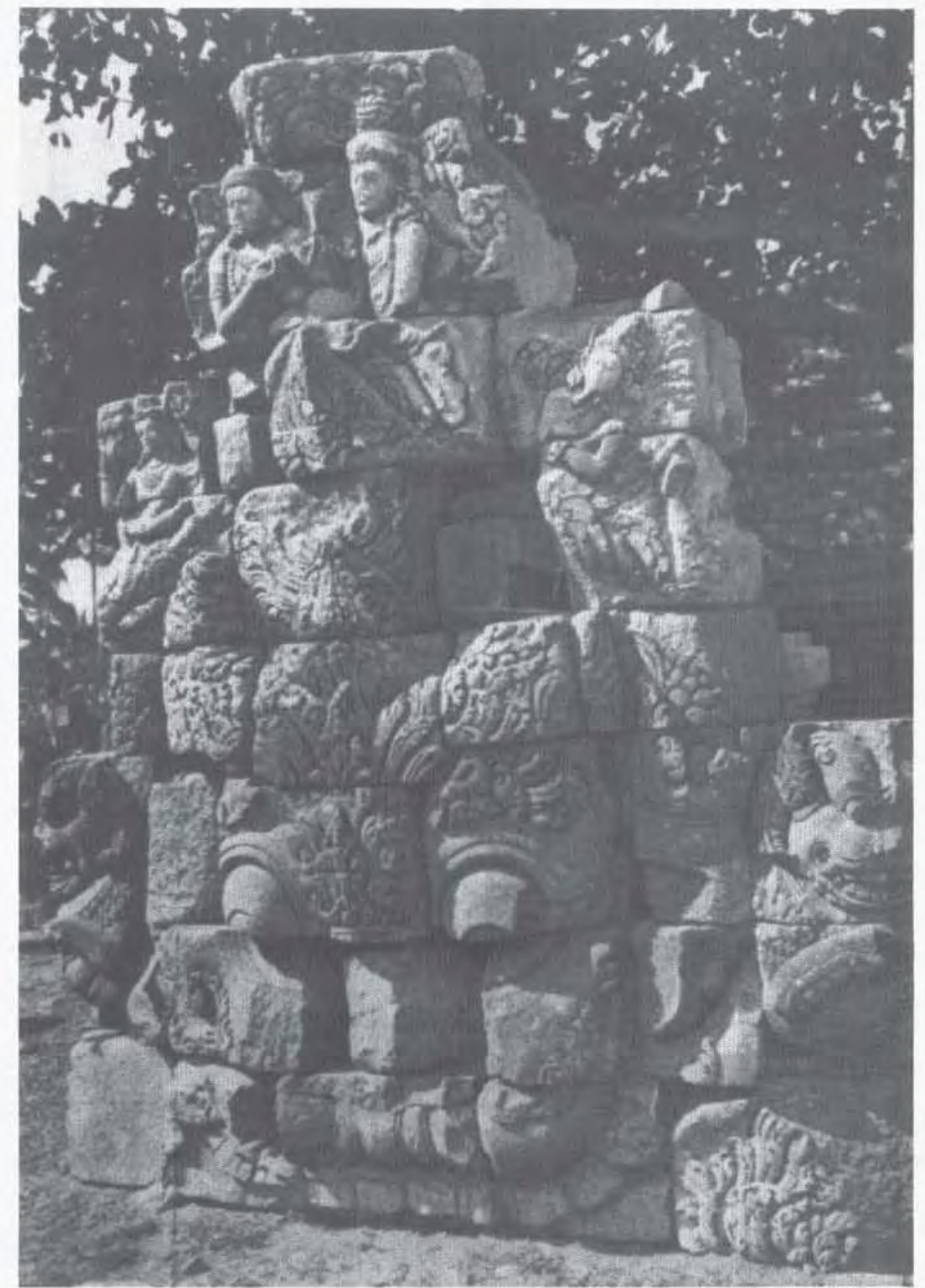

Photo 16. Partial reconstruction of a Kāla head (reproduced from Djåwå 20 (1940)) 


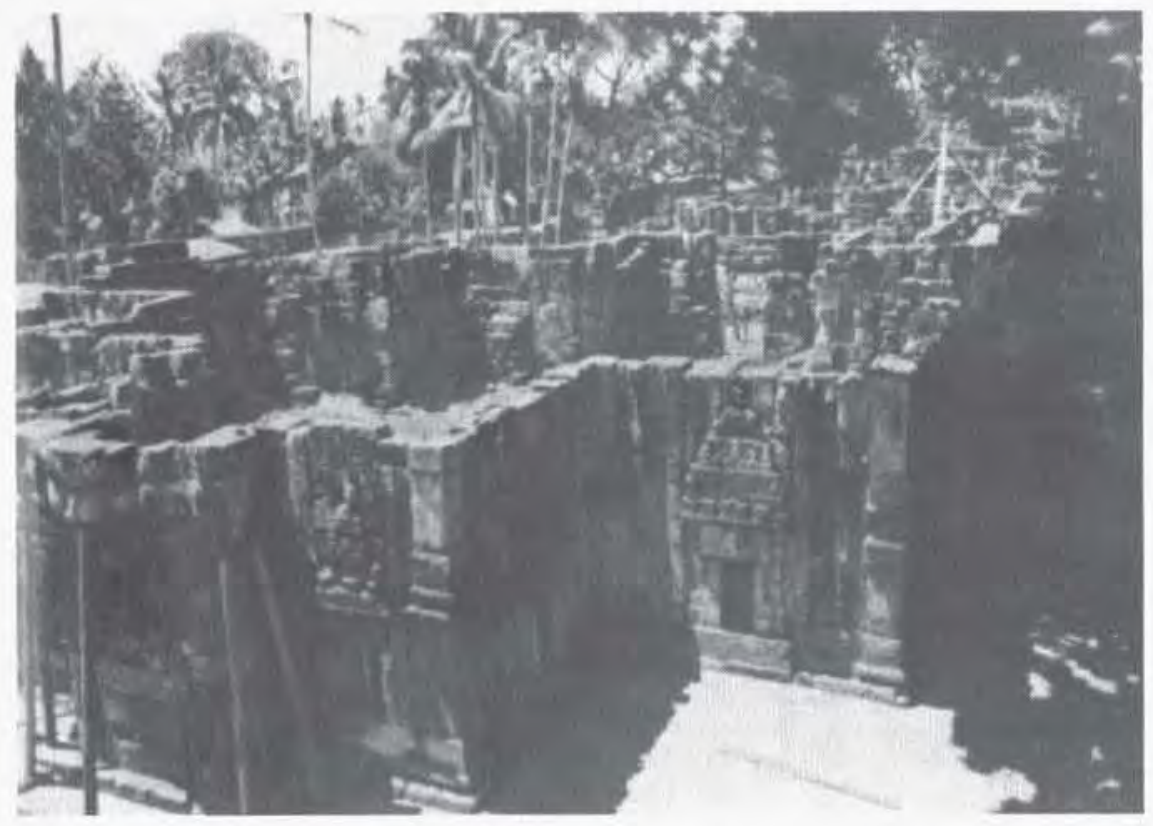

Photo 17. Mock-up or trial reconstruction of a horizontal section of the wall of the Siva temple (OD 13297, reproduced from Djåwá 20 (1940))

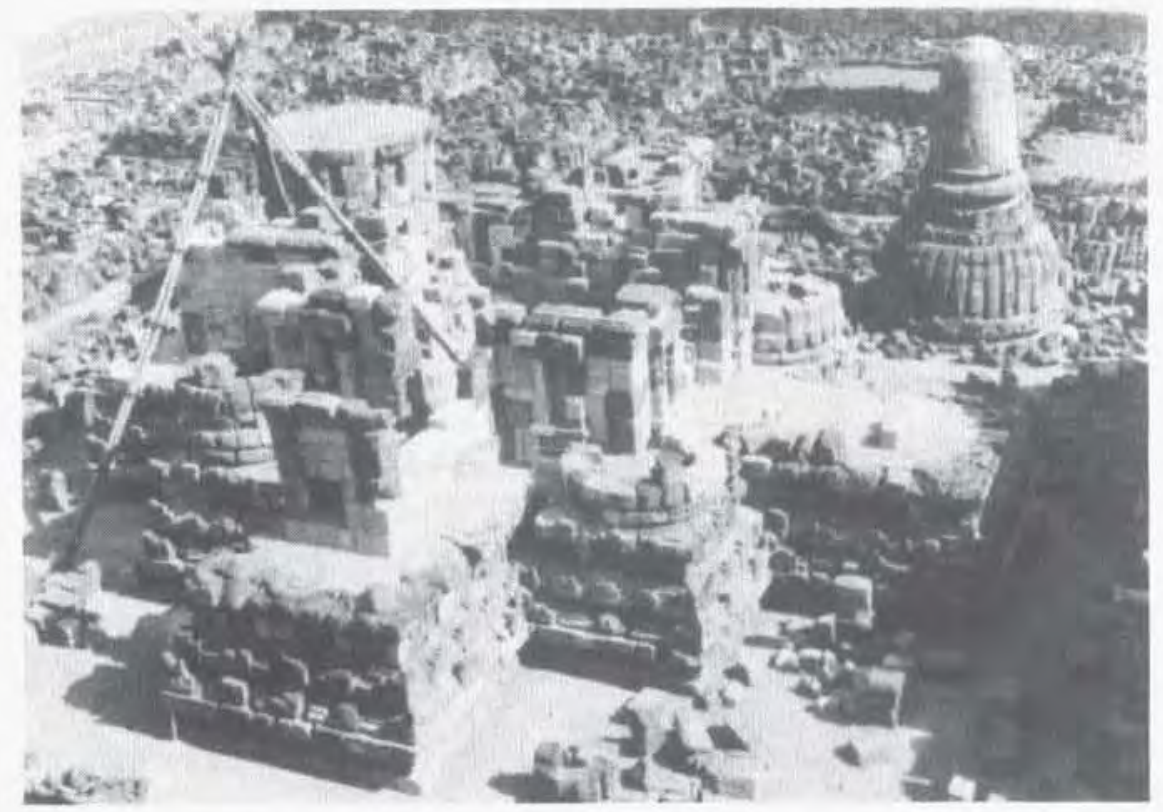

Photo 18. In progress: trial reconstruction of the upper part of the Śiva temple (OD 13302, Courtesy University Library Leiden) 


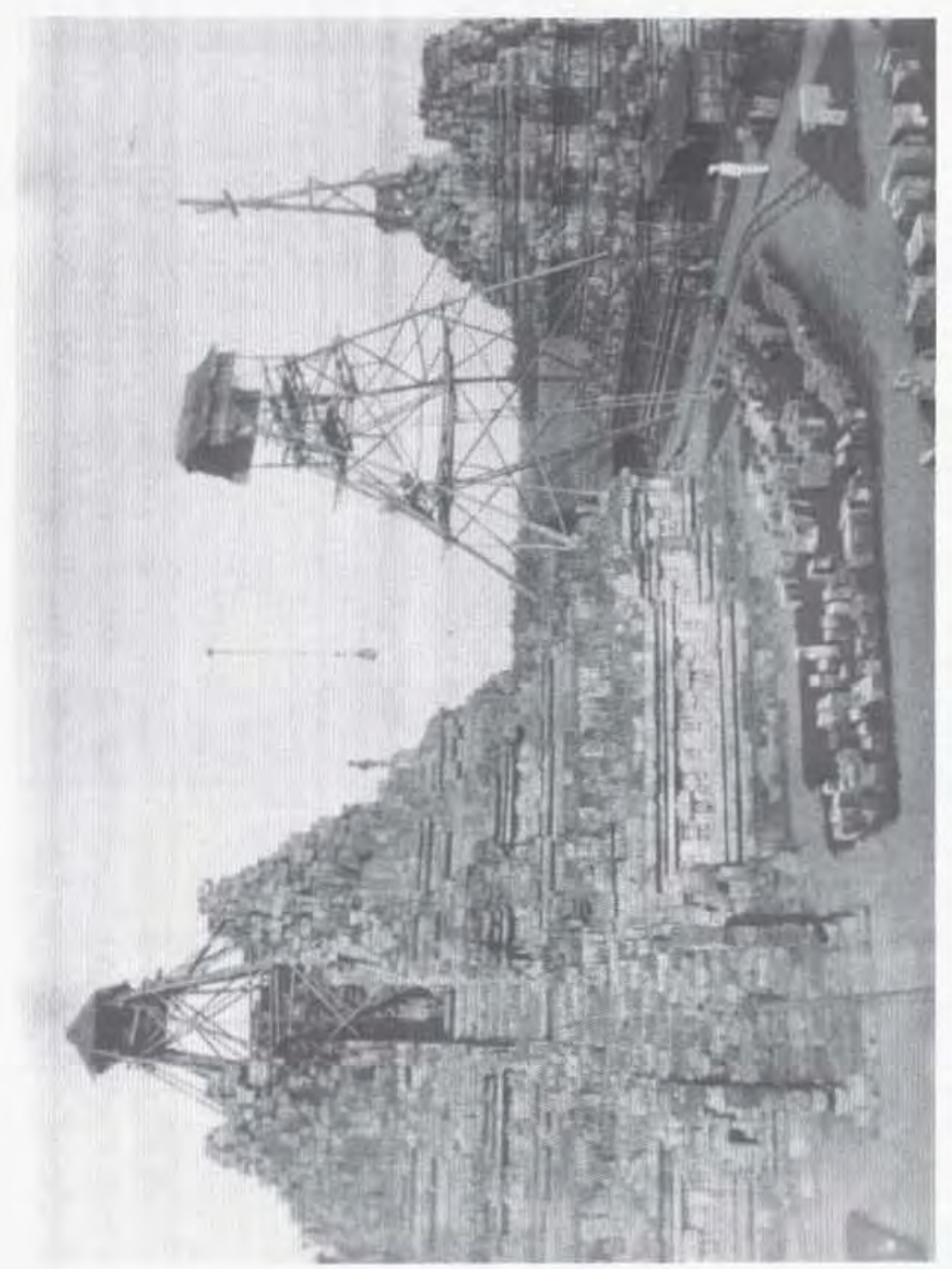

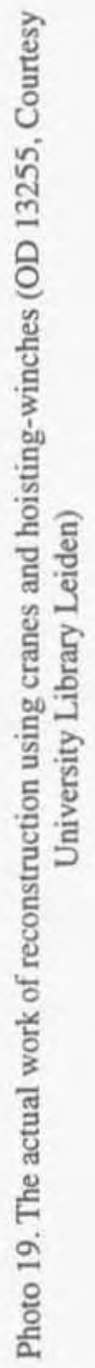




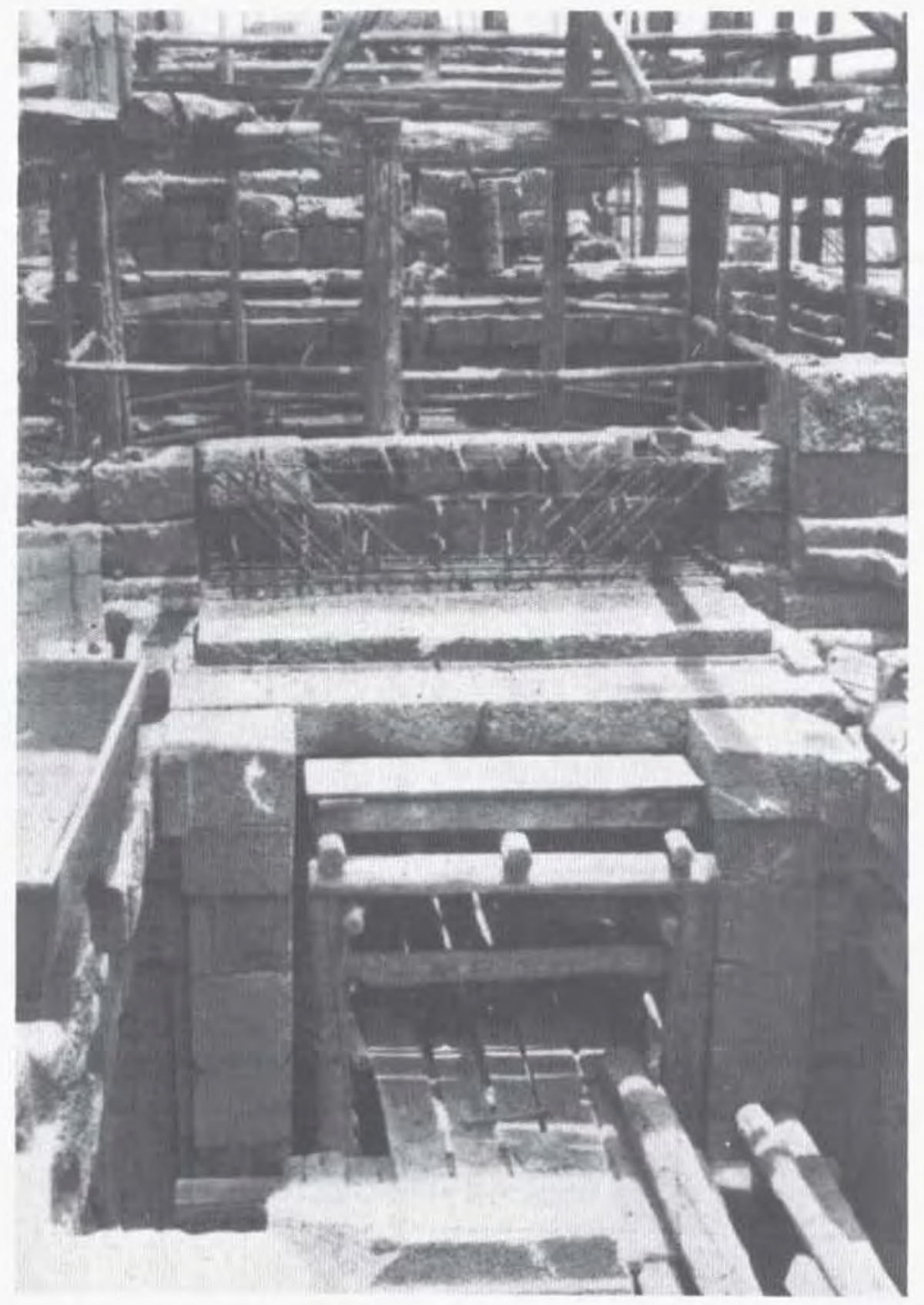

Photo 20. Reinforcement of a threshold (reproduced from Djåwå 20 (1940)) 


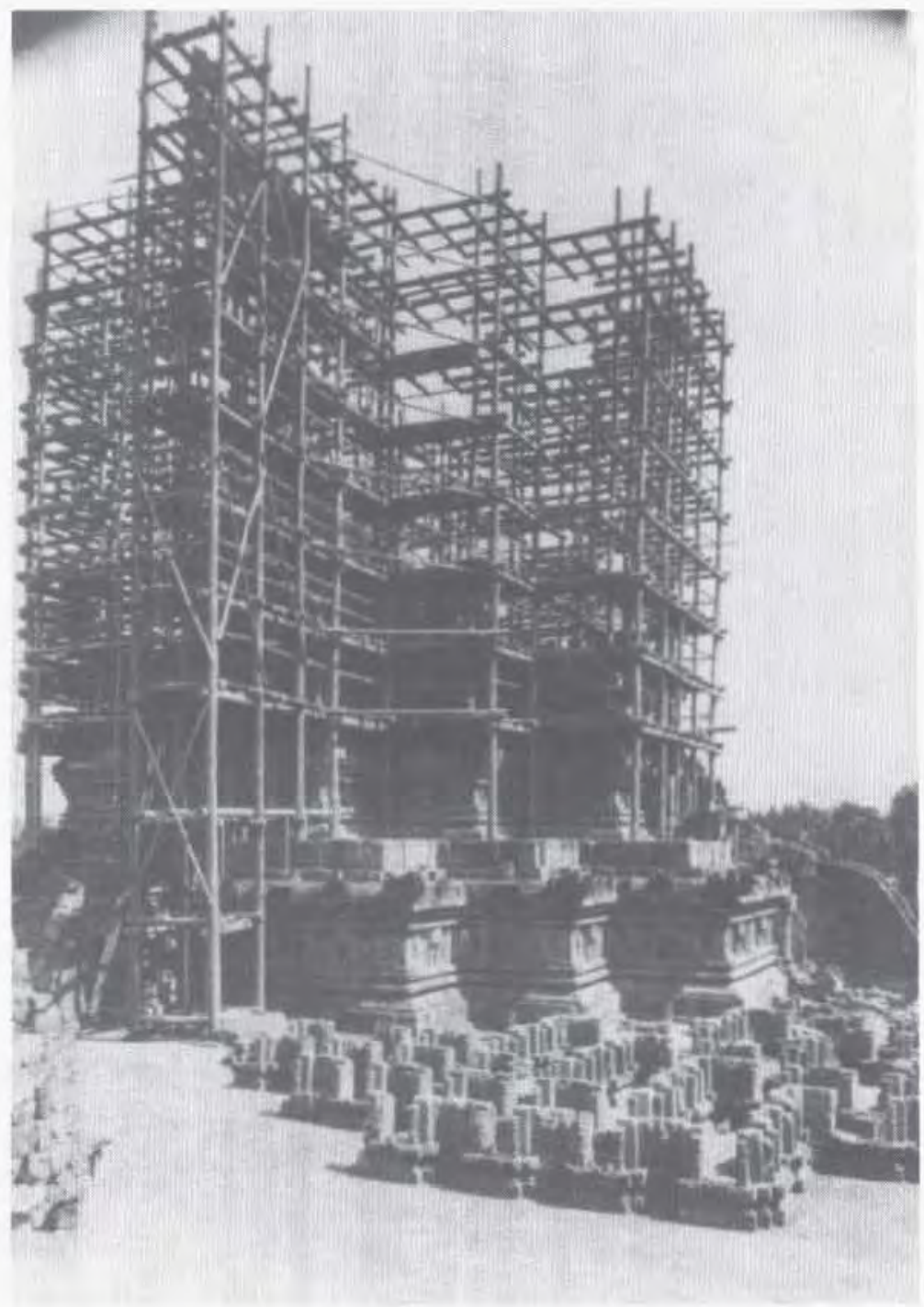

Photo 21. The scaffold used for the reconstruction of the Siva temple (OD 13255 , Courtesy University Library Leiden) 


\title{
A.J. BERNET KEMPERS \\ Prambanan 1954
}

\begin{abstract}
Although it overlaps slightly with some of the other contributions to this volume, the article by Bernet Kempers reproduced below deserves to be made accessible to a larger public through an English translation. With his characteristic thoroughness, Bernet Kempers gives a survey of the history of the reconstruction of the Prambanan temple complex, especially that of the Siva temple, in which he was closely involved as the first director of the Indonesian Archaeological Service. By its detail and exhaustiveness, the description of the architectural aspects of the main temple will prove a useful guide for the descriptions of other temples in this complex which still remain to be made.
\end{abstract}

A year has now passed since the completion of the restoration of the Siva temple in the Loro Jonggrang complex at Prambanan was celebrated with a great feast on 20 December 1953 (see Photo p. 192). This marked the splendid conclusion of the largest project ever undertaken by the Archaeological Service in Indonesia. As a regular visitor, my intention in this article is to take the liberty of giving an eyewitness report about some of the things which are to be seen and which are happening now, the end of 1954, at Prambanan for those who do not have the fortune to witness this for themselves. To a certain extent this is like a snapshot, because even now that the main temple is completed, the work still to be done in this huge complex is by no means near its end. This is the reason for the choice of the title: Prambanan 1954.

Presently, I fear, it is inevitable that I shall have to mention some more dates and facts in order to underscore the importance of what has taken place here. But, before doing so, I shall begin with a general orientation of the site.

You will recall that, besides the Śiva temple, the Loro Jonggrang complex contains a large number of other buildings. To the north and south of this main temple, and in alignment with it, are those dedicated to Vișnu and Brahmā respectively; opposite them are three smaller buildings that were formerly

- First published as 'Prambanan, 1954', Bijdragen tot de Taal-, Land-en Volkenkunde 111 (1955), pp. 6-37. Translation by Rosemary Robson-McKillop. Editor's note: Not all of the photographs from original article are reproduced here; owing to a lack of proper identification of the photographs, these could not all be located. Some have been replaced by suitable alternatives. 


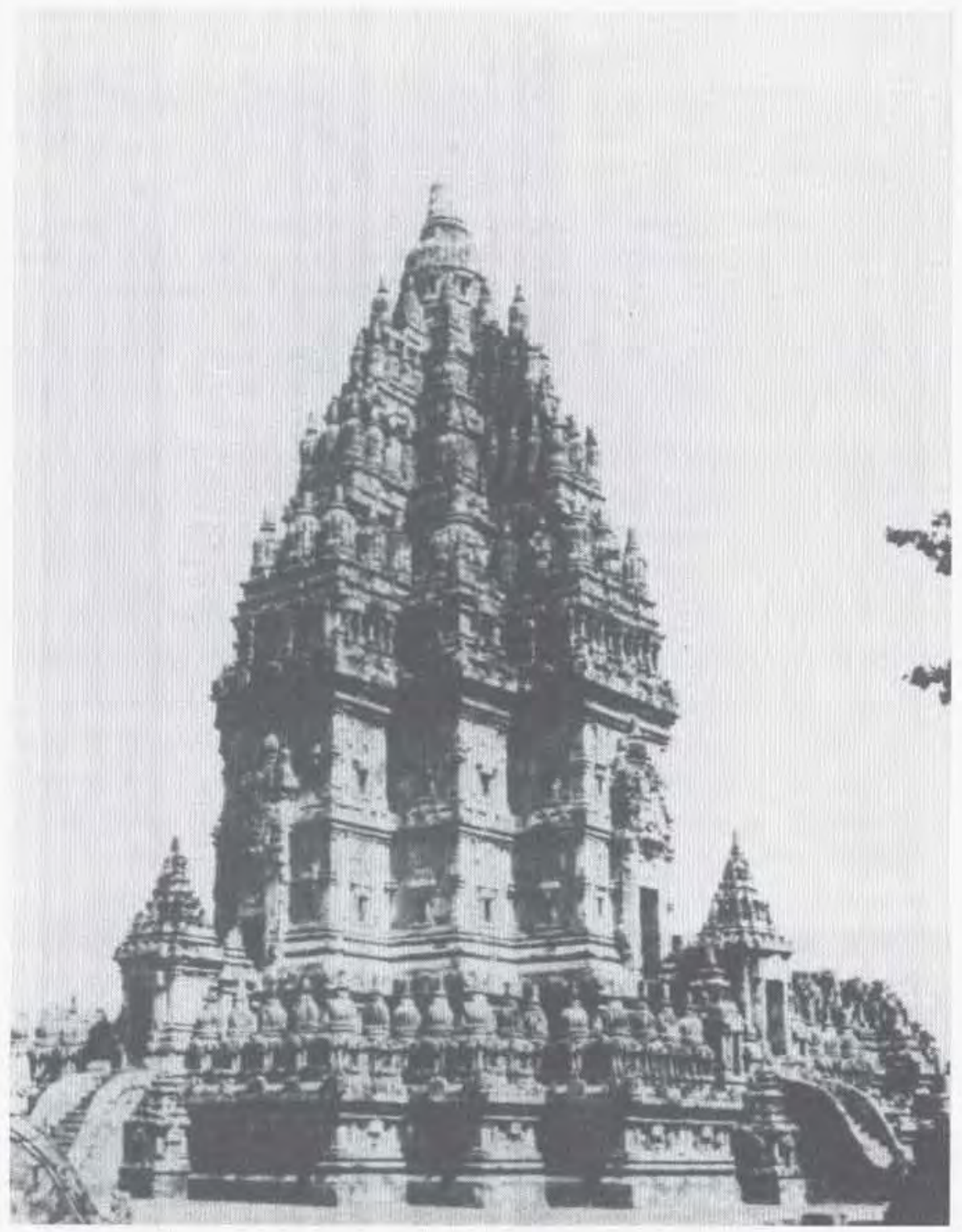

Photo 22. The reconstructed Śiva temple (photograph Roy E. Jordaan, reproduced from Bernet Kempers 1978:8) 
referred to as vāhana temples. This designation is somewhat inappropriate in that only the middle one contains a vähana, ithe animal used by the deity as a mount: Nandi, the bull of Siva. The other two temples, now prosaically designated A and B, possibly housed special forms of Siva. In fact, B (the northern one) does indeed contain a statue of Śiva, of which the head is to be found in the Museum in Jakarta. The Garuda, which was located in this temple for a long time, now, after a brief sojourn in the Museum Sono Budoyo, has been placed in front of the Service Office at Prambanan. It did not originally come from candi B, nor indeed from anywhere else in the complex, but during the time it was believed to belong in the complex it was housed in the temple opposite the Vișnu temple. In order to give some idea of the size of these six temples: the Siva temple is 34 by $34 \mathrm{~m}$ and $47 \mathrm{~m}$ high, Brahmä and Vișnu are about 20 by $20 \mathrm{~m}$ and $23 \mathrm{~m}$ high, $\mathrm{A}$ and $\mathrm{B}$ are 13 by $13 \mathrm{~m}$ and $22 \mathrm{~m}$ high, and the Nandi temple is 15 by $15 \mathrm{~m}$ and $25 \mathrm{~m}$ high. With the exception of those of the main temple, these elevations are of course approximate. ${ }^{\prime}$

At the northern and southern extremities of the courtyard containing the six temples stand what are called small 'court' temples (in Dutch 'hoftempeltje', in Indonesian candi apit, from apit = adjutant, attendant). ' These measure 6 by 6 $\mathrm{m}$ and have an elevation of about $16 \mathrm{~m}$. The whole complex is situated within a square that is marked by small corner and 'kelir' temples ( 1.55 by $1.55 \mathrm{~m}$ and $4.10 \mathrm{~m}$ high), which are enclosed by a surrounding wall, the sides of which are $110 \mathrm{~m}$ long, the innermost or first of the complex. The centre of the square is not located at the site of the Siva statue, which forms the religious focus of the sanctuary in the main chamber of the Siva temple, but in the corner turret next to the southern side of the eastern staircase. Externally this corner turret is only distinguishable from the other seven flanking the staircases (see Figure 6) of the Śiva temple because it is open at the front. However, inside it there is a pierced pedestal and underneath this - invisible from the outside - is a column of three upright parallelopipeds, on which the centre of the site is indicated with fine

1 Measurement from Stutterheim, Djâwá 20 (1940), p. 225 seq. For descriptions of the complex in earlier days: there and Krom, Inteiding tot de Hindoe-Javaansche kunst (1923); Lulius van Goor, Korte gids (1919); Groneman, Tjandi Parambanan (1893); IJzerman, Beschrijving der oudheden (1891). The Ministry PPK in Yogyakarta published A short guide to the Lara Djonggrang temples (2nd impr. 1950) written by Soehamir, the linguistic section of the Jawatan Kebudayaan a Petundjuk tentang tjandi Rara (read: Lara) Djonggrang di Prambanan (1953). Maps in Djäwå 20 facing p. 235 and in Amerta 1 (Dinas Purbakala) (1952), p. 23.

- Editor's note: my interpretation differs from that of Bernet Kempers. $(H)$ apis had better be rendered as 'hemmed in', as is the case with, for instance, bulan apit, referring to the month Dzukaidah which lies hemmed in between the main Islamic festivals (see Juynboll 1930:110 note 2; Teeuw 1990:36). 


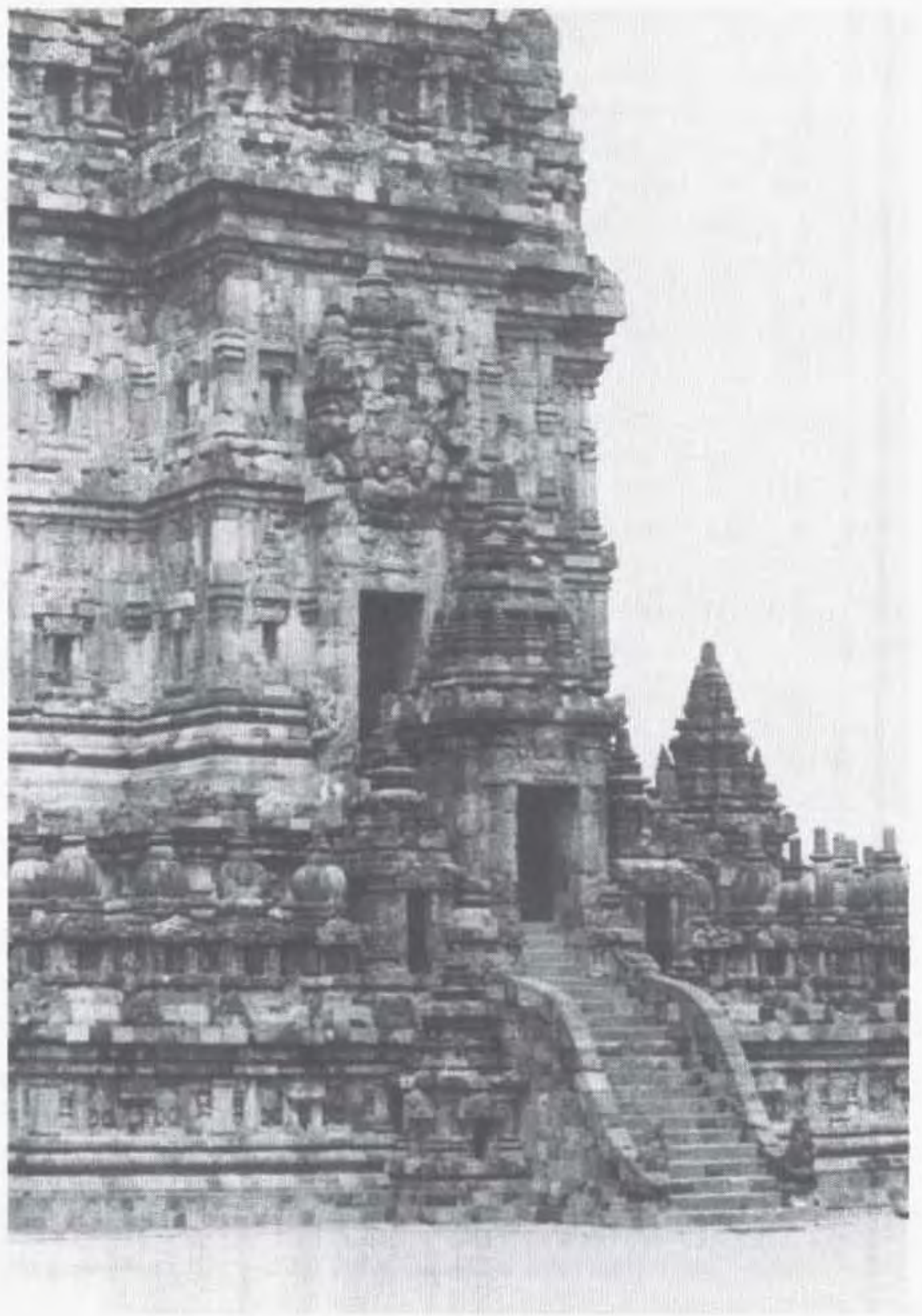

Photo 23. The eastern entrance to the Śiva temple. Next to the stairs is the turret containing the stones that mark the geometrical centre of the temple courtyard.

(Photograph Marije Duyker.) (See also Fig. 6.) 
lines. ${ }^{2}$ In other words, the main statue is not located at the geometrical centre but to the northwest of it. This off-centre positioning of the sacred focus is also found at various other sanctuaries (Gunung Wukir, Merak, Badut, Kidul, for example). Outside Indonesia there are also well-known examples: in Indian texts it is forbidden to site statues or important parts of buildings at the intersections of the ground plan of the construction. ${ }^{3}$ This sort of diagram is formed by a chess board pattern consisting of 64 or 81 squares, in which the most 'vulnerable' point is the intersection of the axes and the diagonals. As far as the central section is concerned, the plan of Loro Jonggrang is not as strictly symmetrical as is, for instance, Sewu; nonetheless it seems that it is still possible to discover other lines on the diagram besides the centre point which coincide with important sections of the temple plans and within which the subsidiary temples, to be mentioned presently, are located. This means that extremely detailed plans of the complex and of the temples are needed. At Prambanan, after the havoc wrought in the office during the Indonesian war of independence, there are now only a few maps.

On the basis of the data available to me, I am continually drawing different conclusions, even about the proportions of the Śiva temple. Therefore, although it is without any shadow of doubt that a particular system must underlie the complex, I will not go into this question here. In this matter not only diagrams but also the cosmological connections have to be taken into consideration: the whole complex is built as a terrace, in combination with the concentric walls and the rows of temples, which we shall discuss shortly. ${ }^{4} \mathrm{~A}$ third factor in the layout is the adherence to the older type of groupings in which temples face each other: main temple-subsidiary temple, main temple-three subsidiary temples, main temple-ancillary temples-subsidiary temples (three facing three).

The symmetrical plan is given particular expression in the area between the first (innermost) and second enclosing walls. On the terrain itself one is less aware of this because of the fact that a wall of candi stones has been piled up arbitrarily to form a fence around the complex as it now is. Moreover, with the exception of a few subsidiary temples now restored or in the process of restoration, it is one great pile of ruins. A better idea of the layout can be gained from the plan. The second enclosing wall is concentric to the first, but its sides each measure $222 \mathrm{~m}$. The area between them rises in terraces and in such a way that the subsidiary temples ( 6 by $6 \mathrm{~m}$, height $14 \mathrm{~m}$ ) located on these terraces form four

3 Heine-Geldern, Weltbild und Bauform in Südostasien. Wiener Beiträge Kunst und Kulturgeschichte Asiens (1930); Stella Kramrisch, The Hindu temple 1 (1946),

4 Heine-Geldern I.c. 
squares containing $68,60,52$, and 44 buildings respectively, thus making a total of 224. The Indonesian word used for these subsidiary temples is 'candi perwara', from perwara = lady-in-waiting. Very little indeed remains of the wall which once enclosed this unit. The two concentric squares themselves lie within a third enclosing wall with sides measuring $390 \mathrm{~m}$, now however inclining towards the southwest. The innermost squares are oriented purely according to the points of the compass with entrances in the axes of the four sides. The gateways in the third enclosing wall lay approximately in the continuation of the axes of the centre. The southern outermost gateway can still be seen in the southern part of the complex, not far from the entrance. As far as it is possible to do so, the innermost gates are being partially restored.

Among the more than 230 temples in the complex - which respect to sheer numbers it does not fall far short of its great counterpart Sewu - those so far restored are: the Śiva temple, the two ancillary temples [candi apit], the small corner and 'kelir' temples, all in the central area, one of the eastern auxiliary temples, and work is still being carried out on a second one in the northeast corner. There are trial reconstructions of the Brahmā and Vișnu temples located behind the actual temples themselves, but largely outside the walls to the southeast of the complex.

After this preliminary orientation, I will first draw attention to the main points in the more recent history of the complex. Very little can be said about the more ancient past: whereas people generally refer to the period of [King] Balitung (early 10th century) as the time of its foundation, there have recently been some who have spoken out in favour of an earlier dating. ${ }^{5}$ Now that so much more of the monument itself can be studied and much more has become known about Central Javanese buildings, it may become possible to establish some degree of certainty in these matters. I will not pursue this question further at the moment. Whatever the case may be, about $930 \mathrm{AD}$ the centre of Hindu-Javanese culture shifted to East Java, and the Central Javanese monuments fell into oblivion. The monuments deteriorated and were overgrown, which has perhaps had a fortunate effect in that, when the elevation of the temple collapsed, the lower sections were safely covered. If this had not happened, it seems to me unlikely that so much of the lower part of the building would have remained intact. This collapse is dated at around $1600^{6}$, but the date itself is not particularly important. I shall now present the more recent history in the form of an annotated chronological list.

5. See i.a. Stutterheim, De stichter der Prambanan-tempels. Djăwã 20 (1940), p. 218-233.

6. Krom. Inleiding I, p. 445 et seq. (after D. van Hinlopen Labberton. Diăwả 1. 1921. p. $\left.198 f_{4}\right)$ 
1733, 1744, 1746, the first reports of European visitors during the court journeys to Mataram. They found a large hill, from the summit of which protruded the pinnacles of the principal temple ruins. Some statues were still to be seen in some of the subsidiary chambers. These included Durgã, the Slender Maiden (Loro Jonggrang), who gave her name to the whole temple complex. The main chamber was still filled with rubble.

1805-1807, the first survey by the military engineer Cornelius.

1864. Prambanan was still 'a great round pile of stones'.

1885, Loro Jonggrang's most recent admirer, after the Raden Bandung of the legend, Ir. J.W. IJzerman, took pity on it and cleared out the temple chambers. His Beschrijving der oudheden, etc, was published in 1891. In some places the course of the two outermost walls could still be traced; the innermost was largely covered with earth but its course was fully visible. The three largest ruins formed saddle-shaped adjacent hills, the tops of which were higher than the floors of the temple gateways. The lower sections and the entrances to them were covered with rubble. This meant that IJzerman was still unable to obtain an overview of the real situation and thought it possible that the three main temples stood interconnected on a platform. Many of the facing temples had been demolished. The northern ancillary temple [candi apit] had almost completely disappeared. Of the southern one, little remained beyond the subbasement, the staircase, and part of the wall. ${ }^{7}$

1889 , more of the central area was cleared under the direction of Groneman, at which time all the loose stones behind the temples were thrown into piles: 'a large-scale archaeological murder', in Brandes' opinion.

1902-1903, Van Erp carried out the restoration of the subsidiary chambers of the main temple and compiled an important report of a technical nature.

19/8, after the completion of its successful reconstruction work in East Java, carried out according to the latest insights and methods, on the initiative of its head, Dr. F.D.K. Bosch, the Archaeological Service plunged itself into the sorting out of the stone dump at Prambanan, with P.J. Perquin in charge. The aim was to discover if it would be possible to partially reconstruct the façades. Throughout the years that follow the work continued, albeit with several interruptions, in fact until 1953 in the case of the Siva temple. Since 1921, however, both the working methods and the principle of reconstruction were subject to serious criticism both in Indonesia and in the Netherlands. Because of this, the Archaeological Service abandoned 'forever its ivory tower for the public stage'.

7 Besides IJzerman's Beschrijving see also Groneman, I.c. and Ind. Gids 1887, II p. 1431 et seq. 
1923, during a private visit to Indonesia Dr. H.P. Berlage gave his advice.

1924, an Advisory Commission for the Restoration of Hindu-Javanese Monuments was set up. Van Erp, who was presented with the means to visit Indonesia by a number of 'Friends of Asian Art' in the Netherlands, was a member of this advisory council, and his most recent report on the technical side of things (1926) is largely based on its confidential report.

1926, investigation of the area between the second and third (outermost) enclosing walls, directed by Stutterheim.

On the grounds of the 'mistakes, serious mistakes' which had been committed ${ }^{8}$ during the restoration of the Siva temple, the work is handed over in 1926 to B. de Haan, adjunct-inspector, later inspector, of works. Nonetheless, the principle of the reconstruction of cultural monuments, provided that this is carried out in a scientifically responsible fashion, was adopted by the Advisory Commission and since then has led to numerous important restorations in the form of reconstructions.

1927, a permanent Archaeological Commission intended to lend its support to the head of the Archaeological Service in architectural and cultural matters was set up. As the result of the improvement in the methods introduced after the 'restoration issue', however, it seems that there was less need for this support (= control?). The Commission quickly became dormant.

1930, B. de Haan died just at the moment that 'what the Prambanan Commission had considered impossible, was achieved, that, in particular, all the fragments of the main temple which were piled up on the ground had been put back into their original position, up to and including the uppermost section of the cornice' (that is to say in a trial construction). Research into the form of the roof sections was still being carried out. Since 1927 the material for the reconstruction of the two small ancillary temples [candi apit] was also being gathered. Between 1930 and 1933 these were reconstructed in their former glory.

193I, direction of the work was taken over by Ir. V.R. van Romondt, inspector of works. The work was continued with the collaboration of P.H, van Coolwijk, who assumed the day-to-day management of affairs for a time during the Depression, when Ir. van Romondt spent most of his time working as a teacher. During the last few years before the Second World War, it was above all the two Indonesian overseers, Soehamir and Samingoen, who worked on the temple, under the direction of the aforementioned persons.

1937, the essentials of the trial constructions were ready: thanks to the Welvaartsfonds (Welfare Funds), work could commence on the actual recon- 
struction of the whole temple, for which a total of eight years was estimated. The teak scaffolding alone required one year of this time.

1942, all the Dutch officials of the service were interned, and the work was continued by Messrs. Soehamir (until the beginning of 1949), Soewarno, and Samingoen, of whom the latter was now in charge of the day-to-day running of Prambanan.

At the time of the capitulation the temple had been built up as far as the uppermost sections of the cornice, although the definitive finishing off was not as far advanced. During the war years the reconstruction reached such a height that the scaffolding had to be raised. It was extremely difficult to find the cement and other materials required. However, for as long as possible, the work was continued, while at the same time an investigation was launched into the form of the Brahmâ and Vișnu temples. Later there was another investigation to check the possibility of restoring one or more of the subsidiary temples outside the first enclosing wall.

1948, the Second Police Action. A halt was called to all activities. A violent battle continued to rage around Prambanan; the office of the Architectural Section there was hit by shells and plundered, while the Siva temple also suffered shell damage.

Mid 1949, the work was taken up again by the Republican Archaeological Service.

Late 1950, both archaeological organizations (RIS/Federal Republic of Indonesia and RI) were once more placed under one director, and Ir, Van Romondt again assumed charge of the Architectural Section.

January 1952, the top was reached! This achievement was celebrated. A few months later the top was struck by lightning, which caused a serious delay in the completion. In the meantime the gateways and the crown of the balustrade were finished off.

20 December 1953, the work - the fruit of a magnificent collaboration - was complete. The temple was opened by the President of the Republic. ${ }^{y}$

Whenever a layman sees photographs of the Siva temple or of any other building before reconstruction, one question is always asked: Did people know what it looked like before work began? Were there old drawings of it? It can indeed be the case that old photos can help in restoration. De Haan, the restorer

9. For the fate which befell the Archaeological Service during and after the war: O.V. 1942-47; 1948, p. 20-41; Laporan tahunan Dinas Purbakala 1950, p. 10-21; Tijdschr. Bat. Gen. 83 (1949), p. 286-300; Indonesië 7 (1954), p. $481-513$ [Van Romondt]. For the history of the restoration e.g. Cultureel Nieuws Indonesiè (Sticusa) 1954, no. 36-37. 
of Candi Sewu, had at his disposal photos of the subsidiary temples taken by Van Kinsbergen during the last century, a few years before the earthquake which caused the collapse of the already dilapidated top. But this is a matter of details. Generally speaking it can be said that the result comes as a surprise even to the restorer, albeit a gradual one. Of course, one already has a broad concept of the general layout of a Central Javanese candi, but each individual temple has its own idiosyncratic form and peculiarities. One may never, even on paper, attempt to draw an analogy between the reconstruction of one building and that of another. The only proper way to go about matters is to try to gain an insight into the original form by feeling one's way and trying out the pieces of the building, and this indeed is the method employed by the Archaeological Service. ${ }^{10} \mathrm{It}$ is all a question of puzzling, fitting, and measuring, here and there three-dimensionally. The reason that this bears fruit is due to the fact that the Hindu-Javanese master mason did not work with stones of a standard size, like our bricks, and also thanks to the decoration, which spreads out over a large area of the surface. Each stone used for the building of the temple received its final dressing on the spot, and has the size and other idiosyncrasies which pertain to a special place in the walls; in other words, it fits there and nowhere else. The trick, then, is 'merely' to find among the multitude of stones the one that fits into that special place. This task was not made easier at Prambanan by the fact that many stones had been taken away, others had been redressed by the first restorer (something of course which is absolutely forbidden in restoration work), and in principle everything that was lying about loose was thrown together during the cleaning-up in 1889. Apart from this, one still has as a clue the place the stone was found: a stone which has fallen down will generally pertain to the face near which it is found. In this case one has to begin by sorting the stones from the dump according to size; a start had already been made on this in 1918. This was followed by the finer sifting, paying attention to the seams of the joints and the linking pieces, breaks, ornamental lines, and so forth. All this is work requiring enormous patience, accuracy, as well as a photographic memory for details - work at which Javanese overseers and craftsmen make themselves masters in the long run. This is one of the reasons that work of this kind did not grind to a halt during the worst of the Depression. Once one loses one's trained personnel, the battle has been lost. During the reconstruction of the Śiva temple, work was carried out by seasoned campaigners who had been carrying out similar work for decades. And even now, although the oldest of them have retired during the last few years, we come across people at Pram-

10) See Van Romondt, Djåwå 20 (1940), p. $234-239$ [this volume]; the same in Amerta I (1952) and Oriëntalie 46 (1954) (about Candi Gebang). 
banan who have spent nearly all their lives in the Archaeological Service.

The stones and fragments are then put together in a trial reconstruction, the pieces which are still missing being provisionally filled in with softer stone. In so doing the stone 'girdles' [sections] which, placed one on top of the other will form the temple, are gradually pieced together. For the time being they are then left next to each other, no higher than about four metres, at ground level. As time goes by it is possible to make a draft reconstruction from the trial construction. These were already available for the Śiva temple some years before the actual reconstruction was attempted in 1937." This excluded the possibility of there being any significant surprises, even though no one had been able to visualize the reality so vividly that the building, when finished, was not a revelation. ${ }^{12}$

In the work of replacing the trial constructions, the original state has to be recreated accurately stone by stone. On the other hand, care has to be taken that there is a proper relation between the stones and the core of stone or reinforced concrete behind them. Externally the old situation is restored, while internally a modern construction is applied. Naturally in the external work those stones which have not been found are replaced by new stones. This does not affect the genuineness of the whole, as long as this is where it stops. 'To conjure up' ornamentation or sculpture is out of the question, nor was this done. Our photograph (Photo p. 202) gives some impression of the way the restorers set to work. Missing stones have been replaced by smooth stone, ornamentation is only indicated in broad outline if the original pieces had been lost. Each new piece is marked as such by a lead tag and is accounted for on the detailed drawings by another colour than that used for the old stones. Disturbingly smooth new stone can still always, if necessary, be subjected to some roughening, and joints filled in in order to diminish the 'pock-marked' effect.

One realizes what a great acquisition the reconstruction is as soon as one puts the famous photos of former times next to ours or rereads Krom's description in Chapter 12 of his Inleiding. What a very small part of the temple was known in 1923 and how many uncertainties there still were about it. Krom only deals with the terrace, the balustrade, and the flights of stairs, the (second) sub-basement, the sections with the guardians of the points of the compass, the lowest part of the body of the temple, the images in the main and subsidiary chambers. Leafing through, our eye is caught by some words on page 470 :

II Djåwå 20, fig. 11 after p. 234 [see Van Romondt, this volume] and Amerta 1 (1952), p. 30 .

12 See the words cited in Indonesia by Van Romondt, I.c. p. 503-4. 


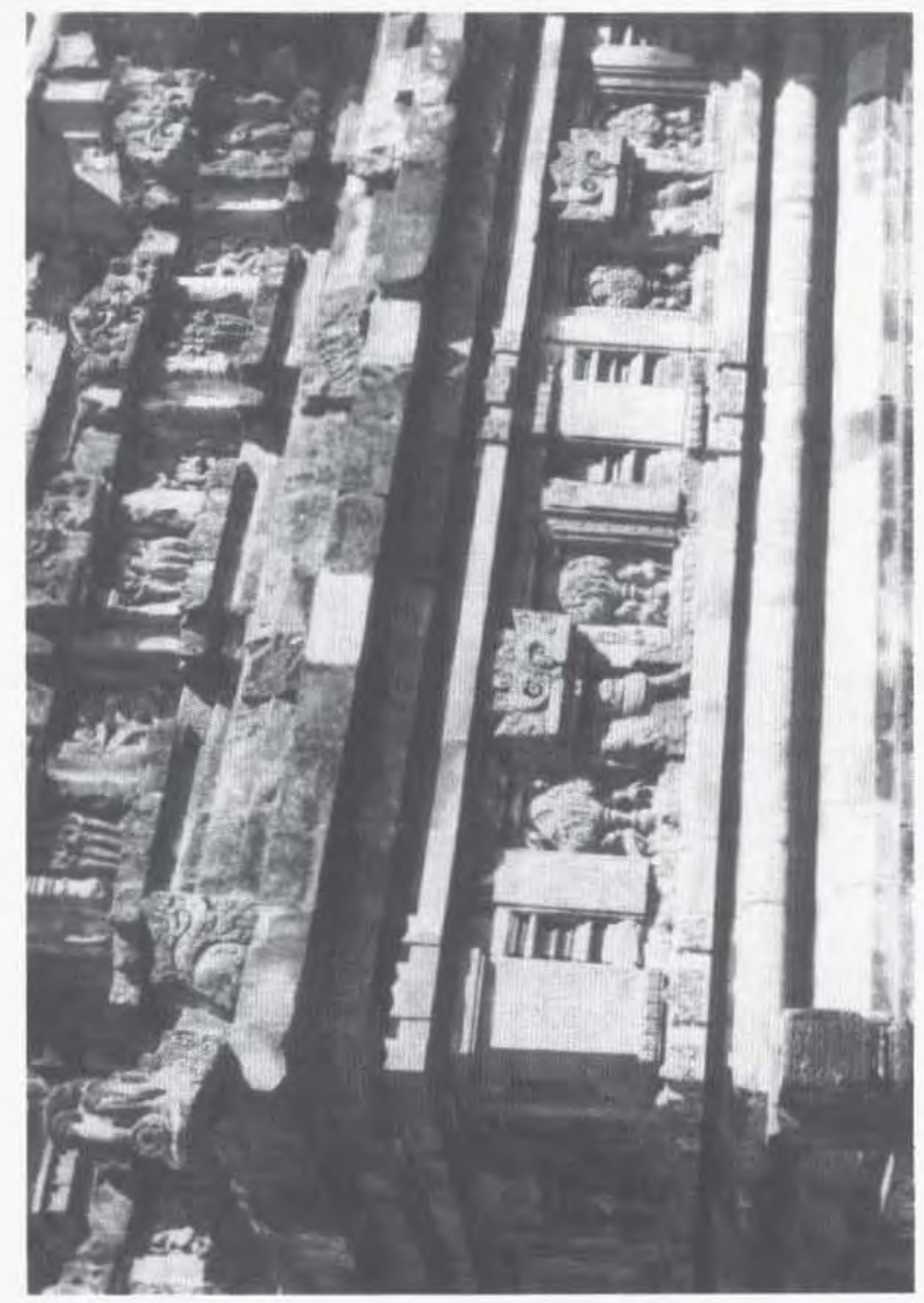

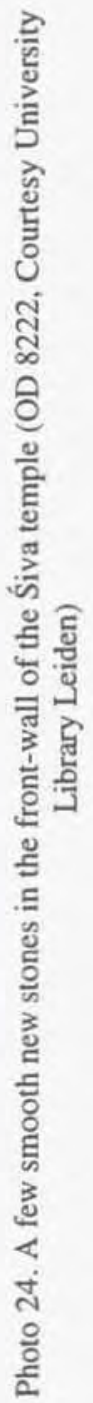


The actual course of the roof will [...] always remain a mystery, unless the pieces are found, which will provide the data for the reconstruction, among the fragments which hae been thrown away and then to sort them properly. Its construction will have been complicated, with projecting sections, cornices, and a series of small roof temples.' As our photos demonstrate, we have succeeded in reproducing the complicated shape of the roof. Now that we can see this tangibly and in absolute certainty before our eyes, we are entitled to speak of a wonder rather than a mystery. With reference to this certainty we can quote the words spoken by Van Romondt in 1940, words which were not vain claims but the formulation of a principle which was fully adhered to: 'no attempts at actual reconstruction were to be undertaken until there was absolute certainty that every authentic piece could be returned to its original location. Let it be emphatically stated here that now no single stone is replaced about which there is the slightest doubt; such a stone is set aside as unplaceable.'

Before we consider the Siva temple, let us first take a look at a simpler object: the better preserved of the two ancillary temples [candi apit] in the south. A good twenty years ago, after having long stood in ruins, both these temples once again became jewels of Central Javanese architecture. Even though the much larger main temple once again dominates the complex, these small buildings, about $16 \mathrm{~m}$ tall, still continue to attract attention. Both are of the same type. They are very slender buildings, due to the steep staircase and the doubling of the sub-basement, the high pinnacle of the fore-portal, and the sharply rising roof. The horizontal lines, which are ever-present here as elsewhere in Central Javanese art and given added emphasis by a central band running through the architrave, are interrupted and pushed into the background, especially in the superstructure, by the vertical flashes of the bell motifs with their slender pinnacle. ${ }^{13}$ Here, in simplified form, we find all sorts of things which can be found in the main temple: the 'Prambanan motif in the sub-basement, antefixes, and bells. In the main temple the fore-portal has been separated from the architrave and has been thrust forward on either side as an independent gateway building.

As regards the other ornamentation, at this point I shall only mention the fine miniature lions sculpted in the round next to the entrance and the staircase medallions with tendrils, which spring forth from the miniature lions in relief. Here the stringboards consist not of the usual kälas but of triangular decorative pieces. They terminate in makaras with human figures in their mouths, and one of them in a lion's head ending in a trunk. The 'Prambanan motif of the subbasement, to which we shall return in more detail at the main temple, lacks the panels with the tree of heaven which make it so attractive. Here and there the

13 Here and in the rest of the article, I use the terms superstructure, elevation, and roof, having the same meaning, to give some variation. 


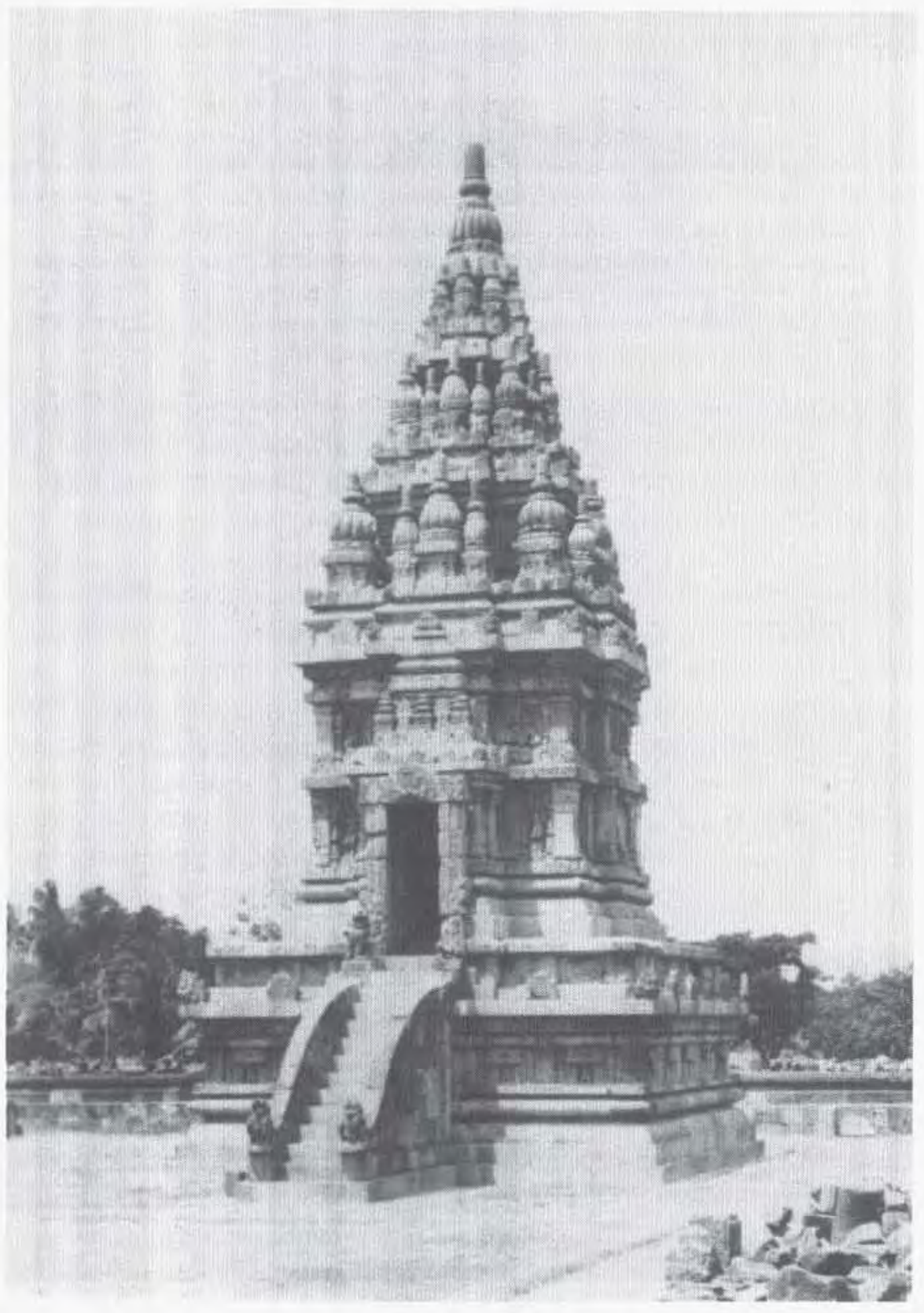

Photo 25. The southern 'court temple' (candi apit) (OD 11395, Courtesy Kern Institute Leiden) 
niches with the lions are separated by a smooth panel and two small pilasters with antefixes in the cornice which juts out above them. The vertical nature of these sections is reinforced by the large antefixes above the cornice of the subbasement, which to the eye appears to be a continuation of it. Although there is no balustrade which distracts the eye from the body of the temple as it does at the larger temples, which means that it has to be raised, the temple body is raised on a plinth with decorative panels. These seventeen panels display jewels, vases, and shells as centrepieces of a burgeoning of tendrils. Whereas the sub-basement and plinth have a rectangular plan, the parts of the superstructure above them and the sections of the roof have small protuberances on their four sides. The fore-portal is placed against the northern protuberance (of course in the case of the northern temple, this is the southern side). Above the middle section, which the ancillary temples [candi apit] and the subsidiary temples have in common with the Siva temple, the upper part of the architrave tends to recede. The façades are divided into twenty-two panels by the protuberances and the central section, each - if still intact - filled with a standing or, in the case of the central panels, a sitting figure. Even though the iconographic details show very little of special interest, I will give a list in the pradaksinā order:

bottom frieze: North 1, standing male figure with flower; East 2, idem with flower and leaf; 3 , seated female figure, on her right a book on a stalk, on her left a fly-whisk; 4, standing male figure with flower and leaf; 5 . broken; 6 , seated female figure, on her right a book on a lotus, left a damaged fly-whisk; 7 , male figure with utpala from the tuber, and an incense candle 14 beside him on his right; West 8 , female figure with fly-whisk; 9 , female figure with fly-whisk, wound around the stick like a spindle. 9 , broken, one hand in varamudra $; 10$, female figure with on her left an utpala, on which is a flower or a complicated jewel; North 11, male figure with a flower.

top frieze: North 1, kneeling female figure with flower and incense candle (wrapped in an embroidered cloth); East 2, kneeling female figure with a lotus bud; 3 , seated, broken; 4 , kneeling female with a lotus bud; South 5 , kneeling female with utpala; 6 , seated female, an utpala on her right, an ear of rice on her left; 7, kneeling female figure with an incense-burner and kipas; West 8 , female figure with utpala and half-burnt incense candle; 9 , female figure with utpala and fly-whisk or ear of grain; 10, kneeling female, damaged; North 11, kneeling figure with torch and flower.

The lower central figures are flanked by lions, as far as these have not been rendered unrecognizable through damage. The clothing of some of the female

14 A similar incense candle is also on Borobodur, Bb. - mon. pl. DB' 22, Vol. III [Krom 1931a]. 
figures is reminiscent of the peculiar style of dress of various women in the reliefs on the large temples. ${ }^{15}$

Nearly all the panels in the northern temple had to be rebuilt with smooth stone. Here it is only possible to note the lower central panel of the sides and the back: West, a seated six-armed figure, unfinished, foremost hands on the knees, the second pair folded together in front of the breast, the right hand of the furthermost pair holds a rosary, the left a fly-whisk; North, another six-armed figure, like the one just described but the furthermost pair of hands now holds a rosary and an axe; East, four-armed figure, right foremost: in front of breast (broken), left on the lap, right back: rosary, left: broken. All these figures are male.

Neither the northern nor the southern ancillary temple [candi apit] contains an image. The use to which these buildings were put is not clear.

The feature that strikes us most about these temples is the magnificent roof. The repeated combination of architrave, double cornice, and diadem of bells should be seen as a unity. This theme begins in the body of the temple itself, which on its double foundation of sub-basement and plinth forms the first part of a quadruple tower. We find the same combination of architrave-cornice(niches)-bells even lower, namely in the terrace on which the rest of the temple is raised. The encapsulation of the architrave and the pinnacle is also indicated in the Indian system, which considers that the pillar composed of the shaft and capital to which this can be compared forms one unit and gives it a name. At the Siva temple we shall find this unit of architrave-cornice-(niches)-bells clearly present in the terrace. As far as the roof is concerned, the way in which these units are fitted together to form an indivisible whole is easier to see in the ancillary temples [candi apit]. It goes without saying that the superstructure of the main temple follows a much more complicated plan. Nonetheless, the principle is the same. At the ancillary temples the first unit we see above the subbasement is the body of the temple-cornice-bells, then architrave-cornice-bells of the first storey of the roof, followed by the same again in the second roof storey. Within this highest diadem of bells the architrave again serves as the basis for the central bell, which takes the place of the diadems of the lower storeys. The sections of the body and the superstructure cannot at any point be clearly distinguished from each other by a horizontal field, which would be the case with cubes placed one on top of the other. This would only be possible if we were to remove the bells ${ }^{15}$, but these are an organic part of the architecture

15 Including Stutterheim, Rāma-Legenden und Rāma-Reliefs (1925), pl. 37, 50, 57, and Photographs O.D. 7325 (Krishna Series).

16 Compare the schematic construction of Kalasan by Professor Van Romondt, which I 
and are indispensable. And these bells are the precise reason that each section fits into the one preceding: each block that forms the architrave of a new set of architrave-cornice-bells is contained within the diadem of bells of the former set. Taken as a whole it has the nature of a telescope, of which one tube fits into the other. In English it is possible to use the word 'telescoping' for this, meaning 'to slide, fit, or come together like a collapsable telescope'. I prefer to see the candi as an extended rather than a folded-up telescope, because the upward thrust is betrayed in every detail. The essential thing is that we see the building as a single organic composition of parts. This is the way in which it has been composed, using architectural and ornamental means. The telescopic element plays a very important role in this.

Terminologically speaking it is difficult to make a rigid distinction between the body of the temple and the superstructure. In the superstructure one can call the first repetition of the temple architrave storey I, the following II and so on. In my own notes I use the term storey 0 for the first diadem of bells, in particular if this is extended by a ring of niches as in the Śiva temple, preferring to consider this as zero or an '(o)vergangsetage' [transitional storey]. This emphasizes its function, which is to join the temple body and the superstructure, and its ambivalent position between these two sections of the building.

In the trial reconstruction of the Śiva temple the superstructure of course had to be divided up into practicable horizontal bands which were not too high. These were composed of one storey per time with the bells pertaining to the same level. However, these were not organic sections of the building but mere cross-sections, created by cutting transversely through a set of architravecornice-bells. When the building is viewed as a whole, we have to ignore this division into bands. The temple is a whole, in which each part organically fits in with the other. As far as this detail is concerned, the cornice with its reduplication and diadem of bells forms the upper culmination of the body of the temple, but at the same time the bells (plus the band of niches) create a firm transition to the next part of the building: the first repetition of the temple body (and so forth) in the upper section, on top of which other repetitions will follow. As is customary in Central Javanese architecture, here the master mason has once again rendered whole, what he had first divided. ${ }^{17}$ This unity is achieved above all in the plastic ornamentation. Here we see something which has often

was fortunate to be able to use in my booklet Kalasan dan Sari (Seri Tjandi 1), published by Penerbitan dan Balai Buku Indonesia (= Moderne Boekhandel), 1954, p. 5.

17 See Kalasan dan Sari (1954). 
been remarked on before: Indian and Hindu-Javanese architecture is plastic to a certain degree..$^{18}$

In these temples, moreover, we can see something which is also valid for Borobodur, that there is both an internal and an external form. At Borobodur the internal form is a sort of amputated terrace pyramid consisting of a rectangular substructure and a circular superstructure. This is Borobodur as we know it from the plan, cross-sections, and aerial photographs. But beginning with the ground floor, the unity presents itself to us as a segment of a sphere, albeit merely suggested. This is the result of the plastic ornamentation of the terraces and of the interrupted contour line of the 'pyramid', which unite to make the silhouette a segment of a circle, thus creating the impression that in Borobodur we are seeing the segment of a sphere. ${ }^{19}$ The original form of a stüpa, a hemisphere or segment of a sphere, has been combined with the building of terraces in such a sophisticated way that this has become nearly as important for the stūpa in the course of its history. Nor must we forget a number of other accessories for the stüpa, which we must leave aside for the moment.

Among the Prambanan temples the pyramid form also plays a role in the internal plan, in this case as a slender tower-like step-pyramid. The external form is lightly sketched around this by the slightly curved and tapering contour line. At this point it is useful to forget the ornamentation for a moment and attempt to see just the masses in their block piles, keeping in mind that this is just one aspect of the building and that it only becomes reality in combination with its external form. We then find a building that is above all reminiscent of rare temple types like the two prãsãdas on the island of Serangan off South Bali20, which more or less link up with the Sat Mahal Pãsãda at Polonnaruwa (Sri Lanka) and Wat Kukut (Thailand): bare, self-regenerating block towers. ${ }^{21}$

The Serang prāsaadas and the Sat Mahal Pasada are solid. The latter is thought to be a representation of Meru, which we assume is also the case for the first two mentioned. One could say this was perfectly natural, because we may also see temples of different types as replicas of Meru in various forms. The most global division of these forms is in temples in India with horizontal roof storeys, piled up one on top of the other like terrace pyramids, and temples with high roof towers (sikharas, even though this is used with another meaning), which

18 Cohn, Indische Plastik (1921); With, Java 2nd imp. (1921); Kramrisch, The Hindu temple, p. 183 et seq.

i9 Cf. Van Erp, Barabadur-mon. II (1931), p. 411 and Mus, Barabadur (1935).

20. Antiquities of Bali, also in the Tjandi Series, in the press (Bali Purbakala, 1955).

21 Rowland, The art and architecture of India (1953), pl, 142 B and 171; Paranavitana, The stūpa in Ceylon (1947), p. 98 et seq., pl. XXI. Stella Kramrisch also mentions the Sat Mahal Pasada in a similar connection. 
soar on high, borne on their slightly curved contours. In India this latter feature is found mainly in the northern areas (for instance in Bhubaneśvara and Khajuraho). ${ }^{22}$ The meticulous sections, which make some buildings reminiscent of corn cobs, and the sometimes profuse decoration do not detract from the general lines of the contours. Strong horizontal sections of the superstructure are especially prevalent in South India. Each storey of the roof carries a diadem of roof turrets, in principle small replicas of the temple itself, square at the corners, rectangular along the sides. Occasionally they seem like a railing of small buildings along the edge of the storey of the roof, sometimes they move in closer to the mass of the roof. The northern sikhara temples sometimes have a repetition or replica of the temple itself against the tower, but in this case not attached to one particular storey - they in fact do not have a division into storeys in the same way the southern temples do - but soar up, sometimes like a rocket shooting up over large distances along the line of the roof tower, against which they nestle snuggly. The tower is crowned with an incised cushion (ämalaka), the top of which is formed by a tapering finial (stüpi or stüpika). Each of the auxiliary sikhara is similarly crowned with an ämalaka, which characterizes them as sikhara replicas.

One only has to leaf through a book of photographs of Indian temples to be immediately struck by the multitude of forms which this global design can assume. There is a plethora of combinations, both in India itself and outside it everywhere, including Java, where the elements of Indian architecture have been developed. One of the Indian variations, a combination of South Indian and North Indian, retaining this easy but disputable division, is as follows: the superstructure is divided into clearly horizontal sections, which correspond neither with the small layers of the North nor with the storeys of the South. Each time, a group of three sections is characterized as one cohesive set by putting an ämalaka at the corners of the third layer. This is repeated a number of times until one great ãmalaka forms the finial, ${ }^{23}$

In the case of Java, in the Diëng temples of the ordinary type we find clearly marked roof storeys, decorated at the corners with roof turrets. Candi Bima, which is also located on Diëng, displays a completely different design. It also contains horizontal sections, but these are not in the form of storeys. Each of the sections is decorated with niches, filled with heads or vases, and at the true

22 See, for instance, Coomaraswamy, History of Indian and Indonesian art (1927), fig. 214 et seq., for the South Indian temples, ibidem fig. 202 et seq.: Rowland, 1.c. pl. 103, 106. 112 et seg. See also Kramrisch, I.c. and Jeannine Auboyer, Arts et styles de I'Inde (1951).

23 Rowland, I.c. pl. 76 (Aihole), 102 A (Pattadakal), 103 A (Bhubaneśvara: Parasurầmešvara temple). 
corners in the second niche is a jewel. The niches with heads are reminiscent of the kudus of India: horseshoe-shaped arches containing heads, reminiscent of the 'observers' of ancient Indian art who look out of windows. In India these have become purely ornamental; in Java we find them again and again as filling for antefixes. As each section has a frieze of niches, the division of the superstructure into horizontal blocks is accentuated. Krom introduces this in disagreeing with Uzerman who, seeking correspondences with the Calukya architecture of India, tended to be more impressed by the high soaring roof. Both these views are right. What the upper part of the crown of the temple was like remains unknown; however, it can be assumed on the basis of the incised cushions (ämalakas) on top of the double set of niches at the true corners. The finial will also have been furnished with such a cushion on top of another few sections. In fact, the niches topped with ämalakas are precisely the most interesting part of the pinnacle of the temple: two sections with an amalaka on the corner of the third. This is just like the mixed type we spoke of earlier, but now even more strikingly influenced by the storeyed style in which a frieze of niches or or roof turrets is placed on each storey. This is what gives Candi Bima its somewhat ambivalent character, setting it apart in a category of its own. ${ }^{24}$ While other Central Javanese roof forms, in particular here at Prambanan, show a combination of various elements and types, the solution at Bima is markedly different from this, and although fascinating, is less flexible.

After this digression let us return to Prambanan. The 'bells', as I have been calling them, are often described as ghantā (bell) or as ratna (jewel). Their general shape is strongly reminiscent of the stüpas which we find, for example, in the superstructure of Kalasan. Beginning with the fact that they are set on a socle ${ }^{25}$, I have the impression that in these beautiful decorative pieces we can find the memory of more than one sort of ancient roof ornament. This is expressed not only in the shape, but also in the placement. In the first instance, one could speak of a blending of the stüpa form of Kalasan and elsewhere, even without calling specifically Buddhist associations to mind, with the incised ornamental cushions, the àmalaka, of India. Should one so wish, one could also embellish them with jewel shapes. As variants of ãmalaka, the bells would be most appropriate in the finial and at the true corners, the designated location for these ornamental cushions. If they were only found at these places, we could easily think of them as ämalaka, albeit in a blended form. However, they are also situated along the sides of the projecting pieces; at the main temples in elegant

24 Stutterheim, Culnurgeschiedenis van Java in beeld (1926), pl. 9; R.O.C, 1902, p, 16 et seq., pl. 9-11; Uzerman, Album Kern (1903), p. 287 el seq.; Krom, Inleiding I, p. 186.

25 Kalasan dan Sari, fig. 16. 
groups of three with the accent on the one in the centre, at the Siva temple one next to each other. On the bases of the superstructures of the main and ancillary temples [candi apit] they form circles. In their placement the bells correspond here to the miniature temple replicas - small roof turrets of the South Indian temple styles - but, from the point of view of their form, they are once again incised āmalakas. Without letting myself be distracted by the terminology used, I believe we can conclude from the foregoing that, not only in relation to the great plan of the temple superstructures (building up in storeys combined with sikhara contours) but also in the details of the ornamentation (ãmalaka forms combined with traditional placement of roof turrets) we are dealing with a contamination, or, let us say, a synthesis, of a number of architectural styles and building elements. Here there is no academic imitation of an example or a prescription, but rather the creation of new forms from a richly diversified treasure trove of traditions and, perhaps, of personal observation of buildings in other places, even in India itself. ${ }^{26}$

The principle of repeating certain important elements in miniature, whether in the general shape of the temple or, in the case of the more highly placed total superstructure, in the bell-shaped decorative pieces, should be given proper attention. We find it in yet another form at Borobodur with the repetition of the main form of the (external) stüpa, but even more clearly in the main stüpa, in the open-work dagobs on the circular terraces and the innumerable stūpa decorative pieces of the niches and the gates. One could see it, storey by storey, as the increasing concentration of the great form via the roof towers up to the final crown, the quintessence of all - Kramisch speaks of the High Temple - or equally as an almost spasmodic expansion of the central top and nucleus into the great design. Whereas Borobodur seems to pulsate with counterflowing upwards and downwards movements over its entire surface, at Prambanan it is the upward line which predominates. Everything in the crown of the temples points upwards, like the uplifting of the substructure by the reduplication, the lofty placement of the statue of Siva in the main temple, in fact every accent exudes an upwards thrusting and pushing forth from the earthly to the celestial.

We now make a 90-degree turn, from the ancillary temple [candi apit], $16 \mathrm{~m}$ high, to the main temple, almost three times higher $(47 \mathrm{~m})$. In part it consists of the same elements, but much richer, more massive and powerful. Here again is the same upwardly rising character, section upon section. This is seen to best advantage when we stand opposite one of the true corners of the base. Earlier, on the reconstruction drawing [see Van Romondt, this volume], we saw it from

26 Cf. Bosch, 'Local genius' en Oud-Javaanse kunst, Med. K.N. Akad. Wet, afd. Lett. N.R. 15: 1 (1952), p. 20 et seq. 
directly in front, and without any difference of depth between the gable fields drawn one next to the other. This gave the effect of a fairly wide building. During recent years, as more of the scaffolding disappeared, giving an ever less obstructed view of the temple, it has become increasingly obvious how tall this building really is. From the bridge over the Opak near Prambanan one already had a wonderful glimpse of the complex from the south-west. Now, of course, this is much improved.

As far as the lower regions are concerned, the design is not a great deal more complicated than that of Candi Kalasan. It is considerably simpler than the main temple at Sewu. Shorn of the plastic and figurative ornamentation which is the source of its greatest richness, it is also relatively simple in the vertical construction. The ground-plan consists of a square with sides of about $30 \mathrm{~m}$ containing broad projections in the direction of the cardinal points. The distance from the true corners to the beginning of each projection is equal to the depth of the projection, which simultaneously serves as the 'modulus' for the proportions within the monument. ${ }^{27}$ The same twenty-angle plan is repeated in all the horizontal sections up to and including the final section, right under the large bell which forms the finial, in other words up to and including the 'skandha' (shoulder) of the superstructure. In the top part of the temple, however, the true corners in each succeeding storey recede more sharply than the projections. By contrast, these projections become increasingly narrow, the result being that the plan of the upper storeys increasingly assumes the character of an equal-armed cross with the angles of a small square between the arms. The contours of the top of the temple, that is to say the sikhara character of the 'external' temple, is therefore primarily determined by the course of the projections. In the temple body itself the façades of the projections in conjunction with the ornamental framework of the entrances to the chambers (including the porch) are also much more important than the sixteen other vertical panels of the façade fields.

The vertical construction contains a terrace or first sub-basement; a second sub-basement as the basis for the temple body; then the temple body itself crowned by a girdle of niches topped with a diadem of bells, which one could designate roof storey 0 but which fits in equally with the architrave below it; four successive roof storeys, each one adorned by its crown of bells; and finally the magisterial bell as the highest culmination and top piece of the whole structure. The danger that the building might seem top-heavy to the spectator is avoided by the broad plan of the terrace and the rich ornamentation on it.

The staircases, which lead to the upper part of the terrace, emerge from the 
midst of the projections on all four sides. We have already spoken of the corner turrets alongside these in connection with the geometrical centre of the site. With the exception of the so-called 'candi pusat', which encompasses this centre point, they are all solid. The two sides which are not against either the sub-basement or the staircase are decorated with niches for figures in relief. It seems that these are all male, with utpalas or other flowers, sometimes crowned with a jewel. One has a jewel placed to the right and left of its feet. The form of these constructions, especially that of the 'candi pusat', which is open at the front, corresponds to the kelir and small corner temples, which form the magical border of the site. These, in their turn, are reminiscent of the well-known Balinese offering niches, in which offerings are placed in the house-compound each morning and evening.

The eastern staircase, which leads ultimately to the main chamber and thus forms the most important entrance to the temple, is wider than the other three. Originally this was not the case, however, because an older staircase has been found inside the present one which has the same measurements as those of the subsidiary chambers. In this part a change was effected in the plan during the building of the temple. There has also been a widening of the staircase by the southern ancillary temple. ${ }^{2 x}$ The staircase bays are decorated with a particularly fine tendril motif, springing forth from a pear-shaped jewel. At the ancillary temples the point of origin, as said, is a lion, which is likewise the case in the Brahmã and Viṣnu temples. The staircase bays of A and B have been left unadorned, while that of the Nandi temple has an elephant wearing a bell. The rebuilt subsidiary temple is decorated at this juncture with a round-eared hare; on a few others we find deer, and in one instance a monkey.

The makaras on the staircases are also not always the same. At the Śiva temple, the trunk transforms into a lion's head and there is a small lion in the jaws. At the other temples, the lion's-head trunk is indeed present, but the small lion in the jaws is replaced by a human figure, which appears at the halfway point. The makaras at the Siva temple rest on moulded socles, whereas those at the Brahmā and Viṣnu temples have a gana on the front of the base and a kneeling elephant on the sides. In the case of $\mathrm{A}$, the makaras have remained unworked blocks of stone, while at B there is no trace of them. The makaras in the subsidiary temples have an ordinary trunk with a lotus against it and a human figure in the jaws.

In conjunction the makaras below and the lions' heads above the stringboards form a variation of the combination käla-makara. This is also the case with the spouts on the cornice of the sub-basement of the Siva temple: a käla 
head with a makara thrust into its jaws. These spouts are the only form of drainage channels which can be found throughout the entire temple.

In his Inleiding Krom has discussed at some length the ornament Van Erp dubbed the 'Prambanan motif', which is found repeated thirty-two times on the walls of the terrace and is also found on the other large temples. Although it is no more beautiful at the main temple than anywhere else, it is always a joy to behold the wonderful trees of heaven and the witty animal figures beside them: rams, peacocks, monkeys, deer, and once again the round-eared hares we just mentioned - precursors of the animal-with-the-flap-ears of East Java - and by no means overlooking the denizens of heaven, the kinnaras, which are still idiosyncratic here. Compared with these, the lions in their niches are stiff and devoid of life, much less successful than their confreres at the entrance to the southern ancillary temple [candi apit]. The crown of the niche consists of a motif of thick tendrils and scrolls, which reverts to the käla-makara of the type that we find on the niches on the façade of Kalasan. There it is a käla head with short arms, bent inwards, terminating in makaras. The sculptor was apparently so unused to these inward-turning makaras, which are so rarely found in Java, that he set a strongly ribbed copy which turned outwards on the outside of each of them. ${ }^{29}$ Although at Kalasan many parts of the motif have transmogrified into vegetation, the animal forms and the inward-turning makaras also obviously held their own. In the case of the Prambanan motif the opposite is true: here the käla head has become completely vegetable. In the antefixes of the cornice above them we once more come across a similar motif. Here the kāla head has become a pear-shaped (jewel-form) ornament, flanked by ribbed makaras. Alongside the ribbed arms on the outside have been placed animaltype and once again ribbed makaras. The uppermost part of the motif presents itself as a miniaturized repetition of the lowermost.

The outside of the balustrade up on the terrace - likewise the decorative top of the wall of the terrace, just as the balustrades at Borobodur are at the same time the tops of the main walls below - presents a seventy-fold repetition of one single motif: a niche with groups of gandharvas and apsaras. Above each of these niches is an incised bell. In view of the fact that on the projecting corners two of the niches are covered by one bell, and by contrast there are bells without niches at the receding corners, the number of these finials is 66 , namely $2 \times 17$ and $2 \times 16$. There are in fact two fewer niches on the front façade because of the side chambers which flank the entrance gate. The Mahākāla (s.) and Nandiśvara (n.), which were located in the main chamber before the restoration of the gateway, are now placed in these side chambers. 
Between the niches, the balustrade recedes sharply inwards. The casements thus formed are filled with groups of figures dancing and making music carved in high relief. At twice the height of a man above the ground floor, they attract much less attention than would otherwise certainly have been their lot. Photos taken before the war give an excellent impression of these wonderful figures, whose sinuous attitudes are strongly reminiscent of Indian dance and dance reliefs. Choreographic and iconographic research has demonstrated that it is absolutely certain that the location of the figures follows a plan. During the first attempts to restore the temple in 1918 and thereafter, the niche reliefs and the intervening pieces were replaced arbitrarily, sometimes even being made to fit by hacking off undesirable projections on the sides. Furthermore, no record was kept of the position of the reliefs, which were still in their original positions when work commenced. This caused enormous difficulties in the reconstruction. which were overcome as expertly as possible, but not with $100 \%$ certainty. It was not always possible to take a lead from architectural indications; sometimes the choreographic data had to be used, or one simply had to rely on considerations of the symmetry of the architecture. Of the 62 dance panels, 21 could be replaced with absolute certainty, often on the basis of the old photos. The restorer of this part, Mr. Soehamir, had this to say about the choreographic data. The dance depicted on the relief corresponds to the Tandava dance of Śiva as this is described in the Nätyaśāstra. 108 figures, grouped in 32 series, are treated. The 32 dance panels at Prambanan - augmented by the two which had to cede ground in connection with the flanking-shrines next to the gate offered the opportunity to depict eight of these arigahâras or series of figures (poses) on, on average, two panels a time in each of the quadrants between two gates. The northeast quadrant contains more musicians and dancers. Moreover, the fine thing about them is that, just as with certain figures at Candi Sari, we are confronted not with fossilized dance poses but with a figure that is 'moving', flowing over from one attitude to another ${ }^{30}$ Despite all the precautions and research, there could be no guarantee of certainty when these panels were replaced. However, it is possible to speak of a high degree of probability. Provided that it is properly documented and explained sometime in the near future, this is acceptable, even though, compared to the reconstruction as a whole, this detail of the work remains less than satisfactory as far as certainty is concerned. No blame can be attached to the recent restorers, as the fault lies in the past. ${ }^{31}$

\footnotetext{
30 Kalasan dan Sari p. 21.

3 Van Erp, Verslag Commissie Advies Restauratie (1926), Bijl. (Append.) p. 6, 10-11;

O.V. 1937, p. 6; 1938, p. 7 with corr. 1939, p. 9 and n; Sochamir, O.V. 1948, p. 25-26.
} 


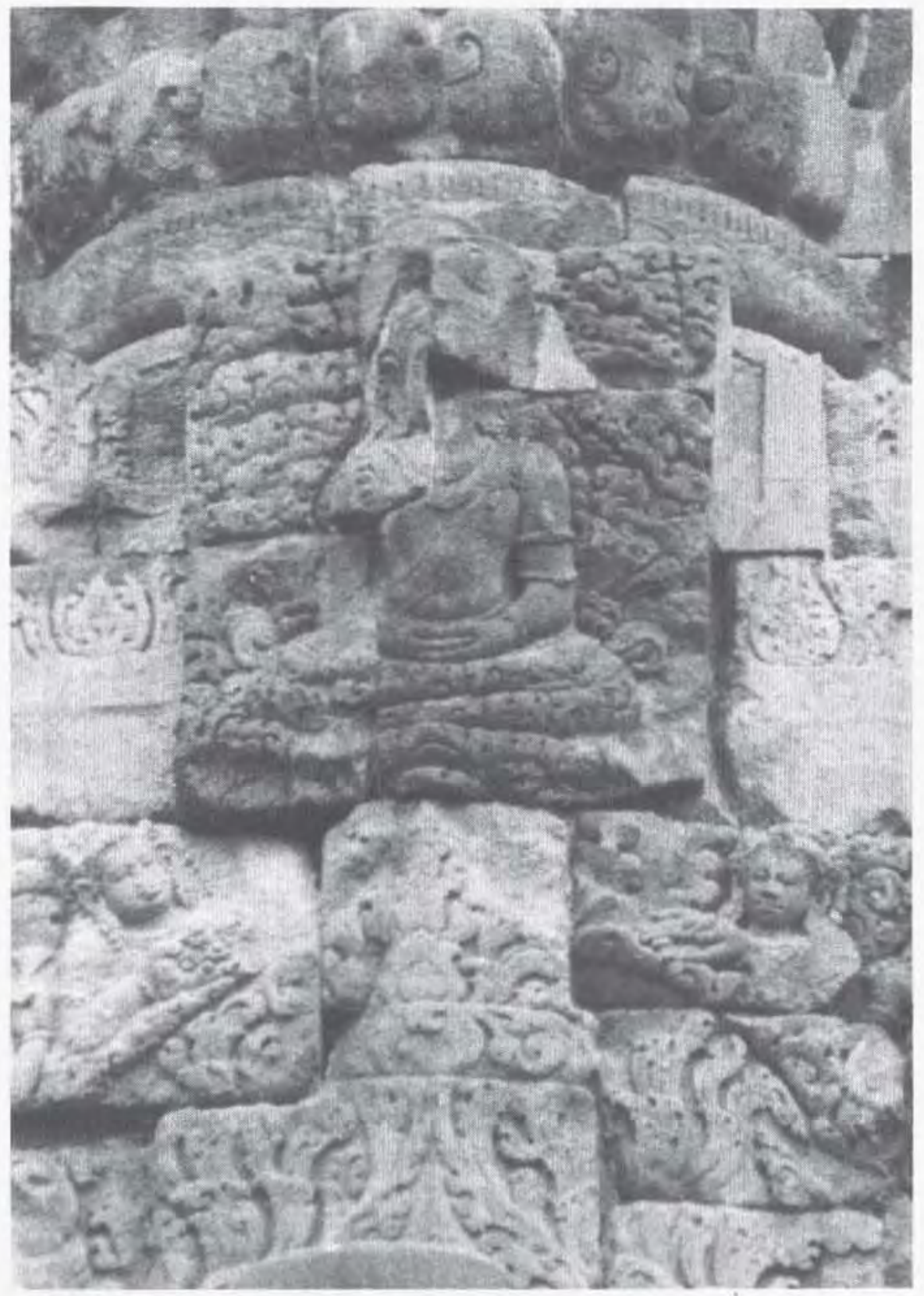

Photo 26. Still unidentified statue on top of the Kāla head. The statue may represent a Nāga. These are sometimes portrayed as half-man and half-snake, the top half being the torso of a man, the lower half a coiled snake (Stutley and Stutley 1977:198). Nāga are associated with clouds, rain and water, but also with the underworld (Kern 1916). [Photograph Roy E. Jordaan.] 
The inner side of the balustrade is decorated with the famous Ramāyana reliefs (up to and including the crossing to Lankāa). The continuation can be found on the Brahmã temple. While the series on the Śiva temple has become widely known from the photographic works of Groneman, Stutterheim, and Kats, very little at all of the sequel has ever been published apart from a few old photos of loose fragments. The same can be said of the very interesting series depicting the youthful adventures of Kṛșna, revealed to us on the Vișnu temple. Although both series are more or less provisionally set up at the temples mentioned, there are still a number of problems that have not yet been satisfactorily resolved either on the basis of the architectural indications or by comparison with texts or series in India.

The body of the temple contains the main chamber and four subsidiary chambers, of which the eastern one serves as the front entrance. The eastern façade also stands out because of the higher entrance and a number of details in the ornamentation. Moreover, here, just as at Kalasan, the plan is completely symmetrical quadrilaterally. The projecting fore-portals, which are found among the more simply conceived temples, for instance those of the ancillary temples [candi apit], are here placed opposite each of the entrances as discrete porches in the balustrade. The käla head kept level with the surface of the lintel is flanked by makaras, but the doorposts also have a makara ornament at their base, resting on a panel with a gana (one with a largish, the other with a smaller bell around the neck), a second with a käla, and finally a pilaster. The roof of the porch resembles those of the subsidiary temples, but higher and more intricate. In both cases the shape of the top as a whole and of the horizontally indented roof turrets are more angular than those of either the Śiva temple or the ancillary temples. As far as the superstructures of the temples are concerned, there is a certain unifying rhythm in the complex: the large temples and the ancillary temples reflect the supple form of the sikhara in their contours and rounded ornamentation, while the porches of the Siva temple, the porches of the ancillary temples, the corner turrets beside the staircases, the kelir and small corner temples in the central area, and the subsidiary temples all display the angular type. The ornamental pieces there are set horizontally, whereas those in the sikharas (the incised bells) are vertical. The lower regions of the temples and of the subsidiary temples therefore display a less rising type than those of the higher buildings. The obliquely rising sides of the roof contour burst is interrupted by a rapid succession of horizontal lines, large and small, in the former, whereas in the latter the vertical tendency drives through the horizontality of the storeyed structure.

Once we have passed through the gateway, we find ourselves on a landing, from which to the left and right small steps lead via small doors to the gallery 


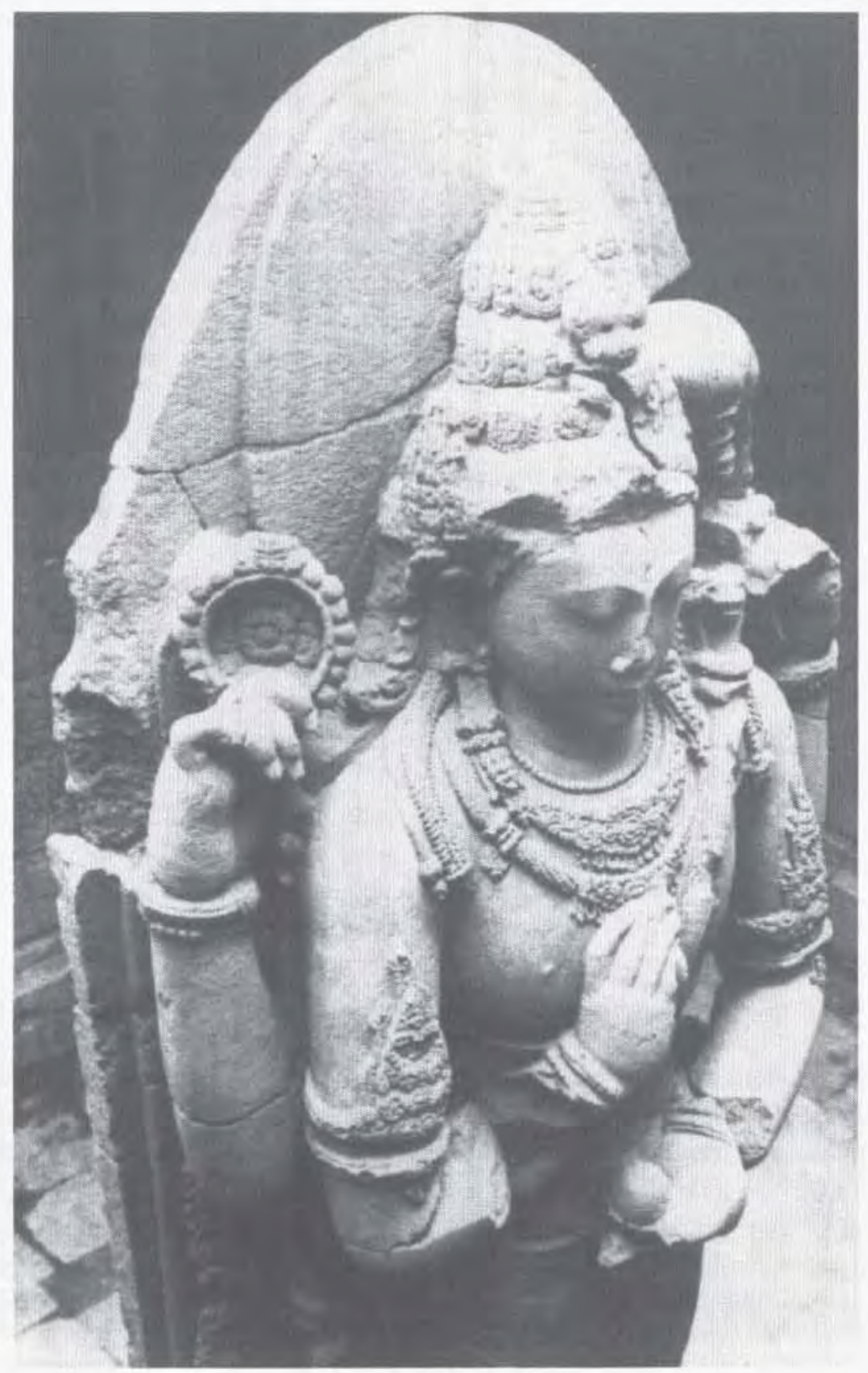

Photo 27. The statue of Śiva Mahãdeva (reproduced from Bernet Kempers 1955) 
and directly in front a higher staircase leads to the subsidiary chamber, or rather the porch to the main chamber. A magnificent käla-makara ornament frames each of the entrances: a tremendous head, jutting out strongly, left and right transmogrifying into a lion with paw raised menacingly. Just as those above the niches in the body of the temple, the kāla here is crowned by a relief of the superstructure of the temple; here the Leitmotiv of the superstructure, the incised triple bells (compare the top of the ancillary temples [candi apit]), forms the culmination of the door frame. Between the lintel and the käla head there are deities sculptured in relief; on the eastern side a four-armed god, flanked by two female companions (see Photo p. 50). Here, in contrast to the other façades, there is a deity set above the kăla head against a background of clouds (see Photo p. 218). On the western side the ruling deity is female. Two bearded dwellers of heaven float alongside the quiff of the kāla on the northern side; in the west and south these are ordinary heavenly beings, while those in the south are of a smaller type. The makaras of the doorposts here rest on square panels placed one on top of the other: the lower one shows a lotus rosette, the upper a lion with a rider.

I shall not enter into any discussion on the important decoration on the base of the temple body: the lotus vase motif on the plinth, 24 large panels with cosmological figures and their followers on the central part of the classical section. The same holds true for the well-known statues in the subsidiary chambers. During the restoration a few more fragments of the statue of Siva were found and replaced. A number of photos of this most sacred part of the complex were taken from a high vantage point. Although of course it was never the sculptor's intention that his statue should be viewed from this angle, it nonetheless reveals certain details to advantage. The majesty of the Great God viewed from on high gives way to something more endearing, almost childlike, which is far from obvious in the view from the ground floor. The photo reproduced here [Photo 16] is different from the one which has so often been taken in the last few years from the same position on the scaffolding.

After the restoration, once again, as of old, the central chamber of the temple is enshrouded in twilight, for the first time since the top of the temple collapsed centuries ago. The ceiling is made of reinforced concrete and the interior of the superstructure - of the whole of the structure, in fact - is also a modern construction. In order to lessen the pressure from the colossal mass of stones, three auxiliary vaults have been built into it one above the other, the topmost of them continuing into the pinnacle. ${ }^{32}$ The pinnacle itself rests on a pillar of reinforced concrete. One would perhaps be justified in asking if it was all this ironwork 
which caused lightning to strike the top in 1952. Just recently I was reading somewhere that the Meterological Institute thought it highly improbable that candi would be struck by lightning (this was in connection with Candi Jawi. which is presumed to have been struck by lightning in ancient times and then rebuilt). Experience shows otherwise, even in buildings in which no steel has been used. The ruins of the main temple of Sewu were also struck by lightning. at which time one of the makaras on the throne in the main chamber was damaged. Recently one of the subsidiary temples at Plaosan and the top of Borobodur (1953) fell victim. Whatever the truth, for the moment the Siva temple has been provided with a number of lightning conductors.

Above the cornice of the (second) sub-basement with the panels of the guardians of the points of the compass, or whatever we may call them, is the beginning of the footwork of the temple body: a two-part plinth, smooth ogive, smooth semi-circular, followed once again by smooth ogive. This time it has been sculpted as a lotus cushion, thus allowing it the honour of carrying its Indian name 'padma'. Above this is another semi-circle, this time decorated with an ovolo moulding - in short, a heavy reduplication of the normal frame. Once again there is a hint in the direction of East Javanese art in the way in which the frames have been treated.

The high architrave of the temple body is divided horizontally into two equal halves by a central band or intermediate frame. We have already come across this at the ancillary temples, possibly in analogy with the main temple. Elsewhere in Central Java, in connection with the internal division into two storeys, we see this reflected in the external design at Sari and Plaosan. In East Java this middle band becomes the rule. Outside Java we find this two-part division of the architrave in the manner of Prambanan at the great temple of Tanjore in South India. ${ }^{33}$ The band at Prambanan is interrupted in the middle of the projections by the crowning of the entrances. Each of the two times twentyfour façade fields formed by this division of the architrave contains a small niche, in which there must once have stood a statue. Neither here, nor in the girdle of niches above the cornice, nor in the central part of the pinnacle, could any statues be replaced. Finding one here and there in situ may well have made this possible but then only in the bottommost frieze of niches, because all the rest had collapsed and had first to rediscovered by the rebuilding.

The central band is livened up by antefixes: kälas on the projecting corners, with framed jewels between them. The decoration of the cornice of the temple body is the same, but on a larger scale (with framed heads in the antefixes) as 
was earlier the case with those of the (second) sub-basement. In the latter case the kälas in the corner antefixes are flanked by makaras.

The pilasters in the recessive and projecting corners, both above and below the middle band, are divided yet again into two. As the result of all these cuts in its height, the character of the temple body is much less lofty than that of Kalasan, where the niches utilize the full height. Besides this, the wonderful panels with their spiral ornaments, likewise covering the full height, draw the gaze upwards, and the apertures for the niches are much more elegant than their almost window-like counterparts on Prambanan. In general, the horizontalism at Prambanan, created by the heavy horizontal framework of the sub-basement, foot and middle frames, and cornices of the body and the clearly marked sections of the superstructure of the temple, is more emphatic than at Kalasan, even though the vertical tendencies also dominate at Prambanan. The counterweight of the vertical elements is more marked at Kalasan; the horizontal lines there are also pronounced but often less accentuated and less numerous than at Prambanan.

If we pause to compare the decorations of the façade fields of Prambanan and Kalasan, we are forced to draw the conclusion that the decorators of the Siva temple were less successful at their task than were those at Kalasan. This also emerges from a comparison of the sculpture on the lower regions of the Siva temple itself: the Prambanan motif, the lotus vases, relief panels, and figures are a disappointment next to the niche crowns in the shape of temple superstructures and the tendril jambs with 'recalcitrant spirals'. In this, Kalasan has no difficulty in defending its title: its decoration remains unrivalled.

The tendrils at Prambanan rise up from a small lion on an elephant in the first frieze, and from a human figure in the second, both contained within a shallow niche. Parallel with the tendrils and separated from them by a smooth jamb runs a narrow band with rosettes. In the panels on either side of the entrances, the niche has been compressed and the tendril jambs have been left out. The crowning of the niches is more reminiscent of the top of the entrance doors than those of the temple itself. They are borne by natural-looking kāla. Heavenly beings float alongside the pediment.

The main mouldings above the architrave contain a varied package of ornamental bands: a frame with halved octagonal rosettes, one with garlands and rosettes, a cornice with antefixes, a receding frame with floral motifs. ${ }^{34}$ Above this abuts the beginning of the girdle of niches, the one with the first frieze of bells which forms the pediment of the temple body, at the same time serving as the transition to the superstructure (roof storey 0 ). Above this rise

34 One of these is by Van der Hoop, Indonesische siermotieven (1949), pl. XXXIV, lower right depicted motif from Sewu. 


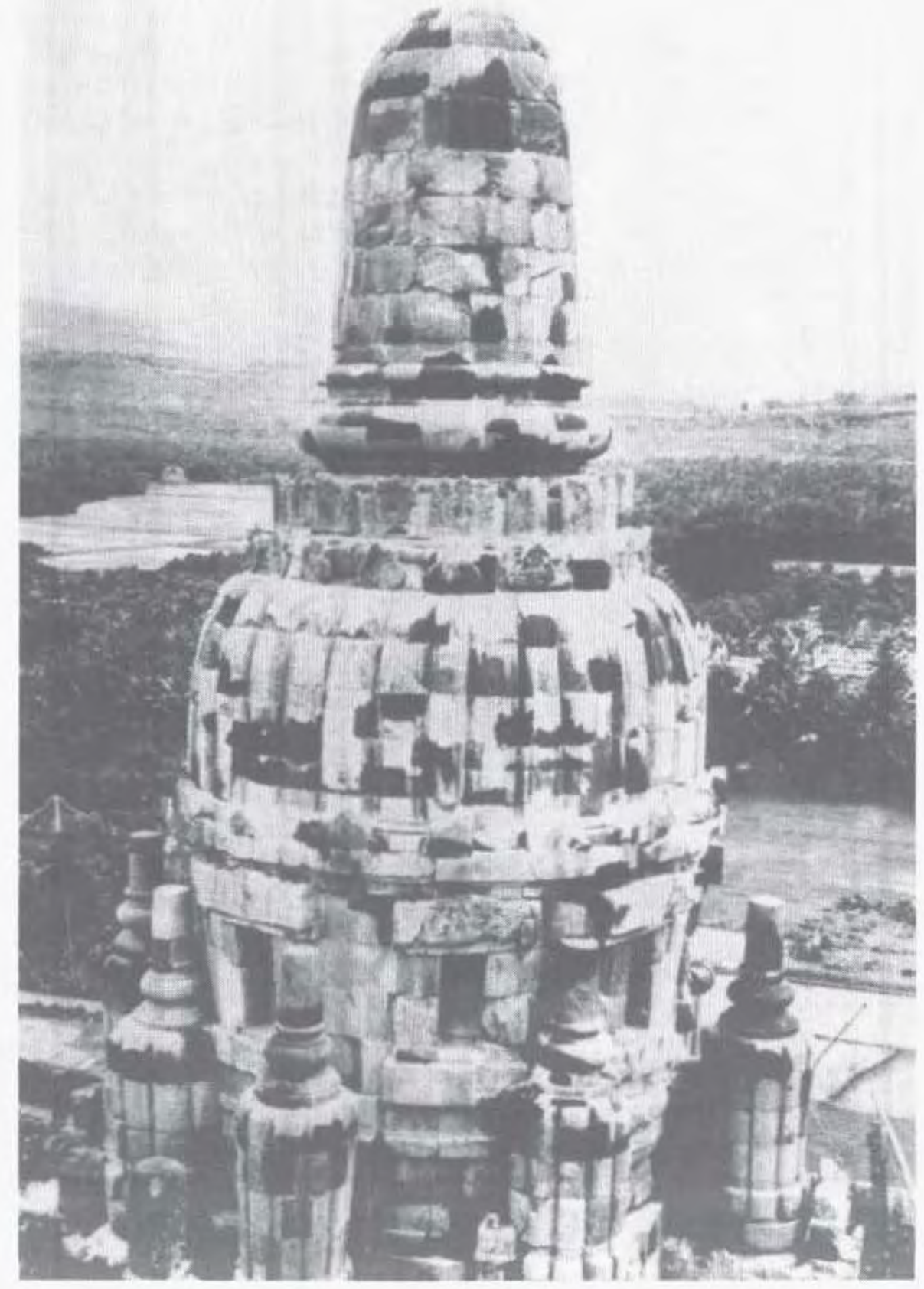

Photo 28. View on the top of the Śiva temple (reproduced from Bernet Kempers 1955) 
four more storeys (I-IV), each topped with a frieze of bells, and then the central bell. The bells stand at the true corners and along the sides of the projections. with the exception of the true corners of the third section above the frieze of niches. Here there was not enough room for a bell. As already discussed, the body of the next storey emerges from within each frieze of bells. The last frieze encircles the central bell (Photo p. 222).

In fact the frieze of niches consists of parallelopipeds above the projections and cubes above the true corners. Along the sides of these blocks niches have been placed above projections 2-3-2, above the true corners 1-1, 36 in total. No trace has been found of the statues which, going by the indentations, must once have stood in them. Between the niches are panels with a diamond-rosette decoration. Although the parallelopipeds and cubes are marked as separate entities by a receding section at the border of projection and square on the roof plan, the series of niches nonetheless creates an effect of a frieze of niches. And 'the effect' and 'the spectator' are important matters in this building. In principle. the commencement of the temple superstructure in this way is the same as at Kalasan and the continuation at the projections is also comparable. However, whereas at Kalasan, which is much less high, there is only one eube on top of the first parallelepiped with possibly yet a smaller block on top of this ${ }^{35}$, Prambanan displays a piling up of blocks, which decrease markedly in breadth but still retain a fairly large depth. We have already seen that this makes the plan of the higher storeys much more strongly cruciform. The silhouette of the temple elevations presents a slight curvature, especially because of the course of the projections, in which the plastic ornamental pieces create a supple transition between the horizontal sections. This curved line determines the sikhara character of the 'external' temple superstructure.

At Kalasan there are no following sections on top of the cube crowned by a stüpa above the true corners. Here the higher parts of the superstructure consist of two mighty octagons, which pile up the core of the superstructure and the base of the central pinnacle, possibly to form a large stũpa ${ }^{36}$ The blocks above the projections are placed against it. Prambanan lacks such a massive core. Here the central rectangle becomes ever smaller as it gains in height, and the projections ever larger (see above). Here, because the true corners present a sharply rising silhouette, steeper than the projections, at the sides of these projections in the higher storeys there is a proportionally large amount of space left over. This has necessitated placing two of the larger lype, and in both the uppermost

35. Cf, the drawing by Professor Van Romondt in Kalasan dan Sari, fig. 3.

Th See the reconstruction drawing (ibidem, at the back), made by the Architectural Section of the Archaeological Service. 
storeys three of the more slender type used there, above the bells of the frieze of niches. The bells above the true corners - as more direct descendants of the ämalakas - are then again a somewhat larger model than those in the niche frieze. In the upper storeys they are smaller, while in the penultimate, as was said, there was absolutely no room if the crown of eight had to find space around the base of the pinnacle. This uppermost circle stands turn and turn about either directly against or at a small distance from the base of the central bell. The number of bells is $28+4,36+4,32+4,4,4+4$ in the superstructure, 66 on the balustrade, $4 \times 3$ above the kāla heads of the entrances, thus 199 in total.

The roof section I above the frieze of niches $(0)$ still contains a number of niches, but only next to the true corners, in other words to the right and left of the bells on the cubes of the niche frieze. The remaining fields contain an ornament which serves to fill it in.

Each storey has a composite cornice: 0 (niche frieze) two mouldings with antefixes, separated by a decorated band, I and II ornamented supporting frames, a smooth cornice, antefixes with ornaments between them, antefixes with a smooth band between them. Above these are alternate projecting panels and receding casements. In the panels are gana-telamons, one in the centre, two at the corners. At least this is the case on the projections; there are no telamons, panels, nor casements above the true corners, because here the bottom part of the bells is decorated with antefixes. In I and II there are also ganas in the true corners.

Between the bells on the central elevation are eight small niches, which are now empty. They cover the lower half of the bell, separated from the incised upper part by a central band of antefixes. Two circular mouldings with antefixes and two semicircles form both the dividing line and the base for the whole of the pinnacle, which at 47 metres is the highest part of the monument.

When one beholds this mighty temple one wonders how it was possible, centuries ago, to raise the pieces of stone weighing hundreds of kilos to such great heights. In the vicinity of the foundations of the Śiva temple have been found blocks of marl, some with shallow, squarish grooves, some with deep round holes. ${ }^{37}$ It is possible that these once formed the foundation for scaffolding. Were the constructions perhaps used for the higher parts of the building in the nature of a sloping causeways, which one still comes across in the construction of gates and other such buildings in Bali? As a matter of fact,

37 O.V. 1938, p. 8 fig. 5. Could the 'batu-kenong'-like stone around Selogriyo (R.O.C. 1912 , p. 89, pl. 23) have served the same purpose? Batu kenong (stones with the shape of the musical instrument the kenong) known from other sites were socles for dwellings on piles. 
while passing the construction of the building for Gadjah Mada University in Yogyakarta recently, it struck me that a scaffold, which was being used there for the construction of the upper storeys, also resembles a sloping ramp.

Another technical matter is that of the foundations. The central temple square of Prambanan is situated four metres above the surrounding area. It does not stand on a natural elevation like Borobodur, but on an artificial mound, raise in a terraced fashion between the first and second enclosing walls. Each of the temples stands on a stone substructure, the one at the main temple having been given the most attention. It is raised in marl on a foundation of river stones mixed with sand, about one metre thick, $4.60 \mathrm{~m}$ below the surface of the square. Whereas the inner construction of the sub-basement of the other temples is also of marl, at the main temple, from $60 \mathrm{~cm}$ below surface level, it is of andesite. The walls of the temple pit pertaining to the large temples are also of andesite, while those of the ancillary temples are of sandstone. ${ }^{38}$ An interesting insight into the innards of such a candi was offered not so long ago (1953) at the southern main temple at Plaosan, to the northeast of Prambanan. Before work was started on the rebuilding, which is now underway, the foundations were investigated. It appeared that the body of the temple and the walls of the terrace which form a gallery around it (sub-basement) were separately provided with a marl substructure on a foundation of river stones. The 'cosmetic work', the andesite wall with moulding and ornamentation, is set against the broad substructure of the sub-basement. Inside this is interior work also of andesite, and inside this again there is marl. This vertically laid mass of stone was to support the marl substructure of the temple body, which continues to greater heights, separated by a filling of river stones.

The raised ground between the substructure of the temples at Prambanan is reinforced with a subterranean walling of river stones. This was most clearly visible during the excavation of the area between the first and second row of auxiliary temples at the northern staircase of the innermost enclosing wall. However, they have also been found in the central area (see Photo p. 60). ${ }^{39}$

All that remains to be said is a short note about the restoration of the subsidiary temples. At the first temple ruins on the site between the first and second enclosing wall, where a reconstruction was attempted, for instance in the southeastern corner of the central square, the result was disappointing. A subsequent

39 O.V. 1931-35, fig. 9; 1936, p. 8 and fig. 4. Photographs O.D. 11401 and 11786. Krom, Jaarb. Kon. Akad. Wer. 1939-40 suggests the possibility that these piles of river stones are the remains of an ancient Indonesian terrace sanctuary on this site. I do not think this likely. 
attempt met with more success. This temple, in the second row inside to the south of the east-west axis on the eastern side, has been completely rebuilt with a total height of about 14 metres. We have already said something about the relative correspondence with the gateways of the Śiva temple. The central band here is also an analogy to that of the main temple; the architrave is not so high that it needed to be split off for reasons other than this analogy. On the superstructure, instead of the incised bells of the ancillary and main temples, there are roof turrets. Here, as well, they are set above the projections in groups of three with the accent on the middle one, just as are the bells of the main temples. Above 0 rise storeys I, II, and III, with the pinnacle inside III.

The temple pit pertaining to this small edifice contains only rubble, but under the rubble, which formed the bottom, was found a stone casket buried in the ground, consisting of three pieces placed one on top of the other. The contents of this casket have not yet been investigated.

At the moment work is being carried out on the subsidiary temple in the north-east corner. The remarkable aspect of this, and in fact of all the subsidiary temples located on all the corners of the four squares, is that there are two staircases and two entrances to the temple chamber.

It appears that one of the subsidiary temples was never finished; the builders never got any further than the beginning of the roof.

The work on these smaller temples shows that the research on the rebuilding of Prambanan has by no means stopped. In fact, quite the opposite is true, and the Dinas Purbakala [Archaeological Service] is pursuing its activities with zeal. Anybody wondering what has happened to the great scaffolding of the Siva temple does not have far to look to see that what could still be used is now once more proving its worth. After having done service at Prambanan since 1937, the heavy teak poles now stand by the southern main temple of Plaosan which, just like the Śiva temple, will be completely resurrected in the near future. 


\section{Glossary}

Ādibuddha

Ādipurușa

àgama

akșamâlã

āmalaka

amrta

amṛtamanthana

anga

ańgahāra

añjalimudrã

apsaras

āsana

aștadikpâlas

Asura

avadāna

avatāra

Bhairava

bodhisattava

caitya

cakra

cầmara

Caṇựi

candi

culik

đākinī

dharma

dhyảnibuddha

dikpāla 'primal Buddha', a Buddha who is the primal source of reality and the ultimate goal and motive for enlightenment; the predominant Buddha in Mahãyāna.

'the first man', a primeval creature

'that which has come down', i.e., traditional religious teaching, contained in non-Vedic texts

rosary or string of beads

cushion-shaped, ornamental object

'not dead', 'immortal', 'imperishable'; the elixer of life, holy water churning of the Ocean of Milk in order to obtain amrta

major limb; a technical term in the Indian science of dancing (Nătyašâstra)

Indian term for a particular dance pose

handpose of reverential salutation

seductive, heavenly nymph, a celestial dancer of the gods

seat, throne, sitting posture

eight guardians of the sky

demon, opponent of the gods

Buddhist legendary tale

a divine incarnation

'the terrible one', name of one of the fierce aspects of Śiva

Buddha-to-be; a being who is to become fully enlightened or to possess bodhi (enlightenment)

shrine, memorial edifice, funeral monument

discus or sharp circular missile weapon

fly-whisk

one of the names of the Great Goddess Devi

Javanese term for a Hindu-Buddhist temple; pre-Islamic ruin

(victim of) kidnapping for sacrificial purpose

demoniac, quasi-divine being in Hindu and Budhist tantrism, and folklore

'foundation', 'support', 'principle', 'moral law; the Buddhist doctrine

epithet for a perfectly enlightened being, in Buddhist texts referred to as Tathāgatas or Jinas

guardian of the sky 


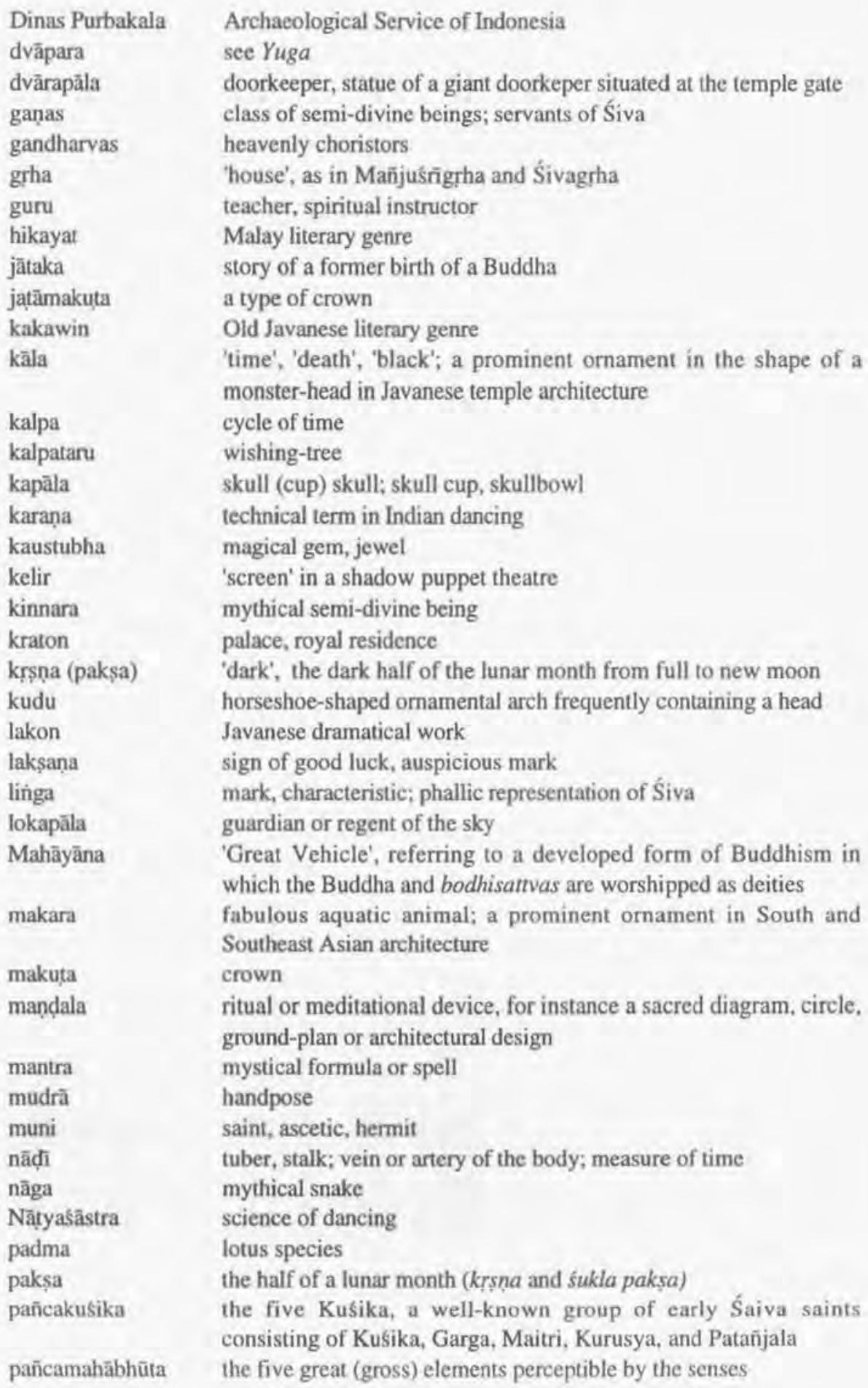




\begin{tabular}{|c|c|}
\hline pendheman & sacrifice of a buffalo \\
\hline pradakșinā & circumambulation in clock-wise direction \\
\hline prâsāda & temple building \\
\hline prthivi/prthvi & 'the broad or extended one', the earth; earth as element; ground \\
\hline purāna & genre of Sanskrit texts \\
\hline purușamedha & human sacrifice \\
\hline räkşasa & evil being or demon \\
\hline ratma & jewel \\
\hline rssi & $\begin{array}{l}\text { saint or sage; an ascetic or anchorite (a few orders of these are } \\
\text { enumerated (viz., Devarșis, Brahmarsis, Rãjarșis, Mahärsis, etc.) }\end{array}$ \\
\hline rudras & terrifying deities \\
\hline Śaiva & pertaining to Śiva; a worshiper of Śiva \\
\hline Śaiva Siddhânta & early literature of Śaiva sects; the name of a particular Śaiva sect \\
\hline Śaka & $\begin{array}{l}\text { era in Indian time-reckoning; a dating system commonly used in } \\
\text { Indonesian inscriptions }\end{array}$ \\
\hline sangha & congregation; in Buddhism denoting the community of monks \\
\hline Sankha & triton shell \\
\hline sarga & section, chapter, book, canto (esp. in an epic poem) \\
\hline sattva & $\begin{array}{l}\text { living being, creature; the centripetal force of cohesion (see also } \\
\text { tamas) }\end{array}$ \\
\hline siddha & $\begin{array}{l}\text { accomplished; succesful; endowed with supernatural faculties; } \\
\text { sacred }\end{array}$ \\
\hline $\begin{array}{l}\text { siddhayãtral } \\
\text { siddhiyãtra }\end{array}$ & magical power \\
\hline sikhara & $\begin{array}{l}\text { spire, turret, pinnacle, pointed end; high pointed tower in Indian } \\
\text { architecture }\end{array}$ \\
\hline sila & sitting posture \\
\hline silpašãstra & genre of Sanskrit texts on crafts, fine arts, and architecture \\
\hline silpin & artisan, craftsman, artist \\
\hline şrîvatsa & $\begin{array}{l}\text { auspicious mark or sign denoting a great man, or signifying divine } \\
\text { status }\end{array}$ \\
\hline stûpa & Buddhist monument, dagoba (often bell-shaped). \\
\hline stūpi(ka) & dome-like or pot-shaped finial \\
\hline sukla (pakșa) & 'bright'; the half of a lunar month from new moon to full moon \\
\hline sûryasevana & sun worship \\
\hline svastika & auspicious, whirl-shaped magical mark or motif \\
\hline tamas & $\begin{array}{l}\text { 'darkness', 'disintegration', 'dispersion', 'inertia'; centrifugal } \\
\text { force leading to disintegration (see also sattva) }\end{array}$ \\
\hline tambak/tamwak & pond, pool \\
\hline $\begin{array}{l}\text { Tãndava } \\
\text { tantra }\end{array}$ & $\begin{array}{l}\text { Śiva's cosmic dance of creation and destruction } \\
\text { chapter, text; esoteric teaching }\end{array}$ \\
\hline Tantrism & $\begin{array}{l}\text { esoteric Hindu or Buddhist doctrines; developed forms of } \\
\text { Hinduism and Mahãyãna Buddhism in which magic practices } \\
\text { feature prominently }\end{array}$ \\
\hline & 'warmth', 'heat'; the heat generated by ascetic practices, \\
\hline
\end{tabular}




\begin{tabular}{|c|c|}
\hline firtha & $\begin{array}{l}\text { ford, crossing, passage, holy spot; by extension 'holy bathing } \\
\text { place'. 'pool', 'holy water' }\end{array}$ \\
\hline Trimūrti & the Hindu triad of gods consisting of Brahmã, Vişnu, and Śiva \\
\hline Triraina & Three jewels', term denoting the Buddha, Dharma, and Sangha. \\
\hline trisũla & trident \\
\hline upānga & $\begin{array}{l}\text { minor limb or component part of the Angas, a term used in } \\
\text { connection with Indian dance }\end{array}$ \\
\hline Upanişads & $\begin{array}{l}\text { a collection of ancient Indian. Vedic texts containing esoteric } \\
\text { teachings }\end{array}$ \\
\hline upavīta & sacred cond; Brahmanical cord \\
\hline utpala & the blossom of the blue lotus \\
\hline vāhana & vehicle or mount of a deity \\
\hline vajra & $\begin{array}{l}\text { 'thunderbolt': 'diamond', 'sacred weapon; a symbolic term in } \\
\text { Tantrism denoting durability and the cutting power of wisdom }\end{array}$ \\
\hline Vajrayäna & $\begin{array}{l}\text { 'the vehicle of vajra', synonymous with Mantrayãna or Tantrayāna } \\
\text { Buddhism }\end{array}$ \\
\hline vara(da)mudrā & $\begin{array}{l}\text { handpose, outward turned open palm; 'gesture of the granting of } \\
\text { wishes' }\end{array}$ \\
\hline văstupuruşa & $\begin{array}{l}\text { archetype or ideal design of a house or building personified as a } \\
\text { divinity }\end{array}$ \\
\hline Veda & $\begin{array}{l}\text { 'knowledge', a term specifically applied to the 'supreme sacred } \\
\text { knowledge' contained in the four Indian collections (samhitās) of } \\
\text { prayers and hymns, consisting of the Rgveda, Sāmaveda, } \\
\text { Yajurveda, and Atharvaveda. Also included in the vedic corpus are } \\
\text { the Brähmanas (treatises on sacrifieial ritual), appended to the } \\
\text { above texts, and the Aranyakas and Upanişads (metaphysical and } \\
\text { philosophical speculations on ultimate reality) }\end{array}$ \\
\hline $\begin{array}{l}\text { Vedavyãsa } \\
\text { vidyādhara/ }\end{array}$ & arranger, editor or compiler of the Vedas \\
\hline $\begin{array}{l}\text { vidyādhari } \\
\text { wayang }\end{array}$ & $\begin{array}{l}\text { 'bearer of wisdom', benificent aerial spirit of great beauty } \\
\text { genre of Javanese theatre }\end{array}$ \\
\hline wayang kulit & Javanese shadow puppet theatre \\
\hline yaksas & class of semi-divine beings; tutelary spirits \\
\hline yoga & $\begin{array}{l}\text { the practice of self-concentration or abstract meditation: the effort } \\
\text { that is demanded in order to attain the union of the individual soul } \\
\text { with the Cosmic Soul or the Supreme Being }\end{array}$ \\
\hline yogi & practitioner of yoga \\
\hline yoni & 'vagina'; in Hindu sculpture, the base for a linga \\
\hline yoga & $\begin{array}{l}\text { measure of time; one of the four periods or ages of the world's } \\
\text { existence (viz., krta, tretā, dvâpara, kali) }\end{array}$ \\
\hline
\end{tabular}




\section{Bibliography}

Aichele, W.

1969

'Vergessene Metaphern als Kriterien der Datierung des altjavanischen Rāmāyana', Oriens Extremus 16:127-67.

Amerta

1952

Amerta: Warna Warta Kepurbakalaan I. [Djakarta]: Dinas Purbakala Indonesia. [Reprinted in 1985 as Amerta; Berkala Arkeologi I by the Pusat Penelitian Arkeologi Nasional, Jakarta.]

Annual Report

1911

Annual Report 1910-1911: Archaeological Survey of India. Calculta: Superintendent Government Printing.

Anom, I.G.N.

[1992] (ed.) Candi Sewu; Sejarah dan pemugarannya. Yogyakarta: Suaka Peninggalan Sejarah dan Purbakala Jawa Tengah.

[1993] (ed.) Candi Wahana; Pelestarian dan pemanfaatan. [Yogyakarta]: Departemen Pendidikan dan Kebudayaan.

Auboyer, 3.

1951 Art et styles de l'Inde. Paris: Larousse.

Bastin, J.

1953

'Colonel Colin Mackenzic and Javanese antiquities', Bijdragen tot de Taal-, Land-en Volkenkunde 109:273-5.

Baumgartner, A.

1894 Das Rāmāyana und die Rāma-literatur der Inder: Eine literaturgeschichsliche Skizze. Freiburg: Herder.

Behrend, Timothy

1989 'Kraton and cosmos in traditional Java', Archipel 37; 173-87.

Bernet Kempers, A.J.

1949 'De oudheidkundige dienst in en na de oorlog'. Tijdschrift voor Indische Taal-, Land-en Volkenkunde (TBG) 83:286-300.

1954 'Oudheidkundig werk in Indonesië na de oorlog', Indonesië 7:481-513.

1955a Bali Purbakala; Petunjuk tentang peninggalan2 purbakala di Bali. Djakarta: Penerbitan dan Balai Buku Indonesia. [Seri Tjandi 2.] [Reprinted in 1960. Djakarta: Ichtiar.] 

6-37.

1959

Ancient Indonesian art. Amsterdam: Van der Peet.

1978 Herstel in eigen waarde; Monumentenzorg in Indonesië. Zutphen: Walburg.

Bernet Kempers, A.J, and R. Soekmono

1954 Kalasan dan Sari. Jakarta: Balai Buku Indonesia. [Seri Tjandi 1.]

Bhandarkar, R.G.

1913 'Vaișnavism, Śaivism and minor religious systems', Grundriss der IndoArischen Philologie und Altertumskunde (Encyclopedia of Indo-Aryan Research) III. Band, 6. Heft, pp. 1-170. Strassburg: Trübner.

Bhattacharya, Kamaleswar

1955 'La secte des Pâaçupata dans l'ancien Cambodge', Journal Asiatique 243: 479-90.

1961 Les réligions brahmaniques dans l'ancien Cambodge d'après l'épigraphie et l'iconographie. Paris: École Française d'Extrême-Orient.

1973 L'Atman-Brahman dans le Bouddhisme ancien. Paris: École Française d'Extrême-Orient.

Bhattacharya, S.K.

1978 Krsşa-cult. New Delhi: Associated Publishing House.

Bhattacharyya, Benoytosh

1958 The Indian Buddhist iconography mainly based on the Sädhanamālā and other cognate Tantric texts of rituals. Second revised edition. Calcutta: Mukhopadhyay. [First published 1924, London: Oxford University Press.]

Blom, J.R. van

1935 Tjandi Sadjiwan, Leiden/Amsterdam: Stenfert Kroese. [PhD thesis Rijksuniversiteit Leiden.]

Boechari

1965 'Epigraphy and Indonesian historiography', in: An introduction to Indonesian historiography, pp, 47-74. Ithaca: Cornell University Press.

1978 'Bahan kajian arkeologi untuk pengajaran sejarah', Majalah Arkeologi 1:3-26,

1982 'Aneka catatan epigrafi dan sejarah kuna Indonesia', Majalah Arkeologi 5:15-38.

Bonheur, Albert le

1971 La sculpture indonésienne au Musée Guimet; Catalogue et étude iconoBosboom, H.D.H. graphique. Paris: Presses Universitaire de France.

1903 'Tempelwachters te Prambanan?', Bijdragen tot de Taal-, Land- en Volkenkunde 55:281-2. 
Bosch, F.D.K.

1920a 'Een hypothese omtrent den oorsprong der Hindoe-Javaansche kunst', in: Handelingen van het Eerste Congres van Taal-, Land-en Volken. kunde van Java, Solo 25-26 december 1919, pp, 93-119. Weltevreden: Albrecht. [Reprinted in English, 1924.]

1920b 'De inscriptie op het Aksobya-beeld van Gondang-Lor'. Tijdschrift voor Indische Taal-, Land-en Volkenkunde (TBG) 59:498-528.

1921 De inscriptie op het Mañjuśri-beeld van 1265 Saka', in: Verslag van hel Eerste Congres van het Oostersch Genootschap, pp. 46-7. Leiden: Brill.

1923 God Brahmā omringd door Māharși's (Epigrafische en iconografische aanteekeningen), Oudheidkundig Verslag 1922:66-70.

1924 'A hypothesis as to the origin of Indo-Javanese art', Rupam 17:6-41,

1928 'De inscriptie van Kĕloerak', Tijdschrift voor Indische Taal-, Land-en Volkenkunde (TBG) 68:1-65.

1929a [Review of:] 'W.F. Stutterheim; A Javanese period in Sumatran history, Surakarta: 1929', Tijdschrift voor Indische Taal-, Land-en Volkenkunde (TBG) 69:135-56

$1929 \mathrm{~b}$ Buddhistische gegevens uit Balische handschriften', Mededeelingen van de Koninklijke Nederlandse Akademie van Wetenschappen 68:43-77.

1939 'De reliëfreeks aan de yoorzijde der eerste balustrade van Baraboedoer'. in: Verslag van het Negende Cangres van het Oostersch Genootschap. pp. 31-2. Leiden: Brill.

1946 Het vraagstuk van de Hindoe-kolonisatie van den archipel. Leiden: Stenfort Kroese. [Inaugural address.]

1952 ' "Local genius" en Oud-Javaanse kunst', Mededeelingen der Koninklijke Akademie van Wetenschappen, Afdeling Letterkunde 15-1:126.

1954 Uit de grensgebieden tussen Indische invloedsfeer en oud-inheems volksgeloof op Java', Bijdragen tot de Taal-, Land-en Volkenkunde 110: 1-19.

1958 [Review of:] 'J.G. de Casparis, Prasasti Indonesia II, Bandung, 1956', Bijdragen tot de Taal-, Land-en Volkenkunde 114:306-19.

1959 'On some groups of Yakşa figures in Indonesian and Khmer art', Artibus Asiae 22:227-39

1961a [Review of:] 'Alastair Lamb, Chandi Bukit Batu Pahat; Idem: Chandi Bukit Batu Pahat; Three additional notes', Bijdragen tot de Taal, Landen Volkenkunde 117:485-91.

1961b 'The problem of the Hindu colonisation of Indonesia' [Translation of inaugural address of 1946], in: Selected studies in Indonesian archeology, pp. 3-23. The Hague: Nijhoff. [KITLV, Translation Series 5.]

Braginsky, V.I.

1983 Istorya Malayskoy literartury VII-XIX Vekov (A history of Malay literature of the 7th-9th Century). Moskva: Nauka.

1993 The system of classical Malay literature. Leiden: KITLV Press. [Working Papers 11.] 
Brandes, J.

1904

'De waarde van tjandi Prambanan tegenover de andere oudheden van Java, en een hartig woord over de deblayeering', Tijdschrift voor Indische Taal-, Land-en Volkenkunde (TBG) 47:4I4-32.

Brockington, J.L.

1984

Righteous Rāma, the evolution of an epic. Delhi: Oxford University Press.

Bronson, Bennet

1977

'Angkor, Anuradhapura, Prambanan, Tikal: Maya subsistence in Asian perspective', in: P.D. Harrison and B.L. Turner (eds), Pre-Hispanic Maya agriculture, pp. 255-300. Albuquerque: University of New Mexico.

Brumund, J.F.G.

1853-54 Indiana; Verzameling van stukken van onderscheiden aard, over landen, volken, oudheden en geschiedenis van den Indischen archipel. Amsterdam: Van Kampen. 2 Vols.

1868 Bijdrage tot de kennis van het hindoeïsme op Java', Yerhandelingen van het Bataviaasch Genootschap van Kunsten en Wetenschappen 33:1-310.

Casparis, J.G, de

1950 Prasasti Indonesia I; Inscripties uit de Çailendra-tijd. Bandung: Nix.

1956 Prasasti Indonesia II; Selected inscriptions from the 7th to the 9th century $A D$. Bandung: Masa Baru.

1958 Short inscriptions from Tjandi Plaosan Lor. Djakarta: Dinas Purbakala. [Bulletin of the Archeological Service of Indonesia 4.]

1964 'New evidence on cultural relations between Java and Ceylon in ancient times', Artibus Asiae 24:241-8.

Chandra, Lokesh

1967 'Unto the Śiva temple of Indonesia', Bulletin of the Institute of Traditional Cultures in Madras 2:246-52.

1986 'Cultural contacts of Indonesia and Sri Lanka in the eighth century and their bearing on the Barabudur', Journal of the Asiatic Society 28:38-56.

1989 'Preface', in: W.F. Stutterheim, Rāma-legends and Rāma-reliefs in Indonesia, pp. xi-xx. Delhi: Abhinav.

Christie, Jan Wisseman

1992 'Water from the ancestors; Irrigation in early Java and Bali', in: J. Rigg (ed.), The gift of water; Water management, cosmology and the state in South East Asia, pp. 7-26. London: School of Oriental and African Studies, University of London.

Coedès, G.

1934 'On the origin of the Sailendras of Indonesia', Journal of the Greater Indian Society 1-2:61-71.

1959 'L'inscription de la stèle de Ligor; État présent de son interpretation',

Oriens Extremus 6:42-8. 
1968 The Indianized states of Southeast Asia. Honolulu: The University Press of Hawaii. [Edited by Walter F. Vella, translated by Susan Brown Cowing.]

Cohn, W.

1921 Indische Plastik. Berlin: Cassirer.

Colebrooke, H.T.

1837 Miscellaneous essays. London: Allen. 2 Vols.

Coleman, $\mathrm{Ch}$.

1832 The mythology of the Hindus, with notices of the various mountain and island tribes inhabiting the two peninsulas of India and the neighbouring islands; And an appendix comprising the minor avatars, and the mythological and religious terms, etc. of the Hindus; With plates illustrative of the principal Hindu deities, etc. London: Parbury.

Colless, Brian E.

1970 'Walaing and the Sailendras of Java', Journal of the Oriental Society of Australia 7:15-22.

Coomaraswamy, Ananda K.

1927 History of Indian and Indonesian art. London: Goldston.

1986 Hinduism and Buddhism. New Delhi: Munshiram Manoharlal. [Second Indian edition; First edition 1943.]

Cowell, E.B.

1901

The Jâtaka or studies of the Buddha's former births. Vol. 4. Cambridge: University Press.

Crawfurd, J.

1820a 'The ruins of Prambanan in Java'. Asiatick Researches 13:337-68.

$1820 \mathrm{~b} H i s t o r y$ of the Indian archipelago, containing an account of the manners, arts, languages, religions, institutions, and commerce of its inhabitants. Edinburgh: Constable. 2 vols.

1856 A descriptive dictionary of the Indian islands and adjacent countries. London: Bradbury.

Cultureel Nieuws Indonesië

1954 'Oudheidkunde-nummer', Culturcel Nieuws Indonesië 36-37:1095-168.

Damais, L.-Ch.

1952

'Études d'épigraphie indonésienne III; Liste des principales inscriptions datées de l'Indonésie', Bulletin de l'École Française d'Extrême-Orient 46:1-105.

1968 'Bibliographie indonésienne', Bulletin de l'École Française d'ExtrêmeOrient 54:295-522.

Döhring, $\mathrm{K}$.

1923

Siam. Darmstadt: Folkwang. 3 Vols. [Der Indische Kulturkreis in Einzelndarstellungen.] 
Drewes, G.W.J.

1925 Drie Javaansche goeroe's, hun leven, onderricht en Messiasprediking.

Leiden: Vros. [PhD thesis Rijksuniversiteit Leiden.]

Dumarçay, Jacques

1954 'Les charpentes figurées de Prambanan', Archipel 7:139-150.

1981 Candi Sewu et l'architecture bouddhique du centre de Java. Paris: École Française d'Extrême-Orient. [Mémoires Archéologiques 14.]

1986a Candi Sewu dan arsiktektur bangunan agama Buda di Jawa Tengah. Jakarta: Puslit Arkenas.

1986b 'L'espace architectural indo-javanais', Archipel 31:73-85.

1986c The temples of Java. Singapore: Oxford University Press. [Translated and edited by Michael Smithies.]

[991 Borobudur. Kuala Lumpur: Oxford University Press. [Edited and translated by Michael Smithies; First published 1986.]

1993 Histoire de l'architecture de Java. Paris: École Française d'ExtrêmeOrient. [Mémoires Archéologiques 19.]

1994 'The beamwork illustrated at Prambanan', Indonesia 57:5-14.

Dutt, Nalinaksha

1978 Mahāyāna Buddhism. Delhi: Motilal Banarsidass.

Dwiyanto, Djokjo

1986 'Pengamatan terhadap data kesejarahan dari prasasti Wanua Tengah III tahun 908 M.', in: Pertemuan Ilmiah Arkeologi 4-IIa, pp. 92-111. Jakarta: Pusat Penelitian Arkeologi Nasional.

Echols, J.M. and Hassan Shadily

1990 Kamus Indonesia-Inggris; An Indonesian-English dictionary. Third edition. Jakarta: Gramedia. [First edition 1961.]

Eerde, J.C. van

'Hindu-Javaansche en Balische eeredienst', Bijdragen tot de Taal-, Landen Volkenkunde 65:1-39.

Eliade, Mircea

1976 The world, the city, the house', in: M. Eliade (ed.), Occultism, witchraft and cultural fashions; Essays in comparative religions, pp. 18-31. Chicago: University of Chicago Press.

Encyclopedie

1982

De grote Winkler Prins encyclopedie in 25 delen. Achtste, geheel nieuwe druk. Amsterdam/Brussel: Elsevier. [Eerste editie 1870-1882.]

Ensink, J, 1978

'Śiva-Buddhism in Java and Bali', in: H. Bechert (ed.), Buddhism in Ceylon and studies on religious syncretism in Buddhist countries; Report on a symposium in Göttingen, pp. 178-99. Göttingen: Vandenhoeck and Ruprecht.

Erp, Th. van 1903

Verslag betreffende de herstelling der nevencella's van den hoofdtempel van Prambanan. [Unpublished report.] 
1909 'Hindu monumental art in Central Java', in: A. Wright (ed.), Twentieth century impressions of Netherlands India, pp. 136-72. London: Lloyd.

1911 'Vondst van een merkwaardige Garuḍa van de Prambanan-vlakte', in: Rapporten van de commissie in Nederlandsch-Indië voor oudheidkundig onderzoek op Java en Madoera, pp. 74-6. Batavia: Albrecht.

1917 'Eenige mededeelingen betreffende de beelden en fragmenten van Boroboedoer in 1896 geschonken aan Z.M. den Koning van Siam', Bijdragen tot de Taal-, Land-en Volkenkunde 73:285-310.

1921 'Het ornament in de Hindoe bouwkunst op Midden Java', in: Verslag van het Eerste Congres van het Oostersch Genootschap, pp. 10-2. Leiden: Brill.

1923 'Hindu-Javaansche beelden thans te Bangkok', Bijdragen tot de Taal-, Land-en Volkenkunde 79:491-518.

1926 'Overzicht van bedenkingen tegen de details der op het terrein uitgevocrde reconstructies van den Çiwa-tempel van Prambanan', in:Verslag van de cammissie van advies inzake de restauratie der Hindoe-Javaansche mommenten, nopens de reconstructie van den Ciwatempel te Prambanan, pp. 25-34. Weltevreden: Kolff.

1927 'Nog eens de Hindu-Javaansche beelden te Bangkok', Bijdragen tot de Taal-, Land-en Volkenkunde 83:503-13.

1931 Bouwkundige beschrijving; Beschrijving van Barabudur, samengesteld door N.J. Krom en T. van Erp, Tweede Deel. 's-Gravenhage: Nijhoff. [KITLV.]

1943a 'Een prachtige Wanaspati in het Rijksmuseum voor Volkenkunde te Leiden', Maandblad voor Beeldende Kunsten 20:69-72.

1943b 'Iets over de verlichting der cella van Hindoe-Javaansche heiligdommen', Maandblad voor Beeldende Kunsten 20:145-54.

$1943 \mathrm{c}$ 'De Indische geluksgodin met de olifant', Maandblad voor Beeldende Kunsten 20:190-2, 214-6.

Fontein, Jan

1989

The law of cause and effect in ancient Java. Amsterdam: North-Holland Publishing Company. [Verhandelingen Koninklijke Nederlandse Akademie van Wetenschappen, Afdeling Letterkunde, Nieuwe Reeks 140.]

1990 The sculpture of Indonesia. Washington: National Gallery of Art.

forthcoming Preliminary notes on the narrative reliefs of Candi Brahmā and Candi Vișnu at Loro Jonggrang, Prambanan'. [To be published in a Liber Amicorum for Jean Boisselier.]

Friederich, R.

1854-57 Over inscriptiên van Java en Sumatra voor het eerst ontcijferd', Verhandelingen van het Bataviaasch Genootschap van Kunsten en Wetenschappen 26:1-99.

1876 'Rapport over reizen gedaan op Java', Tijdschrift voor Indische Taal-, Land-en Volkenkunde (TBG) 23:42-111. 
Garbe, $R$.

1917 Die Sãmkya-Philosophie; Eine Darstellung des Indischen Rationalismus. Leipzig: Haessel.

Gericke, J.F.C. and T. Roorda

1901 Javaansch-Nederlandsch handwoordenboek. Amsterdam: Müller, Leiden: Brill. 2 vols.

Ghosh, Mallar

1980 Development of Buddhist iconography in Eastern India: A study of Tārā, Prajñās of five Tathāgatas and Bhrikutị. New Delhi: Munshiram Manoharlal.

Gomez, Luis O.

1987 'Buddhism in India', in: Mircea Eliade (ed.), The encyclopedia of religion, Vol. 2, pp. 351-85. New York: Macmillan.

Gonda, J.

1970 'Karman and retributive justice in ancient Java', in: H.B. Sarkar (ed.), R.C. Majumdar felicitation volume, pp. 225-37. Calcutta: Mukhopadhyay.

Goris, R.

1926

Bijdrage tot de kennis der Oud-Javaansche en Balineesche Theologie.

[PhD thesis Rijksuniversiteit Leiden.]

Groeneveldt, W.P.

1887 Catalogus der archaeologische verzameling van het Bataviaasch Genootschap van Kunsten en Wetenschappen. Batavia: Albrecht.

Groneman, J.

1887 'De Vereeniging voor Oudheid-, Land-, Taal- en Volkenkunde te Jogjakarta, en de Tjandi Parambanan', Indische Gids 9, II:1426-46.

1893 Tjandi Parambanan op Java, na de ontgraving; Met lichtdrukken van Cephas. Leiden: Koninklijk Instituut voor Taal-, Land- en Volkenkunde van Nederlandsch-Indië.

Grünwedel, A.

1900 Mythologie des Buddhismus in Tibet und der Mongolei; Führer durch die lamaistische Sammlung des Fürsten E. Uchtomsky. Leipzig: Brockhaus.

Gupta, S., D.J. Hoens and T. Goudriaan

1979 Hindu Tantrism. Leiden/Köln: Brill. [Handbuch der Orientalistik, II. Abt., 4 Band, 2 Abschnitt.]

Hardjowardjojo, R.P. Pitono

1967 'Prambanan's temples honour Hindu deities', Hemisphere 11(12):10-4.

Heine-Geldern, Robert von

1930 'Weltbild und Bauform in Südostasien', Wiener Beiträge zur Kunst- und Kulturgeschichte Asiens 4:28-79.

1967 "The cosmological foundations of Southeast Asian architecture', Journal of the Historical Society of Singapore 2:50-3. 
Helfritz, $\mathrm{H}$.

1979

Indonesië; Kunst en kultuur van Java, Sumatra, Bali en Sulawesi. De Bilt: Cantecleer. [Originally published in German, Köln: Dumont, 1977.]

Hillebrandt, A.

1921

Kälidāsa: Ein Versuch zu seiner literarischen Würdigung. Breslau: Marcus.

Hinlopen Labberton, D. van

1921 'Oud-Javaansche gegevens omtrent de vulkanologie van Java', Djäwă $1: 185-201$.

Hoepermans, N.W.

1914 'Hindoe-oudheden van Java', in: Rapporten van den Oudheidkundigen Dienst in Nederlandsch-Indië (ROD) 1913, pp. 73-355. Batavia: Albrecht.

Hoëvell, W.R. van,

1849 Reis over Java, Madura, en Bali, in het midden van 1847. Amsterdam: Van Kampen.

Holt, Claire

1967

Art in Indonesia; Continuities and change. Ithaca: Comell University Press.

Hoop, A.N.J. Thomassen à Thuessink van der

Indonesische siermotieven (Ragam-ragam perhiasan Indonesia: Indonesian ornamental design), Bandoeng: Nix. [Koninklijk Bataviaasch Genootschap voor Kunsten en Wetenschappen.]

Huntington, S.L.

1985 The art of ancient India. New York: Weatherhill.

Jahn, W.

1908 Das Saurapuränam; Ein Kompendium spätindischer Kulturgeschichte und des Śivaismus. Strassburg: Triibner.

Jochim, E.F.

1913

'Prambanan en omliggende tempels', Tijdschrift voor Indische Taal-. Land-en Volkenkunde (TBG) 55:470-514.

Jordaan, Roy E.

'A holy water sanctuary at Prambanan', Amerta; Berkala Arkeologi 11:17-41.

1991a 'Text, temple, tirtha', in: Lokesh Chandra (ed.). The art and culture of South-East Asia, pp. 165-81. Delhi: Aditya Prakashan.

1991b 'Ancient Javanese temple ruins identified', Review of Indonesian and Malaysian Affairs 25:64-74,

1991c 'Mengenal deskripsi reruntuhan candi di dalam karya sastra Jawa kuno', Majalah Arkeologi 7-1:3-21.

1992 'Sūrya and Nairtrta on the Śiva temple of Prambanan', Bijdragen tot de Taal-, Land-en Volkenkunde 148:59-67. 

of the Loro Jonggrang temple complex. Leiden: Vakgroep Talen en Culturen van Zuidoost-Azië en Oceanië. [Semaian 7.] 'Prambanan 1995; A hypothesis confirmed' [Report on a journey to Java], IIAS Newsletter 6:37.

Jordaan, Roy E. and Edi Sedyawati

1990 'Some iconographic notes on the Siva temple of Prambanan', Archipel 40:15-23.

Juynboll, Th.W.

$1930 \quad H a n d l e i d i n g$ tot de kennis van de Mohammedaansche wet volgens de leer der Sjafi'itische school. Leiden: Brill.

Kaelan

1960 Tjandi Lara Djonggrang; Petundjuk singkat. Jogjakarta: Tjabang Bagian Bahasa Kebudajaan, Dep. P.P. \& K.

Kat Angelino, P. de

1922

Mudra's op Bali; Handhoudingen der priesters. 's-Gravenhage/Hagen: Folkwang.

Kats, J.

1910 Sang hyang Kamahāyānikan; Oud-Javaansche tekst met inleiding, vertaling en aanteekeningen. 's-Gravenhage: Nijhoff.

1925 Het Rämäyana op Javaansche tempel reliefs; The Ramayana as sculptured in reliefs in Javanese temples. Batavia: Kolff.

Kern, $\mathrm{H}$.

1888 'Over de vermenging van Çivaïsme en Buddhisme op Java, naar aanleiding van het Oudjavaansch gedicht Sutasoma', Verslagen en Mededeelingen der Koninklijke Akademie van Wetenschappen, Afdeling Letterkunde, Derde Reeks, 5:150-77.

1916 'Over den vermoedelijken oorsprong der Nãga-vereering', Bijdragen tot de Taal-, Land-en Volkenkunde 72:395-8.

1917 'Het Sanskrit-opschrift te Tugu (distr. Bekasih, Batavia); \pm 450 A.D.', in: H. Kern, Verspreide geschriften 7, pp. 129-38. 's-Gravenhage: Nijhoff.

Khanna, Amar Nath

1992

Archaeology of India; Retrospect and prospect. Second revised edition. New Delhi: Clarion. [First edition 1981.]

Khanna, Vinod and Malini Saran

'The Rāmāyaṇa Kakawin; A product of Sanskrit scholarship and independent literary genius', Bijdragen tot de Taal-, Land-en Volkenkunde 149:226-49.

Klokke, Marijke J.

The Tantri reliefs on ancient Javanese candi. Leiden: KITLV Press. [Verhandelingen 153.] 
Knebel, J.

1911

'Inventarisatie der Hindoe-oudheden in de vlakten van Prambanan en Saregedoeg (Residentie Jogjakarta en Soerakarta) met beschrijving van de steenen Hindoe-beelden, behalve de reeds beschrevene in de rapporten der Oudheidkundige Commissie in 1902 (Archaeologische verzameling ter hoofdplaats Jogjakarta en op het erf van den Heer E. Kraag, aldaar, 305 en 29 nummers)', in: Rapporten van de commissie in NederlandschIndië voor oudheidkundig onderzoek op Java en Madoera 1909, pp. 20138. Batavia: Albrecht.

\section{Kompas}

$1990 \mathrm{a}$

'Penemuan $13 \mathrm{~kg}$ perhiasan emas kuno di Klaten', Kompas; Harian untuk Umum 26-122:1, I1.

1990b 'Emas kuno itu memendam sejarah', Kompas; Harian untuk Umum 26. 161:1.

1993 'Penemuan prasasti di Borobudur, mata rantai sinkretisme keagamaan'. Kompas; Harian untuk Umum 29-20:16.

Kramrisch, Stella

1946

The Hindu temple. Calcutta: University of Calcutta. 2 Vols.

1976 The Hindu temple. Delhi: Motilal Banarsidass. 2 Vols. [First published by the University of Calcutta, 1946.]

Krom, N.J.

1920

Inleiding tot de Hindoe-Javaansche kunst. 's-Gravenhage: Nijhoff. 3 Vols.

1923a Inleiding tot de Hindoe-Javaansche kunst. 's-Gravenhage: Nijhoff. 3 Vols. [Second revised edition.]

1923b Het oude Java en zijn kunst. Haarlem: Bohn.

1924 'Over het Çivaïsme van Midden-Java', Mededeelingen der Koninklijke Akademie van Wetenschappen, Afdeling Letterkunde 58 (B):199-226.

1927 Barabudur; Archaeological description. The Hague: Nijhoff. 2 Vols.

1931 a Beschrijving van Barabudur. Samengesteld door N.J. Krom en T. van Erp. 's-Gravenhage: Nijhoff, 3 Vols.

1931b Hindoe-Javaansche geschiedenis. Tweede, herziene uitgave. 's-Gravenhage: Nijhoff. [First edition 1926.]

1939 Indisch en Indonesisch', Jaarboek Koninklijke Akademie van Wetenschappen, Afdeling Letterkunde, pp. 185-201. Amsterdam: Koninklijke Akademie van Wetenschappen.

Kuntara Wiryamartana, I.

1992

The "sea" in Old Javanese literature', in: V.J.H. Houben, H.M.J. Maier and W. van der Molen (eds), Looking in odd mirrors; The Java sea, pp. 97-112, Leiden: Vakgroep Talen en Culturen van Zuidoost-Azië en Oceanië. [Semaian 5.]

Lamb, A.

1960a Chandi Bukit Batu Pahat: A report on the excavation of an ancient temple in Kedah. Singapore: Eastern Universities Press. [Monograph on Southeast Asian Subjects 1.] 
1960b 'Report on the excavation and reconstruction of Chandi Bukit Batu Pahat, Central Kedah', Federation Museums Journal New Series 5:1-108.

1961 Chandi Bukit Batu Pahat; Three additional notes. Singapore: Eastern Universities Press. [Papers on Southeast Asian Subjects 5.]

Laporan

Laporan tahunan Dinas Purbakala Indonesia. 1950. Djakarta: Dinas Purbakala Indonesia.

1993 Laporan pembenahan halaman pusat Candi Prambanan tanggal 15 Juni s/d I5 September 1993. [Bogem: Panitia Pemugaran Candi Wahana Lorojonggrang Prambanan Daerah Istimewa Yogyakarta, Dinas Purbakala.]

Leemans, $\mathrm{C}$.

1855

'Javaansche tempels bij Prambanan', Bijdragen tot de Taal-, Land-en Volkenkunde 3:1-26.

1873 Bôrô-Boedoer op het eiland Java, afgebeeld door en onder toezigt van F.C. Wilsen, met toelichtenden en verklarenden tekst, naar de geschreven en gedrukte verhandelingen van F.C. Wilsen, J.F.G. Brumund en andere bescheiden, bewerkt en uitgegeven op last van Zijne Excellentie den Minister van Koloniën. Leiden: Brill. 4 Vols.

Lévi, Sylvain

1903

'La légende de Râma dans un avadâna Chinois', in: Album Kern, pp. 279-81. Leiden: Brill.

Liebert, Gösta

1976

Iconographic dictionary of the Indian religions: Hinduism, Buddhism, Jainism. Leiden: Brill.

Liere, W.J. van

1980 'Traditional water management in the Lower Mekong basin', World Archaeology 11-3:265-80.

Lillie, A.

1881 Buddha and early Buddhism. London: Tribner.

Lohuizen-de Leeuw, J.E. van

1955

'The Dikpālakas in ancient Java', Bijdragen tot de Taal-, Land-en Volkenkunde 111:356-84.

1956 'South-East Asian architecture and the stūpa of Nandagarh', Artibus Asiae 19:279-91.

1957 'The ancient monastery at Pāhärpur', Antiquity and Survival 2-1:29-43.

1980 The stūpa in Indonesia', in: A.L. Dallapiccola and Stephanie Zingel-Ave Lallemant (eds), The stüpa; Its religious, historical, and architectural significance, pp. 277-300. Wiesbaden: Steiner.

Lorenzen, David N.

1972 The Käpãlikas and Kälāmukhas; Two lost Śivaite sects. Berkeley: University of California Press. 

demon devotees; Essays on the guardians of popular Hinduism, pp. 231-8. Albany: State University of New York Press.

Lulius yan Goor, $\mathrm{M}$.

1919 Korte gids voor de tempelbouwvallen in de Prambanan-vlakte, het Diëngplateau en Gedong Sanga. Weltevreden: Landsdrukkerij.

1929 'Prambanan', in: Fourth Pacific Science Congress, Java 1929; Excursion guides. Buitenzorg: Archipel. [Translated from the Dutch by H.S. Banner.]

Mabbett, 1.W.

1982

'A sketch of Mount Meru'. Paper prepared for the Asian Studies Association of Australia, Fourth national conference, Monash University May 10-14th.

Mackenzie, C.

1814 Narrative of a journey to examine the remains of an ancient city and temples at Brambana in Jaya', Verhandelingen van het Bataviaasch Genootschap van Kunsten en Wetenschappen 7:1-54.

Madras Epigraphical Report

1914 Madras epigraphical report for the year 1914. Madras: Government Press.

Mânava Dhama-Śâstra

1887 Mânava Dharma-Sáastra; The code of Manu original Sanskrit text critically edited according to the standard Sanskrit commentaries, with critical notes by J. Jolly. London: Trübner.

Martowikrido, Wahyono

1994 'The gold of Wonoboyo', in: W.H. Kal (ed.), Old Javanese gold (4th15th century): An archaeometrical approach, pp. 30-46. Amsterdam: KIT-Tropenmuseum.

Mengenal Candi Sambisari.

n.d.

Mengenal Candi Sambisari. [Yogyakarta:] Suaka Peninggalan Sejarah dan Purbakala, Daerah Istimewa Yogyakarta.

Miksic, J.

1990

1994

Borobudur; Golden tales of the Buddhas. Berkeley/Singapore: Periplus. [Review of:] 'Roy E. Jordaan, Imagine Buddha in Prambanan, Leiden 1993', Journal of Southeast Asian Studies, 25-2:442-4.

Mitchell, G.

1977

The Hindu temple; An introduction to its meaning and forms. London: Elek.

Moens, J.L.

1924

'Het Buddhisme op Java en Sumatra in zijn laatste bloeiperiode', Tijdschrift voor Indische Taal-, Land-en Volkenkunde (TBG) 64:521-80.

1953

'Lara Djonggrang en Prambanan; Van een sprookje dat werkelijkheid was', De Ronde Tafel 2-48:4, 12-3. 
Moertjipto et al.

The Ramayana reliefs of Prambanan. Yogyakarta: Kanisius.

Monier-Williams, M.

1986 A Sanskrit-English dictionary etymologically and philologically arranged with special reference to cognate Indo-European languages. Delhi: Motilal Banarsidass. [First published by Oxford University Press, 1899.]

Mus, $\mathrm{P}$.

1935 Barabudur; Esquisse d'une histoire du Bouddhisme fondée sur la critique archéologique des textes. Hanoi: Imprimerie d'Extrême-Orient. 2 Vols.

Naidu, Bijayeti Venkata Narayanaswami et al.

1936

Tändava Laksanam or the fundamentals of ancient Hindu dancin; Being a translation into English of the fourth chapter of the Nätya-Śästra of Bharata, with a glossary of the technical dance terms compiled from the eighth, ninth, tenth and eleventh chapters of the same work, illustrated with original photographs of the sculptured dance poses in the great temple of Śiva Natarāja at Chidambaram, and containing special appendices of aesthetic and archaeological interest. Madras: G.S. Press.

O'Connor, S.J.

1966 'Ritual deposit boxes in Southeast Asian sanctuaries', Artibus Asiae 28:53-61.

Oudheidkundig verslag

1912-49 Oudheidkundig versiag van de Oudheidkundige Dienst in NederlandschIndië. Batavia: Albrecht, Bandung: Nix.

Paranavitana, S.

The stūpa of Ceylon; Memoirs of the Archaeological Survey of Ceylon 5. Colombo: Government of Ceylon Press.

Parmentier, $\mathrm{H}$.

L'art architectural hindou dans l'Inde et en Extrême-Orient, Paris: Van Oest. [Les éditions d'art et d'histoire.]

Paul, Debjani

1978

'Deity or deified king? Reflections on a unique Vaisnavite sculpture from Java, Artibus Asiae 40:311-33.

Pigeaud, Th.

1938 Javaans-Nederlands handwoordenboek. Groningen/Batavia: Wolters.

Poerbatjaraka, Lesya

1926 Agastya in de Archipel. Leiden: Brill. [PhD thesis Rijksuniversiteit Leiden.]

1927

'De dateering van het Oud-Jav, Rāmāyaṇa', in: Gedenkschrift uitgegeven ter gelegenheid van het 75-jarig bestaan op 4 juni 1926 [KITLV], pp. 265-72. 's-Gravenhage: Nijhoff.

'Het Oud-Javaansche Rāmāyana', Tijdschrift voor Indische Taals Landen Volkenkunde (TBG) 72:151-601. 
Pott, P.H.

1946 Yoga en Yantra in hunne beteekenis voor de Indische archaeologie. Leiden: Brill. [PhD thesis Rijksuniversiteit Leiden.]

1956 'The influence of Tantric Buddhism on ancient Indonesian civilization', Mārg 9:53-65.

1966 Yoga and Yantra; Their interrelation and their significance for Indian archaeology. The Hague: Nijhoff. [KITLV. Translation Series 8.]

Raffles, Th.S.

1817 The history of Java. London: Black, Parbury and Allen. 2 Vols.

Raghu Vira and Chikyo Yamamoto

1938 Rāmāyana in China. Nagpur: International Academy of Indian Culture. [Sarasvati Vihara Series 8.]

Rapporten Oudheidkundige Commissie

1902-1912 Rapporten Oudheidkundige Commissie van Nederlandsch-Indië voor oudheidkundig onderzoek op Java en Madoera. Batavia: Albrecht. [Bataviaasch Genootschap van Kunsten en Wetenschappen.]

Rapporten Oudheidkundige Dienst

1912-1915 Rapporten van de Oudheidkundigen Dienst in Nederlandsch-Indië. Batavia: Albrecht, 's-Gravenhage: Nijhoff.

Rassers, W.H.

1922

De Pandji-roman. Antwerpen: De Vos van Kleet. [PhD thesis Rijksuniversiteit Leiden.]

Raychaudhuri, Hemacandra

1920

Materials for the study of the early history of the Vaishnava sect. Calcutta: University of Calcutta. [Reprint 1975. New Delhi: Oriental Books Reprint Corporation.]

Reynolds, Frank E.

1991 'Rãmāyana, Rãma Jãaka, and Ramakien; A comparative study of Hindu and Buddhists traditions', in: P. Richman (ed.), Many Rāmāyanas; The diversity of a narrative tradition in South Asia, pp, 50-63, Berkeley: University of California Press.

Riederer, Josef 1994

'The goldsmith's techniques', in: W.H. Kal (ed.), Old Javanese gold (4th-15th century): an archaeometrical approach, pp. 46-58. Amsterdam: KIT-Tropenmuseum.

Romondt, V.R. van

1940 'De wederopbouw van den Çiwa-tempel te Prambanan', Djåwå 20:23440.

1952 'Pekerjaan membina kembali Candi Prambanan', Amerta: Berkala Arkeologi 1:37-43. [Reprint 1985.]

1954 'Een tempel komt tevoorschijn', Oriëntatie 46:665-73.

Rouffaer, G.P.

1918 'Oudheidkundige opmerkingen', Bijdragen tot de Taal-, Land-en Volkenkunde 74:138-66. 
Rowland, B.

1953

The art and architecture of India; Buddhist, Hindu, Jain. Baltimore: Penguin.

Saher, E. A. von

1900 De versierende kunsten in Nederlandsch Oost-Indië; Eenige Hindoemonumenten op Midden-Java. Haarlem: Bohn.

Santiko, Hariani

1987

Kedudukan bhatari Durgã di Jawa pada abad X-XV Masehi. [PhD thesis Universitas Indonesia.]

1990 'Kehidupan beragama golongan rsi di Jawa', in: Edi Sedyawati et al. (eds), Monumen; Karya persembahan untuk Prof.Dr. R. Soekmono, pp. 156-72. Depok: Fakultas Sastra, Universitas Indonesia.

Santoso, Soewito

1963

Lorodjonggrang (drama satu babak). N.p.: Balai Pustaka.

1980

Ramayana kakawin. New Delhi: International Academy of Indian Culture, Singapore: Institute of Southeast Asian Studies. [Sata-Pitaka Series Indo-Asian Literatures 251.]

1986

Krěșnāyana, the Krěsnạa legend in Indonesia. New Delhi: International Academy of Indian Culture. [Sata-Pitaka Series Indo-Asian Literatures 345.]

Saraswati, S.K.

1962 Early sculpture of Bengal. Second edition. Calcutta: Sambodhi.

Sarkar, H.B.

'The cultural contact between Java and Bengal', Indian Historical Quarterly 13:589-99.

1967 'The evolution of the Siva-Buddha cult in Java', Journal of Indian History 45:637-46.

1972 Corpus of the inscriptions of Java. Calcutta: Mukhopadhyay. 2 Vols.

1985 'The kings of Śri Śailam and the foundation of the Śailendra dynasty of Indonesia', Bijdragen tot de Taal-, Land-en Volkenkunde 141:323-38.

1989 'Rāmāyana in Javanese epigraphy, literary tradition and monumental art', in: D.P. Sinha and S. Sahai (eds), Rāmāyana traditions and national cultures in Asia, pp. 40-6. Lucknow: Directorate of Cultural Affairs, Government of Uttar Pradesh.

Sarkar, S.C.

1990

Studies in the common Jātaka and Avadāna tales. Calcutta: Sanskrit College.

Scheltema, J.F.

1912

Monumental Java. London: Macmillan.

Schlagintweit, E. de

1881 Le Bouddhisme au Tibet précédé d'un résume des précédents systèmes bouddhiques dans l'Inde. Lyon. [Annales du Musée Guimet III.] 
Schlegel, A.G. von

1829 Ramayana id est carmen epicum de Ramae rebus gestis poeta antiquissimi Valmicis opus [Libris Septem]. Bonneae ad Rhenum.

Schnitger, F.M.

1934 'Enkele oudheidkundige opmerkingen over het Tantrisme op Java', Bijdragen tot de Taal-, Land-en Volkenkunde 92:149-59.

Sedyawati (Hadimulyo), Edi

1973 'Serangkai relief tari pada Candi Lara Jonggrang', Musika; Brosur Ilmu Musik dan Koreografi. Jakarta: Dirjen Kebudayaan.

1978 'Kesatuan gaya seni arca antara Candi Rara Jonggrang dan Plaosan Lor'. Arkeologi 1-3:25-53.

1981 'The question of Indian influence on ancient Javanese dance', Review of Indonesian and Malaysian Affairs 16-2:59-83.

1985 Pengarcaan Ganeśa masa Kadiri dan Singasari; Sebuah tinjauan sejarah kesenian. [PhD thesis Universitas Indonesia.]

1986 'The devotional function of space arrangement; An observation on the Prambanan and Plaosan temples of Central Java', Paper International Seminar Cidakasa-Bhutakasa/Inner and Outer Space, Indira Gandhi National centre for the Arts, New Delhi, 20-26 November 1986.

1993 The dramatic principle of Javanese narrative temple reliefs', in: Ben Arps (ed.), Performance in Java and Bali; Studies of narrative, theatre, music and dance, pp. 174-85. London: School of Oriental and African Studies, University of London.

1994 Ganeśa statuary of the Kadiri and Sighasāri periods. Leiden: KITLV Press. [Verhandelingen 160.]

Smith, V.A.

1911 A history of fine art in India and Ceylon. Oxford. [Second edition, Oxford: Clarendon Press, 1930.1

Snodgrass, A.

1985

The symbolism of the stupa. Ithaca: Southeast Asia Program. Cornell University.

Soebadio, Haryati

1971

Jñānasiddhānta. The Hague: Nijhoff. [KITLV, Bibliotheca Indonesica 7.1

Soediman

1969

Chandi Laradjonggrang at a glance. Jogjakarta: Kanisius.

Soehamir

1948

A short guide to the Lara Djonggrang temples at Prambanan. Surakarta: Ministry of Education and Cultural Affairs, Republic of Indonesia.

1950 'The Lara Djonggrang temples at Prambanan', in: A short guide to the Borobudur and the Lara Djonggrang temples, pp. 23-48. Jogjakarta: Ministry of Education and Cultural Affairs, Republic of Indonesia. 
Soekmono, R.

1965 'Archaeology and Indonesian history', in: An introduction to Indonesian historiography, pp. 35-47. Ithaca: Comell University Press.

1967 'A geographical reconstruction of northeastern Central Java and the location of Medang', Indonesia 4:2-7.

1974 Candi; Fungsi dan pengertiannya. [PhD thesis Universitas Indonesia, Jakarta.]

1979 The archaeology of Central Java before 800 AD', in: R.B. Smith and W. Watson (eds), Early South East Asia; . Essays in archaeology, history and historical geography, pp. 457-73. New York/Kuala Lumpur: Oxford University Press.

1985 'Lumpur dalam konstruksi candi', in: Sulastin Sutrisno et al. (eds), Bahasa-sastra-budaya; Ratna manikam untaian persembahan kepada Prof. Dr. P.J. Zoetmulder, pp, 684-96. Yogyakarta: Gadjah Mada University Press.

1993 The candi as a cultural pusaka', in: H. Soebadio (ed.), Art of Indonesia, pp. 51-7. London: Tauris Parke.

Soenarto, Th.A.

1991 Candi Wisnu dahulu dan sekarang. Yogyakarta: Departemen Pendidikan dan Kebudayaan.

Stargardt, Janice

1992

'Water for courts or countryside; Archaeological evidence from Burma and Thailand reviewed, in: J. Rigg (ed.), The gift of water; Water management, cosmology and the state in South East Asia, pp. 59-72. London: School of Oriental and African Studies, University of London. 'Le cosmos, les ancêtres et le riz; L'eau dans l'espace urbain des Pyus en Birmanie', in: G. Condominas et al. (eds), Disciplines croisées; Hommage à Bernard Philippe Groslier, pp. 31 1-35. Paris: Éditions de l'École des Hautes Études en Sciences Sociales.

Stencel, R., F. Gifford and E. Moron

1976 'Astronomy and cosmology at Angkor Vat; Measurements of the temple are related to practical astronomy and religious symbolism', Science 193:281-7.

Stein Callenfels, P.V , van

1919 'De Rāmãyana-reliefs op den Çiwa-tempel te Prambanan'; 'De Krșñāreliefs op den Wisnoe-tempel', in: M. Lulius van Goor (ed.), Korte gids voor de tempelbouwvallen in de Prambanan-vlakte, het Diëng-plateau en Gedong Sanga, pp. 31-43. Weltevreden: Landsdrukkerij.

1922 'Een basrelie̊f van Prambanan', in: Verslag van het Tweede Congres van het Oostersch Genootschap, pp, 46-7. Leiden: Brill.

Stutley, M. and J. Stutley

A dictionary of Hinduism; Its mythology, folklore and development 1500 $B C-A D$ 1500. London: Routledge and Kegan Paul. 
Stutterheim, W.F.

1923 'Oudjavaansche kunst', Bijdragen tot de Taal-, Land-en Volkenkunde 79:323-46.

I925 Räma-legenden und Rāma-reliefs in Indonesien. München: Georg Müller. 2 Vols.

1926a De bouwvallen op den heuvel van Ratoe Baka bij Prambanan', Djăwå 6:129-36.

1926b Culturgeschiedenis van Java in beeld. Weltevreden: Kolff. [Java Instituut.]

1926c 'Oost-Java en de hemelberg', Djäwå 6:333-49.

1926d 'The story of ancient Java', Inter-Ocean 7-8:439-46.

1927 'Een belangrijke oorkonde uit de Kedoe', Tijdschrift voor Indische Taal-, Land-en Volkenkunde (TBG) 67:172-215.

1928a 'The temple ruins of Java', Inter-Ocean 9:685-9.

1928b 'De plaatsing der Rāma-reliefs van tjandi Lara-Djonggrang en de zonneomloop', Bijdragen tot de Taal-, Land-en Volkenkunde 84:118-31.

$1929 \mathrm{a}$ The meaning of the Kāla-Makara ornament', Indian Art and Letters (new series) $3: 27-52$.

1929b A Javanese period in Sumatran history. Surakarta: De Bliksem.

1929c 'Een bronzen schedelnap', Djåwå 9:14-5.

1930 Gids voor de oudheden van Soekoeh en Tjeta. Soerakarta: De Bliksem.

1931 'The meaning of the Hindu-Javanese candi', Journal of the American Oriental Society 51:1-16.

1932 'Oudheidkundige aanteekeningen', Bijdragen tot de Taal-, Land-en Volkenkunde 89:278-82.

1933 'Oudheidkundige aanteekeningen', Bijdragen tot de Taal-, Land- en Volkenkunde 90:267-99.

1935 'Een monografie over Tjandi Sadjiwan bij Jogjakarta', Djåwå 15:83-90. [Bookreview.]

1939 'Tets over prae-hinduistische bijzettingsgebruiken op Java', Mededelingen der Koninklijke Akademie van Wetenschappen, Afdeling Letterkunde, Nieuwe Reeks 2, 5:105-40.

1940 'De stichter der Prambanan tempels', Djăwå 20:218-33.

1989 Rāma-legends and Rāma-reliefs in Indonesia. New Delhi: Abhinav. [Translated from the German by C.D. Paliwal and R.P. Jain.]

Sugianti, Sri

1986 'Penafsiran mengenai relief Ramayana Candi Loro Jonggrang, Prambanan; Sanggahan atas Stutterheim dan Purbatjaraka', in: Pertemuan Ilmiah Arkeologi 4-IIb:529-49. Jakarta: Pusat Penelitian Arkeologi Nasional.

Suleiman, Satyawati

1976 Monuments of ancient Indonesia. Jakarta: Pusat Penelitian Purbakala dan Peninggalan Nasional.

1977 Concise ancient history of Indonesia. Second revised edition. Jakarta: Archaeological Foundation. 
Teeuw, A.

1990 Indonesisch-Nederlands woordenboek. Dordrecht: Foris. [KITLV.]

Teeuw, A. et al.

1969 Siwarätrikalpa of Mpu Tanakun; An Old Javanese poem, its Indian source and Balinese illustrations. The Hague: Nijhoff. [KITLV, Bibliotheca Indonesica 3.]

Temu

1993

'Temu evaluasi penelitian Wonoboyo', Berkala Arkeologi 13, Edisi khusus.

Tonnet, M.

1908 De godenbeelden aan den buitenmuur van den Çiwa-tempel te Tjand̦ Prambanan en de vermoedelijke leeftijd van die tempelgroep', Bijdragen tot de Taal-, Land-en Volkenkunde 60:128-49.

Treloar, F.E.

1972

'The use of mercury in metal ritual objects as a symbol of Śiva', Artibus Asiae 34:232-40.

Tuuk, H.N. van der

1897-1912 Kawi-Balineesch-Nederlandsch woordenboek. Batavia: Landsdrukkerij. 4 Vols.

Verslag

1926 Verslag van de Commissie van Advies inzake de restauratie der HindoeJavaansche Monumenten, nopens de reconstructie van den Ciwatempel te Prambanan. Weltevreden: Kolff.

Verslag Congres

1921-39 Verslag Congres van het Oostersch Genootschap. Leiden: Brill. Verwey, A.H.N.

1962 'A distant relative of the silver Mañjuśri from Ngemplak Semongan', Mededelingen van het Rijksmuseum voor Volkenkunde 15:132-47.

Vogel, J.Ph.

1911

Antiquities of Chamba state. Calcutta: Superintendent Government Press. [Archaeological Survey of India. New Imperial Series 36.]

1921 'Het eerste Rāma relief van Prambanan', Bijdragen tot de Taal-, Land- en Volkenkunde 77:202-15.

Vogler, E.B.

1949 De Monsterkop uit het omlijstingsornament van tempeldoorgangen en -nissen in de Hindoe-Javaanse Bouwkunst. Leiden: Brill.

1953 'Ontwikkeling van de gewijde bouwkunst in het hindoeïstische MiddenJava', Bijdragen tot de Taal-, Land-en Volkenkunde 109:249-72.

Voordracht

1925 'De voordracht van Dr. Bosch', Djåwå 5:162-6.

Voorhoeve, P. 1958

'Batakse buffelwichelarij', Bijdragen tot de Taal-, Land-en Volkenkunde 114:238-48. 
Walker, B.

1968

'Numbers', in: B. Walker, Hindu world, Vol. 2, pp. 136-7, London: Allen and Unwin.

Wayman, Alex

1987 'Esoteric Buddhism', in: Mircea Eliade (ed.), The encyclopedia of religion, Vol. 2, pp. 472-82. New York: Macmillan.

Wessing, R.

1991

'An enclosure in the Garden of Love', Journal of Southeast Asian Studies 22:1-15.

Williams, J.

1981

Wilson, H.H.

'The date of Barabudur in relation to other Central Javanese monuments'. in: L. Gomez and H.W. Woodward (eds), Barabudur; History and significance of a Buddhist monument, pp. 25-47. Berkeley: Asian Humanities Press. [Berkeley Buddhist Studies Series 2].

1840 Vishnu Purana; A system of Hindu mythology and tradition; Translated from the original Sanscrit and illustrated by notes derived chiefly from other Puranas, London: Murray.

Winter, C.F.

1839

'Oorsprong van de oudheden te Brambanan', Tijdschrift voor Neêrland's Indië 2, I:459-74; 2, II: 139-40.

Winter, C.F. and R. Ng. Ranggawarsita 1988

Kamus Kawi-Jawa; Menurut Kawi-Javaansch woordenboek. Yogyakarta: Gadjah Mada University Press. [First published in Dutch, 1879.]

With, K.

1920 Java: Brahmanische, Buddhistische und eigenlebige Architektur und Plastik auf Java. Hagen: Folkwang

Wolters, O.W.

History, culture, and region in Southeast Asian perspectives. Singapore: Institute of Southeast Asian Studies.

1979 'Studying Śrivijaya', Journal of the Malaysian Branch of the Royal Asiatic Society 52-2:1-32.

Uzerman. J.W.

1887 'Iets over de tempelruïnen van Prambanan', Verslagen en Mededeelingen Koninklijke Akademie van Wetenschappen, Derde Reeks 4:263-91.

1891 Beschrijving der oudheden nabij de grens der residentie's Soerakarta en Djogdjakarta. Batavia: Landsdrukkerij.

1903 'De Chalukyasche bouwstijl op den Diëng', in: Album Kern, pp.287-96. Leiden: Brill.

Zieseniss, A. 1963

The Rāma saga in Malaysia, its origin and development, Singapore: Malaysian Sociological Research Institute. [Originally published in German, Hamburg, 1928; translated by P.W. Burch.] 
Zoetmulder, P.J.

1982 Old Javanese-English dictionary. The Hague: Nijhoff. 2 Vols. 


\section{Index}

Abahayagiri order 22

Aceh 73

Ảdibuddha 26, 95

Agama 75, 103

Agastya 5, 77, 79-80, 103, 147-8, 158. 160

Aichele, W. $39-40,46-7,55-6,61,84-$ 5,98

amrta see holy water

amrtamanthana see Churning of the Milky Ocean

ancestor worship 35,48

Angkor Vat 93

animal sacrifice 125,134

animal skeleton, remains $47,70,119$, 124,130

añjalimudrã 82,84

Anom, 1.G.N. vii, 17, 76, 82, 86, 103. 113

aștadikpâla 48, 68, 88, 101-3

Auboyer, J. 209

Auster, P. i, 44

avatāra $36,88,95,137,162-3,167$. $170-1$

Baker, G. 13, 80

Bali, Balinese 43. 63, 81-2, 171-2. 208. 213,224

Bastin, J. 13

Batara, Bhațāra Guru 5, 146, 158-60

Baumgartner, A. 140

Behrend, T. 65

Bengal 41-3, 67, 93

Berlage, H.P. 176-7, 198

Bernet Kempers, A.J. vii, ix, 13, 16-7. 21-2, 39, 47, 52, 57, 61, 67, 74-6, $87,104-5,191-226$

Bhairava 72-3
Bhandarkar, R.G. 171-2

Bhattacharya, K. 11, 43, 69

Bhattacharya, S.K. 42, 100-1

Bhattacharyya, B. 82, 103

Bhattikāvya 29,97-9

binary opposition 74, 104

Blaaderen, L. van 86

blacksmithing 86

Blom, J.R. van $48,65,71-2$

bodhisattva $27,33,45,68,79,80-4,95$

body language 93

Boechari 39, 41, 54-5, 78, 107

Bonheur, A. Le 41, 45

Borobudur 29-30, 40, 67, 70, 74, 88$91,93,101-2,114-5,119,146,175$. $208,211,214,220,225$

Borobudur and Prambanan contrasted viii, $32,34,38,45,78,84,113-4$, 146

Bosboom, H.D.H. 13

Bosch, F.D.K, ix, 15-6, 21, 24, 30-5. $37-9,41,44,47-8,61-2,65,67,70$. $73-5,81-3,92,103,121,137,153-5$. $171,197-8,211$

Braginsky, V.I. 98

Brahmã 31, 33, 73, 79, 82, 95, 139 . $146,155,161,171-2$ statue $79,125,128,149-51,159$ temple $7,11,15-7,23,51,74,84$, $88-9,91,95-7,99,100,103,110$. $125,128,131,149,151,153-5$, $159,162,165-7,171,191,199$. 213,217

Brandes, J.L.A. 15, 27-8, 30-2, 34, 37 , $39,151,169,175,197$

Brockington, J.L. 93

Bronson, B. 19,24

Brumund, J.F.G. I1, 16, 26, 79-80. 
87,131

Bubrah (temple) $32,41,84$

Buddhism, Buddhist 15, 27, 30-2, 34 , $39,41,74,85,98-9,104,113-4$,

$119,161,210$

Burma, Burmese 22, 42

Buurman, P. 55, 86

Cambodia $64,69,93$

candi (defined) 9,20

Candi (specific temple)

A $7,17,130,157,213$

apit $7,17,74,87,103,153,159$,

$176,193,196-8,203,205-6,211-$ $4,217,219$

B $7,17,71,130,151,157,213$

Badut 158, 195

Bima 209-10

Gebang 200

Ijo 158

Jawi 220

Kalasan 13, 20, 111, 148, 206-7. $210,212,214,223$

kelir $5,67-8$

Kidul 195

Merak 158, 195

Nandi $7,17,71,129,131,150,157$. 213

perwara $47,53,83,88,196$

Plaosan $38-9,41,77,79,82,113-4$, $220,225-6$

Sambisari $45,73,78,82,114$

Sari $111,215,220$

Sewu 11, 13, 31-2, 41-2, 44-5, 74 , $81-4,86,92,95,103-5,110-4$. $148,195,200,212,221$

Sojiwan $65,71-4,82,113-4$

Sumbemanas 158

vahana $7,17,64-5,157,193$

Wukir 195

Candra 7, 151, 172

capital city 19,63

Casparis, J.G. de 13, 22-5, 38-41, 45, 53-5, 84

Central Javanese

ant $27-8,30,32,34-5,45,77-8,86$. $93,114-5,159,203$

period $27,43,52,61,70,73,84$,
159,171

Cephas, Kasian 112, 135, 151

Champa 75

Chandra, Lokesh 22, 47, 69, 103

China, Chinese 22, 36, 69, 73, 99, 124 . 133

Christie, J. Wisseman 51

'Churning of the Milky Ocean' 45-59, 141,170

'classical' $3,78,90,115$

Coèdes, G. 15, 22-3, 69

coexistence $26,40,44-5,113,119$

Cohn, W. 208

Colebrooke, H.T. $36,70,132,134$

Coleman, Ch. 46, 70, 134

Colless, B. 22-3

Coolwijk, P.H. van 176, 198

Coomaraswamy, Ananda K. 96, 209

Comelius, H.C. 13, 197

'cosmicization' 55

course of the sun 90-1, 93, 161-73

Cowell, E.B. 99

Crawfurd, J. 11, 13-4, 23, 26, 151

Damais, L.-Ch. $24,39-40$

dating $23-5,31,34,37-9,45-6,73-4$, $78,83,98,113-4,196$

degeneration, decadence of art 27,31. 39

design $3,5,7,18,28,45,51,53-4,61$ $3,69,78,81,83,90-2,103,161$

discovery $13-4$

Döhring, K. 173

drainage $18,51-2,57-9$

Drewes, G.W.J. 170

Dumarçay, J. vii, 25, 29, 38-9, 68, 756,83

Durga $5,12-3,32,36,77,79-80,87-8$, $147-8,158-60,197$

Dutt, N. 42

dvārapāla 13,80

Dwiyanto, Djoko 40

East Javanese

art $27-8,30-5,77-8,115,220$

period $27,43,70,72,77,119$

style $37,78,99,114,169$

Echols, J.M. 54 
Eerde, J.C. van 19-20, 45, 63

eight (octad) 68-9, 103

Eliade, M. 54-5

Ensink, J. 38, 44

Erp, A.Th. van 85

Erp, Th. van 7, 14-6, 30, 37-8, 64-5. $76,85,105,109-10,112,115,151-$ $2,175-6,181,197-8,208,212,214$ 5

excavation $13-4,21,26,63,76-7,80$, $119-23,126,132$

Fontein, J. vii, 15, 39, 45, 74, 90-1, 93, 96-101

Friederich, R. 80, 134

funerary function 34,38

monument 35,172

theory $20-1,36-7,47,73,119$

Ganeśa $5,13,36,77,79,88,147-8$, 158-9

Garbe, R. 142

Garuda 7, 17, 135, 142, 157, 162, 193

Gaựivișaya 41-2

geometrical centre $66-7,194,213$

Gericke, J.F.C. 54

Ghosh, Mallar 42

Gifford, F. 93

Gomez, L. 43

Gonda, J. 89-90, 101

Goris, R. 171-2

Goudriaan, T. 74

government see kraton

Grobogan area 20-2

Groneman, J. 9, 14-6, 26, 45, 93, 95, $102,105,112,135-8,151,178,184$. 197, 217

Grünwedel, A. 73

Gupta, S. 74

Haan, B. de ix, 17, 105, 111, 157-60, $165,167,176,198-9$

Hansen, B. 57

Hardjowardono, Pitono 12, 63

Heine-Geldern, R. von 46, 51, 67, 195

Helfritz, H. 9, 11, 38, 77

hikayat 29, 89, 99
Hikayat Sĕri Rama 89

Hinayāna 73

Hindu, Hinduism $32,36,46,48,61-2$, $65,76-7,82,84$

Hinlopen Labberton, D, van 196

Hoekstra, P. 58

Hoens, D.J. 74

Hoepermans, N.W. 151

Hoëvell, W.R. van 132

Holt, C, 24, 39, 77

holy water $49,51,54,56,61,88,142$. 172

Hoogmoed, W. 52

Hoop, A.N.J. Thomassen a Thuessink van der 221

Hsüan-tsang (Xuanzang) 69, 73, 133

human sacrifice $14,70-3,130$

human skeleton $14,47,70-3,130$

Huntington, S. 42

I-ching (Ijing) 69

imperfections (technical) 80, 147

inauguration $17,24-5,39-40,72$

India, Indian 29, 34-5, 42-3, 61, 64, 67. $69,72,75,77-8,82,88-90,92,95$. $98,100,104,115,130,132,135$, $137,143,146,161,163,171-2,208-$ 11, 220

Indonesian

Archaeological Service (Dinas Purbakala) $18,73,76$

independence $17,37,75,88,98,195$

inscription

Kedu 35

Kelurak $32-4,41-4,81-2,84$

Loro Jonggrang 24-5, 39-40, 49. 53 . 55

Old Javanese 24

Śailendra 25

Wanua Tengah III 40

Japanese $17,81-2,103$

Java Instituut 30-1

Javanese $29-30,61,64-5,67,71,85$, $89-90,92-3,112,114-5,145,148$, $163,200$.

Jochim, E.F. 73, 79-80, 83, 152

Jordaan, R.E. 14, 24-6, 37-8, 40-1, 43 , 
$49,51-2,56-7,59,63,70,72,74$. $87,101,103,112,114$

Juynboll, Th.W. 193

kãla 49-50, 87, 109, 158, 160, 186, $203,213,216-7,219-21,224$

Kāli $70,130,134$

Kalidasa 97, 140-1, 144-5

Kãpālika 11, 70-4

Karmavibhanga 89-91

Kat Angelino, P. de 172

Kats, J. 96, 99, 171, 217

Kedah $48,98,119$

Kern, H. II, 36, 44, 69, 73, 95-6, 216

Khanna, Amar Nath 42

Khanna, Vinod 97

king

Balitung 36, 38, 40, 196

Chulalongkorn II 15

Dakșa 28, 31-2, 36, 38

Dharmapāla 42

Harșavardhana $35,171-2$

Śri Sanggrāmadhanamjaya 33

Klokke, M.J. 51

Knebel, J. 152

Kompas 23, 45

Kramrisch, Stella 5I, 62, 67, 195, 2089. 211,220

kraton $19-23,45,65,85$

transfer from Central to East Java 20. $73-4,78,114,196$

Krom, N.J. vii, ix, 12, 16, 19-21, 23-4, $27-8,30,32,34,36-8,51-2,61,63$, $70-1,73,75,78,80,85,88,91,93$, $95,102,109-10,112,147-53,163$. $170-1,193,196,201,205,210,214$. 225

Krșna 7, 15, 42, 88, 95-6, 100-1, 104, $153,170-1,217$

Kuntara Wiryamartana 92

Kusen 82, 83, 86

Lalitavistara 90, 146

Lamb, A. 48,119

Lanka 49, 91, 141, 165-6, 217

Laos 99

Laporan 59

Leemans, C. $13,26,54,80,132$
Lévi, S, 99

Liebert, G. 82, 104

Lillie, A. 133

linga 7, 22, 45, 56, 125, 132, 158, 160

Lohuizen-de Leeuw, J.E. van 25,42 , $101-3,110$

lokapāla $7,27,46,101,103$

Lons, C.A. 13, 151

Lorenzen, D.N. 72, 73

Loro Jonggrang (name) 5, 12

Lulius van Goor, M. 19, 23, 76, 100 , $138,152,193$

Lumbung (temple) $32-3,41,84$

Mabbett, I.W. 46, 111-2

Mackenzie, C. 11, 13, 16, 26, 80, 151

Mahäbhärata 98-9, 133, 140, 142, 171

Mahākāla 5, 149, 214

Mahãyāna 3, 22, 28, 31, 34, 38, 43, 70, $73,95-6$

Maheśvara see Ś̉iva

Mahișāsuramardinî 5, 148

main

entrance 19,64

temple chamber 5

makara 79, 109-10, 148, 203, 213, 217. 219, 221

Malay, Malaysia 47, 89, 93, 98, 119 , 163

Mānasāra 65, 67

mandala $33,73,81-4,87-8,103$

Mandara, Mount 46, 48

Mañjuśrĩ $33,41,43-4,73,81-4,86$. 112

Manu 141

marl theory 37-8

Martowikrido, Wahyono 23

Mataram 20-1, 134, 197

mausoleum 20,36, 38, 45-6, 119

Mendang Kemulan 12, 20-2

Mendut (temple) 177

Merapi, Mount $11,19,22,64$

Merbabu, Mount 22

Meru, Mount 45-7, 110, 112, 208

metaphor 56,98

Miksic, J. 9, 38, 41

Mitchell, G. vii

Moens, J.L. $30-3,36,41,70,74,114$ 